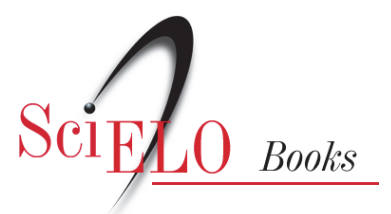

\title{
Relações sociais e ética
}

\author{
Maria da Graça Correa Jacques \\ Maria Lucia Tiellet Nunes \\ Nara Maria Guazzelli Bernardes \\ Pedrinho A. Guareschi \\ orgs.
}

JACQUES, MGC., et al. org. Relações sociais e ética [online]. Rio de Janeiro: Centro Edelstein de Pesquisas Sociais, 2008. 210 p. ISBN: 978-85-99662-89-2. Available from SciELO Books <http://books.scielo.org $>$.

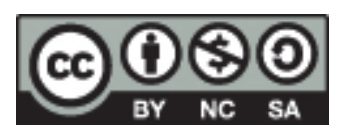

All the contents of this chapter, except where otherwise noted, is licensed under a Creative Commons Attribution-Non Commercial-ShareAlike 3.0 Unported.

Todo o conteúdo deste capítulo, exceto quando houver ressalva, é publicado sob a licença Creative Commons Atribuição Uso Não Comercial - Partilha nos Mesmos Termos 3.0 Não adaptada.

Todo el contenido de este capítulo, excepto donde se indique lo contrario, está bajo licencia de la licencia Creative Commons Reconocimento-NoComercial-CompartirIgual 3.0 Unported. 


\section{BIBLIOTECA VIRTUAL DE CIÊNCIAS HUMANAS}

\section{RELAÇõES SOCIAIS E ÉTICA}

Maria da Graça Correa Jacques Maria Lucia Tiellet Nunes Nara Maria Guazzelli Bernardes Pedrinho A. Guareschi Organizadores 


\section{Maria da Graça Correa Jacques}

Maria Lucia Tiellet Nunes

Nara Maria Guazzelli Bernardes

Pedrinho A. Guareschi

Organizadores
Esta publicação é parte da Biblioteca Virtual de Ciências Humanas do Centro Edelstein de Pesquisas Sociais - www.bvce.org

Copyright (c) 2008, Maria da Graça Correa Jacques; Maria Lucia Tiellet Nunes; Nara Maria Guazzelli Bernardes; Pedrinho A. Guareschi

Copyright (c) 2008 desta edição on-line: Centro Edelstein de Pesquisas Sociais Ano da última edição: 1995

Nenhuma parte desta publicação pode ser reproduzida ou transmitida por qualquer meio de comunicação para uso comercial sem a permissão escrita dos proprietários dos direitos autorais. A publicação ou partes dela podem ser reproduzidas para propósito não comercial na medida em que a origem da publicação, assim como seus autores, seja reconhecida.

ISBN 978-85-99662-89-2

Centro Edelstein de Pesquisas Sociais

www.centroedelstein.org.br

Rua Visconde de Pirajá, 330/1205

Ipanema - Rio de Janeiro - RJ

CEP: 22410-000. Brasil

Contato: bvce@centroedelstein.org.br

Rio de Janeiro

2008 


\section{Sumário}

Apresentação 1

Silvia T. Maurer Lane

Introdução 3

Ética e relações sociais entre o existente e o possível . 6 Pedrinho A. Guareschi

Acerca da ética e da perspectiva interdisciplinar 12

Tania Mara Galli Fonseca

Ética e relações sociais um enfoque filosófico

Maria Teresinha Abs da Cruz de Agosto

A terra e o equilíbrio humano

Ivo Poletto

Trabalho e tempo livre: uma abordagem crítica .

Paulo Valério Ribeiro Maya

Doença dos nervos: o ser trabalhador como definidor da identidade psicológica.

Maria da Graça Corrêa Jacques

$O$ trabalho de iniciação científica e o sistema de produção capitalista: um paralelo entre a atividade de bolsista e o sistema de fábrica

Ana Cristina Garcia Dias e Carla Dalbosco

Saúde mental e trabalho: reflexões a partir de estudos com trabalhadores afastados do trabalho por adoecimento profissional .... 70

Jaqueline Tittoni e Henrique Caetano Nardi
Intervenção em um grupo de trabalhadores em processamento de dados

Lucia Bertini e Guilene Salerno

Zero hora prega o extermínio de espécies - a ideologia nos meios de comunicação de massa...

Marcos de Oliveira Muller

IURD: religião, poder e dominação

Fátima O. de Oliveira e Graziela C. Werba

Apontamentos para uma análise institucional da universidade.

Paulo Roberto de Carvalho

Uma abordagem estratégica no planejamento de grupos: o método Altadir de planejamento popular — MAPP

Jáckson De Toni, Guilene Salerno e Lúcia Bertini

Psicodramatizando a construção da cidadania: o ser criança e adolescente em um centro de comunidade

Sissi Malta Neves

Pedagogia materna e relações sociais.

Silvia Zanatta Da Ros

Revisitando a educação popular a partir das mulheres Papeleiras ....171 Nilton Bueno Fischer e Alcindo Antônio Feria

Das crises e dos desafios 
Ser mulher, ser homem: significações construídas por crianças de classes populares

Nara M.G. Bernardes, Helena Beatriz Scarparo, Ana Helena P. do Amarante e Volnei S. Matias

Anotações sobre ética, movimentos sociais, pesquisas

Petronilha Beatriz Gonçalves e Silva

\section{Possíveis intervenções psicossociais em relação aos portadores de} fissuras lábio-palatais

Maria Lucia Tiellet Nunes e Marcia Luconi Viana

\section{Apresentação}

Silvia T. Maurer Lane

O V Encontro Regional da ABRAPSO (Associação Brasileira de Psicologia Social) reafirma o acerto da criação desta Associação, como uma necessidade da comunidade científica para a pesquisa e a reflexão sobre nossa realidade e o ser humano que a constitui em toda a extensão do nosso território.

Semelhanças e diferenças vêm emergindo nas investigações realizadas de norte a sul. Consciência, Atividade, Identidade, Afetividade - categorias fundamentais na constituição do psiquismo humano - vêm sendo objetos de pesquisa nos diversos centros universitários que se dedicam ao desenvolvimento de uma Psicologia Social Crítica.

A redescoberta das emoções como mediações, tão importantes como a linguagem e o pensamento, está nos levando a investigar como se formam os nossos valores (bom-mau, feio-bonito), e assim contribuir científica e praticamente para o desenvolvimento de consciências, ações, enfim de pessoas que vivam com mais dignidade e com realizações existenciais mais plenas. Estamos procurando conhecer como se constituem estes valores, de início individuais, mas que se transformam histórica e socialmente numa Ética.

E Ética é o tema central deste livro, sob a ótica de uma Psicologia Social Crítica.

Em um primeiro momento, ela é enfocada em sua origem filosófica - com seus fundamentos teóricos, suas implicações interdisciplinares, e suas consequências no cotidiano.

$\mathrm{Na}$ II Parte, os artigos tratam do aspecto mais fundamental do ser humano - o trabalho - e suas decorrências como o lazer, a identidade, a saúde física e mental.

A III Parte analisa um dos fatores responsáveis pelo processo histórico de hominização - a comunicação — seja ela de massas (jornal), institucional (igrejas), ou individual. 
Na IV Parte discutem-se experiências concretas de intervenção social. É aqui que a teoria é testada e as contradições são enfocadas com crítica e coragem.

$\mathrm{Na} V$ Parte examina-se a decorrência mais importante dos valores morais e éticos - a problematização das diferenças sociais, ou seja, a contribuição para uma sociedade mais verdadeiramente democrática e pluralista.

Boa leitura e profunda reflexão.

\section{Introdução}

Nos dias 6 a 8 de julho de 1994 realizou-se, em Porto Alegre, na PUCRS, o V Encontro Regional da ABRAPSO (Associação Brasileira de Psicologia Social). Foram dias de reflexão e discussão, onde mais de 100 pessoas, de vários estados do sul do Brasil, debateram diversos problemas referentes à problemática ética das relações sociais. Após o encontro, acharam os participantes que seria importante e necessário divulgar algumas contribuições que se constituíram em momentos de reflexão somando-se ao coro de milhões de brasileiros que procuram construir uma sociedade mais justa e solidária.

$\mathrm{O}$ presente volume tem, pois, sua origem na partilha desses questionamentos e inquietações. E como um estuário de dezenas de contribuições advindas da participação de muitos. O que mais nos provocou foi a conviç̧ão generalizada de que não é suficiente saber, mas que é necessário modificar, transformar, colocar em prática o que se discutiu. Como afirma Aristóteles, em sua Ética a Nicômacos (II, 2, 1103 b 26-30): "não é para saber o que é a virtude em sua essência que esse estudo foi empreendido, mas para tornar-nos virtuosos". O que importa é a concretização e a prática.

Os trabalhos que seguem fundamentam-se nessas considerações básicas. Dos 52 trabalhos apresentados, foram selecionados 20, e agrupados em cinco grandes temas:

\section{Tematizações teóricas gerais}

Quatro trabalhos discutem o que poderíamos chamar de considerações teóricas. Pedrinho Guareschi discute os fundamentos da ética, mostrando que são as relações seu objeto central, traçando as distinções entre ética e moral. Tânia Galli Fonseca traz uma perspectiva interdisciplinar da ética e das relações sociais. Terezinha D'Agosto faz uma abordagem filosófica dessa problemática. Ivo Poletto mostra a ética presente no relacionamento com nosso Planeta Terra e suas consequências para o equilíbrio humano. 


\section{II. Ética e Trabalho Humano}

Cinco abordagens analisam esse tema central: Paulo Valério Maya discute as estratégias de apropriação do tempo livre, mostrando como esse espaço é sempre mais ligado e legitimado em função da apropriação do trabalho. Maria da Graça Jacques analisa as relações de trabalho como centrais na definição da identidade do trabalhador. Ana Dias e Carla Dalbosco traçam um paralelo entre a atividade dos bolsistas de iniciação científica e o sistema de fábrica do modo de produção capitalista. Jaqueline Tittoni e Henrique Nardi traçam a relação que se estabelece entre saúde mental e trabalho dentro da temática da existência humana e de sua realização. Lúcia Bertini e Guilene Salerno relatam uma intervenção realizada entre trabalhadores no setor de processamento de dados.

\section{III. Ética, Meios de Comunicação e Ideologia}

Três trabalhos tematizam essa problemática. Marcos de Oliveira Muller, em Zero Hora prega o extermínio de espécies - A Ideologia nos meios de comunicação de massa, discute o papel de um grande jornal na estigmatização de determinados grupos humanos, mostrando como se constroem (e se reproduzem) representações sociais valorativas sobre segmentos que podem trazer questionamentos ao grupo ou à ideologia dominante. Um segundo estudo, de Graziela Werba e Fátima Oliveira, IURD: Religião, Poder e Dominação, analisa como a comunicação é empregada por determinados grupos religiosos no sentido de criar e reproduzir relações de dominação. Finalmente, Paulo Roberto de Carvalho faz uma análise institucional da Universidade, especialmente a maneira como se instituem relações de poder.

\section{IV. Ética e Intervenção Social}

Quatro estudos narram estratégias concretas de intervenção na linha de transformação das relações sociais. Jáckson De Toni, Guilene Salerno e Lúcia Bertini apresentam e discutem a aplicabilidade do Método Altadir de Planejamento Popular (MAPP) e a partir de experiências realizadas em Porto Alegre, mostram como a participação pode ser uma realidade nos dias de hoje. Sissi Malta Neves traz a experiência de meninos e meninas em situação de risco, apontando como se pode resgatar ou construir a cidadania entre crianças e adolescentes num Centro de Comunidade através do método do Psicodrama. Sílvia Zanatta Da Ros nos leva para dentro da trama da relação entre o papel educativo da mãe e o mundo social: como se relaciona a pedagogia materna com a complexa realidade das relações sociais? Nilton Fisher narra a experiência da Associação de Papeleiras de Porto Alegre, nas particularidades e nuanças de quem participa dos dramas e dilemas da sobrevivência.

\section{V. Ética e Problematização das Diferenças}

Finalmente, numa quinta seção, são apresentados quatro trabalhos mostrando as dificuldades que surgem quando se pretende construir uma sociedade verdadeiramente democrática e pluralista, que respeite as diferenças e particularidades dos diversos atores e grupos sociais. Nilza da Rosa Silva traz um estudo com pessoas da terceira idade, onde se faz uma análise a partir da dimensão processual da subjetividade. Nara Bernardes, em Ser homem/ser mulher: significações construídas por meninos $e$ meninas de classes populares, analisa as relações entre raça, gênero e classe e aponta para possíveis superações de assimetrias sociais. Petronilha Gonçalves e Silva, especificamente dentro das relações raciais, discute os pressupostos silenciosos que perpassam o cotidiano social. Finalmente, Maria Lucia Tiellet Nunes, a partir duma abordagem psicossocial, apresenta diversos modos de intervenção para superar o estigma da fissura.

Aproveitamos para agradecer o grande apoio prestado pela PUCRS, através do Instituto de Psicologia, e pela FAPERGS para a realização do evento. Além disso, por todo um semestre o grupo de estudos sobre Ideologia, Comunicação e Representações Sociais, coordenado pelo Prof. Pedrinho A. Guareschi, se debruçou sobre os textos, contactando os autores e concretizando esse empreendimento.

O material é abundante e rico. Pensamos, com isso, estar contribuindo, dentro de nossas possibilidades, na construção de um sociedade igualitária e democrática, onde as relações sejam verdadeiramente justas, isto é, éticas.

Os organizadores 


\section{Ética e relações sociais entre o existente e o possível}

Pedrinho A. Guareschi

PUCRS

Estas são algumas considerações preliminares aos diversos trabalhos que estão sendo apresentados neste livro. A escolha do tema deveu-se à análise das urgências sociais que se manifestaram em nossa sociedade nos últimos tempos. Vivemos uma situação social onde se constata uma enorme lacuna: a dimensão ética está praticamente ausente das decisões políticas, culturais e sociais. Há um vazio ético que ameaça corroer a alma nacional. Os escândalos e as situações constrangedoras em que se vê envolvida grande parte dos responsáveis pela coordenação nacional, obriga os cientistas sociais a se voltarem, urgentemente, para a análise e discussão desses problemas urgentes. Essa a razão da escolha dessa temática a ser discutida no V Encontro Regional da Abrapso.

Assumimos aqui o Ser Humano como sujeito de relações, não como algo pronto, mas como em contínua construção. Ser humano significa, de fato, tornar-se humano, conquistar-se. A subjetividade humana é o resultado de milhões de relações. Recortamos, do universo dos milhares e milhões de relações que estabelecemos, parcelas específicas, diferenciadas e, com isso, construímos nossa subjetividade. Por isso mesmo, somos absolutamente singulares, únicos, irrepetíveis, pessoais (pessoa = relação). Somos como que o ancoradouro de milhões de experiências, naus dispersas num imenso universo que um dia aportaram em nosso pequeno porto. E na medida em que tomamos consciência do que fizeram de nós, nos libertamos, pois é a verdade que liberta. E na medida em que somos conscientes e livres, somos responsáveis.

Esse sujeito humano, singular e responsável, é também um sujeito ético, individual e social. Somos sujeitos pessoais, únicos, irrepetíveis e responsáveis por nossos atos; ao mesmo tempo, e no mesmo nível de profundidade, o sujeito pessoal comporta a dimensão social: somos ontológica e biologicamente sociáveis, seres políticos, feitos para a convivência. Essa a lição de Aristóteles: "Um homem incapaz de integrarse numa comunidade, ou que seja autossuficiente a ponto de não ter necessidade de fazê-lo, não é parte de uma cidade, por ser um animal selvagem ou um deus". ${ }^{1}$ A ética, portanto, é individual e social ao mesmo tempo. Ninguém é ético para si; somos éticos em relação aos outros e em relação à distribuição e posse dos bens materiais.

Essa consideração nos leva um passo adiante: qual o centro da ética? É o próprio Aristóteles que nos diz que a justiça é a virtude central da ética, pois ela comanda os atos de todas as virtudes.

Esta forma de justiça não é parte da virtude, mas a virtude inteira e seu contrário, a injustiça, também não é uma parte do vício, mas o vício inteiro.

Ainda:

Essa forma de justiça (geral) é, portanto, uma virtude completa e governa nossas relações com os outros; por isso, muitas vezes, a justiça é considerada a virtude mais perfeita e nem a estrela vespertina, nem a estrela matutina é mais admirada que ela. Daí o provérbio: a justiça encerra toda a virtude. ${ }^{3}$

É esse tripé — ser humano, ética, justiça — que está em jogo quando queremos discutir ética e relações sociais: o ser humano como relação e sujeito da ética, a ética como ética das relações e relações sociais que sejam justas (justiça).

Esse tripé é, na verdade, inseparável. No momento em que falamos em ser humano, o entendemos como um ser humano resultado de milhões de relações. Esse ser humano é sempre pessoal e socialmente ético. Quando falamos de ética, falamos de ética de relações, pois é somente às relações (conosco, com os outros seres humanos, com a natureza) que se pode aplicar o adjetivo ético; um ser humano é ético por que as relações que ele estabelece são éticas. Não existe, é incompreensível o puro indivíduo, isolado e separado de tudo. Nós nos fazemos e nos constituímos através de relações, e a essas relações se atribui especificamente o adjetivo ético. Alguém é ético ou antiético se age bem ou mal em relação a algo ou a alguém.

\footnotetext{
${ }^{1}$ In Pegoraro, O. Ética e Subjetividade: ética pessoal e social à luz da justiça. Centro de Ética e Política, UFRJ, RJ, 1993: p.6 (mimeo).

${ }^{2}$ Aristóteles, op.cit. V,3, 1130 a 9-12.

${ }^{3}$ Aristóteles, Ética a Nicômacos V, 3, 1130 b 26-29 - 1131 a 1-4.
} 
O passo mais difícil, e mais obscurecido e negado, muitas vezes propositadamente, é a ligação entre ética e justiça. Há um elo necessário, inseparável, entre essas duas realidades. Já começa pelo fato de que justiça é uma relação. Ninguém é justo sozinho. Somos justos quando estabelecemos e quando passam a existir relações justas, igualitárias, entre dois seres. A ideia de que existe alguém que pode ser justo sozinho é uma fantasia do individualismo, fundamentada na ideologização liberal de um ser humano separado de todo o resto, absoluto (que para Aristóteles é ou um animal, ou um deus).

A justiça tem a ver, pois, com relações. Justiça, no dizer de J. Rawls, ${ }^{4}$ é um princípio fundador, fundamentado em duas premissas:

1. Cada pessoa deve ter direito ao sistema total mais amplo de liberdades iguais básicas compatível com um sistema similar de liberdade para todos.

2. As desigualdades sociais e econômicas devem ser estruturadas de tal modo que sejam, ao mesmo tempo, para o máximo proveito dos menos favorecidos, nos limites de um justo princípio de poupança, e ligadas a cargos e posições acessíveis a todos, sob condições de uma justa igualdade de oportunidade.

O primeiro é o princípio da liberdade; o segundo é o da diferença.

É importante distinguir aqui entre Ética e Moral. Em psicologia e ciências afins são conhecidos os estudos de Kohlberg ${ }^{5}$ e Piaget $^{6}$ (1932) sobre desenvolvimento moral.

Kohlberg distingue seis estágios de desenvolvimento moral, dentro de três níveis:

1. No nível pré-condicional, a criança é primariamente influenciada pelas consequências do que ela faz. Há dois graus: a criança obedece porque os adultos são poderosos e podem castigar os que se comportam mal

\footnotetext{
${ }^{4}$ Rawls, J. (1981). Teoria da Justiça. Brasília: Editora Universidade de Brasília.
}

${ }^{5}$ Kohlberg. L. (1966) "A cognitive-developmental analysis of children's sex-role concepts and attitudes", in The Development of sex-differences, ed. por E.E. Maccoby. Stanford: Stanford University Press.

Idem(1969) “A cognitive-developmental approach to socialization". In Handbook of socialization. ed. por D.Goslin. Chicago: Rand-McNally.

${ }^{6}$ Piaget, J. (1932) Moral Judgment of the Child. Glencoe: Ill: Free Pess. (primeiro estágio), ou a criança tenta obter satisfação de necessidades de tal modo que ela consiga recompensas (segundo estágio).

2. No nível convencional, uma criança mais crescida torna-se consciente e interessada no que esperam dela e tenta comportar-se de maneira tal que possa ir ao encontro dessas expectativas. Temos aqui mais dois estágios: há um desejo de ser um bom menino ou menina, de modo que os outros possam aprovar nossa conduta (terceiro estágio), e há o desenvolvimento da noção de se cumprir com a obrigação, respeitar a autoridade e preservar a ordem social, pois tais coisas são tidas como certas e corretas (quarto estágio).

3. No nível pós-convencional, à medida em que a pessoa amadurece, orienta-se para valores morais abstratos e para o que ela pessoalmente achar correto. Os dois últimos estágios são: a pessoa começa a pensar sobre os direitos dos outros, o bem comum e as leis adotadas pela maioria (quinto estágio), e os padrões de justiça escolhidos pela pessoa e sua própria consciência têm mais influência no seu comportamento do que as regras e leis existentes na sociedade (sexto estágio).

Como se vê na análise desses três níveis, o desenvolvimento moral

começa com um egocentrismo fechado (anomia), passando por uma identificação ético-psicológica com a sociedade, aceitando-se acriticamente os critérios éticos estabelecidos (heteronomia e socionomia), até chegar a uma motivação ética baseada nos princípios de justiça que permitem julgar a própria sociedade (autonomia).

Nesse desenvolvimento podemos visualizar a passagem de um comportamento moral, para um comportamento ético. A moral se coloca principalmente na heteronomia e socionomia, onde os determinantes são ainda externos. No dizer de Mifsud, "o juízo moral se baseia sobre os princípios de justiça ou de imparcialidade. O desenvolvimento moral consiste no equilíbrio gradual das estruturas do 'roletaking' e dos princípios de justiça". E entende justiça

no sentido de uma resolução moral entre reclamações divergentes, isto é, uma referência a um método para distribuir ou definir

${ }^{7}$ Tony Mifsud 1981. "Una perspectiva psicológica del juicio moral: Lawrence Kohlberg Teologia y Vida, XXII, n. 2, p.159. 
reclamações. A regra básica da justiça é a igualdade distributiva: tratar cada homem de modo igual. ${ }^{8}$

A justiça permanece, pois, como sendo o centro de toda fundamentação ética.

A justiça se entende, pois, desde os que sofrem injustiça, pois sendo a justiça uma relação que tem a ver com igualdade, respeito, direitos iguais etc. é normalmente e naturalmente a partir dos que estão privados e faltantes desses bens e direitos que se pode começar a pensar em restabelecimento dessas lacunas. Como bem diz Mifsud

... não estamos de acordo se se limita o princípio de justiça a assumir a perspectiva de todos. Seria mais justo dizer que o princípio de justiça implica a perspectiva dos que estão em desvantagem... A justiça pertence à esfera ética enquanto princípio de opção, mas também à esfera metaética enquanto implica um 'para onde' de uma cosmovisão. ${ }^{9}$

Dussel, principalmente em sua obra "Ética Comunitária. Liberta o pobre!"10 faz uma distinção entre ética e moral, ou moralidade. Moral, ou moralidade, para ele indicam o sistema ou a ordem estabelecidos no poder. Já ético, ou eticidade, se referem à ordem futura, à transformação das estruturas vigentes, e à libertação de toda estrutura de injustiça. Nesse sentido, o moral, isto é, a ordem estabelecida, muitas vezes não é ético, e vice-versa. Se confrontarmos essa acepção de Dussel com a concepção de Kohlberg, vemos que ela pode nos ajudar a compreender e a solucionar diversos problemas que porventura possam aparecer. No segundo nível de Kohlberg, o convencional, a pessoa se identifica com a sociedade e assume seu ponto de vista. $\mathrm{O}$ moral é responder às expectativas da família, do grupo ou do país, independentemente das consequências que daí possam advir. Se as relações, dentro desse país ou grupo, são relações assimétricas, de injustiça, a pessoa pensa agir moralmente reproduzindo tais relações. Tal situação não poderia, contudo, ser qualificada como ética.

${ }^{8}$ Mifsud, Tony. Desarrollo moral según Lawrence Kohlberg: exposición y valorización desde la ética cristiana. Tese de doutoramento. Fac. de Teologia, Univ. Pontifícia de Comillas, Madrid, 1980, p.50.

${ }^{9}$ Idem, pg. 55-56.

${ }^{10}$ Dussel, E. (1986) Petrópolis: Vozes.
Poderíamos perguntar para concluir: haveria algum critério que nos pudesse orientar num sentido de termos mais garantia e segurança de que na realidade estamos no caminho da ética, e não apenas reproduzindo uma moralidade existente na sociedade?

No Documento "Exigências Éticas da Ordem Democrática" da $\mathrm{CNBB}$, há uma afirmação que pode colaborar na tentativa de responder a esta questão:

A existência de milhões de empobrecidos é a negação radical da ordem democrática. A situação em que vivem os pobres é critério para medir a bondade, a justiça, a moralidade, enfim, a efetivação da ordem democrática. Os pobres são juízes da vida democrática de uma nação. ${ }^{11}$

Se concordarmos que democracia signifique algo moral e ético, na medida em que esses pobres sejam os juízes da verdadeira democracia, serão também os juízes da ordem ética. A existência de pobres negaria a ética. Os excluídos seriam os juízes da existência ou suas presenças seria a negação de relações sociais éticas na vida sociopolítica e econômica de uma sociedade.

${ }^{11}$ Conferência Nacional dos Bispos do Brasil, CNBB, n.72. 


\section{Acerca da ética e da perspectiva interdisciplinar}

\section{Tania Mara Galli Fonseca} UFRGS

Inicio minha participação nesta Mesa Redonda colocando duas observações: a primeira, referida à grata satisfação pelo convite que me foi formulado e, a segunda, que tal satisfação não me permitiu, à época, avaliar de modo menos apressado, o teor da comunicação desta Mesa. É preciso que lhes revele, que tal avaliação, estruturada durante a elaboração das ideias que passarei a colocar, posicionou-me, com dificuldades diante do tema, visto que falar de ética, desde uma posição leiga torna-se, hoje, fácil e usual, estimulante até para tomar contundentes nossos argumentos no campo das forças de poder que enfrentamos em nosso cotidiano. Ética tem sido evocada, de modo geral, como uma espécie de apelo que tentamos fazer para demonstrar quão virtuosa ou boa se mostra alguma prática social, algum posicionamento teórico, decisões políticas etc. Passou a fazer parte de nosso imaginário, como algo que sabemos o que é, quando se faz presente, que se acende juntamente com nossa indignação, incorporada ao nosso modo de ver e agir, eu diria, de forma tácita. Tal perspectiva, seguramente impõe dificuldades para colocá-la em palavras, ao nível da razão e o do pensamento. Falar, portanto, de ética, implica a meu ver, um esforço de tornar explícitos aqueles pressupostos que orientam a nossa ação concreta sobre o mundo, e que, enquanto reguladores, também criam a ilusão de nossa autonomia e de nossa liberdade. Falar de ética implica na busca daquilo que, sob a aparência de pessoal e individual, se inscreve como valores sociais estruturados historicamente que, com sua capacidade estruturante modelam os espíritos segundo seus conteúdos.

A tarefa, para os filósofos, certamente seria interpretada e abordada desde outras perspectivas, dentre as quais a da própria história da liberdade, das essências e aparências, do acidental e do essencial, do universal e do singular, provavelmente fundando seus argumentos na própria disciplina originária, a filosofia, em seus desdobramentos da Ética e da Estética.

Como psicóloga, inserida na tradição da Psicologia Social e, mais especificamente, na área do Trabalho, venho a este Encontro, concebendo o campo ético como uma espécie de continente modelador da subjetividade que, na modernidade, assume características de uma individualização orientada pelo narcisismo e pelo egoísmo.

A proposta desta Mesa Redonda, que não sendo redonda, em sua materialidade sensível, deve implicar em um significado coletivo a essa reflexão e daí, a pertinência do adjetivo, uma vez que ele sinaliza para a presença do Outro, para o próprio sentido da alteridade. A metodologia de mesa redonda, se constitui em si como proposta pedagógica, à medida em que estabelece normas e expectativas de funcionamento que superem as dicotomias do individual e do coletivo, do público e do privado, das meras convenções morais frente aos desafios da construção coletiva do mundo. Mundo este, talvez pequeno e efêmero, como o desta Mesa, marcado pela temporalidade, mas quiçá, capaz de objetivar inter-relações como suporte a alguma utopia, fundada tanto na solidariedade como na hibridez das formas e conteúdos. Talvez, tal como máquina, tal encontro e tal mesa possam se transformar em dispositivo social que, venha a se tomar capaz de aquecer as paixões, as vontades e as forças na direção de uma sociedade justa, capaz de conviver para além de seus interesses privativistas e individualistas.

Reconhecer a oportunidade desta Mesa Redonda, e deste Encontro como um todo, como prática social, desde já pedagogicamente orientada por critérios éticos, não se trata, pois, de mera especulação discursiva. Sabemos que se trata de um desafio.

Nós, que vivemos imersas preferencialmente no mundo do trabalho acadêmico, conhecemos, de sobra, as diversas formas pelas quais os valores éticos perpassam nossas relações, sejam internas, sejam com a sociedade em geral. A ciência, não sendo neutra, o conhecimento, não estando acima do bem e do mal, produz-se como forma de poder, podendo ser utilizado como um instrumento de dominação. Comparece ao espetáculo, como um dos asseguradores da capacidade humana de governar o mundo, dominá-lo e controlá-lo. O sujeito do conhecimento cria e manipula os objetos, tomando-se o próprio centro do processo, seu fim último, assegurando desta feita aquilo que a moral moderna celebra com força de glória: a autonomia do indivíduo, colocada aqui, como a mais decisiva característica do projeto da modernidade. A experiência do COGITO impõe-se como experiência absoluta, dispensando qualquer suporte que seja exterior ao homem. $\mathrm{O}$ individualismo, constitui-se, desta forma, como uma espécie de a priori, como pressuposto maior do projeto da modernidade, assegurando que seja 
concedida, ao homem, a ideia e a crença de dono do mundo. Pelo conhecimento, o homem passa a ser senhor do objeto e, por suas descobertas passa a controlá-lo e a dominá-lo. Associando-se a tal acepção do conhecimento, outra comparece para articular-se na consolidação do individualismo. Trata-se do deslocamento do campo da liberdade e de sua restrição à ideia de livre-arbítrio. Deslocada para o interior de cada humano, saindo portanto, tal como para os antigos, das esferas da política e da cidadania, a liberdade, como livre-arbítrio apresenta-se despolitizada, como moral interna, como divisão interior entre mim e mim mesma, entre meu querer bem e querer mal, delimitada pelas possibilidades colocadas pela própria culpabilidade. Não se trata mais, como para os antigos, de vencer o jugo dos tiranos e manter a plenitude da condição de cidadão, nem de dominar a tirania da carne e sim, de afirmar que o homem, pelo livre arbítrio, promove-se à condição de senhor — senhor de sua escolha.

$\mathrm{O}$ conhecimento e a liberdade, em tais concepções, emprestam à autonomia como que sua transparência. A liberdade interpretada como autonomia leva qualquer um de nós a repetir desprevenidamente que $a$ minha liberdade começa onde termina a tua.

Oxigenada pela ideia de indivíduo autônomo e livre, erigindo subjetividades consonantes com tais valores, a modernidade toma problemática a ideia de valores éticos universais. Funda, igualmente, a dissociação entre ética e política, instituindo um contrato social, que se mostra como o drama das sociedades complexas atuais.

Se, cada indivíduo vem resguardado em sua própria autonomia, em que bases se pode estabelecer a vida social? Como conciliar o individualismo com as exigências da existência comunitária?

Ora, a produção das ciências não se dá no vácuo social. Ela se demarca, ao contrário, nos limites da geografia e da história. Nada mais correto, portanto, do que reconhecermos que, as ciências se encontram impregnadas do histórico-social e político, tendo mesmo sido gestadas no seu interior. Fruto do pensamento humano, o conhecimento científico não possui a unívoca direção de construir ou criar o mundo social. Ele se mostra, antes, como efeito desse mesmo mundo, colocando-se, paradoxalmente, enquanto procura e aprisionamento, buscando os desconhecidos, para que os possa domesticar, não sem antes ter-lhes auscultado e extraído, com bons métodos, as confissões e os soluços mais íntimos. Vontade de saber associada à vontade de poder. Construidor de objetos, o homem lhes dá igualmente os sentidos. Tais sentidos circulam, por sua vez, em torno de sua megalomania narcísica, devendo sustentá-lo em sua ilusão de sujeito livre, celebrá-lo como normal diante daquilo que ele mesmo construiu como patológico, devendo, afinal, instituí-lo como centro, para apagar-lhe da consciência a miserabilidade de sua própria condição de ser do mundo e do tempo.

A psicologia não se isenta, portanto, de tais apreciações e de tal funcionamento. Nossa intimidade com seu corpo teórico, permite revelar o quanto tem se constituído em uma produção a serviço da normatização do social.

Erigida a partir da vontade de constituir-se como ciência, revelou, desde seus primórdios, que estava disposta por sacrificar ao reducionismo seu próprio objeto, para que pudesse, no cenário das ciências de então, ser elevada ao estatuto científico. Demonstrou, desde aí, sua capacidade em dissociar meios e fins, adotando critérios que se fundamentam na expressão: os fins justificam os meios. Instalou-se, portanto, já dentro dos limites da modernidade, construindo concepções capazes de dizer que espécies o universo contém como as que ele não contém. Suas teorizações, que vieram a se tornar hegemônicas, têm sido, em geral, fundadas nos pressupostos do cultivo/cultura do individualismo. Apregoando a autonomia, a liberdade, a propriedade, como valores do sujeito moderno, a psicologia, como ciência e profissão tem se revelado como prática discursiva sintonizada com as ideologias de dominação, com a ânsia de padronização e homogeneização, como fonte legítima para instaurar o desvio e o desviante. Sua tradição reprodutora, aponta-a como depositária de ecos da conservação, como guardiã da moral vigente, a qual auxilia a inculcar nos sujeitos sociais, desde sua expansão e aplicação às práticas da socialização e da educação.

Nossa ciência e nossa profissão tem sido capazes de se reforçar mutuamente, colocando-se uma para outra, tal como em círculo vicioso, que busca em si mesmo a autoconfirmação. As perplexidades colocadas por nossa prática profissional, nem sempre têm sido suficientes para que permitam interrogações que, nos conduzam a uma ruptura com o consenso social, firmado em parâmetros orientados para que apenas construamos muros em tomo de nossas próprias casas, sem atentarmos para a própria cidade nas quais elas se inserem. A cidadania se transmuta em desfigurado 
apelo as nossas responsabilidades. Responsabilizamos a todos. Conseguimos, já, nos amortecer na posição de vítimas. Vítimas da violência e inépcia dos outros, restando-nos meramente a indignação quando vemos nossos interesses e patrimônios aviltados e perdidos. Conduta moral, de acordo com os códigos, convenções e leis; isto nós reclamamos para que a sociedade se faça possível. Não temos conseguido, contudo, para além de vislumbrar, nos orientar e sustentar pela visão de um outro plano, no qual se gestam as possibilidades de tais violências. Lutamos contra efeitos, nos armamos e nos protegemos, nos colocamos como legais e convencionais mas, em nossas práticas, e isso nós conhecemos bem, temos um convívio direto e concreto com toda a nossa maestria em transformar o injusto em legal, o sofrimento em culpabilidade individualizada, o verdadeiro infrator em vítima do imerecimento e da revolta alheia. Nossas práticas e o nosso saber se encontram maculados pela tendência em desconcretizar o humano, concebendo-o como entidade exclusivamente interiorizada, regulada por pulsões, que, tal como força da natureza, delimitam como naturais a bondade e a maldade humanas. Falamos sobre a construção do homem, mas nossa tendência, como sabemos, é julgá-lo como nascendo relativamente pronto, sendo que, em nossos silêncios, adotamos a visão discriminadora de que o bom e o mau já nascem feitos. Estranhamente, elegemos para o polo negativo de nossas avaliações, aqueles seres humanos que se mostram mais diferentes de nós: os negros, os pobres etc. Nossas interpretações e diagnósticos, no mais das vezes, precisariam de uma ação desveladora, como se uma mão forte lhes tirasse a máscara de Ciência, deixando a nu e ao cru, aquilo que vestido de legitimidade, mostra-se cozido na cultura ideologizada e individualista.

Sim, desde nossas posições como cientistas e como profissionais, estamos imersos na crise da modernidade. Crise que se revela por algumas destas caracterizações acima apontadas. Crise que foi capaz, por outro lado, de reconhecer a agonia de tais concepções e, revelá-las como presunções oriundas da necessidade de consolidar, frente a experiência da morte e da finitude, a noção de um eu-todo-poderoso e abstrato, que pudesse manter cativas a paixão, a ação, a emoção e a invenção.

O tema interdisciplinaridade parece materializar aspectos da mencionada crise. Embalando os atuais discursos das Ciências Humanas, colocando-se como ponta de lança para a criação de novos paradigmas, a interdisciplinaridade aparece, no meu entender, mais como grito de sobrevivência do que convicção epistemológica. Tomada desde seus desdobramentos práticos, constatamos que as ciências tratam agora de reunir o que antes fragmentaram, pela adoção de referenciais multidiscursivos, tomando por base a complexidade do objeto a ser estudado, como se a agregação de múltiplos se constituísse como suficiente para totalizar a visão/compreensão do objeto. Nada nos garante, contudo, que tal empreendimento possa vir a se constituir como pretensa evolução do refinamento das estratégias da captura.

Se a interdisciplinaridade, contudo, possa ser proposta e praticada à luz de uma nova ética, da qual seria representante concreta e exemplar, se apoiar-se não na simplificação do complexo, mas ao contrário, na complexificação do simples, se representar a difusão de interesses que cultivam os valores da solidariedade, se for construída a partir da noção não do eu-todo-poderoso, mas da alteridade, se se constituir em base para a criação de uma voz e vontade poderosa contra as injustiças sociais, se conseguir, transformar o sentido do INTER, para além das fronteiras disciplinares e acadêmicas, auxiliando a instaurar, nesses perigosos caminhos do Brasil, no lugar da esperança, a busca e a procura ativas, se conseguir explicar a fome, a vergonha do faminto e do desempregado, a patologia do exibicionismo, desde outras acepções que não aquelas vinculadas à meritocracia individualizante, então, sim, podemos pensar em dar as mãos.

Dormiremos mais tarde, porque nossos corações sentir-se-ão, então, acompanhados, não tão temerosos da noite, do tempo e da morte, não mais deslumbrados pelas luzes e pelas claridades, não mais cativos das ilusões da razão iluminada e, finalmente, não mais alocados como prováveis clandestinos no mundo. 


\section{Ética e relações sociais um enfoque filosófico}

Maria Teresinha Abs da Cruz de Agosto PUCRS

Recuso-me a permanecer em um país onde a liberdade política, a tolerância e a igualdade não são garantidas pela lei. Por liberdade política entendo a liberdade de expressar publicamente ou por escrito a minha opinião política, e, por tolerância, o respeito à toda convicção individual.

Albert Einstein (1933).

Cremos que com este pensamento de Albert Einstein traduzimos muito de nossos anseios éticos. Esta frase, retirada de um Manifesto de 1933, conserva ainda hoje a atualidade necessária para a formação de um mundo melhor. E como seria este mundo? Certamente ético. Não há outra alternativa no limiar do século XXI. Um mundo em que as relações primem pela liberdade, tolerância e igualdade. Portanto como o desejado por Einstein logo acima. que não.

E é o que se verifica? Com toda a tranquilidade podemos responder

É só nos debruçarmos sobre a realidade cotidiana para constatarmos a quase inoperância dos ideais éticos no confronto diário da massificação. Busca-se uma ética comunicativa para que o homem possa humanizar-se mais, e deste caminho, fundamental para a sobrevivência, faz parte todas as artes e ciências conhecidas e as que ainda vão surgir. A ética penetra os meandros de toda e qualquer realidade humana, torna-se instrumental e decisiva na elaboração de respostas e perguntas vitais.

E dentre as perguntas mais perturbadoras poderemos elaborar três que nos dariam as pistas para o seguimento deste trabalho:

1. Deve alguém, sendo livre, renunciar à própria liberdade?

2. Deve alguém saudável, renunciar à saúde?

3. É lícito renunciar à vida?
Ora, dificilmente alguém sairia respondendo, com presteza e sem dúvidas, perguntas como estas. A trama das relações sociais em que elas se inserem determina a particular e especial área de aprofundamento na investigação e formulação de respostas adequadas.

Insere-se num mundo de linguagens e tangências que impossibilitam respostas finais, mas, e aí está o seu grande valor, a ética entra como norteadora e condutora nestas relações tão vivas e mutantes porque sociais. E daí, a sua complexidade que não nos deve assustar, e sim, desafiar, colocar-nos na emergência de formulações sobre o novo que se instala em nossas vidas, desentalando-nos.

Somos seres falantes, pensantes, e nosso agir racional envereda para situações concretas que exigem definições constantes. Neste sentido a ética tem muito a oferecer, não em termos de relativismo, mas sob a ótica de juízos universalmente válidos talvez os mesmos que possam responder às perguntas formuladas acima e que nos colocam no uno de processo incessante de busca de justiça, de verdade e de bem. Como responder às exigências diárias do se instável que somos nós e nossas inter-relações?

Para respondê-las é necessário entrar-se no dia-a-dia do trabalho e do amor; na luta pelas realizações através do exercício da cidadania, e sobretudo, no mundo de nossas contradições. E onde estas se verificam?

$\mathrm{Na}$ família, local das mensagens as mais significativas, tentando-se vencer a ambiguidade amor - ódio. Na escola, onde a expectativa de se graduar sujeitos se insere na dicotomia: seres autônomos ou dependentes, logo após aquentando-os e remetendo-os ao mercado de trabalho onde não incomodarão com muitas perguntas. Nas igrejas, esperando-se um messias econômico que encha nossos bolsos, mas não se suje com os papeleiros: um messias asséptico.

Enfim, na sociedade como um todo, as relações se alternam e se reproduzem ora como autoritárias, ora como liberais, possíveis ou impossíveis, merecedoras de punição ou aprovação. E tudo se realiza na cultura ambivalente, pois a mesma cultura da escola faz a guerra, que é contra a pena de morte institucionaliza o aborto. A discrepância causa os conflitos e estes desestabilizam as certezas, gerando uma sociedade sem parâmetros, adormecida. 
Onde está a moral sobre estas práticas?

Como emitir juízo sobre elas?

Domesticar seres humanos parece ser a proposta subjacente à moralização. Em especial neste momento brasileiro há a tendência geral de se acreditar que, em havendo moralização na política, nos costumes, na escola, etc., tudo estará à salvo.

Uma nova religião. Será tão simples o que significa moralização? Algo semelhante a um adestramento, como um desapego da animalidade?

O que é moralização, afinal? que é?

E a ética, palavra usada como medicamento, profilaxia, correção, o

Leva a uma homogeneização, cabendo tudo no mesmo saco? Os valores, as atitudes, os princípios?

Ora, convenhamos, repassar estas noções, será isto que as pessoas, agentes das relações sociais querem e merecem?

Ou o grande patrimônio da humanidade é se conformar com a moral de rebanho sendo dóceis e reprodutores de padrões de comportamento?

Se ética fosse isso, seria o cúmulo do tédio. A uma série de perguntas, se conformaria uma série de respostas, num amálgama justaposto. Seria um ciclo fechado como um catecismo dogmático. E aí, nada haveria de novo no front...

Analisemos o que seja moral. Evidente que dado o nosso tempo, teremos de nos conformar a dados gerais.

Pode-se afirmar que moral é um conjunto de normas que orientam, disciplinam, normatizam os costumes e as atitudes pessoais ou em grupo, ou como poderíamos dizer, a moral trata do lícito e do ilícito comportamental.

Mas esta moral ou moralidades está radicada no tempo. Ela não é supra ou a-histórica. Está inserida no caráter histórico-cultural dos povos. Faz parte de toda e qualquer manifestação humana (ou desumana) em qualquer ambiente ou era. Portanto, existem tantas moralidades quantas forem as culturas. Neste sentido pode-se até concordar com o dito popular que afirma variar a moral de acordo com a latitude e longitude. Mas isto não pode nos confundir, deixando-nos numa incerteza sobre o certo hoje, aqui ou em qualquer lugar. Ou numa confusão de regras que nos parecem absurdas ao lado de outras imprescindíveis.

Uma visão ampla do leque de possibilidades pode nos deixar à deriva quanto ao subjetivismo ou objetivismo dos nossos juízos. E a nossa ação fica desequilibrada, sem um critério mais definitivo, tornando-nos tendenciosos.

Isto se resolve pelo fato de não existir um único ser humano que consiga viver sempre passivamente à margem de seu contexto sociopolítico-cultural.

Há um momento em que, infalivelmente, ou ele o desafia, ou aceita ou renega. Há uma motivação em torno de expectativas que o faz agir, mesmo que depois volte a marginalizar-se numa submissão crescente às regras.

Haverá um tempo de responder sobre a validade ou não do casamento monogâmico; ou do poligâmico; ou sobre o direito de vida e morte de um paciente terminal; ou sobre a nossa visão da escravatura moderna. Todas estas são perguntas que tentam responder de forma racional o valor da vida Todas as morais giram em torno de valores que lhes condicionam e conformam. E toda a moral está imbricada na vida. A moral que não considerar como fonte de referência a vida em seus aspectos de liberdade, justiça e bem, repetimos, não merece ser considerada. Não está a serviço do homem, está, isto sim, fazendo o sábado para o homem e não o inverso. Estes cuidados devem nortear os estudiosos de ética, na atenção especial à não inversão dos valores

Este é um perigo sempre próximo e muitas sociedades acabam valorizando mais a cultura da morte do que a da vida.

Podemos saber proceder diante deste quadro, pois é nestas noções primárias que exigem discernimento, que se estabelecem os primeiros passos para a diferença entre moral e ética.

A moral se situa num plano variado social, legal, cultural em que nos situamos. Ao tomarmos conhecimento de outros códigos antagônicos, a nossa atitude é de surpresa, às vezes seguida de recusa em aceitá-los. Custanos sair de um modo de vida estabelecido e aceitar outros. Mas, se fizermos 
estudos criteriosos sobre todos os possíveis códigos de ética existentes, verificaremos a riqueza existente tanto nas semelhanças como nas diferenças pelo poder criativo do homem.

Estes são fatos que deveriam colaborar para a maior tolerância entre os homens no entendimento e aceitação das diferenças, fatores que Einstein preconizava como faltosas na Alemanha de 1933 e, que muitos séculos antes crucificaram Cristo.

Através de caminhos díspares como a ciência e a religião, pode-se verificar a existência de critérios essenciais a toda e qualquer cultura, estruturas que permanecerão as mesma, seja na relação homem - meio, seja na relação homem - ele mesmo.

E como analisar estes componentes, extraindo o que há em comum em todas as sociedades? Em resumo, o que é essencial, próprio do ser humano?

Aí é que entra a ética, como uma reflexão sobre as várias morais que são os referenciais para as atitudes, ideias e valores inerentes a todos os povos enquanto demonstradores dos padrões estáveis e de mudança. A ética colhe-os em dados e, nesta coleta, faz a decantação para que se possa separar, juntar, arquivar a várias correntes, estabelecendo os pontos em comum.

Estas mudanças são os desafios para a ética. Por isto, dizíamos, ética não rima com tédio. Nunca. Como apassivá-la se em sua relação com o mundo vital participa efetivamente dos questionamentos do Direito, da Psicologia, da Sociologia e outras áreas?

A ética insere-se numa configuração platônica ao buscar a perfeição através de modelos ideais, portanto, é o mundo real que importa. Colher dados a partir da realidade, sem no entanto tirar os olhos de um mundo solidário, já é uma atitude ética de extremo desafio e esperança.

Como o fenômeno moral deixa fragmentos subjacente à todas as culturas, é necessário que o compreendamos racionalmente num universo de diálogo, argumentativo, pois não há justificativa sem compreensão, nem compreensão sem justificativa.

Os conceitos éticos se circunscrevem a um universo em devir, em processo de relaboração permanente dos momentos indicativo - eu sou, ao lado de um momento imperativo - eu devo ser, tudo vivido dentro das circunstâncias limitantes. Acreditamos que agora já seja possível afirmar que a moral é o conteúdo paradigmático, ou seja, o modelo para a reflexão ética, o material que é capaz de apresentar as teorias que definem, confrontam e delimitam os vários comportamentos humanos.

Pode-se constatar que a luz que ilumina a ética não são os fatos brutos, e sim os valores deles imanentes. E é um valor subjacente ao desejo humano, duelando com o interesse-interesseiro do bem comum. Combatendo o próprio egoísmo, o homem vê na busca do bem-comum, o resguardo de sua integridade. O bem-comum torna-se o poder dividido, enquanto preservado pelas leis.

\section{E o que são leis?}

É o que possibilitou a passagem do mundo animal — regido apenas pelos instintos, imutáveis e repetitivos, que visam apenas a autopreservação e a perpetuação das espécies -, para o mundo humano, que pensa, vê e age (ou deveria assim sê-lo) adiante dos instintos básicos.

Para que se faça parte do contingente humano, exige-se o uso da responsabilidade e da liberdade, sem o que não saímos do mundo da má-fé. Só se pode tratar o homem na sua totalidade e finalidade, ou seja, o ser integral buscando o máximo da realização humana que é a autoperfeição.

\section{No começo perguntávamos: Pode-se renunciar à própria liberdade?}

Ora, qualquer ser responsável e livre terá como valor inalienável a vida em sua integridade física. A ética, ao refletir sobre a questão da sobrevivência, proclama a vida como o bem maior e isto subjaz a todo o comportamento.

E é necessário um elo que sirva de intermediário nas relações humanas que é a tolerância, que Einstein definia como o respeito a toda convicção individual embora se possa constituir em um grave problema quando a pergunta se reverte a nós: Devemos tolerar nossa própria intolerância? De que forma, a fim de que se enriqueçam as relações sociais? Estabelecendo pontos de contato, tangenciando pontos em comum nos vários conflitos, para poder dissipá-los num empenho máximo pela paz. Isto não contraria o empenho do homem realizar a sociedade perfeita e todos temos como embrião, ideias isoladas. A soma de todos formaria o todo completo, mas para tal é preciso pensar. Pensar sobre a necessidade do 
outro, de estar com os outros através de relação pacífica, não pacíficamorta, mas exuberante.

Pensamento e ação, eis a tônica das relações sociais na sua origem, reprodução e difusão. E qualquer prática ou teoria que não inclua o homem concreto nas várias áreas científicas, sociais, políticas, o exclui. Não há meio termo. Por isto há uma forte relação dialética de conflito entre a ética e as relações sociais. Enquanto a ética propõe a efetividade dos princípios humanos os mais essenciais, por outro lado as sociedades se estruturam, desestruturam e reestruturam em novas concepções, atendendo aos novos anseios da humanidade.

Mas em todo este processo algo salta aos olhos como básico em todos os tempos e culturas: nunca será ético tolerar a miséria, dar vazão livre à injustiça, violentar-se na corrupção.

Mudam os tempos, mudam as visões de mundo. Que direção tomamos? Humanização ou desumanização?

Se optamos pela desumanização, a ética torna-se estética, porque não há nada mais belo do que a descoberta da própria humanidade, que dá sentido e valor à vida.

Enquanto houver peregrinação do homem para o seu aperfeiçoamento, haverá esperança, talvez a palavra de mais sentido ético para o homem, tudo inserido num processo democrático. Mas qual democracia?

Aquela que é sempre e de novo inventada, reinventada, num exercício crítico de transformação da realidade pela conscientização.

Como a liberdade, ela não pré-existe em qualquer barro a ser moldado, pois é conquista.

Como em todos os sistemas, admite-se o conflito gerador das contradições. Sem conflito há a estagnação dos totalitarismos, nos quais o poder é exercido sem controle. Nas democracias de todas as formas (familiar, escolar, governamental, etc.) deve o controle ser o olhar que aponta para a autonomia e que admite a diversidade. O grande perigo é idealizarmos todo um ritual democrático fora de nós e não dentro de nós. Praticarmos uma hipocrisia cuja embalagem é caiada por dentro.
Também devemos nos perguntar: Qual o sentido da democracia?

A resposta pelo seu sentido talvez nos seja dada pela democracia como moral, que pode nos levar a um estado de justiça. Isto embasado no fato de que há no coração do homem o desejo de uma sociedade do homem, pelo homem e para o homem. E talvez nesta grandeza esteja justamente a sua fraqueza. Colocando-se como meio e fim, como um círculo concêntrico, o homem se esquece de sua visão transcendente, para além de seus limites.

Qual o sentido emocional da democracia?

Talvez a resposta esteja no prazer da democracia, de vivê-la no intercâmbio de ideias, na responsabilidade da emissão de juízos, na esperança da mudança para um mundo solidário.

E a mensagem que deixo a todos é que possamos viver neste prazer num amanhã bem próximo, num mundo em que as relações sociopolíticoculturais estejam impregnadas de sentido ético na comunicação e participação.

\section{Referência bibliográfica}

EINSTEIN, Albert. Como vejo o mundo. Rio de Janeiro: Nova Fronteira. $6^{\mathrm{a}}$. Ed., 1981. p.104. 


\section{A terra e o equilíbrio humano}

Ivo Poletto

CPT-CNBB

\section{A questão da terra}

Para repensar o Brasil, criticamente e movido pela busca de uma nova utopia, Cristovam Buarque enumera dez erros cometidos pelos responsáveis por decisões políticas tomadas desde 1930. O primeiro deles - e como uma base que se mantém até hoje — foi e é este:

a implantação de uma política de substituição de importações de bens industriais, sem modificação na estrutura da propriedade da terra e no produto da agricultura que continuou baseada em latifúndios voltados às exportações. ${ }^{1}$

Acumularam-se a este, outros erros, resultando na situação atual, que o autor define como de "apartação social": uma sociedade com um pequeno número participando das benesses do mercado, isolando-se e "protegendo-se" da maioria que vive em situações de exclusão social. Ou, ao contrário, uma sociedade formada por uma maioria de excluídos das condições mínimas de vida, ao lado de uma minoria de privilegiados. Isto configura uma sociedade que discrimina a maioria numa forma disfarçada de "racismo", baseado não na cor, mas na incapacidade de participar do mercado.

Não creio ser necessário ficar repetindo números para demonstrar que isto continua sendo promovido pelos grandes proprietários de terra do país. Lembremos, apenas para referência: os $67 \%$ estabelecimentos agrícolas, com propriedades de até 20 hectares, ocupam apenas $6 \%$ da área registrada; já os $1 \%$ desses estabelecimentos, com propriedades acima de 1000 hectares, ocupa $44 \%$ de toda terra registrada; somando os estabelecimentos

\footnotetext{
${ }^{1} \mathrm{O}$ cercamento das terras em grandes propriedades, protegidas por Códigos de Direito que consagram a propriedade como um direito absoluto, fonte originária dos demais direitos, significa a consagração da dependência da quase totalidade da população aos desejos e decisões de menos de $0,7 \%$ dos cidadãos: quem controla monopolisticamente a terra, controla a população que depende dela para viver.
}

com mais de 100 hectares, representam 9\% das propriedades, mas controlam $79 \%$ de toda terra registrada. ${ }^{2}$

A introdução da política de modernização agrícola, promovida especialmente pela última ditadura juntamente com uma política agrária que confirmou e aumentou a monopolização capitalista da terra em grandes propriedades, ${ }^{3}$ provocou um terrível êxodo rural, invertendo a percentagem da população urbana e rural em menos de 50 anos: em 1940, 30\% dos brasileiros viviam nas cidades; em 1990, as cidades já abrigavam mais de 74\% dos brasileiros. Este é um deslocamento populacional que a Europa, por exemplo, demorou 400 anos para completar.

A orientação mais recente incentiva a indústria e a agricultura a assumirem as tecnologias de última geração, capacitando-se para concorrer no mercado internacional. Somando-se as duas orientações - a manutenção da grande propriedade e a reconversão produtiva — chega-se ao grau de exclusão social que se verifica a olho nu na sociedade brasileira, hoje simbolizada nos 32 milhões de indigentes que perambulam pelas ruas da cidade e pelas estradas do país em busca de qualquer oportunidade de sobrevivência.

\section{Terra e desequilíbrio vital das pessoas}

Recentemente, num encontro com agricultores e agentes pastorais da Igreja Católica, os participantes disseram que um dos sentidos da Terra para os seres humanos é ser saúde. Insistiam: se a Terra for bem cultivada e tratada com carinho, ela é, e de muitas formas, fonte permanente de saúde. Ela gera formas de vida que purificam o ar que respiramos; ela gera os alimentos que necessitamos; dela nascem remédios para nossas doenças; ela ajuda a descarregarmos nossas tensões; dela tiramos os elementos que nos permitem construir moradias, meios de transporte, instrumentos de trabalho etc., e tudo isso tem a ver com uma vida feliz, que é a saúde dos humanos.

\footnotetext{
${ }^{2} \mathrm{O}$ destino da maior parte das terras a uma pecuária extensiva, irracional, antiecológica, ou a monoculturas de produtos destinados à produção de energia automotriz e bens de exportação, forçando que projetos de colonização ou de reforma agrária restrita sejam implantados nas reduzidas áreas cobertas por florestas, muitas vezes territórios indígenas, distantes dos mercados consumidores e com agriculturas não adequadas às regiões ocupadas. ${ }^{3} \mathrm{O}$ desmatamento e a queima das matas e dos campos, empobrecendo o solo.
} 
Ao tratar a Terra do jeito que fazemos no Brasil e no mundo, porém, estamos apostando em quê? Para ver alguma racionalidade nas formas de relação social e jurídica com a Terra, é preciso imaginar que algumas pessoas ou setores sociais tiram vantagens com a irracionalidade que elas representam. Em outra palavras, imaginar que há doidos tirando vantagens com a generalização de condições de desequilíbrio vital. Ou como diriam os cientistas suecos, existem loucos que lucram com a aposta num "suicídio coletivo", cinicamente denominado "desenvolvimento". 4

Existem alguns componentes particularmente graves nas formas de relação com a Terra no Brasil. Destaquemos alguns:

\section{Como sair dessa e construir alternativas?}

Ninguém, minimamente ajuizado, pode aceitar que a situação da propriedade e do uso da terra no Brasil continue como está. Afinal, ainda que em muitas oportunidades parte dos seres humanos revelem menor respeito e amor pela sua espécie que os próprios animais, não podemos perder a fé na humanidade.

Mas seria ingenuidade imaginar que isso acontecerá mecanicamente, como fluxo do processo de desenvolvimento materialista impulsionado pela modernidade. Pelo contrário, se depender deles, é mais provável que passem a produzir bens naturais para seu consumo, enquanto abarrotam o mercado com produtos cheios de venenos e outros ingredientes prejudiciais à saúde dos consumidores. Além disso, podem muito bem poluir os próprios conceitos, redefinindo, depois de apenas maquiar, suas atividades predadoras como sendo exemplos de "sustentabilidade".

Diante disso, é fundamental ter clareza acerca dos aliados de uma libertação integral da terra, que para os cristãos, segundo a palavra do apóstolo Paulo, "sofre dores de parto... ansiosa pela manifestação da liberdade dos filhos de Deus" (Rom, 8). Quem serão esses "filhos de Deus", esses seres humanos que revelarão o bom "sonho da Terra", na feliz expressão de Thomas Berry?

4 A implantação de formas inadequadas de agricultura, promovidas sem o devido conhecimento das condições agroecológicas de cada região e determinadas pela lógica suicida de máxima produtividade no curto prazo, não se importando com a morte da natureza já para esta geração.
Aqui no Brasil, mesmo com grandes limitações e diversificadas contradições, essa luta pela libertação da terra está sendo liderada pelos movimentos de Sem Terra - incluídos os Povos Indígenas -, e conta com apoios e solidariedade de todos que já perceberam a necessidade deste caminho.

Além de ser uma luta com a marca indiscutível da democratização de relações e de oportunidades de vida, esta luta significa uma abertura de novas possibilidades de terapia, a recuperação do espaço da Terra para os seres humanos. As cercas, além e junto com os males sociais, provocam as concentrações urbanas praticamente inadministráveis, forçam a maioria da população a viver sob a ditadura do ritmo de tempo da indústria e da informática, sem possibilidades sequer de descarregar suas tensões e energias negativas no contato com a Mãe-Terra.

Até o presente, as Ciências Humanas, localizadas nas cidades e determinadas pela cultura industrialista dominante, não têm levado a sério as afirmações da sabedoria dos mais velhos, quando dizem que seu ritmo de vida era bem melhor, quando dizem que, mesmo mais pobres, viviam mais felizes, quando lastimam a morte das festas ligadas aos tempos da natureza... Pensamento conservador? E por que não conservar tudo que é bom e favorável à vida humana?

Não teria chegado o tempo de retomar tudo isso, buscando a verdade presente nessas afirmações, redescobrindo a importância decisiva da libertação da terra para o equilíbrio psicossomático do ser humano?

Se os psicólogos, com a liderança científica da busca de equilíbrio para os seres humanos, afirmarem esta dimensão das lutas pela terra, estarão dando nova força, novo sentido, nova legitimidade, nova abrangência a dois tipos de movimentos sociais: os que lutam pela libertação da terra para nela viverem e produzirem com novas tecnologias, e os que lutam a favor da salvação e da afirmação de novas relações com o meio ambiente da vida, que buscam renovar nossa sensibilidade na relação com a terra, pensando em nossa sobrevivência com integridade. Não seria esta uma possibilidade de arejamento para a própria psicologia?

A título de conclusão, vale destacar que o Brasil não será democrático verdadeiramente sem realizar uma reforma agrária profunda, que inclua toda uma reeducação dos que vão relacionar-se produtivamente 
com a Terra e dos consumidores de produtos agrícolas. Uma reforma social e cultural deste porte pode ser fonte de movimentos sociais poderosos, capazes de determinar políticas públicas que corrijam a orientação. da indústria, passando do químico e do produtivista a qualquer preço, para a elaboração de instrumentos e insumos que potenciem trabalhos produtivos que serão feitos em colaboração e com grande respeito pela Terra.

Isto significa apostar num Projeto para o Brasil que seja definido a partir da população, seus valores éticos, seus sonhos e mitos, suas aspirações, suas necessidades, suas esperanças e paixões, suas potencialidades e possibilidades concretas. Não creio que um projeto assim inovador possa ser implementado por alianças entre oligarcas empedernidos e neoliberais conservadores, servos de um projeto definido a partir dos interesses financeiros dos grandes grupos econômicos internacionais, formulado e implementado por organismos financeiros multilaterais como o FMI e o BIRD. Por outro lado, um projeto assim universal e democrático não pode ser limitado aos interesses corporativos nem dos trabalhadores assalariados dos setores atualmente beneficiados em nossa sociedade, nem aos interesses das oligarquias. Somente um crescimento político do conjunto dos atores políticos da sociedade, acolhido e reforçado por um governo com vocação realmente democrática, será capaz de dar vida a este caminho de renovação das relações sociais.

\section{Referências bibliográficas}

Cristovam Buarque. A Revolução nas Prioridades. INESC/INED, Brasília, 1993, $2^{\mathrm{a}}$ ed., p.16.

IBGE, Censo Agropecuário, 1985.

Cf. José de Souza Martins. A Militarização da Questão Agrária no Brasil, Ed. Vozes, Petrópolis, RJ, 1984, especialmente p.28-61.

Cf. Manfred Max-Neet. Chamar de Desenvolvimento a um Suicídio Coletivo. In El Canelo, 35, julho de 1992, Santiago, Chile.

\section{Trabalho e tempo livre: uma abordagem crítica}

Paulo Valério Ribeiro Maya UFRGS/PUCRS

Introdução: a relação entre trabalho e tempo livre

A luta pela redução da jornada de trabalho tem uma história secular nos movimentos de trabalhadores em todo o mundo. Surgida na primeira metade do século passado, ainda hoje ela é incluída na pauta de reivindicações de quase todos os sindicatos, especialmente os operários. Luta-se por mais tempo livre. Há uma concordância mais ou menos generalizada entre todos os autores que se ocupam do assunto, de que o tempo livre vem aumentando nas sociedades industriais modernas, em particular nas mais desenvolvidas. Efetivamente, se examinarmos a situação da classe trabalhadora hoje, em relação à duração da jornada de trabalho, comparando-a com a do século passado, quando as jornadas se estendiam por quatorze ou mais horas, chegaremos à constatação de que o trabalhador moderno tem mais tempo livre.

Em função disso, tem havido um crescente interesse pela questão do tempo livre, especialmente nas Ciências Sociais. Embora não muito numerosos, alguns estudos tem sido publicados sobre o assunto, enfocandoo desde diversos pontos de vista. Consideramos especialmente produtivos aqueles que abordam o tema em conexão com a questão do trabalho, pois afinal, tempo de trabalho e tempo de não trabalho é exatamente do que se compõe a vida dos indivíduos. É imprescindível, então, para o estudo do tempo livre, articulá-lo com o estudo do trabalho, geralmente considerado como sua antítese.

Nas sociedades capitalistas, onde o pensamento liberal é hegemônico, o trabalho tem sido sistematicamente exaltado (o trabalho enobrece, ricos são os que trabalharam mais, etc.) enquanto que ao tempo livre tem sido atribuído o estigma do desvio social (o ócio é o pai de todos os vícios). De acordo com esta maneira de pensar, todo o esforço e interesse do indivíduo devem se voltar para o trabalho, e o processo de socialização no capitalismo prepara efetivamente o trabalhador para essa realidade. A exaltação do trabalho feita pelo discurso ideológico dominante funciona como 
contrapartida da desvalorização do trabalhador. Na medida em que, para a maioria dos membros da sociedade, trabalho é sinônimo de sofrimento, é preciso dourar a pílula, imprimindo nas mentes dos trabalhadores a ideia de que o homem digno é aquele que trabalha e aqueles que assim não procedem estão destinados ao fracasso.

Assim, entende-se porque o trabalho foi sendo enaltecido, disciplinado, cronometrado, administrado sob a perspectiva a acumulação, culminando na célebre expressão: "tempo é dinheiro"; o não trabalho é visto como dupla perda: de tempo e de dinheiro; daí a hostilidade contra feriados, carnaval, Natal emendando com Ano Novo, Copa do Mundo, Semana Inglesa, etc. Se o que conta é o dinheiro, o tempo de não trabalho só tem sentido como repositor de energia para o trabalhador (Oliveira, 1986, p. 8).

Enquanto o tema do trabalho tem sido já exaustivamente estudado, apenas recentemente surgiram pesquisas sobre o tempo livre visto sob o ângulo das classes sociais. É possível, por exemplo, encontrar estudos sobre o tempo livre onde os sujeitos são tratados como se estivessem socialmente igualados e com as mesmas possibilidades de acesso a recursos e bens de consumo. Porém, o tempo livre do trabalhador assalariado é quantitativa e qualitativamente diferente do tempo livre do proprietário do capital, daquele que usa a força de trabalho para extrair a mais-valia.

Trabalho e tempo livre devem ser entendidos desde uma perspectiva histórica em que ambos são parte de um mesmo processo, regidos fundamentalmente pelas mesmas regras gerais. Essas regras são as do modo de produção capitalista, algo que podemos chamar lógica da produção de mercadorias e valem tanto para o tempo de trabalho como para o de não trabalho.

A produção de mercadorias passa a referir a si, às suas exigências, o conjunto das atividades e relações humanas. A lógica dessa produção torna-se a lógica dominante da prática social, organizando e atribuindo sentido e valor às ações humanas (Valle, 1988, p. 46).

Em sociedades onde tudo, inclusive o ser humano, é tratado como mercadoria, como um objeto a ser colocado em um mercado impessoal e todo-poderoso, o tempo livre não foge à regra, seguindo a tendência alienadora do trabalho. A lógica da produção de mercadorias, atuando sobre o tempo livre do trabalhador, toma-lhe um espaço que poderia ser usado para a reflexão crítica sobre si mesmo e sobre sua realidade, reduzindo e/ou homogeneizando suas necessidades, sufocando seus desejos, criando novas e falsas necessidades, com reflexos profundos em sua personalidade, em suas relações com os outros e com o mundo.

Se o trabalhador se aliena em sua atividade de trabalho, percebendo um mundo onde as relações humanas são reificadas, é lógico pensar que a alienação se estende também ao tempo livre, que também aí não é dono de si mesmo e que as atividades exercidas durante o tempo livre sob a influência da lógica da produção de mercadorias reproduzem, reforçam e legitimam as relações de trabalho capitalistas.

\section{Definições: o que são trabalho e tempo livre}

Existe uma definição de trabalho com a qual opera grande número de teóricos críticos:

O trabalho é a atividade racional do homem com a qual ele adapta os objetos da natureza, de modo a satisfazer suas necessidades (Sávtchenko, 1987, p. 7).

O trabalho significa para o homem sua objetivação no mundo, a exteriorização de sua personalidade, a forma como se diferenciou de outros animais e a maneira como sustenta sua existência. $\mathrm{O}$ trabalho está na origem dos homens, como quando resolveram cooperar pela sobrevivência, o que significa trabalhar, pois o trabalho é uma atividade precipuamente social.

Uma definição mais apropriada da noção de trabalho parece ser a de Sanchez Vasquez (1986), que emprega o termo práxis com o mesmo sentido que aqui damos à palavra trabalho:

Por isso, inclinamo-nos pelo termo "práxis" para designar a atividade humana que produz objetos, sem que por outro lado esta atividade seja concebida com o caráter estritamente utilitário que se infere do "prático" na linguagem comum (Sanchez Vasquez, 1986, p. 5).

Esta definição amplia a anterior, tornando clara a inclusão na categoria trabalho daquelas atividades que, embora não produzam um objeto concreto, implicam um determinado objetivo a ser alcançado ou algo a ser realizado (o trabalho intelectual, por exemplo, que nem sempre produz um objeto). 
Sobre o tempo livre, expressão à qual nos filiamos em nosso estudo, não há uma concordância geral dos autores em relação ao seu significado. Muitos entendem que tempo livre confunde-se com todo o tempo de não trabalho que inclui, por exemplo, as horas dedicadas ao sono, à alimentação e à higiene pessoal. Estes autores preferem usar as palavras lazer ou ócio e encontramos frequentemente na literatura o emprego destas palavras com o mesmo sentido que aqui damos a tempo livre, embora outras vezes tenham um sentido mais restrito. E o caso da palavra ócio, muitas vezes empregada para designar o tempo em que o indivíduo permanece sem realizar quaisquer atividades, principalmente físicas (mesmo esportes ou jogos) fora de seu tempo de trabalho.

Preferimos entretanto a expressão tempo livre por nos parecer mais significativa e sugestiva daquilo que desejamos expressar. Além disso, não carrega de modo geral outras conotações associadas, como é o caso da palavra lazer, geralmente relacionada com diversão e recreação; ou da palavra ócio, que além do significado mencionado acima, possui um sentido negativo, depreciativo, em função da referida valorização do trabalho pelo discurso ideológico hegemônico.

Assim, tempo livre significa aquele tempo de não trabalho em que não há uma atividade imposta desde fora ou autoimposta, quando o indivíduo pode escolher livremente aquilo com que deseja ocupar-se (ou não ocupar-se). Ficam portanto excluídos da noção de tempo livre o período dedicado às tarefas domésticas (na maior parte dos casos obrigatórias, especialmente para as mulheres), bem como o tempo dedicado ao sono, alimentação e demais necessidades físicas. A chave para a compreensão do conceito de tempo livre é a ideia de nãoobrigatoriedade, não imposição de qualquer espécie, pressupondo que o indivíduo tenha ao menos a possibilidade de escolher livremente.

\section{A Psicologia, o trabalho e o tempo livre}

A Psicologia pouco tem se preocupado com as questões do trabalho e do tempo livre. Afora as chamadas Psicologia do Trabalho, Organizacional ou Industrial, etc., cuja intenção jamais foi entender o homem, mas aumentar sua produtividade no trabalho em benefício dos detentores do “capital, o psicólogos em geral omitem a perspectiva de entender o indivíduo também por seu trabalho.

... o saber psicológico se mantém pudicamente afastado das relações de produção, ou seja, do homem concreto, e tem se exilado na família como único instrumento de análise social do homem. (Codo, 1993, p. 51).

Já foi dito que não existe uma Psicologia, mas várias Psicologias, dependendo da visão de mundo e de homem que sustenta as diversas tendências dentro do campo psicológico. Trata-se de um viés ideológico evidente que torna o corpo de conhecimentos que chamamos Psicologia um conjunto de teorias dificilmente relacionadas entre si e muitas vezes conflitantes.

O problema está em que estas áreas (da Psicologia) não são áreas, no sentido de uma delimitação do fenômeno a ser abordado, são concepções diferentes a respeito do mesmo fenômeno e de suas determinações (Codo, 1993, p. 30)

Já é hora pois de os psicólogos dedicarem mais atenção ao trabalho, integrando-o a uma perspectiva mais geral do ser humano, pois o trabalho é uma dimensão fundante da personalidade do homem e uma categoria central para a análise e compreensão do indivíduo e da sociedade que ele constrói e transforma.

\section{Uma visão histórica da relação entre trabalho e tempo livre}

Existem duas grandes vertentes através das quais podemos analisar a evolução histórica do binômio trabalho/tempo livre na cultura ocidental. A primeira delas agrupa várias linhas de pensamento com a característica comum que denominaremos valorização do tempo livre. 


\section{a) A valorização do tempo livre}

Como é sabido, a antiguidade em geral desprezava o trabalho. Na Grécia Clássica, por exemplo, qualquer atividade física ou manual (exceto os esportes e a guerra) era considerada como indigna dos homens livres e própria dos escravos. Para Platão, o homem deveria eximir-se de qualquer contato com o mundo material, pois a vida era essencialmente contemplação. $O$ trabalho, ou genericamente qualquer ligação com a realidade empírica, era visto como um obstáculo à contemplação das ideias perfeitas, imutáveis e eternas. Há em Platão uma nítida separação entre teoria, como atividade propriamente humana, e prática, como atividade que avilta o intelecto e deforma o corpo. Considerava, por exemplo

... humilhante para a geometria sua aplicação a problemas práticos e, dentro de uma mesma ciência, estabelece uma distinção entre a ciência "sábia" e nobremente teórica e a vulgar e baixa, de caráter experimental (Sanchez Vasquez, 1986, p. 23).

Aristóteles segue seu mestre na desvalorização do mundo prático e material. Para ele, uma sociedade não podia tolerar que seus cidadãos se dedicassem a atividades como as do operário ou do comerciante, pois elas afastavam o homem da virtude. $\mathrm{O}$ trabalho, para Aristóteles, tornava o homem escravo do mundo material e era, por conseguinte, indigno dos homens livres. O homem só se realizava verdadeiramente na vida teórica.

Essa concepção deve ser entendida no contexto da ideologia dominante na época e como correspondente às condições sociais existentes nas cidades gregas. Em uma sociedade baseada na divisão em classes sociais, fundada na produção escravista, essa separação era perfeitamente cabível: havia suficiente abundância de mão de obra escrava de modo a satisfazer as necessidades materiais existentes então, o que tomava possível ao cidadão grego dedicar-se à contemplação, à filosofia, à teoria.

Embora um tanto modificada, a concepção grega da valorização do tempo livre e desprezo pelo trabalho conservou-se entre os antigos romanos. Diferentemente dos gregos, para quem o tempo livre tinha uma finalidade em si mesmo, predominou entre os romanos uma concepção de tempo livre como descanso e diversão: havia no Império Romano uma classe que, embora liberada do trabalho pela existência dos escravos, não se dedicava à contemplação. Ainda assim, persiste a desvalorização do trabalho:
Essa classe ociosa não tem preocupação contemplativa, na maioria dos casos, mas é concorde com os gregos no que respeita ao desvalor do trabalho e no significado altamente positivo do tempo livre, ainda que não consiga lhe dar a forma de ócio que vigorava entre os helenos (Bacal, 1988, p. 37)

Nos primeiros tempos do cristianismo e durante quase todo o período da Idade Média, permanece vigente a concepção de desvalorização do trabalho e valorização do tempo livre. De acordo com a visão cristã dominante à época, o homem em pecado havia sido expulso do paraíso (paraíso definido não só pela presença de Deus, mas também pela ausência da necessidade do trabalho) e precisava agora ganhar a vida "com o suor de seu rosto". Assim, o trabalho é visto como um castigo imposto, um testemunho da imperfeição do homem e até mesmo um meio de purificação. Havia a valorização de certas atividades manuais, especialmente as artísticas, mas sobre todas elas preponderava a meditação, a contemplação e a exaltação do Divino.

Mesmo quando tolerava as mundanidades, tanto na Igreja como entre os leigos, (o pensamento cristão na Idade Média) considerava a vida neste mundo menos importante que a vida futura, entendendo que os trabalhos e as dificuldades deviam ser suportados, enquanto se aguardava a felicidade eterna (Bacal, 1988, p. 39).

A explicação religiosa da realidade dava sustentação a um sistema social onde a desigualdade existente entre os homens era explicada como um inevitável desígnio divino e onde a submissão aos preceitos bíblicos, segundo a interpretação da Igreja Católica, devia ser absoluta e inquestionável. Essa situação só viria a se modificar com a desarticulação do processo feudal e o início do desenvolvimento do capitalismo mercantil.

A partir desse momento, as concepções sobre o binômio trabalho/tempo livre passam por uma inversão histórica, acompanhando as transformações econômicas e sociais então em curso no mundo ocidental.

Porém, ainda dentro do conjunto de ideias que agrupamos sob o nome de valorização do tempo livre, é necessário destacar uma importante contribuição moderna que, destoando da tendência geral de exaltação do trabalho, oferece um interessante ponto de vista alternativo. 
Trata-se do socialista francês Paul Lafargue, cuja análise da questão do tempo livre do trabalhador merece uma menção destacada. Lafargue foi um crítico ácido e virulento da moral do trabalho vigente em sua época. Frequentemente citava os filósofos gregos para demonstrar o quanto a ideia de trabalho era repugnante. Criticava com veemência o que chamava de paixão moribunda pelo trabalho existente entre o proletariado europeu na metade final do século passado, que levantava como bandeira de luta $o$ direito ao trabalho:

Na sociedade capitalista, o trabalho é a causa de toda degeneração intelectual, de toda deformação orgânica (Lafargue, 1983, p.25).

Sempre denunciando a condição miserável a que o trabalho na sociedade capitalista havia relegado o operário, Lafargue entretanto não se refere ao trabalho em uma futura sociedade socialista como revestido de um caráter diferente:

É preciso que ele (o operário) se obrigue a não trabalhar mais que três horas por dia, não fazendo mais nada, só festejando pelo resto do dia e da noite (Lafargue, 1983, p. 37).

Ao contrário de muitos outros pensadores marxistas, inclusive o próprio Marx, atribuía ao trabalho em si, e não apenas às relações de produção capitalistas, as razões da miséria humana que descreve com paixão. Sua visão do futuro, limitada pelas experiências de seu tempo, preconizava para o trabalhador liberto longos dias e noites de festas, espetáculos, representações teatrais e jogos, boa alimentação e bons vinhos. É preciso notar que essas atividades correspondiam às práticas que eram organizadas pelas associações sindicais dos próprios trabalhadores, já que, à época, o tempo livre dos operários era dirigido exclusivamente por eles mesmos. Questões como o monopólio capitalista da indústria cultural e a manipulação do tempo livre do trabalhador por uma cultura de massas fabricada não faziam parte de seu horizonte histórico.

A posição de Lafargue merece ser destacada porque, como já dissemos, difere totalmente de seus contemporâneos.

Em sua opinião, não há trabalho alienado e trabalho libertador, como queria Marx; existe só o trabalho embrutecedor e o ócio prazenteiro (Perez Ledesma, 1980, p. 156).
Esta original contribuição de Lafargue, entretanto, não encontrou muito eco tanto entre os pensadores socialistas como nas próprias reivindicações dos movimentos operários contemporâneos. Mesmo as lutas travadas pela redução da jornada de trabalho não tem a visão do tempo livre como um fim em si mesmo, mas como uma simples forma de recomposição da força de trabalho.

No fundo, a incapacidade das organizações sindicais e dos partidos da esquerda clássica para colocar radicalmente o problema e para defender uma autêntica alternativa, baseada no prazer e não no trabalho, não passa do resultado último da incapacidade do marxismo - e de todo pensamento socialista, com exceção de um ou outro teórico "marginal" como Lafargue - para elaborar uma doutrina coerente, desligada dos tópicos da intelectualidade burguesa e das apologias do "trabalho não alienado", fruto milagroso da revolução social sempre próxima e nunca realizada (Perez Ledesma, 1980, p. 159).

\section{b) A valorização do trabalho}

Se em toda a Antiguidade Clássica e boa parte da Idade Média o tempo livre foi extremamente valorizado em contraposição a uma visão negativa do trabalho, a desagregação do regime feudal começa a mudar essa realidade. A partir das transformações materiais concretas ocorridas com a ascensão da burguesia mercantil a partir do século XV, com o acúmulo de capitais financeiros devido ao comércio internacional, a expropriação de terras e bens de pequenos proprietários e da Igreja, a ampliação do mundo econômico decorrente das descobertas, ocorre o surgimento dos grandes Estados modernos, sendo fortalecidas as monarquias pelo apoio da burguesia ascendente. A isso correspondeu uma mudança na consciência filosófica ocidental, com reflexos na questão da valorização do trabalho e do tempo livre.

Os filósofos do Renascimento propõem uma nova perspectiva para a compreensão do homem, que não deve mais ser visto apenas como um sujeito contemplativo, teórico, mas um sujeito ativo, transformador e criador de seu mundo. A razão ocupa seu lugar como motor dessa mudança, pois ela permite não só entender a natureza, mas modificá-la de acordo com os interesses práticos do homem. Neste momento, os interesses práticos 
estão em íntima relação com os interesses econômicos de um determinado grupo social em ascensão enquanto classe: a burguesia. $\mathrm{O}$ nascente modo de produção capitalista impulsiona o desenvolvimento da Ciência e da Técnica, que reciprocamente o fortalecem. Em contraposição à exaltação do Divino, passa-se a uma exaltação do que é humano e, portanto, de tudo que é produzido pelo homem. Embora em um primeiro momento não se tenha retirado à contemplação sua posição de atividade superior, especialmente quando comparada ao trabalho manual, já há uma considerável redução na oposição entre trabalho físico e atividade intelectual, tão importante na Antiguidade em função das relações de classe. $\mathrm{O}$ trabalho passa a ser visto como uma espécie de preparação, um estágio necessário na passagem para uma função superior de contemplação.

A modificação decisiva da consciência relativa ao trabalho deveu-se, principalmente, ao movimento conhecido como Reforma.

E a situação só virá a modificar-se a partir de uma nova interpretação da Bíblia e de um movimento cultural burguês que aglutinou e articulou todas as manifestações artísticas, filosóficas e científicas, visando a justificar os valores e padrões sociais burgueses num todo coerente, em confronto com a sobrevivência dos valores medievais (Bacal, 1988, p.41).

Face à concepção sobre o trabalho ainda reinante, tornou-se imprescindível dar-lhe uma nova interpretação, transfigurando-o de atividade subalterna em missão atribuída por Deus. A medida do valor do homem deixa de ser o berço em que nasceu, passando a ser o seu trabalho.

Teólogos reformistas dedicam-se, agora, a formular uma ideologia enobrecedora do enriquecimento - conceituado como sinal de benesse divina - dignificadora do trabalho e condenatória das antigas atitudes senhoriais de ócio e fruição, bem como de sua contraparte popular, a mendicância (Ribeiro, 1972, p. 149).

A ética protestante passa a pregar valores como a diligência, a temperança, a parcimônia, o afastamento dos prazeres carnais e a poupança, valores esses em perfeita consonância com as necessidades do capitalismo ascendente. Surge assim uma nova consciência filosófica, em que o trabalho recebe um novo significado: o homem até então trabalhara para sobreviver, agora vai fazê-lo visando a obtenção de algo mais do que a simples satisfação de suas necessidades vitais: é a moral, é o que se deve fazer. A ociosidade é um mal e o trabalho se impõe como dignificante.

Seguindo a tradição dos filósofos iluministas e enciclopedistas, os economistas clássicos do século XVIII descobrem no trabalho toda fonte de riqueza das sociedades humanas. Colocando o trabalho como uma categoria central de sua análise da realidade, entretanto, a economia política (D. Ricardo, A. Smith) dissociava a transformação da natureza levada a efeito pelo trabalho humano de sua contrapartida, ou seja, a transformação ocasionada no homem pela modificação do ambiente que o cerca. A apreensão desta relação de das vias viria a acontecer com Hegel e, mais tarde em toda sua radicalidade, com Marx.

A abordagem marxista mantém o trabalho como categoria central da análise sócio-histórica da evolução do homem. Porém, de acordo com a visão de Marx, o trabalho assume um duplo caráter na sociedade capitalista: positivo, na medida em que de certa forma o trabalho criou o homem, constituindo-se em uma dimensão fundamental de sua personalidade, pois o caracteriza como ser humano; negativo, na medida em que nas sociedades de classe assumiu uma função alienadora: quando é despojado dos meios de produção, o indivíduo perde a perspectiva de exteriorização de si mesmo no mundo real, separado que está dos objetos que produz e em que produz-se.

O triste, porém, está no seguinte fato: assim como o trabalho se constitui na condição de realização da pessoa humana — onde ele se exterioriza e se dignifica -, assim também ele pode ser a fonte de degradação e exploração quando deixa de estar sob o domínio do homem. É o trabalho alienado (Guareschi, 1988, p. 33).

Para Marx, o homem como ser social que é, não distingue vida individual e vida social, já que uma reflete a outra. Se a vida humana é vida social e se manifesta em sua exteriorização através do trabalho, é forçoso admitir que quando o trabalhador não é dono de sua capacidade de trabalhar e nem daquilo que produz, não é dono de si mesmo. Em outras palavras, vendendo sua força de trabalho, vende-se a si mesmo, pois deixa de pertencer-se, de governar sua vida, que agora pertence a outro. $\mathrm{O}$ homem alienado é o oposto do homem autônomo, que é aquele que deve a si mesmo seu modo de existência. 
No modo de produção capitalista, o trabalhador não é visto como ser humano, mas como uma mercadoria, um objeto a ser consumido.

O que constitui a alienação no trabalho? Primeiramente ser o trabalho externo ao trabalhador, não fazer parte de sua natureza e, por conseguinte, ele não se realizar em seu trabalho, mas negar a si mesmo, ter um sentimento de sofrimento em vez de bem estar, não desenvolver livremente suas energias físicas e mentais, mas ficar fisicamente exausto e mentalmente deprimido. $\mathrm{O}$ trabalhador, portanto, só se sente à vontade em seu tempo de folga, enquanto no trabalho se sente contrafeito (Marx, 1984, p.104).

Há ainda um outro aspecto importante a ser mencionado quanto aos efeitos da alienação: sua repercussão na relação entre os homens. O modo de produção capitalista, a propriedade privada, a divisão social do trabalho, implicam necessariamente no estabelecimento de determinados tipos de relações entre os homens. A isto, Marx: denomina relações sociais de produção. Refere-se não apenas à maneira como se relacionam as pessoas dentro do processo produtivo, mas também às formas institucionais daí derivadas e que regulam as relações humanas propriamente ditas. O Estado, a Cultura, as instituições sociais são exemplos concretos da materialização das relações de produção. No capitalismo, as relações sociais de produção são caracterizadas pela desigualdade entre os homens. Um ser humano não é igual a outro ser humano (pela existência da propriedade privada e das classes sociais). Alguns indivíduos não tem valor, senão como mercadoria. Estabelece-se uma relação de dominação, onde a dimensão do econômico substitui a dimensão do humano. Entre os próprios trabalhadores fica perdido o sentido do coletivo, da cooperação entre iguais, cria-se uma estranheza mútua. As relações entre os trabalhadores tornam-se de certa maneira falsas, na medida em que são fundadas em uma ideologia que lhes é imposta.

Marx defendeu a limitação da jornada de trabalho principalmente por ser esta uma das dimensões da luta de classes e com argumentos de natureza puramente econômica, não porque atribuísse importância ao tempo livre em si mesmo. Ele acreditava que, em uma futura sociedade comunista, por não estarem obrigados a trabalhar para satisfazer suas necessidades, os homens realizariam esta atividade pelo interesse em descobrir suas próprias possibilidades. O trabalho não se realizaria então para receber um salário, senão que por ser a maneira pela qual os indivíduos conseguiriam desenvolver-se pessoalmente e contribuir para o enriquecimento material e social de toda a sociedade. A distinção entre trabalho e tempo livre perderia seu significado, uma vez que o trabalho não seria mais um meio de subsistência, mas se converteria em uma necessidade vital, a atividade produtiva se tornaria uma atividade lúdica.

Todos os demais autores que seguiram esta tendência, embora trazendo suas contribuições originais ou mesmo reformulando de maneira significativa a teoria marxista, não promoveram grandes alterações na ideia derivada de Marx sobre o duplo caráter do trabalho, sublinhando esta atividade como fundamental para a compreensão do ser humano e da sociedade, mas relegando a questão do tempo livre a uma posição marginal.

\section{Tempo livre e relações capitalistas}

O tempo livre, dentro do quadro das relações capitalistas, geralmente é encarado como uma compensação ao sofrimento imposto pelo trabalho e/ou como uma simples forma de reprodução da força de trabalho. Porém já há bastante tempo é mais do que isso: foi incorporado ao processo produtivo, àquilo que denominamos lógica da produção de mercadorias. $\mathrm{O}$ tempo, na sociedade capitalista, transformou-se em uma mercadoria que pode ser adquirida num mercado de bens simbólicos e consumida de acordo com as possibilidades de cada um. Estas possibilidades são, é claro, condicionadas pelas razões sociais do capital:

Os mecanismos de reprodução da sociedade induzem a um consumo passivo de bens e à atomização das relações sociais, tendendo restringi-las a conversas e encontros dentro do âmbito familiar ou pequeno grupo de amigos ou parentes. Aparentemente, estas práticas significam livre opção individual, mas efetivamente não se poderia esperar que o consumo do lazer restituísse aos trabalhadores a liberdade que lhes foi expropriada na esfera produtiva (Oliveira, 1986, p. 12).

Em função dessa realidade, alguns autores utilizam a expressão antilazer para designar as condições do tempo livre em sociedades como a brasileira. $\mathrm{O}$ antilazer seria a própria negação do lazer.

... simples atividades a serem consumidas, alimentando a alienação (Marcellino, 1986, p. 18) 
Em uma sociedade onde os indivíduos em sua maioria ainda não conseguem satisfazer necessidades básicas de sobrevivência, não existe liberdade a ser exercida no tempo livre.

Para a sociedade capitalista, o tempo livre deve ser um tempo necessário para que se possa consumir as mercadorias produzidas pelo sistema, tendo em vista manter uma certa estabilidade na relação econômica da produção e do consumo. Nesse sentido, a ideologia burguesa tem um papel preponderante sobre a utilização do tempo livre pelo indivíduo (Cavalcanti, 1986, p. 25).

A ideologia burguesa, aqui denominada lógica da produção de mercadorias, contribui para a passivização do trabalhador, para seu enquadramento dentro das condições sociais prescritas, obstaculizando a participação social para a produção da própria vida.

Sem dúvida, é a conformidade que tem predominado no atual modo de vida das sociedades capitalistas. Em inúmeras circunstâncias, o indivíduo parece ter perdido o sentido do valor e da dignidade de si mesmo. Essa perda tem provocado insegurança, fazendo-o buscar o alívio na conformidade, através da submissão à autoridade anônima (Cavalcanti, 1986, p. 27).

Um ponto a ser destacado, portanto, é a submissão das necessidades dos trabalhadores aos interesses da produção, bem como a criação de novas e falsas necessidades, principalmente através dos meios de comunicação de massas.

Um outro fator que promove a unificação e a integração da sociedade é a manipulação' científica altamente eficaz das necessidades. dos desejos e das satisfações. A manipulação científica, que opera muito vigorosamente na publicidade e na indústria da diversão, deixou de ser há muito tempo apenas uma parte da superestrutura; ela se tomou parte do processo produtivo de base e dos custos necessários de produção. Grandes quantidades de mercadorias não seriam adquiridas sem a sistemática e científica manipulação das necessidades e sem a estimulação científica da demanda (Marcuse, 1972, p. 195).

Assim, as necessidades dos trabalhadores são moldadas a partir da inculcação massiva de valores desvinculados de sua realidade concreta, tais como os símbolos de status ou prestígio social. Há uma intensa valorização do consumo, do ter, o que se reflete na esfera do tempo livre na necessidade de compra e consumo de bens materiais e simbólicos de alto valor de troca. Como a maioria da população não possui poder de compra, deve contentarse com o consumo de bens culturais de baixa qualidade e distantes de suas reais necessidades, o que contribui para aumentar a alienação.

Ao destacarmos a manipulação do tempo livre do trabalhador pela lógica da produção de mercadorias, contudo, não devemos desprezar sua dimensão potencial de resistência, e crítica a esse sistema alienador. Apesar de tudo, é em seu tempo livre que o trabalhador tem a possibilidade de desenvolver uma crítica de sua realidade cotidiana.

Porém, na realidade brasileira, e dadas as condições concretas de vida da maioria da população, a prática do lazer é muitas vezes, por si só, mais do que uma crítica, uma resistência cotidiana à lógica dominante na sociedade (Valle, 1988, p. 48).

Nesta linha, manifestações culturais populares espontâneas são criadas para fugir das regras impostas, resistindo à institucionalização, à desapropriação cultural e ao seu uso pelas classes dominantes para a atenuação dos conflitos sociais.

Considerando que o trabalhador é desapropriado de seu tempo, de parte significativa dos ganhos do trabalho social, materiais e culturais, da quase totalidade de suas energias físicas e mentais, a resistência oferecida no lazer e através do lazer assume a significação de uma luta de reapropriação, inconsciente e desorganizada, mas não menos real, de um espaço de liberdade (Valle, 1988, p. 49).

Assim, as festas populares e as práticas informais no carnaval e no futebol, enquanto manifestações ainda não hegemonizadas pela lógica dominante, podem ser encaradas sob esta perspectiva. Da mesma forma, fazem sentido as lutas desenvolvidas pelos movimentos sindicais autenticamente identificados com os interesses dos trabalhadores pela redução da jornada de trabalho.

O simples fato de libertar-se, ainda que temporariamente; da opressão do trabalho imposto pelo capital, das necessidades e obrigações da vida cotidiana, determina a construção do espaço mais livre que o trabalhador pode dispor. Explorar esse potencial de liberdade, no sentido de desvinculá-lo 
das relações trabalho/tempo livre consignadas pela lógica capitalista, significa ampliar as possibilidades de realização de uma sociedade mais humana.

O ócio, no sentido de tempo realmente livre de tudo, não é o "pai dos vícios" como sempre se proclamou, mas um direito natural do homem, que favorece sua liberdade como pessoa, pois o ócio é quem irá lhe dar o verdadeiro sentido da vida, que lhe permitirá elevar-se além da fixidez e do pesadelo de uma vida que se repete em seus esquemas de produção e consumo, para atender aos reclamos do capital-trabalho (Ribeiro Júnior, 1986, p. 46).

Concluímos com uma constatação: é realmente difícil resolver satisfatoriamente a contradição entre as dimensões crítica e alienadora do tempo livre para o trabalhador na sociedade capitalista. São faces opostas de uma mesma moeda, aspectos diversos de um mesmo fenômeno que devem ser levados em conta na interpretação da prática cotidiana do trabalhador.

Logo, o lazer, como automática liberação de tempo livre, para o divertimento ou descanso, é imprescindível para suportar o ritmo de vida imposto ao trabalhador; porém não significa que, com isto, o mesmo esteja liberto das amarras da moderna sociedade industrial, do consumo do supérfluo, do obsoletismo planejado da renúncia da satisfação imediata em nome do progresso, em nome da liberdade retórica do mundo capitalista (Silva, 1986, p.59).

\section{Referências bibliográficas}

BACAL, Sarah S. Lazer, teoria e pesquisa. São Paulo, Loyola, 1988.

CAVALCANTI, Kátia B. Tempo Livre, Lazer e Luta Ideológica. Reflexão, v. 11 ; n. 35,1986 , p. $24-32$

CODO, Wanderley, SAMPAIO José J. e HITOMI, Alberto. Indivíduo, trabalho e sofrimento. Petrópolis, Vozes, 1993.

GUARESCHI, Pedrinho e RAMOS, Roberto. A Máquina Capitalista. Petrópolis, Vozes, 1988.

LAFARGUE, Paul. O Direito à Preguiça. São Paulo, Kairós, 1983.

MARCELLINO, Nelson C. Considerações sobre valores expressos por autores brasileiros na relação lazer-educação. Reflexão. v. 11, n. 35, 1986, p. 15-23.
MARCUSE, Herbert. A Obsolescência do Marxismo, em Opções da Esquerda, Rio de Janeiro, Paz e Terra, 1972, p. 193-203.

MARX, Karl. Manuscritos de 1844, Buenos Aires, Cartago, 1984.

OLIVEIRA, Paulo de S. Tempo livre, trabalho e lutas sociais. Reflexão, v. 11, n. 35,986 , p. 7-14

PEREZ LEDESMA, Manuel. O trabalho torna as pessoas livres? Encontros com a Civilização Brasileira, Rio de Janeiro, v. 24, 1980.

RIBEIRO, Darcy. O Processo Civilizatório. Rio de janeiro, Civilização Brasileira, 1972.

RIBEIRO JÚNIOR, João. Algumas considerações sobre o ócio como lazer. Reflexão, v. 11, n.35, 1986, p.38-42.

SANCHEZ VASQUEZ, Adolfo. Filosofia da Praxis. Rio de Janeiro, Paz e Terra, 1986.

SÁVTCHENKO, P. Que é o Trabalho? Moscou, Progresso, 1987.

SILVA,Norma F.L. da. A dimensão ideológica do lazer. Reflexão, v.11, n. 35, 1986, p.57-61.

VALLE, Lilian A. B. do. O lazer como resistência. Fórum Educacional. v. 4, n. 12,1988, p.44-50. 


\section{Doença dos nervos: o ser trabalhador como definidor da identidade psicológica ${ }^{1}$}

\section{Maria da Graça Corrêa Jacques ${ }^{2}$ UFRGS/PUCRS}

O trabalho tem por objetivo propiciar uma reflexão sobre parte do cotidiano dos ambulatórios psiquiátricos, destacando a compreensão da doença dos nervos como uma queixa subjetiva que remete à identidade definitória do humano. O texto contempla uma análise a partir de três dimensões: associação trabalho/sofrimento presente na representação coletiva: os sintomas descritos por um trabalhador e a análise teórica com base na Psicanálise a partir dos trabalhos de Jurandir Freire Costa. A justaposição dessas três dimensões permite melhor articular e compreender o cotidiano dos ambulatórios que prestam serviços à classe trabalhadora.

A memória do trabalho é o sentido, é a justificação de toda uma biografia. Quando o sr. Amadeo fecha a história de sua vida, qual o conselho que dá? De tolerância para com os velhos, tolerância mesmo com aqueles que se transviaram na juventude: "Eles também trabalharam".

A escolha deste trecho para introduzir estas reflexões tem o objetivo de assinalar o valor conferido à capacidade de trabalho e ao ser trabalhador como elementos definitórios de grande significação na construção da identidade psicológica e na configuração do psicopatológico.

A questão da identidade reporta a pergunta Quem és? O cotidiano da resposta não traz certezas sobre seu conteúdo. Ao contrário. O emprego popular do termo é tão variado e o contexto conceptual tão amplo que, ao contrário de certezas, aponta para imprecisões.

O mesmo em relação ao trabalho, vocábulo controvertido desde sua origem etimológica. Remete a diferentes representações que expressam uma dificuldade em defini-lo tanto pelo senso comum como pela bibliografia especializada.

${ }^{1}$ Trabalho premiado com Menção Honrosa no Concurso "Histórias de Trabalho", promovido pela Prefeitura Municipal de Porto Alegre.

${ }^{2}$ Psicóloga, professora da UFRGS e PUCRS.

${ }^{3}$ Parágrafo final da obra de Ecléia Bosi "Lembranças de Velhos".
Portanto, estas reflexões não se reportam a elaborações teóricas sobre identidade (especialmente no campo filosófico) ou sobre trabalho. Focam a associação entre sofrimento psíquico e exercício laboral a partir de um recorte teórico com base na Psicanálise. Importante assinalar os limites das teorias na compreensão dos fenômenos. Teorias que, se em parte ajudam a entender o real enquanto objeto da ciência, não dão conta do real como um todo, ou ainda, não dão conta de todos os componentes deste real. Essas considerações são necessárias para justificar os limites deste texto e relativizar qualquer tentativa de compreendê-lo como exaurindo a temática.

Procuram se reportar ao cotidiano dos ambulatórios psiquiátricos onde há um convívio diário com pacientes que se autodenominam doente dos nervos. Esta denominação, em geral, desconcerta os profissionais que laboram nestas instituições pois não se referem às classificações nosográficas tradicionais difundidas nos cursos de Medicina e Psicologia. Estes cursos privilegiam as teorias clássicas que subestimam as relações de trabalho na gênese do sofrimento psíquico.

Assim, por exemplo, não chama a atenção que se tenha produzido tão pouco no campo da Psicologia sobre trabalho. Codo (1985) encontrou apenas 10 páginas a respeito em um manual de 5 volumes que percorre todas as áreas da Psicologia. Dejours (1988) ao comentar o subdesenvolvimento da Psicopatologia do Trabalho o atribuiu ao superdesenvolvimento das disciplinas tradicionais que ocultam aquilo que não pode ser articulado dentro de suas propostas. Erikson (1972) refere à prática comum entre os profissionais do campo psíquico de alterar as ocupações dos sujeitos para evitar a identificação sem considerar essenciais os dados característicos dessas ocupações.

Se as teorias clássicas ignoram a relação entre o cotidiano de trabalho e o sofrimento psíquico, a representação coletiva expressa esta relação, inclusive através da produção artística:

Vai trabalhar, vagabundo/ Vai trabalhar, criatura?

Deus permite a todo o mundo/ uma loucura/

(...)

Pode esquecer a mulata/ Pode esquecer o bilhar/

Pode apertar a gravata/ Vai te enforcar! 
Vai te entregar/ Vai te estragar/Vai trabalhar/

(...)

Vai terminar moribundo/ Com um pouco de paciência/

No fim da fila/ do Fundo da Previdência/

Parte tranquilo ó irmão/Descansa na paz de Deus/

Deixaste casa e pensão/ só para os teus/

(...)

Vai te entregar/ Vai te estragar/ Vai te enforcar/

Vai caducar/ Vai trabalhar/ Vai trabalhar... ${ }^{4}$

Os versos do poeta são uma entre as muitas expressões artísticas sobre a importância do tema trabalho no mundo contemporâneo. Embora cada artista interprete a seu modo, todos revelam, através de suas obras, uma representação coletiva que, ao mesmo tempo, aponta o valor positivo conferido ao trabalho e denuncia o sofrimento que lhe é associado. Sofrimento aceito e referendado a partir da consigna bíblica que imputa ao trabalho o castigo pela desobediência à ordem divina, mas que, também, confere ao humano sua distinção em relação à natureza e sua especificidade e centralidade no mundo natural.

Esta representação coletiva que se inscreve numa trama de significados elaborados socialmente emerge, também, através dos discursos em forma de queixas que cada trabalhador apresenta ao procurar os ambulatórios psiquiátricos. Representação que ao penetrar no psiquismo se articula com outros objetos presentes, acrescentando e sendo acrescentada de propriedades, transformando e sendo transformada (Lane, 1989, Moscovic, 1978).

O imbricamento entre o individual e o social, que a representação remete, se expressa no relato espontâneo de cada trabalhador que procura os ambulatórios psiquiátricos com queixa de sofrimento psíquico. Esta experiência cotidiana pode ser compreendida a partir de uma perspectiva

\footnotetext{
${ }^{4}$ Fragmentos da música de Chico Buarque "Vai trabalhar vagabundo".
}

teórica. É objetivo deste texto justapor estas duas dimensões e, após, tecer algumas considerações a respeito.

Eu sou um homem trabalhador... Porque eu sou trabalhador! Não é querer se gabar, mas não tem serviço que não vá! (...) Agora eu estou muito arrebentado, já, né. Estou com 48 anos, parece 50 e tantos. De tanto se judiar. (...) A nossa turma é uma turma parelha, uns homens tudo trabalhador e tudo homem bom. (Depoimento oral)

Para muitos desses homens ser bom trabalhador significa ser bom pai, bom marido, bom filho, bom amigo, bom vizinho, enfim, um bom homem pleno e realizado.

(...) É vadiação. Pessoa vadia que não quer trabalhar.(...) Que a pessoa que não quer trabalhar, eu acho que é preguiçoso. Ou é doente, uma coisa ela tem no corpo(...).

Nosso intuito é mostrar que o imenso relevo dado a sexualidade diminui de importância quando deixamos o espaço cultural das elites e entramos no universo da classe trabalhadora masculina(...) Ao lado da heterossexualidade, o componente capacidade de trabalho ou ser trabalhador também é um elemento definitório de grande significação (p.27).

Boto 3500,4000 peças que é para botar. Todo o dia, nas 8:45! Acendo um cigarro atrás do outro. Pau e pau! Então a produção sai todo o dia, né. O que pedem. A quantidade. Eu não me preocupo (...) Se não tem inteligência, não tem noção. Eu sou muito inteligente para máquina (...) Eu no serviço não prego para trás não. Qualquer tipo de serviço.

A identidade psicológica diferencia-se dos demais sistemas identificatórios por se apresentar ao sujeito como aquilo que não é apenas o atributo do meu eu ou de algum eu. Em outras palavras, é o sistema de representações que se mostra a consciência do sujeito como um predicado universal e genérico definidor por excelência do humano (p.22).

Quer dizer, tu só sai dali de cima da máquina que vai te esquentando a cabeça. Não é fácil! (...) Agora, querer esquentar a cabeça em cima

${ }^{5}$ São aqui transcritos fragmentos do depoimento de um trabalhador nomeado João da Silva, colhidos pela psicóloga Carmen Grisci, Na transcrição procura-se manter em parte a linguagem oral com o objetivo de mais fielmente expressar a vivência relatada. O texto teórico se refere a obra de Jurandir Freire COSTA, Psicanálise e contexto cultural. 
de máquina, não.(...) Claro, tu ficas nervoso.Aí já não dá certo. Aí tu já te ataca dos nervos. Aí, começa a quebrar ferramenta, saltar peça (...). Aí vai, teus olhos vão dispairando, aí tu sai dos nervos. Eu sou um que sou nervoso. Como aparece não sei. Às vezes é de graça, assim de varde. É de varde assim. É só não dar certo o serviço que te ataca os nervos. É só gritar comigo. (...) Cachorro brabo se tu conversar com ele se entende. Então, porque nós, que somos pessoas adultas, batizadas. Se não fosse batizada tá bem. Nós somos batizados. Chegar gritando...

Em contrapartida, sempre que pedíamos que procurassem falar um pouco de suas vidas, o que emergia espontaneamente ao relato era a trajetória profissional ou os percalços da vida laborativa. A doença dos nervos estava sempre relacionada ao trabalho (...) (p. 26).

(...) Eu tomei aquele veneno no quartel que eles deram. Eu servi em 61. Deram água para tomar lá, eu fiquei bem louco dos nervos. Eu estava servindo no tempo da Legalidade, não sei se tu te lembras? Eles deram dois vidros de água assim para tomar. Eu peguei para jogar fora. Não, tem que tomar na frente do doutor e do coronel. Dois vidros. Para dar coragem. Aí começa a tremer as carnes. Embola tudo, as veias aqui assim... É só atacar os nervos. Aí tem que fazer massagem nos braços, molhar as mãos para desenrolar as veias. A coisa mais ruim (...). Não adianta, não descobrem o veneno para abater aquilo.

Habituados a pensar a neurose como um desequilíbrio cuja psicogênese está nos conflitos familiares, afetivos ou sexuais, originados num certo tipo de infância, o terapeuta pode se desesperar quando se defronta com razões do tipo pancada na cabeça; desgosto pelo filho ingrato e marginal; desgosto com a filha que se perdeu; menstruação que não veio na hora, etc. (...) A doença dos nervos reflete a consciência da doença que não reproduz a ideia de causalidade hegemônica no imaginário psicoterápico (p.21).

(...) Vou me aposentar, se Deus quiser! Um ano e pouco. Insalubridade. A vida da gente é brava. A gente tremula bastante para viver.

A vida operária não é nem mais nem menos verdadeiramente próxima do inconsciente que a vida das elites e vice-versa. (p.29).

A justaposição dos dois depoimentos permite tecer algumas considerações.
O discurso de João da Silva informa sobre uma realidade objetiva, mas enquanto experiência vivida informa, também, sobre o mundo mental; é um discurso individual enquanto específico e pessoal e é um discurso coletivo revelador de representações similares e complementares presentes de diferentes formas entre os indivíduos.

Refere-se a uma representação de trabalho que outorga sua exaltação máxima e seu caráter enquanto obrigação moral. Representação que associa trabalho/doença a tal ponto que a falta de trabalho torna-se em si sinônimo da doença. Estas mesmas representações estão presentes no poema de Chico Buarque.

Quando refere aos sintomas apresentados que agrupa e classifica como doença dos nervos, João aponta para as situações do cotidiano laboral (sempre que há risco de não cumprir a produtividade esperada). No entanto, busca desvinculá-los deste cotidiano justificando seu aparecimento ao acaso e buscando atribuição causal em outras circunstâncias - referidas por Jurandir Freire Costa (1989) como ausentes do imaginário psicoterápico. Mas, se ausentes na produção teórica, estão presentes na representação coletiva sobre doença e são apropriadas como explicações plausíveis e próprias de uma lógica diferenciada da racionalidade própria do conhecimento científico.

No caso específico de João da Silva, a justificativa causal é buscada em outro espaço, o quartel; espaço, por excelência, de valorização dos atributos masculinos embutidos na representação de ser trabalhador: ser inteligente para trabalhar com máquinas, ser homem bom, não ser vadio. Assim, a identidade do ser trabalhador se constitui associada a atributos de valorização presentes na representação coletiva do que é trabalho, conferindo dignidade ao seu portador. Dignidade ameaçada sempre que situações concretas bloqueiam sua expressão. Então a doença, os sintomas.

Doença que justifica o não trabalho uma vez que a representação coletiva contempla a associação doença/trabalho como na canção anteriormente referida ("Vai te estragar/ Vai te entregar/ Vai trabalhar") e como no depoimento de João da Silva ("Agora eu estou meio arrebentado (...) a gente tremula para viver"). Assim, esta representação justifica manter incólume a identidade do ser trabalhador. 
Ainda, os estudos têm mostrado que os conflitos próprios da vida cotidiana associados ao trabalho, são vivenciados como conflitos internos pelos trabalhadores, como bem ilustra o depoimento do João. Portanto, justifica-se a busca de outras atribuições causais que eximem este cotidiano como causa do adoecimento. Justificativas que se inscrevem na perspectiva individualista e na ideologia do sucesso e do fracasso que lhe é associada a partir da qual os indivíduos são os responsáveis por suas ações e pela sua sorte, o que ilustra a imbricação da representação no ideário do capitalismo. Ideário presente no discurso oficial e no discurso do senso comum que atribuem os acidentes e doenças ocupacionais ou a uma questão de educação dos trabalhadores, qualificados como inseguros, indisciplinados e desleixados, ou a uma causa interna de caráter individual e geralmente de cunho orgânico.

Cunho orgânico que se expressa através das queixas presentes na doença dos nervos referendadas a um corpóreo: "veias que se embolam, olhos que vão despairando".

O objetivo deste texto foi o de propiciar uma reflexão a respeito do cotidiano dos ambulatórios psiquiátricos, destacando a necessária compreensão da doença dos nervos como uma queixa subjetiva que remete a uma essência de $e u$ - enquanto ser trabalhador que se inscreve na representação coletiva de trabalho/sofrimento a partir da consigna bíblica e que inscreve o sujeito no mundo humano o diferenciando dos demais seres da natureza. Conforme Engels (s.d., p.269):

O trabalho (...) é a condição básica e fundamental de toda a vida humana. E, em tal grau que, até certo ponto podemos afirmar que o trabalho criou o próprio homem.

Tanto é que são comuns referências a um tratamento desumano nos ambientes laborais associadas ao surgimento de sintomas psicológicos. João se refere a sua distinção em relação aos animais enquanto "pessoa adulta e batizada" e comenta que o tratamento "animal" que lhe é dispensado o "ataca dos nervos".

Para encerrar. O poeta diz: "Vai trabalhar vagabundo!" (embora tu te entregues, te estragues te enforques); o trabalhador diz: "a nossa turma é uma turma parelha, uns homens tudo trabalhador e tudo homem bom" (quem não trabalha ou é "vadio ou é doente"); o pesquisador diz que "ao lado da heterossexualidade o componente capacidade de trabalho ou ser trabalhador aparece como elemento de grande significação" (predicado universal e genérico definidor do humano).

Importante e necessário, portanto, incluir toda uma reflexão junto àqueles que trabalham nos ambulatórios psiquiátricos sobre a doença e o sofrimento psicológico, desvinculando-os de fatores genéticos ou falhas de personalidade em função de uma vida familiar pregressa como fatores exclusivos, e, contemplando o cotidiano do trabalho cuja organização e condições degradantes propiciam sofrimento a todos que cumprem a norma identificatória do ser trabalhador.

Como diz João da Silva: "a gente tremula muito para viver".

\section{Referências bibliográficas}

CODO, Wanderley. Saúde mental e trabalho: uma urgência prática. Psicologia, Ciência e Profissão, Brasília: CFP, n.2, 1988.

COSTA, Jurandir Freire. Psicanálise e contexto cultural. Rio de Janeiro: Campus, 1989.

DEJOURS, Christophe. A loucura do trabalho. $3^{\text {a }}$ ed., São Paulo: Cortez:Oboré, 1988.

ERIKSON, Erik Identidade; juventude e crise. Rio de Janeiro: Zahar, 1972.

ENGELS, Friedrich. Sobre o papel do trabalho na transformação do macaco em homem. In: MARX, Karl \& ENGELS, Friedrich. Obras escolhidas. São Paulo: Ômega, s.d., n. 2, p.267-282.

LANE, Silvia. O que é psicologia social. 15ª ed., São Paulo: Brasiliense, 1989.

MOSCOVICI, Serger. A representação social da psicanálise. Rio de Janeiro: Zahar, 1978. 


\section{O trabalho de iniciação científica e o sistema de produção capitalista: um paralelo entre a atividade de bolsista e o sistema de fábrica ${ }^{1}$}

Ana Cristina Garcia Dias Carla Dalbosco ${ }^{2}$

\section{Introdução}

A Ciência é uma atividade humana que está em constante mudança no decorrer da história e reflete as inúmeras diferenças entre aqueles que a pensam e realizam. É a própria dimensão humana da Ciência, a sua existência em contextos sociais e políticos, que a torna assim, completamente comprometida com o meio.

O conhecimento científico pretensamente neutro busca novos aportes e descobertas, mas apenas na medida em que estes não proponham mudanças estruturais, apenas mudanças que mantenham a estabilidade do sistema. É o tão falado mudar para não mudar. Adapta-se às condições externas a fim de manter internamente a posição de neutralidade e ausência crítica.

Torna-se relevante, então, pensarmos em nossos modelos de fazer Ciência. A própria divisão em áreas exatas e humanas reflete uma visão fragmentada de homem, seja entre o corpo e a alma, seja entre o pensar e o fazer. Segundo Patto, (1984) a Psicologia, longe de romper com a ideologia dominante, traz a esta última o apoio de seu aparato técnico e de seu arcabouço teórico, nascendo profundamente comprometida com uma demanda social e uma determinação ideológica específicas. De alguma forma, a Psicologia surgiu para atender às necessidades sociais de selecionar, orientar, adaptar e racionalizar, visando o aumento de produtividade. Para ser promovida à categoria de Ciência, a Psicologia sente necessidade de aperfeiçoar seu instrumental metodológico elaborando-o à imagem e semelhança das Ciências Naturais. Com isso, desenvolve-se uma tendência reducionista. Essa importação de modelos de

${ }^{1}$ Este trabalho teve resumo publicado no VI Salão de Iniciação Científica da UFRGS e nos anais da XXIV Reunião Anual da Sociedade Brasileira de Psicologia de Ribeirão Preto.

${ }^{2}$ Estagiárias de Psicologia do Trabalho do curso de Psicologia da UFRGS. Este trabalho foi realizado sob supervisão da professora Maria da Graça Corrêa Jacques. outras ciências instaura, a nível teórico-conceitual, na Psicologia, uma analogia entre meio natural e meio social e abre caminho à ideologia adaptacionista como concepção norteadora da ação do psicólogo, colocando-o no mesmo nível da ideologia política dominante. A análise das relações entre homem e sociedade mascara a existência de classes, da ideologia e do poder e exclui, metodologicamente, a dimensão histórica dos fatos sociais. Portanto, a finalidade do trabalho do psicólogo é a racionalização do comportamento do indivíduo no meio social, em função dos próprios interativos sociais, valendo-se das noções de condicionamento e de aprendizagem como mecanismos constitutivos do comportamento.

A Psicologia torna-se, então, mais um instrumento para alienação do homem, além de tornar-se a si própria um arcabouço alienado. Essa apropriação dos modelos de ciências exatas a distancia de seu objeto, o homem.

Se pensarmos na instituição universitária, ela se torna uma usina que fabrica modelos, modelos pautados pelas relações sociais. As experiências que visam propiciar interação teoria/prática (estágios, familiarizações) demonstram claramente como há um distanciamento entre o que está sendo estudado e o que é a atividade prática. Talvez possamos encontrar, dessa forma, um modelo taylorista (onde ocorre uma dissociação entre a concepção e a execução) transposto para a educação universitária.

Decca (1982), em seu livro $O$ nascimento das fábricas, demonstra como a interposição da figura do negociante entre o mercado e a produção artesanal representou um momento no qual se impôs a esta produção a figura indispensável do capitalista, criando-se uma hierarquia social sem a qual o próprio processo de trabalho fica impossibilitado de existir. Nessa divisão social, tornou-se imperiosa a figura do capitalista no interior do processo produtivo, e o trabalhador ficou distante do mercado.

Realizando uma transposição para o modelo de pesquisa, podemos presumir que a figura do orientador é indispensável ao processo, uma vez que este detém o saber e a autoridade sobre a produção acadêmica, e sem essa figura fica vetado aos alunos uma inserção à área da pesquisa científica. 


\section{Problemática estudada}

Os pesquisadores buscam pensar a realidade e produzir conhecimentos sobre esta.

Não podemos nos esquecer que a produção científica, como toda produção, tem um objetivo. Ela está a serviço de alguém e alguém a financia; portanto, é impossível pensarmos numa produção neutra, desvinculada de interesses econômicos.

Como se produz? Por que produzimos? O que é feito com esse saber?

A partir de um determinado discurso que encontramos em nosso meio universitário sobre a produção do conhecimento como fator básico para nossa formação profissional, ficamos nos questionando acerca da prática vivenciada como bolsistas de iniciação.

Observamos que o capital, através do seu modelo de produção, estabelece relações que produzem uma incapacidade do pensar. Os modelos já estão dados, e toda proposição nova passa por um cerceamento social.

Em que medida um bolsista de iniciação científica, cujos objetivos de seu trabalho são o de uma apreensão global teórica e prática — do processo pesquisa atinge seus objetivos?

O universitário não está reproduzindo as demais relações existentes em nosso sistema produtivo e, consequentemente, reproduzindo as relações de poder estabelecidas entre patrão e empregado? E, pode-se pensar ainda, em que medida um pretenso conhecimento teórico possibilita ao bolsista o reconhecimento de sua produção? Essas relações estão sendo pensadas no meio acadêmico? É o bolsista senhor de sua produção? Como sua atividade criadora pode estar espelhada em seus trabalhos, uma vez que devem submeter-se a esse cerceamento vigente dado pelo orientador? $\mathrm{O}$ fato de a Psicologia inspirar-se no modelo das ciências exatas não torna mais dissociada a atividade de bolsista de iniciação científica? Como estão essas relações na área das ciências exatas?

Buscando refletir sobre essas questões, entrevistamos 6 estudantes universitários engajados em algum projeto de pesquisa ( 3 do curso de Psicologia e 3 do curso de Matemática Computacional). Todos recebiam auxílio financeiro pela realização de suas atividades.
As entrevistas foram gravadas e tinham um roteiro preestabelecido a partir das questões norteadoras do estudo. Os discursos coletados foram analisados a partir de princípios da metodologia proposta por Pagés e colaboradores (1990), em que se privilegiou a divisão em unidades intencionais de discurso, agrupados em temas emergentes e rubricas propostas pelas questões norteadoras.

$\mathrm{Na}$ análise que apresentamos a seguir, procuramos compreender as temáticas a partir de um recorte teórico que aqui denominamos considerações a partir das entrevistas.

\section{Considerações a partir das entrevistas}

Ao pensarmos na atividade de pesquisa, tal como é praticada em nosso meio acadêmico atualmente, a divisão do trabalho intelectual e braçal fica explícita. O bolsista caracteriza-se por desenvolver atividades que correspondem às atividades manuais $\mathrm{e}$, ao orientador, cabe $\mathrm{o}$ planejamento e concepção do trabalho.

A atividade de pesquisa é referida como algo difícil tanto a nível teórico como prático. É um tipo de atividade que possui características próprias. Também o processo de produção, atualmente, é algo difícil de ser compreendido, é uma coisa complexa, da qual não se possui um domínio. No depoimento abaixo fica claro que a entrevistada não tem domínio de sua produção e nem do seu produto. O reconhecimento de sua produção é difícil, embora essa ocorra.

A produção, ela é em conjunto, muitas vezes ela é até oculta (...) vai
se produzindo aos pouquinhos, quando tu vês tem alguma coisa
acabada. E até tu não sabes onde está a tua parte, às vezes, nessa
produção. Mistura tanto que tu não consegue, ah, tá lá uma
partezinha do que eu fiz (Miriam, Psicologia).

A própria atividade de pesquisa é vista como algo complexo e diferenciado de outras formas de trabalhos. Não há um reconhecimento imediato, e a expressão desse reconhecimento no produto é difícil de ser expresso.

(...) é um trabalho de pesquisa que, por si só, acho que é uma um pouco diferente. Pesquisa, prá um monte de gente, é uma coisa inútil. Porque é um descaso. É um descaso com a pesquisa. (...) Quer dizer, 
ninguém acha que tem muita utilidade, tudo tem muita utilidade. (...), a gente faz a maioria das coisas são conhecidas, mas porque a gente não tem conhecimento prá fazer uma coisa que é genial. A gente tá, a gente é aluno de graduação. Às vezes, modifica um pouco, ou tenta rodar no computador pior ou melhor, prá ver o que que dá. Então, às vezes, sai alguma coisa razoavelmente útil, né (...) (Celso, Matemática Computacional).

Alguns bolsistas sentem dificuldade em ter uma noção do conjunto da pesquisa, de como suas atividades se inserem num contexto maior. $\mathrm{O}$ seguinte depoimento ilustra esse ponto:

Bom, como eu disse, eu trabalhei bastante em esquemas numéricos. Tá, tá um pouco relacionado. Trabalhei um pouco com aplicações em dinâmica de fluidos, também tá um pouco relacionado. Mas entende, eu realmente, isso que tu perguntou a pouco, essa ideia de ver como as coisas se articulam, realmente eu não tenho (Jefferson, Matemática).

É interessante constatarmos como há desapropriação do conhecimento. Muitas vezes, há uma ideia do que é fazer pesquisa antes de inserir-se na mesma, o que não coincide com que ocorre depois que dela se participa:

Eu achava que (pesquisa) era uma coisa assim que tinha início, meio e fim. Que eu entraria numa pesquisa né, conheceria bem toda a pesquisa, a pessoa que tá fazendo a pesquisa, entraria em contato com ela, o que ela tava querendo, os objetivos que ela tem. Trabalharia não digo do início ao fim, mas pelo menos ter uma certa ideia, de onde eu trabalhasse, que que eu tava fazendo do início ao fim daquela pesquisa (Miriam, Psicologia).

No depoimento de Miriam, essa situação está bem caracterizada ela não consegue se identificar, nem identificar a sua produção no conjunto do processo.

Aqui, fica explícita uma expectativa de conhecer bem todas as etapas do processo, de que a tarefa seria um conjunto de práticas que lhe possibilitariam um melhor entendimento do conjunto total.

Entretanto, o que se observou é que não há uma continuidade da atividade. A fragmentação desse processo não permite ao sujeito vislumbrar como os dados empíricos, no caso da pesquisa, são base para as abstrações teóricas resultantes.

Tal como no sistema de fábrica, mais especificamente comparando ao modelo taylorista, não se tem a visão do processo como um todo. A fragmentação das atividades ocorre a tal ponto que a matéria-prima se transforma em outro produto, por vezes por um processo mágico, na visão do produtor. Tanto o produto como o processo são vistos como estranhos ao produtor. Toma-se necessário um esforço para que ocorra esse reconhecimento.

Também fazendo outra analogia ao modelo de organização do trabalho, o aluno tem momentos específicos em que se dá o aumento de sua produção. Parece que a atividade científica se sujeita às demandas do mercado - no caso, do meio acadêmico. Para o aluno, o final do semestre é um momento de aumento da produção, quer seja através de provas e trabalhos, quer seja através das demandas da atividade científica. Então, por não cumprir uma carga horária determinada durante o semestre, o aluno sujeita-se a essa demanda sem um maior questionamento.

A alienação ocorre quando o homem não consegue se apropriar da subjetividade incutida no produto, não se reconhecendo no mesmo. Este torna-se, então, estranho ao trabalhador, sendo visto como um poder independente de quem o produziu (Marx, 1989).

Os bolsistas se engajam, nessas atividades, visando a aquisição de um saber, de um enriquecimento de currículo e de uma remuneração, uma vez que cumprir todas as exigências acadêmicas concernentes ao curso os impossibilita de procurar um outro trabalho fora do meio acadêmico devido ao tempo a ser despendido em tal ocupação.

Sabemos que a bolsa de iniciação científica tem um valor para quem deseja prosseguir em uma carreira acadêmica, serve como currículo e experiência. Ser bolsista, para quem almeja continuar carreira acadêmica, em analogia ao sistema de produção capitalista, é ser mão de obra já "especializada" (no sentido de que já se conhece uma parte do processo, não se parte do zero).

O bolsista é uma força de trabalho que se submete à supremacia do capital simbólico, além do real. Podemos fazer uma analogia entre o capital-moeda e o capital-conhecimento. O conhecimento, tal como a 
moeda, acaba se transformando em um fim em si mesmo, autorreproduzindose. Vemos, então, que há um paralelo entre o acúmulo de riquezas e o acúmulo de conhecimentos. Um dos principais motivos que levaram os estudantes desses cursos de graduação a tornarem-se bolsistas foi a busca pelo conhecimento que é adquirido através da bolsa de iniciação.

O meu interesse bastante inicial foi curricular, mais que pelo salário, eu até tinha interesse em trabalhar. (...) já tinha o interesse de trabalhar em bolsa e até, se fosse necessário, ser voluntária, trabalhar de graça, eu tava interessada, eu queria aprender como é que se faz pesquisa, esse era o meu interesse e só (Miriam, Psicologia).

Podemos constatar, em todos os depoimentos, que a atividade de pesquisa era algo almejado, a qual seria realizada mesmo que não houvesse remuneração para tanto. O capital, além de simbólico, é também considerado, objetivamente, um capital-moeda. Observa-se, em alguns casos, considerações referentes a essa questão, na medida em que é afirmado pelos bolsistas que esse trabalho possibilita uma obtenção de algum dinheiro para gastos pessoais.

(...) Eu queria ser bolsista, em primeiro lugar, porque já é um... tu estuda por fora, ganha mais conhecimento e ganha um dinheirinho (Celso, Matemática).

A busca pela atividade de iniciação é relatada por alguns como a oportunidade de se poder entrar em contato com uma atividade prática na área de escolha profissional. Aqui, há a busca do resgate do saber como um todo, que não dissocia a prática da teoria.

Entretanto, como podemos ver, isso não é o que de fato ocorre. $\mathrm{O}$ estudante tem uma oportunidade de aprofundar outras áreas de conhecimento ainda distantes de uma aplicação prática. O conhecimento, tal como o capital, é uma mercadoria valiosa a qual justifica a exploração.

Então eu participei de todas as etapas da pesquisa, eu não fui usada assim como mão de obra (...) A gente trocava. E foi muito válido em termos de aprendizado. Que eu não me senti usada assim como mão de obra, que é o que eu vejo muito bolsista falar. Vejo que tem um, muitas pessoas que dizem que participam de um monte de pesquisas e não ficam em nenhuma. (...) Claro que a gente é usado, mas que não é só isso. Que a minha bolsa não serve prá aprender catar sujeitos, que não é isso que... O que eu acho é que tem realmente um aprendizado de pesquisa. (...) E isso vem da própria bolsa, que é uma bolsa que exige que tu faças e o orientador só te supervisiona. Tu não coleta dados e dá prá ele trabalhar (Débora, Psicologia).

Vemos, aqui, Débora comparando a atividade de pesquisa com o trabalho, enquanto sofrimento.

A bolsista constata que existem situações em que observa uma dissociação evidente da prática e do aprendizado a que a bolsa se propõe. Ao mesmo tempo, ela afirma que há, realmente, uma exploração, sentindose usada de certa maneira.

Cremos ser muito significativo esse depoimento, na medida em que nos demonstra que o sujeito incorpora essa mentalidade capitalista, uma vez que, aqui, há um assujeitamento a esse "ser explorado" em troca de um saber, que é proporcionado pela atividade de iniciação científica.

O conhecimento, ao mesmo tempo, que é capital, é também mercadoria a ser consumida por esses estudantes, fechando-se, assim o ciclo de produção e consumo capitalista, viabilizando a exploração do sujeito.

Além do capital, o tempo acabou servindo como uma arma em cima da qual se moldou toda estrutura social de trabalho, principalmente o sistema fabril.

$\mathrm{Na}$ atividade científica, o tempo tem uma conotação diferente. É claro que há o ritmo estabelecido, pois existem prazos a serem cumpridos, o orientador tem de prestar contas das atividades realizadas pelo bolsista etc. Mas há uma maior permeabilidade, não há tanta rigidez na questão de horas de trabalho como em outras atividades em geral.

Tanto os bolsistas da Psicologia quanto os da Matemática dizem não ter uma cobrança em relação a horas semanais. Há uma convenção de que seriam 20 horas semanais de trabalho, mas esse tempo varia muito em relação à época do semestre e à quantidade de atividades. Talvez, dessa situação, decorra a dificuldade de verem o seu trabalho associado a uma atividade empregatícia formal e até de categorizá-la como um emprego.

Embora se perceba, nesse discurso, uma referida liberdade de agenciamento do tempo empregado na execução das tarefas pertinentes à bolsa, foi possível verificar que não há um real controle que possibilita o domínio do tempo empregado. Constata-se isso nos discursos através de um 
controle externo que é dado ou pelo período do semestre em que se está (férias, período antecedente a apresentação de trabalho) ou mesmo da distribuição das tarefas. Observe os depoimentos:

(...) É tu não saber como é o teu tempo ali dentro. Tu não tem como gerir isso, tu mesmo. Ah, hoje eu vou trabalhar tantas horas aqui dentro (...) tu pode até pode entrar na sala né, mas tu não tem o que fazer. Para fazer o que lá dentro? Tu fica esperando que alguém te chame. Olha, tem isso e isso prá fazer até o dia tal, dai tá. Aí sim, tu te organiza. (...) (Miriam, Psicologia).

(...) Eu tinha que ficar lá na sala, o tempo todo, esperando aparecer os alunos. Aí não gostava muito daquilo. Achava perda de tempo, achava que ele devia estar me orientando para eu estudar mais matemática, e não ficar ali esperando os outros aparecerem. (Jaqueline, Matemática).

Segundo Decca (1982),

introjetar um relógio moral no coração de cada trabalhador foi a primeira vitória da sociedade burguesa, e a fábrica apareceu desde logo como uma realidade estarrecedora onde este tempo útil encontrou o seu ambiente natural, sem que qualquer modificação tecnológica tivesse sido necessária. (p.10)

O trabalhador, como no caso o bolsista, passa a introjetar e reproduzir o modelo de produção dado.

É que já conversando uma vez com ele (orientador), ele era uma pessoa que, ele é também um outro professor que tem aqui, disseram assim, que eles procuravam e estudavam sozinhos, não precisava chegar um professor e dizer, pega esse livro e estuda. Eles iam na biblioteca e procuravam o livro para fazer o exercício sozinho. Ninguém precisava mandar. E eu disse que a maioria das pessoas não são assim, precisam alguém chegar e cobrar um pouco. Eu preciso um pouco de cobrança, se não me cobram, eu vou adiando. Assim como eu, a maioria das pessoas que eu estou convivendo precisa, se não forem cobradas vão adiando, adiando, adiando e, quando vão ver, tem tanta coisa, acumulou tanto que não conseguem mais colocar as coisas em dia (Jaqueline, Matemática Computacional).

Alguns bolsistas se veem tão inseridos neste modelo, que não conseguem trabalhar, caso não sejam "cobrados".
Foucault (1979) diz que o poder moderno não é mais, essencialmente, uma instância repressiva e transcendente, mas uma instância de controle, que envolve o indivíduo mais do que o domina abertamente.

As relações entre o orientador e o bolsista são calcadas numa pretensa liberdade do segundo em relação ao seu trabalho (escolha de horários etc.), mas, invariavelmente, em maior ou menor grau, o bolsista sempre estará em função dos interesses do orientador. Vemos isso nos depoimentos abaixo:

(...) Depois, no outro ano, comecei a pegar outro projeto, pegar esses temas, pega um determinado tema sempre em torno da proposta inicial. Repito que é a que está lá no projeto da bolsa de iniciação científica. Para você pedir uma bolsa de iniciação, você tem diretrizes ali (Jefferson, Matemática Computacional).

(...) Ela dá uma liberdade muito grande prá ti trabalhar. Existe uma cobrança, é óbvio, mas a relação, assim que tu tem a bolsa, e ela tem que prestar contas do trabalho que é feito em função disso. Porque ela é a coordenadora, ela é orientadora, a bolsa é dela, o projeto. (...) então isso ela nos cobra, esses resultados que ela precisa mostrar, mas ao mesmo tempo, como a gente vai colher esses dados, como a gente vai desenvolver o projeto, ela nos dá uma liberdade muito grande.(...) Então, de alguma forma, todos os projetos tem que estar vinculados a este projeto maior, que engloba esses subprojetos (Diogo, Psicologia).

Há uma proposta de trabalho, sempre em função de algo anterior, um assunto do interesse do orientador, um assunto para o qual a verba de pesquisa foi destinada. Observamos que o próprio bolsista justifica toda essa estrutura sob a qual a pesquisa está apoiada. Essa estrutura é dada como natural, não ocorrendo maiores questionamentos. A liberdade de escolha do método é tida como um mérito do orientador; o mesmo podemos ver na colocação abaixo, na qual a possibilidade de discussão de ideias é tida como uma possibilidade vantajosa, não como um direito natural.

(...) Claro, o projeto era dele, só que teve muita troca assim, tinha discussão, não é uma coisa assim, ele te dá e tu faz (...) eu me senti trocando ideias, claro que não é assim, de igual para igual, mas com chance de colocar as coisas que eu penso (Débora, Psicologia). 
A dominação e o controle se dão também a nível mais objetivo com a explicitação dos mecanismos de dominação. Assim sendo, o professor/orientador vale-se de sua posição hierárquica para exercer toda a autoridade que lhe é atribuída. Isso é expresso nos depoimento abaixo:

Mas claro que tem essa relação com o que sabe mais, de um que te supervisione, de um que te controle (Débora, Psicologia).

Ah, este professor tinha um lance assim, quando eu larguei a bolsa, ele me falou assim, eu quero perguntar para o teu próximo orientador se tu é uma boa... uma boa... Não, não, porque nós simplesmente nos pegamos. E todos os alunos quase meio que foram assim, teve um rapaz que ele disse 'se tu não entregar o programa que eu pedi pra tu fazer, eu vou dar um parecer desfavorável para ti na Fapergs' (Jaqueline, Matemática Computacional).

Aqui apresentamos algumas temáticas presentes nos discursos colhidos. Outras tantas poderiam ter sido consideradas, visto a riqueza do tema.

\section{Conclusões}

Nosso objetivo, neste estudo, foi estabelecer uma relação entre as atividades desenvolvidas pelos bolsistas nos cursos universitários e o modo como o trabalho é organizado na sociedade atual, inspirado no Sistema de Fábrica (Decca, 1982).

Segundo Albornoz (1987), o processo de trabalho é uma atividade dirigida com o fim de criar valores-de-uso, de apropriar os elementos naturais, as necessidades humanas; é a condição necessária da vida humana. Mas, muitas vezes, o trabalhador não consegue ver onde pode ser enquadrada a sua produção. É um produzir para quem?

Dentro do espaço acadêmico, o bolsista não produz para si, mas está a serviço de uma organização maior, a própria atividade científica. Isso se dá de forma similar ao que ocorre na fábrica, onde o operário não produz para seu uso pessoal, mas sim para o capitalista que representa a instância última determinante das normas de produção.

$\mathrm{O}$ orientador representa, metaforicamente, o capitalista enquanto gerador e detentor da mercadoria.
Vemos, aqui, que o saber é, ao mesmo tempo, o produto e a mercadoria, que o bolsista busca, incessantemente, dentro do meio acadêmico, querendo, também, tornar-se possuidor desse valioso conhecimento, que dá status e posição.

Ele próprio, tal como o operário, embora detenha determinado saber, tem pouca consciência desse saber. Pois o saber, tal como o produto, é propriedade do capitalista, não de seu produtor imediato. Assim sendo, o produtor vai em busca de um determinado produto - no caso, o saber que é, como vimos, manipulado e determinado pelo capitalista.

O bolsista não sabe sequer para quem produz. Nos cursos aqui investigados, não se percebe maiores questionamentos acerca dos objetivos e funcionalidade de cada tarefa. O conhecimento é visto como algo externo a ser buscado, não construído. O orientador sabe mais, é alguém que pode lhe passar o conhecimento almejado, e a bolsa é o caminho para essa obtenção. Entretanto, em alguns momentos, esses bolsistas se veem como mero tarefeiros, não como construtores/produtores de conhecimento.

Da mesma maneira que há uma subordinação do trabalho ao capital, há certa subordinação da atividade de pesquisa à necessidade de produção científica do saber. Assim como o trabalhador trabalha sob o controle do capitalista, a quem pertence o seu trabalho, também o bolsista vive um tipo de relação semelhante. Por maior autonomia que os bolsistas revelem no modo de realizarem o seu trabalho, estão, invariavelmente, subordinados à linha de pesquisa do orientador, produzindo de modo a ampliar áreas que são de interesse do próprio orientador, que é o único que detém o conhecimento geral sobre o que está sendo realizado.

Portanto, são as relações de poder que tomaram conta do espaço acadêmico, passando a reproduzir as formas hegemônicas presentes na sociedade. A ciência corre o risco de cair nessa parcialidade - diríamos, até, nessa estagnação.

Os modos de se fazer ciência devem ser constantemente discutidos, a fim de evitar que se recaia numa medíocre reprodução e repetição dos padrões sociais já estabelecidos. 
A partir da realização deste trabalho, foi possível obter um melhor entendimento sobre o papel que tanto os bolsistas da Psicologia, quanto os da Matemática, ocupam na reprodução do modelo hegemônico.

Observou-se uma série de pontos em comum entre os dois grupos, o que reflete uma visão de mundo que está acima de qualquer diferenciação de área de trabalho. Essa visão, que consiste na reprodução do modelo social, abarca todo o sistema universitário (incluindo bolsistas e orientadores), tanto nas chamadas áreas exatas quanto nas áreas humanas.

Essa semelhança foi efetiva nos dois grupos, aparecendo mais claramente na questão da separação entre trabalho manual e intelectual e uma evidente dominação que se estabelece a partir do orientador como sendo a figura que detém o poder.

$\mathrm{Na}$ Psicologia, isso fica um pouco amenizado na medida em que há uma efetiva preocupação com a aplicação do saber, do uso da bolsa muito mais como um veículo de aprendizagem do que como um meio de trabalho. Também uma preocupação social característica das Ciências Humanas ameniza um pouco essa questão. Os bolsistas da Psicologia, talvez, realizem maiores questionamentos acerca de seu papel e envolvimento no tipo de pesquisa.

Já na Matemática, é mais difícil obter essa noção, aparentemente porque a dissociação é maior entre a pesquisa e sua aplicação. Apesar de os bolsistas também procurarem a bolsa com o intuito de aprendizagem, eles demonstram não ter muita ideia de como esse conhecimento pode servir socialmente, ou então têm ideias genéricas acerca das aplicações de seus conhecimentos de bolsa. Neste grupo, foi mais enfatizado que a bolsa de iniciação era um estímulo para permanência no curso, além, também,de ser uma complementação do currículo. Nela, o aluno tem chance de aprender coisas que não verá no curso de graduação.

A dificuldade de caracterizar a bolsa como trabalho ficou clara em ambos os grupos, demonstrando que a noção de trabalho ainda não é um construto fechado, estanque. Realmente não pode ser tomada como um emprego, pois a remuneração não é o principal objetivo, embora seja considerada. Todos os bolsistas enfatizaram mais a questão de aprender a realizar uma pesquisa, demonstrando claramente que essa aprendizagem é importante para prosseguir numa carreira acadêmica.
Não se pode esquecer que a Ciência está intimamente ligada ao contexto social e político da sociedade, não podendo ser vista sem uma aproximação deste. A Ciência é mais um instrumento na construção da história da sociedade, o que possibilita traçar paralelos entre as atividades do bolsista e do operário. O que mais os diferencia é a qualidade de seu produto.

O atual contexto histórico está a clamar por mudanças, as quais devem surgir dentro do próprio processo de produção, seja na fabrica ou na academia. Talvez isto se torne possível quando houver um questionamento de como se estabelecem as relações de poder nas próprias bases da produção científica. Somente se efetivarão mudanças a nível social no momento em que se tornar claro a serviço do que, como e para que são empregados determinados métodos. O próprio bolsista deve ter claro o papel que ocupa nessa reprodução do modelo hegemônico, tentando vislumbrar que objetivos tem e a quem serve o fluxo de seu trabalho.

\section{Referências bibliográficas}

ALBORNOZ, S. O que é trabalho. SP: Brasiliense, 1987.

DECCA, E. O nascimento das fábricas. SP: Brasiliense, 1982.

D’OLIVEIRA, M.M.H. Ciência e pesquisa em Psicologia. SP: E.P.U., 1984.

FOUCAULT, M. Microfísica do Poder. RJ: Graal, 1989.

JACQUES, M G. C. O contexto histórico como produtor e produto do conhecimento: trajetória da Psicologia do Trabalho. Psicologia: Reflexão e Critica. PoA, V.4, n.1/2,1989.

JAPIASSU, H. Introdução à epistemologia da Psicologia. RJ: Imago,1982.

MARX, K. O Capital: Critica da Economia política. $13^{\mathrm{a}}$ ed. RJ: Bertrand do Brasil, 1989.

PATIO, M.H. Psicologia e ideologia. SP: Queiroz, 1984.

RAGO, L.M \& MOREIRA E.F.P. O que é Taylorismo? $6^{\mathrm{a}}$ ed. SP: Brasiliense, 1984. 


\section{Saúde mental e trabalho: reflexões a partir de estudos com trabalhadores afastados do trabalho por adoecimento profissional}

Jaqueline Tittoni UFRGS e FAPERGS

Henrique Caetano Nardi UFRGS e $C N P q$

\section{Introdução}

A temática Saúde Mental e Trabalho é, sem dúvida, uma questão contemporânea. Presente na produção de conhecimento brasileira de forma sistematizada, principalmente, a partir da década de oitenta, tem sido abordada sob diversos enfoques. Enfatizando o estabelecimento de nexos causais entre a sintomatologia de origem psi (Silva, 1987) e as condições e a organização do trabalho ou ressaltando as experiências e vivências do trabalhadores no seu cotidiano de trabalho, as questões relativas à subjetividade e à saúde mental estão presentes em estudos com trabalhadores de vários setores produtivos.

Do mesmo modo, a possibilidade de abordagem desta temática sob vários aspectos, dado a complexidade do objeto saúde mental e trabalho, impõe a integração de várias áreas de conhecimento, na sua análise. Tal fato instaura este campo como marcado pela interdisciplinaridade.

De certo modo, estudar Saúde Mental e Trabalho é sistematizar algo do cotidiano dos trabalhadores, desde muito, presente na sua trajetória e cristalizado em modos de ser, muitas vezes, referenciados no seu trabalho. $\mathrm{O}$ olhar acadêmico e a produção de conhecimento científico sobre suas experiências busca, sobretudo, práticas efetivas que possam se fazer presentes na melhoria das condições de trabalho e no estabelecimento de políticas públicas.

O estudo sobre trabalhadores afastados do trabalho por adoecimento profissional traz uma série de reflexões para a análise da Saúde Mental e Trabalho, principalmente no que diz respeito ao caráter dualista presente nas concepções correntes em saúde do trabalhador. Esse caráter se expressa, em nosso estudo, nas dualidades saúde-doença e trabalho-não trabalho.

$\mathrm{Na}$ verdade, a experiência dos trabalhadores não ocorre de forma "dualista", mas seus modos de representá-la expressa estas dualidades. Isto porque existe um saber legitimado sobre saúde-doença e sobre trabalho-não trabalho, que as concebe como polaridades e dualidades e ao qual os trabalhadores recorrem para compreender sua própria situação.

Este saber constrói o "discurso médico" (Foucault, 1987), como um saber investido de poder que reconhece e legitima a doença. Este discurso funda o espaço da clínica como

ao mesmo tempo, um novo recorte das coisas e o princípio de sua articulação em uma nova linguagem, na qual temos o hábito de reconhecer a linguagem de uma "ciência positiva" (Foucault, p. XVII, 1987).

Assim, trata-se de refletir sobre o modo como a construção de um discurso sobre saúde-doença, trabalho-não trabalho implica num estatuto filosófico de homem, articulando, também, saúde à normalidade e doença à anormalidade.

As consequências deste discurso para os trabalhadores afastados do trabalho por adoecimento profissional recai nas dificuldades encontradas para o reconhecimento e a legitimação de sua situação de adoecimento como sendo profissional, ou seja, como tendo sua gênese nas condições penosas da organização do trabalho, conforme veremos ao longo desta exposição.

Outro aspecto introdutório remete ao fato de que a situação de adoecimento não pode ser tomada isoladamente, mas quanto a seu caráter de descontinuidade na trajetória de vida dos trabalhadores, pois o adoecimento coloca em questão suas práticas cotidianas e seus projetos de vida.

Assim, nosso recorte da problemática saúde mental e trabalho analisa os processos históricos e sociais em questão nas concepções da saúde-doença e trabalho-não trabalho, buscando sua referência na experiência dos trabalhadores afastados do trabalho por adoecimento profissional. 
Para tanto, tomamos como referência os dados coletados em uma pesquisa integrada à Linha de Pesquisa Saúde e Reprodução Social Programa de Pós-Graduação em Sociologia — UFRGS, realizada juntamente com a Prof. Maria Assunta Campilongo. Neste caso, constituímos dois grupos de trabalhadores, um formado por mulheres afastadas do trabalho em atendimento no Ambulatório de Doenças do Trabalho do Hospital de Clínicas de Porto Alegre-RS e outro constituído por trabalhadores homens do Pólo Petroquímico de Triunfo-RS, também afastados do trabalho por adoecimento profissional, e que tinham vínculo com o sindicato da categoria. A temática dos grupos foi a análise de suas vivências na situação da afastamento do trabalho por adoecimento profissional.

Pretendemos, no decorrer desta exposição, demonstrar os elementos estruturantes destas vivências e, desta forma, evidenciar as relações entre saber-poder que perpassam, principalmente, a trajetória institucional-legal à qual são submetidos estes trabalhadores que, no confronto com o modelo produtivo, adoeceram.

Cabe, ainda, ressaltar, que as questões de gênero atravessam a vivência do afastamento do trabalho e implicam num diferencial importante entre os grupos, assim como implicam diferentes formas de vivenciar as experiências no cotidiano de trabalho.

Sobre saúde mental e trabalho — reflexões a partir do adoecimento e do afastamento do trabalho

A análise da Saúde e da Doença como dualidades possui uma historicidade associada ao "discurso médico" (Foucault, 1987). A concepção de doença, nele referenciada, possui três aspectos a serem ressaltados: a doença como ausência de saúde, a individualização na análise dos processos de adoecimento e a necessidade de classificação e diagnóstico das doenças que orientou o olhar médico para a doença e seu espaço de visibilização no doente e na sociedade. Tal fato possibilitou, como já referimos, a criação do espaço da clínica, no qual o saber médico (técnico, científico) exerce seu poder de falar sobre a morte e o adoecimento, legitimando-os.
Costa (1989) refere-se às limitações impostas pela concepção tradicional de saúde mental, ressaltando a matriz individualizante, a busca de uma essência da doença e a construção de um setting terapêutico clássico. Estes limites impostos pela concepção tradicional colocaram a necessidade de um redimensionamento da noção de construção psíquica e social das subjetividades individuais, através da análise da doença dos nervos (Costa, 1989). Isto porque, segundo o autor, não existe doença independente do seu modo de expressão. A representação da causalidade é indissociável da causalidade que a produz.

Suas reflexões, ao tomarem como eixo a discussão sobre a identidade psicológica e o sofrimento advindo da "quebra" do traço identificatório ser trabalhador, sugere que um importante aspecto associado ao sofrimento mental está na relação que a identidade mantém com a vida social.

O sofrimento advém da crise identificatória, pois, segundo Costa (1987), a ênfase no caráter normativo da identidade psicológica, implica em adotar certos padrões de sentimentos e comportamentos e excluir outros. Segundo o autor, a norma psicológica é mais coercitiva, pois é internalizada como universal, e essa qualidade é facilmente percebida, após ser internalizada, como sendo natural. A identidade social do sujeito, atrelada ao fato de ser trabalhador e associada a ideologia do trabalho livre, criou a ideia de trabalho como algo natural. A impossibilidade de relativizar esta norma é um núcleo importante do sofrimento mental.

Neste sentido, as representações construídas sobre saúde-doença e trabalho-não trabalho podem sustentar vivências de sofrimento.

O campo da psicopatologia do trabalho (Dejours, 1987) tem no sofrimento mental advindo das vivências subjetivas no cotidiano de trabalho, seu objeto de estudo. No entanto, não se trata de associar psicopatologia à doença ou à loucura, mas do estudo dos mecanismos e processos psíquicos mobilizados pelo sofrimento (Dejours e Abdoucheli, 1994).

$\mathrm{Na}$ tentativa de redimensionar a matriz individualizante que, como já vimos, marca a tradição da compreensão da saúde-doença, os autores sugerem evidenciar a ligação entre as pressões originadas da organização do trabalho e as defesas construídas coletivamente pelos trabalhadores frente a tais pressões, saber as estratégias defensivas coletivas (Dejours, 1994). Tais estratégias visam evitar o sofrimento advindo destas situações 
de pressão e não das situações de risco em si - é o que ocorre, por exemplo, entre os trabalhadores submetidos à atividades que envolvem riscos de acidente que, por vezes, desafiam o perigo, como forma de testar a dimensão do risco e os limites da sua segurança.

Ao descrever as estratégias de defesa coletiva que se desenvolvem como forma de proteção e ao mesmo tempo, como sintomatologia (esta relação é sempre ambígua) de situações de pressão no trabalho, pode-se compreender como, no momento do afastamento do trabalho, estas estratégias se rompem. $\mathrm{O}$ resultado disso é que estes trabalhadores passam a enfrentar de forma isolada e individual as consequências de um ambiente de risco do qual se defendiam e que passa a materializar-se na forma de doença e incapacidade. Neste aspecto está também uma importante fonte de sofrimento mental.

Assim, diferentes abordagens do sofrimento mental nos levam a pensá-lo sob dois aspectos diferentes de uma mesma questão: o sofrimento advindo da quebra do traço identificatório ser trabalhador, associado ao não cumprimento de normas pautadas em representações (Costa, 1989) e o sofrimento advindo das pressões da organização do trabalho (Dejours, 1994).

Estas duas dimensões estão expressas nas experiências dos trabalhadores afastados do trabalho por adoecimento profissional, pois, de um lado, encontra-se a quebra da identidade do ser trabalhador ocasionada pelo afastamento do trabalho e, de outro, a existência do adoecimento profissional expressa os limites das estratégias defensivas. Neste caso, o aparecimento do adoecimento profissional coloca a fragilidade destas estratégias à mercê de sua existência, o adoecimento é um fato concreto e deve-se às condições adversas e arriscadas das condições de trabalho, cujas consequências expressam-se no cotidiano destes trabalhadores.

\section{.1 Os impactos do adoecimento e do afastamento do trabalho no cotidiano}

A situação do afastamento do trabalho por adoecimento profissional remete os trabalhadores à esfera privada do cotidiano, sendo que esta passa a ter um lugar central nas suas vidas. O tensionamento das relações familiares, por vezes, é uma consequência desta predominância da esfera privada. Como referimos anteriormente, no momento em que se coloca a quebra do traço identificatório do trabalhador, pela presença do adoecimento e da incapacidade, também fica alterada a capacidade de cumprir com outras exigências sociais, como ser bom pai, marido, esposa ou mãe.

Para os homens, ficar em casa é passar a ocupar um lugar que não estava previsto na organização do lar. Ficou evidente um processo de isolamento tanto no interior da própria casa e da família, quanto das relações sociais e pessoais mais amplas. Enfim, uma vivência com aspectos que sugerem depressão, conforme pode-se perceber na fala de um trabalhador.

O cara fica com um sentimento de ficar inutilizado, impotente, assim para fazer as coisas. Pelo menos comigo. Também me colocaram na cabeça que eu precisava parar total. E eu que gostava de cuidar, consertar coisas em casa, deixar o jardim cheio de flores. E aí fica aquele clima, pois os vizinhos saem e tu ficas ali. E tu, aparentemente bem e os vizinhos todos saindo. Eu não transmiti meu problema para o pessoal, eles foram descobrindo depois. Eu não quis falar, mas ficava em casa. E eles, acho que pensavam: aquele foi para a rua! Não sei por que não disse nada, sei lá... senão, de repente, o cara não vai na tua casa, achando que vai se contaminar. Daqui a pouco os caras estão construindo um muro em volta da minha casa.

O trabalhador, neste caso, utiliza a metáfora do muro, evidenciando o isolamento a que se submetem e são submetidos em função do adoecimento e do afastamento do trabalho. Este isolamento pode remeter à uma situação de exclusão das relações sociais que evidenciam o espaço público e que estão referenciadas no trabalho.

Outra metáfora utilizada pelos trabalhadores é de que quando da situação de afastamento, a casa cai, ou seja, a casa cai quando o homem passa a ocupar um lugar indefinido para ele no ambiente familiar e no espaço doméstico.

Ficar em casa para quem é casado é tipo gato e rato. Começam as brigas e os desentendimentos com as mulheres e os filhos. A gente sente falta dos colegas.

Toda a organização da casa é pensada contando que o velho vai sair para trabalhar, e eles têm a vida deles, eu acho, dentro de casa.

Dividi os filhos na escola de manhã e à tarde. Às vezes eu me irrito e saio, mesmo tendo que ficar em casa. 
Com relação às mulheres, o retomo ao espaço exclusivamente doméstico implica em uma perda, pois o trabalho representa o acesso a um universo mais amplo que a casa e a família. Da mesma forma, há o reconhecimento do trabalho como algo produtivo, pois o trabalho doméstico não é valorizado como tal.

Trabalhando é bom. Em casa é sempre a mesma coisa: marido, filho, as mesmas caras a vida toda. Parecia a mesma rotina do serviço todo dia também. O serviço é todo dia a mesma coisa: lava roupa, lava louça, limpa a casa. No outro dia, tudo de novo. No serviço não, muda um pouco, porque conversa com pessoas diferentes, distrai. Em casa são sempre as mesmas pessoas.

Dejours (1987) refere que, enquanto para o homem a doença significa a paralisação do trabalho, para a mulher existe um agravante, pois para a mulher a doença não pode autorizar a paralisação do trabalho, pois o serviço doméstico e o cuidado dos filhos não cessa.

De certa forma, o espaço doméstico ou da casa passa a ser o espaço da doença e da improdutividade, enquanto o trabalho representa um local onde a saúde e a possibilidade de ser produtivo se realizam. Estas representações expressam o caráter dualista presente no discurso, que legitima a situação de isolamento.

O reconhecimento de sua situação de adoecimento como sendo profissional passa, então, a ser o que chamamos do difícil caminho percorrido por estes trabalhadores.

\section{2. $O$ (re)conhecimento do adoecimento profissional}

O adoecimento que tem sua origem vinculada ao trabalho possui características específicas, por ser o trabalho central na organização da sociedade. A partir do aparecimento do adoecimento e do dar-se conta desta situação, os trabalhadores empreendem o que chamam de uma via crucis pela burocracia do Estado brasileiro, tanto no que diz respeito à atenção e assistência à saúde, quanto no reconhecimento legal de seus direitos sociais. Estes aspectos sugerem o valor atribuído à força de trabalho e ao papel da medicina como ocupando um lugar justificador e legitimador na relação Capital-Trabalho.
O primeiro elemento que surge com relação ao adoecimento é o desconhecimento quanto aos riscos aos quais os trabalhadores estavam submetidos nos seus ambientes de trabalho.

Eu descobri que estava doente por mim mesma. Fui atrás dos exames, porque eu estava com dor de cabeça, diarreia pretinha, tontura e vômito e diziam que os níveis de mercúrio eram bons. Eles (os empresários) não falavam nada, só entre os colegas que a gente falava sobre os problemas do mercúrio.

Quando eu fui trabalhar lá, na limpeza, eu achava que o mercúrio era aquele vermelhinho...

Os trabalhadores do setor petroquímico chegam a referir-se sobre o Império do Silêncio.

Os problemas de saúde de uma empresa para outra e mesmo dentro da própria empresa, impera o império do silêncio quanto a qualquer problema de saúde e de segurança.

Todos os casos de doença são abafados e quando o cara é afastado por doença, ele não retoma à empresa e a desculpa para esconder o risco é o sigilo médico.

A estratégia do silêncio é uma forma de evitar a formação de processos coletivos que discutam o risco e pressionem para a alteração das condições de trabalho. Nestes casos, o papel dos médicos das empresas e da perícia médica da Previdência Social, muitas vezes, é entendido pelos trabalhadores como defesa do interesse do Capital.

Tem gente que estava a muito tempo com os exames alterados e o serviço médico escondia.

O INSS não trata, não examina e a consulta não dura quatro minutos. O perito nem levanta os olhos para ver o paciente.

Alguns trabalhadores referem que os médicos utilizavam ameaças explícitas de demissão caso fosse revelada a existência da doença e sua vincularão com o trabalho.

Estes trabalhadores expressam, também, que em várias situações são culpabilizados pelo adoecimento e este fato fica mais evidente na fala das mulheres, talvez porque os trabalhadores ligados ao sindicato tenham uma concepção mais definida sobre o papel do Estado nesta situação. 
A impressão que dá é que eles (os médicos) pagam, que tiram o dinheiro deles para dar para a gente. A impressão que eu tive foi que um animal me atendeu, porque aquilo não era gente.

Acho que os médicos, às vezes, eles pensam que a gente está doente para ficar, vamos supor, encostada no INPS. Ganhando e não trabalhando. Foi o que eu entendi quando fiz a perícia.

Este jogo no qual estão implicados o silêncio e a suspeição, constituem-se em elementos estruturantes de vivências de sofrimento e podem analisados sob o enfoque da "ideologia da vergonha" (Dejours, 1987). Esta traduz-se em um sentimento coletivo de vergonha que faz com que os trabalhadores evitem demonstrar seu adoecimento em razão de uma concepção dominante pautada pela acusação a quem está doente. O adoecimento é também tratado de forma individual e vivenciado como algo individual no momento em que a sua ligação com o processo e a organização do trabalho são ocultados ou negados. A consequência é que os trabalhadores sentem-se sós e responsáveis pelo próprio adoecimento.

Todo este processo coloca os trabalhadores em uma situação contraditória, pois devem apresentar-se fragilizados e incapacitados para que a existência do seu adoecimento não seja questionada. Assim, as formas utilizadas para evitar a fragilização e a incapacidade advindas da sua situação devem ser demonstrada ao inverso para os profissionais da área da saúde que lhes prestam assistência, principalmente. A possibilidade de seu acesso aos direitos sociais passa pela comprovação da sua incapacidade, fragilidade e improdutividade.

\section{Considerações Finais}

A análise das vivências dos trabalhadores afastados do trabalho por adoecimento profissional explicita os aspectos referentes à individualização da doença, o olhar centrado na doença e a oposição entre saúde e doença que tem como consequência a associação entre saúde e normalidade e doença e anormalidade.

O questionamento da veracidade da doença por parte dos profissionais da saúde sugere a representação de que quem adoece é vagabundo e não quer trabalhar, associando doença e não trabalho. A culpabilização do doente (individualização) e o descaso com as condições e organização do trabalho são fontes geradoras de vivências de sofrimento.

Estes fatores sugerem, entre tantos outros, a necessidade do redimensionamento destas concepções, principalmente ao considerar as vivências subjetivas e as representações construídas social, cultural e historicamente, a compreensão das situações de adoecimento não podem ocorrer exclusivamente pela análise de um diagnóstico clínico.

Este redimensionamento permitiria pensar com Canguilhem (1990) que, frente à situações de adoecimento, instauram-se novas formas de vida, em função de alterações físicas ou psicológicas que possa, dela, derivar-se. Na sua visão, saúde seria a possibilidade de ser normativo, ou seja, instaurar novas normas de vida que possibilitem lidar com a nova situação a partir do adoecimento. A existência do patológico não o coloca em oposição ao normal, mas como uma necessidade de redimensionamento desta normalidade. De certa forma, as reflexões sobre saúde mental e trabalho, que se originam do estudo dos trabalhadores afastados do trabalho por adoecimento profissional, sugerem a ampliação de nosso olhar sobre tal temática, enfocando o significado do trabalho e do ser trabalhador na sociedade e da associação entre adoecimento e vagabundagem que constroem representações sobre o adoecimento, principalmente, vinculado ao trabalho.

Estas reflexões indicam a necessidade de redimensionarmos, também, as políticas sociais no sentido de evitar uma nova forma de adoecimento profissional originada das vivências de sofrimento advindas da situação de afastamento do trabalho por adoecimento profissional.

\section{Referências bibliográficas}

CANGUILHEM, G. O Normal e o Patológico. Rio de Janeiro: Forense Universitária, 1990.

COSTA, J.F. Psicanálise e Contexto Cultural — imaginário psicanalítico. grupos e psicoterapia. Rio de Janeiro: Campus, 1989.

A Consciência da Doença Enquanto Consciência do Sintoma: a "doença dos nervos" e a identidade psicológica. Cadernos do Instituto de Medicina Social. n. 1, mar/abr. 1987: 5-43: Rio de Janeiro. 
DEJOURS,C. A Loucura do Trabalho. São Paulo: Cortez-Oboré, 1987.

. Trabalho e Saúde Mental: da pesquisa à ação. In.: DEJOURS, C. ABDOUCHELI, E. e JAYET, C. Psicodinâmica do Trabalho. São Paulo: Atlas, 1994.

DEJOURS,C. e ABOOUCHELI, E. Itinerário Teórico em Psicopatologia do Trabalho. In: DEJOURS, C. ABDOUCHELI, E. e JAYET, C. Psicodinâmica do Trabalho. São Paulo: Atlas, 1994.

FOUCAUlT, M. O Nascimento da Clínica. Rio de Janeiro: ForenseUniversitária, 1987.

SILVA, E. S. Saúde Mental e Trabalho. In.: TUNDIS, S. e COSTA, N.R. Cidadania e Loucura - políticas de saúde mental no Brasil. Petrópolis: Vozes, 1987.
Intervenção em um grupo de trabalhadores em processamento de dados

Assessoria em psicologia institucional e do trabalho Lucia Bertini e Guilene Salerno

Tradicionalmente, a intervenção da Psicologia nas organizações empresariais ocorre de duas formas: a primeira diz respeito aos clássicos recrutamento, treinamento, seleção, avaliação de desempenho, desligamento. Aproximando-se da prática da administração de empresas, embora muitas vezes contrapondo-se competitivamente a ela, esta é a forma mais frequente, ao avaliarmos o ingresso dos psicólogos nas empresas. Ainda, muitas vezes, este trabalho limita-se ao campo de recrutamento \& seleção, cabendo ao psicólogo somente a avaliação psicométrica e emocional dos candidatos a vagas nas organizações.

A outra forma de intervenção da Psicologia na área do trabalho diz respeito às consultorias em Recursos Humanos, geralmente para atuar no âmbito do desenvolvimento gerencial, quando aparece uma prática também assemelhada àquela do administrador, abarcando desta feita os níveis estratégicos e táticos da organização.

Uma breve revisão teórica permite visualizar a íntima relação das Teorias da Administração às tendências da Psicologia Organizacional, desde os conceitos fundamentais, passando pelos principais representantes, até semelhanças na concepção de homem.

De uma ou outra forma, atuando nos níveis estratégico, tático ou operacional, fica claro que o psicólogo vem a engrossar as fileiras da equipe administrativa encarregada da execução das políticas da empresa, desde a concretude das tarefas cotidianas do trabalhador da base da pirâmide hierárquica até a realização mais estratégica, de planejamento e gestão da organização. $\mathrm{O}$ que, em última análise, termina por levar-nos à Teoria Clássica da Administração, à Taylor e à revolução industrial, que precisou arregimentar tal equipe para a implantação dos métodos e processos de racionalização do trabalho, para obter, enfim, o maior rendimento e o menor custo do trabalho.

${ }^{1}$ Trabalho apresentado no V Encontro Regional da ABRAPSO.

${ }^{2}$ Psicólogas e consultoras em RH. 
A primeira forma, de abordagem geralmente individual, de medição, toma o trabalhador desde sua singularidade. Conforme Guareschi e Grisci (1993), a norma é falar e tratar com um trabalhador de cada vez, o que possibilita mais facilmente o convencimento e a exploração.

Por outro lado, no entanto, as técnicas grupais são atualmente utilizadas em larga escala dentro das organizações, com os mesmos objetivos de controle e de domesticação do trabalhador. Castel e Lowell, (Apud, Baremblitt, 1986), em uma crítica ao grupalismo e ao seu uso, destacam que uma das características da dinâmica grupal é a de transformar os conflitos resultantes do sistema de exploração e dominação capitalista em problemas de normalidade-anormalidade ou saúde-patologia. Dispensando o uso da força do controle social, criar-se-ia um dispositivo médico-psicológico de vigilância e manutenção da ordem, de acordo com os métodos permitidos socialmente pela livre-iniciativa. É comum o comentário do trabalhador organizado em suas entidades ou em comissões de fábrica a respeito dos trabalhinhos de grupo propostos na empresa pelos psicólogos, que estariam distraindo-os das questões mais fundamentais em suas lutas por melhores salários e condições de trabalho.

Frente a esta realidade de sustentação à exploração do trabalhador, ao reconhecer-se como psicólogo a serviço dos mesmos interesses capitalistas a que serviram Taylor, Mayo, Weber, McGregorg, Katz e Kahn e tantos outros, além de uma gama de profissionais desenvolvidos para este fim, seria possível uma intervenção que desviasse deste destino? É possível colocar-se ao lado do trabalhador, em uma atividade a serviço da organização? Pode-se subverter a ordem e escapar à determinação da neutralidade, que é engajada à organização, permanecendo nela?

Ao propor este trabalho na empresa, tentou-se responder a estas questões, refletindo sobre o assunto. Ao relatá-lo, pretende-se avançar no questionamento. E observa-se, no mínimo que existem questões do trabalho para uma abordagem diferenciada assim como campo e confiança dos trabalhadores para uma tentativa de revisão da prática sustentados por grande parte da categoria dos psicólogos até então.

Este relato é oriundo de uma consultoria a uma empresa de Processamento de Dados, em que todos os empregados deveriam ser trabalhados, conforme a contratação, e as psicólogas inicialmente propuseram a realização de um breve levantamento de necessidades, inicialmente.

Cabe esclarecer que num primeiro momento o trabalho foi realizado por duas profissionais que não conheciam-se mutuamente, contratadas separadamente. Com o andamento do processo, somente uma profissional permaneceu na empresa, no caso a que encaminhou a proposta, sendo o trabalho desenvolvido com esta profissional atuando em campo e outra também trabalhando na análise dos dados, no caso, as autoras do presente artigo.

Os trabalhadores, o sindicato da categoria e seus representantes levantaram dúvidas sobre este trabalho e seus objetivos, tendo sido discutido o assunto em reunião que contou com a presença dos mesmos, da representação da empresa e da assessoria.

Posteriormente, a assessoria circulou por todos os setores apresentando o resultado daquele levantamento realizado e a proposta das Oficinas de Trabalho, metodologia estruturada com base em uma experiência vinculada aos órgãos de saúde pública para trabalhar a saúde da mulher, e utilizada, também, para pesquisar a saúde no trabalho, em uma empresa pública de Processamento de Dados.

Ao refletir sobre a intervenção da Psicologia no meio empresarial, salientou-se anteriormente o vínculo do psicólogo com a empresa e a distância estabelecida com o trabalhador. O psicólogo representa o patrão, a empresa e seus interesses, e este lugar já permite que pensemos na dificuldade da aproximação espontânea ou voluntária citada. Ainda mais se lembrarmos que muitas vezes o trabalhador é encaminhado ao gabinete de psicologia pela chefia, frente a problemas surgidos no trabalho, e fica ao encargo do profissional encaminhar clinicamente o corretivo, isentando a chefia de exercer seu poder diretamente.

Da mesma forma, quando a empresa contrata um trabalho de assessoria externa, como foi o caso, mesmo a adesão voluntária pode ser questionada. Muitos dos nossos trabalhadores chamados aos grupos compareceram como parte de suas obrigações, mostrando-se desdenhosos, indiferentes ou contrariados. Outros, procurando a assessoria individualmente, partilhavam suas preocupações com relação aos próprios problemas, à questão do trabalho (do setor ou da empresa) e quanto aos 
rumos da empresa, já que a mesma encontrava-se em fase de definições técnico-políticas.

Assim, como parte da metodologia, inseriu-se a possibilidade de utilizar quantos encontros fossem necessários para dar conta da compreensão da proposta e da formulação de uma demanda coletiva. Desde o exame das expectativas até o esclarecimento das etapas de trabalho e a transformação ou adaptação da proposta às necessidades de cada grupo específico, estabeleceram-se gradativamente compromissos dos grupos na análise de seu processo de trabalho, mobilizando-os racionalmente e afetivamente na construção desta análise.

A ampla divulgação e o caráter de adesão voluntária aos trabalhos demonstraram efeitos importantes de crédito às Oficinas, que contaram com um percentual de participação de $84,4 \%$ dos trabalhadores da empresa.

Embora a proposta não fosse a de realização de uma pesquisa em psicopatologia do trabalho, a metodologia utilizada pode ser fundamentada por Dejours (1994), quando aborda o processo de formação da demanda. Este aponta a necessidade da transformação da demanda inicial, que se articula no colóquio individual, na demanda coletiva, social, obtida através do debate, da informação e do avanço pelos sujeitos em sua interpretação da organização do trabalho. $\mathrm{O}$ autor cita a passagem da demanda de cuidados à demanda de sentido, num processo longo que passa pela construção de uma formulação comum, em que ao seu final apresentam-se os voluntários, dispostos a participar e a garantir a autenticidade do trabalho.

Assim, os encontros foram marcados como um espaço de discussão e construção do processo participativo, que se dá, se constrói num grupo através do próprio reconhecimento e de sua história.

\section{A proposta tinha como objetivos}

- Criar a identidade do grupo através da construção de um personagem coletivo;

- Propiciar a reflexão sobre as próprias vidas, o trabalho e suas repercussões;

- Discutir a organização do trabalho, analisando as atividades realizadas, levantando formas e alternativas para novas ações;
- Propiciar a reflexão do grupo sobre as relações de trabalho, processo de comunicação, a realidade, o contexto em que está inserida a empresa, possibilitando a alternativa de mudança;

- Desenvolver a capacidade de consciência e ação do grupo na mudança de sua organização no trabalho.

Tendo em vista o caráter flexível deste trabalho, na medida que as discussões aconteciam, em função do seu próprio ritmo e necessidades, cada grupo realizou de 08 a 20 encontros aproximadamente. Da mesma forma, o início dos trabalhos com cada grupo ficou vinculado a sua própria adesão à proposta. Eram realizados encontros semanais, com duração aproximada de 2 horas.

Utilizou-se sempre técnicas participativas. Depois das discussões, cada grupo deveria criar um personagem coletivo que o representasse, passando posteriormente à análise do processo de trabalho e ao planejamento de sua organização.

O personagem coletivo é uma forma de construir em grupo a caracterização de um sujeito representativo das pessoas presentes, envolvendo um roteiro de dados de identificação como idade, aparência, sexo, estado civil, profissão, medos, desejos e projetos, vida social, saúde no trabalho, família, entre outros, que aos poucos permite que o grupo elenque aquelas características mais marcantes e comuns ao conjunto de participantes, possibilitando a revelação e a reflexão sobre sua identidade. Após a criação verbal, o personagem deve concretizar-se no papel através de desenhos e colagens selecionados pelo grupo, que visualizará e discutirá a fotografia criada.

O grupo escolhido para análise, equipe de Analistas de Suporte em Informática, desde o momento inicial mostrou-se crítico. Apesar de participar da análise do levantamento de necessidades e da discussão da proposta apresentada pela assessoria, não aderiu imediatamente ao processo, mas manteve-se atento ao trabalho desenvolvido com os outros grupos.

Fisicamente, a sala do Suporte situava-se muito próxima da sala de treinamento, local onde eram realizados os encontros, o que possibilitava um contato mais informal com a assessoria e com o processo de trabalho desenvolvido. À medida que o tempo avançava, um vínculo maior 
estabeleceu-se com os trabalhadores da empresa, participantes ou não do Trabalho de Oficinas.

No intervalo entre um grupo e outro, a assessoria circulava pela empresa, mantendo desta forma um contato contínuo com os trabalhadores lotados na Produção e no Suporte. A sala do cafezinho, por longo período, situou-se na sala destes últimos, sendo este um local de acesso e procura constante de muitos funcionários. Nestes momentos informais, estabeleciam-se discussões sobre a instituição, processos de trabalho e funcionamento do grupo de Analistas de Suporte, que muitas vezes procuravam pela assessoria para que opinasse sobre determinado assunto em discussão.

Esta relação propiciou que o grupo fizesse sua adesão ao trabalho de Oficinas. A partir da queixa de falta de chefia e de sua desorganização, o grupo vislumbrou a possibilidade de, através da proposta discutida, repensar sua organização de trabalho e de grupo.

Cabe ressaltar que, apesar do momento de adesão ter sido voluntário e autônomo, o grupo apresentou-se reticente à técnica proposta, com atrasos de horários e ausência de alguns participantes.

Foram realizados um total de 14 encontros. O grupo iniciou com a montagem do personagem coletivo. Enquanto manteve-se na construção verbal, a fluência e participação foram contínuas. Assim que foi proposta a construção concreta do personagem, o grupo recuou, dizendo que não poderiam construir um personagem porque no momento era mais importante pensar sobre a chefia que não possuíam, porque a representação do personagem no papel poderia permitir que questões de ordem subjetiva emergissem, tinham receio de utilizar uma ferramenta (técnica proposta pela assessoria) que não dominavam, e, afinal, nem entendiam por que motivo deveriam seguir a proposta, se a discussão que estava sendo realizada mostrava-se produtiva.

Mesmo com estas reflexões o grupo brincava com o processo de construir o personagem, fazendo caricaturas e bonecos estereotipados, e assim seguia discutindo sua criação verbal, concluindo que alguns aspectos não eram verdadeiros, mas idealizados, outros haviam sido omitidos. Com um personagem mais real, evoluíram para a discussão do perfil de chefia, esta ainda também ideal, que revela a necessidade de limites do grupo, associando desorganização e serviço público.

A coordenação retoma a proposição inicial, da construção do personagem coletivo. Aparece a discussão: Que personagem - que grupo temos? A saída proposta é a criação de vários personagens, cada um o seu, aparecendo a discussão coletivo $x$ individual, sua dificuldade de organização, a falta de compromissos coletivos. Os trabalhos individuais apresentados foram complementares: um retratou cenas do cotidiano do trabalho, outro resgatou a história do trabalho e suas contradições, ainda um terceiro, caricaturizando, mostrou o poder exercido pelo grupo, desenhando um osso (duro de roer) com pênis, viril.

Finalmente, este processo intermediário possibilitou a construção de um personagem único, demonstrando características em cujas representações os participantes se reconheceram, mostrando-se surpresos com o fato de terem conseguido abrir mão de suas posições, na construção de algo em comum que veio a envolver todo o grupo. Associam, aos poucos, este funcionamento com a organização de seu trabalho: trabalho individualizado, sob pressão, necessitam conhecer o trabalho dos outros e não repassam seu conhecimento.

Sabe-se que o processo de produção caracteriza-se pelo controle do capital sobre o trabalho e que a cada momento histórico diferentes necessidades de organização são estabelecidas, a partir de formas específicas de divisão técnica e social do trabalho.

A organização do trabalho informático, desde seu surgimento, já caracterizava duas funções nitidamente distintas: a do analista, que pesquisava e criava os programas de acesso à máquina e a sua operação, e a do perfurador de dados (hoje digitador), que perfurava os cartões de entrada de dados (Soares, 1989).

As novas tecnologias exigem um trabalhador diferenciado. Nos setores em que predomina o saber técnico e a qualificação, como é o caso dos Analistas de Suporte, o trabalho é determinado pela demanda, há autonomia e autodisciplina, caracterizando-se a organização flexível, por um lado, e a desqualificação das outras áreas, que dependem do Suporte. 
O que se verifica é que a extrema qualificação distancia este grupo hiperqualificado do conjunto da população da empresa, que ti solicita desde seu saber absoluto. Por outro lado, a própria construção coletiva deste grupo ficava prejudicada, uma vez que o saber os colocava cada um isolado, dando conta de seu próprio trabalho, fazendo desta forma de funcionar um círculo vicioso, inviabilizando um trabalho preventivo em que pudessem socializar o conhecimento.

Nossa hipótese é de que a construção coletiva do personagem possibilitou reconhecer de que forma a organização do trabalho influencia os sujeitos deste grupo, retirando dos mesmos a responsabilidade pessoal de seu jeito de ser, comumente atribuída ao sujeito, desatrelada da organização do trabalho.

A vantagem é de que, conscientes da relação estabelecida com o trabalho, podem os sujeitos melhor propor e conduzir a mudança em sua organização.

Novamente aqui evoca-se Dejours (1994), que diz que a ação de transformar deve passar pelos próprios atores. Não se trata de alcançar a organização ideal do trabalho, mas, como o autor afirma, de "estimular a dinâmica intersubjetiva de transformação da organização do trabalho" (p. 86).

Assim, nossos atores do suporte, passam a rever toda sua atividade, discutindo-a pormenorizadamente e planejando o trabalho do setor. Aos poucos, refletem sobre a necessidade de partilhar o saber, ensinando, e ensaiam uma aproximação de um outro grupo/setor que no processo de trabalho lhes é muito vinculado, complementando-se. Conseguem rever questões da organização do trabalho que até então estavam somente contempladas no discurso, em um espaço desorganizado. Já haviam pensado, mas não sistematizavam.

O grupo reconheceu-se enquanto tal, definindo sua identidade profissional, e organizou-se de forma a dar a conhecer uns aos outros o trabalho de cada um, estabelecendo o fluxo do trabalho, as relações e a organização do trabalho. O grupo apropriou-se de seu trabalho e passou a dar importância ao subjetivo nas relações como fundamental para sua realização, muito além do nível técnico e individual operado até então, extrapolando sua ação até o coletivo da empresa e contribuindo para a reflexão e tomada de posição coletiva dos demais setores.
Por fim, retomando a ação da assessoria, poder-se-ia dizer que a mesma tratou de possibilitar que a relação informal se instalasse, tentando o tal desvio levantado no início deste artigo (seria possível uma intervenção que desviasse deste destino? É possível colocar-se ao lado do trabalhador, em um atividade à serviço da organização?), talvez alcançando um posicionamento menos neutro, menos formal, mas não menos ético na profissão. Pode-se afirmar que a criação de um espaço formal que respeitou o tempo de cada grupo, possibilitou que o grupo informal se organizasse, sem abandonar as riquezas de sua espontaneidade e os aspectos subjetivos, afetivos e criativos em prol de uma melhoria em sua organização do trabalho.

Uma última etapa prevista, de realização da Plenária final de objetivação e encaminhamento dos diversos setores não aconteceu. Mudanças políticas encaminhadas no curso da empresa suspenderam o trabalho. Mas a descontinuidade formal e planejada não interrompeu o exercício de confrontar diferenças e divergências enquanto sujeitos autores no trabalho que se estabeleceu e se autogere a partir da apropriação de suas histórias e vidas no trabalho.

\section{Referências bibliográficas}

BAREMBLITT, G. Grupos: Teoria e Técnica. Rio de Janeiro, ed. Graal, 1986.

CHANLAT, J. S. O Indivíduo na Organização: Dimensões Esquecidas, v. 1, ed. Atlas, São Paulo, 1993.

DESJOURS, C. et alii. Psicodinâmica do Trabalho. Contribuições da Escola Djouriana a Análise da Relação Prazer, Sofrimento e Trabalho, ed. Atlas S.A., São Paulo, 1994.

GUARESCHI, P. A, e GRISCI, C.L.I. A Fala do Trabalhador, ed. Vozes, Rio de Janeiro, 1993.

SOARES, A.S. A Organização do Trabalho Informático. Dissertação de Mestrado em Administração de Empresas, PUC, São Paulo, 1989. 


\section{Zero hora prega o extermínio de espécies - a ideologia nos meios de comunicação de massa.}

Marcos de Oliveira Muller ${ }^{l}$

Introdução:

Comecemos dum modo amplo!

As relações sociais da atualidade estão marcadas, cada vez mais, pelo fenômeno da comunicação de massa. Trata-se dum arsenal poderosíssimo que atinge, de diferentes modos, com mecanismos seletivos e com propósitos diversos, o quotidiano dum sem número de pessoas e que tem, evidentemente, um papel importantíssimo na diligência da vida social. Através da produção, transmissão e recepção de formas simbólicas, num enorme potencial massificador, proporciona-se uma série de informações que entram, inclusive, na formação, construção, manutenção e transformação da identidade, o que nos remete à questão da consciência e do agir humanos. Somos, em muito, função dos meios de comunicação de massa que nos atingem quotidianamente.

Tal arsenal, como bem o sabemos, ocupa um lugar privilegiado em nossa sociedade - o que equivale dizer: no sistema capitalista - vendendo - desde produtos materiais até estilos de vida. Dito doutro modo, os meios de comunicação de massa, em grande medida, sustentam e são sustentados pelo sistema capitalista. Aqui, insere-se um elo bastante forte, um sustentar primordial: o estabelecimento e sustentação de relações de poder e dominação. Entra em cena, então, dum modo inexorável, a inter-relação entre comunicação de massa e ideologia. Frisemos uma fundamental contextualização a fim de que não se corra o risco de cair no que Thompson (1) chama de falácia do internalismo, onde haveria um caráter ideológico em si e independente: trata-se duma contextualização sócio-histórica, que envolve a produção/transmissão, construção e recepção/apropriação de formas simbólicas (1). Assim, estamos interessados, neste estudo, em analisar e interpretar formas simbólicas que cumprem um papel ideológico significativo.

${ }^{1}$ CPG em Psicologia Social e da Personalidade / PUCRS — Porto Alegre - RS. Grupo de Pesquisa em Ideologia, Comunicação e Representações Sociais.
Para tanto, escolhemos alguns textos, escritos por diferentes autores, publicados numa seção nobre (a seção "cultural" de domingo) dum grande — quase oligopólico — jornal, durante uma sequência de domingos. Foram publicados na forma duma série intitulada Espécies em Extinção (que inclui outras "espécies" e que, quando da elaboração deste trabalho, ainda estava em andamento - conforme notas 1 e 2, no fim deste capítulo).

Utilizamos o referencial metodológico da Hermenêutica de Profundidade (HP) de John Thompson (1), que se constitui, basicamente, de três fases: 1) Análise sócio-histórica; 2) Análise formal/discursiva; 3) Interpretação/reinterpretação. Tal referencial é utilizado para compreender e interpretar formas simbólicas; no caso da interpretação da ideologia, há uma inflexão crítica sobre essas fases, usando-as com a finalidade de identificar o significado a serviço do poder (1).

\section{Situando a análise:}

Conforme a inflexão crítica mencionada anteriormente, a análise sócio-histórica se orienta, então, para o estudo das relações de dominação, e a análise formal / discursiva, para a identificação das “(...) características estruturais das formas simbólicas que facilitam a mobilização do significado.” (1, p.292). Thompson propõe, a partir daí, a fim de desenvolver a conexão entre tais características estruturais e a interpretação da ideologia, o seguinte quadro dos modos e estratégias de operação da ideologia (pp.60 e 292-3):

\section{Modos de operação da ideologia}

\begin{tabular}{l|l}
\multicolumn{1}{c|}{ Modos gerais } & \multicolumn{1}{|c}{$\begin{array}{c}\text { Algumas estratégias típicas de } \\
\text { construção simbólica }\end{array}$} \\
\hline Legitimação & $\begin{array}{l}\text { Racionalização: Universalização, } \\
\text { Narrativação }\end{array}$ \\
\hline Dissimulação & $\begin{array}{l}\text { Deslocamento: Eufemização, Tropos } \\
\text { (sinédoque, metonímia, metáfora) }\end{array}$ \\
\hline Unificação & $\begin{array}{l}\text { Estandartização: Simbolização da } \\
\text { unidade }\end{array}$ \\
\hline Fragmentação & Diferenciação, Expurgo do outro \\
\hline Reificação & $\begin{array}{l}\text { Naturalização: Eternalização, } \\
\text { Nominalização/passivização }\end{array}$
\end{tabular}


Entretanto, o autor não os coloca duma forma exclusiva e fechada, mas deixa em aberto a possibilidade de operação doutros modos e estratégias. Além disso, entendemos que tais modos e estratégias não operam isoladamente, mas singularmente combinados.

\section{Análise crítica}

Seguiremos, agora, com uma breve análise argumentativa e interpretativa (esperamos que sirva de incentivo para que o leitor possa vislumbrar outras nuanças - algumas, talvez, saltem aos olhos - que mereçam, a título de análise, ser apontadas) específica para cada uma das espécies em extinção da sequência selecionada, que são as seguintes, em ordem cronológica crescente: Yuppies (4), O Noivo (5), O Jovem Comunista (6), O Bicho-Grilo (7), O Jornalista Boêmio (8). (Fazendo parte das respectivas matérias, foi publicada uma foto ilustrativa para cada uma delas, as quais - além, evidentemente, da diagramação resolvemos suprimir.)

\section{Yuppies: Profetas da religião que reverenciava o dólar.}

A juventude foi new wave, rockabillie, heavy metal, skinhead, dark, punk, new age e yuppie na década de 80. Alguns tipos permanecem agarrados nas boias da modernidade, com o pescoço já molhado. Outros naufragaram definitivamente com o peso de uma época narcisista devoradora e desiludida. Era de uma gente atrapalhada, de uma tevê apatetada, de um cinema estéril, de uma música repetitiva e de uma ceifadeira chamada AIDS, que amaldiçoou até mesmo alguns que não transaram. Pelo menos uma destas espécies, especialíssima, está condenada à rápida extinção. Os yuppies - sigla que define o young upwardly mobile urban professional, o jovem profissional urbano em ascensão - estão com os dias contados.

Predadores da Era Reagan, prosperaram pela absoluta ausência dos seus inimigos naturais: a honestidade, a decência e a consciência. Foram arautos e profetas de uma religião que rezava em dólares. Bilhões deles.

Seu verbo preferido era ostentar. Um chip cerebral conectado com cartões de crédito era uma espécie de Deus de plástico. "Quem tudo quer, tudo pode". Lema, frase de um hino quase religioso do dourado catecismo yuppie. Tiveram seus dedos decepados pelo crack da Bola de Nova Iorque em 1987. Foram-se os anéis. Ficaram os Rolex, símbolo de um tempo que parou no tempo, e os ternos Armani, mas sem os charutos Hoyo Monterrey, de 140 dólares, que recheavam um bolso inteiro, à esquerda da agenda eletrônica Cartier - embora os preciosos números telefônicos não servissem mais para nada. Os celulares emudeceram.

Foram-se as Ferraris Testarosa, os Volvos e as BMWs, as ilhas privadas, águas azuis, plenas de sol, o Concorde, o flat em Londres. Arrogância, definitivamente, nunca pagou imposto. Mas os yuppies pagaram muito caro por ela. E, ao contrário da ararinha-azul, ninguém vai chorar quando o último deles tiver desaparecido.

Em primeiro lugar, atentemos para o fato de que as características e adjetivos apontados à década passada podem ser facilmente aplicados à presente década. Especialmente a injustiça social está aí, cada vez mais, para provar isso. Portanto, de forma alguma são fatos duma época passada, mas estão bastante presentes, fazendo parte duma estrutura que engloba e ultrapassa o mundinho dos yuppies de Nova Iorque. A busca dessa ascensão social, desse enriquecimento, é um fluxo burguês, um caminho talvez hoje mais difícil de ser trilhado, e, se os yuppies entraram num processo de extinção, não foi porque eram maus e abomináveis, mas, talvez, porque a estratificação social tenha aumentado. A arrogância talvez tenha residido justamente aí, na falta de consciência de que, dos berços de que vieram, não poderiam seguir tão facilmente na obtenção de conquistas que os de fato berços de ouro desde sempre, por meio da herança, tiveram garantidas. $\mathrm{Ou}$ seja, os yuppies tiveram o gosto, inédito para eles, da riqueza exuberante, e lambuzaram-se muito, irremediavelmente. Todavia, os sempre ricos e poderosos, os donos do jogo, continuam lá, e a mesma mão que, por conveniência, alimentou os ditos yuppies, acabou empurrando-os de sua reles e frágil escada e observou, de camarote, sua queda. O lema "Quem tudo quer, tudo pode" foi, com isso, um equívoco da mesma falta de consciência, uma distorção de que nem tudo é para quem quer, mas para quem pode, ou, expressando o liberalismo ainda muito em voga: Quem pode mais, chora menos, mas acabaram com o Querer não é poder. Se os yuppies estão em extinção, os bens representantes da vida que sempre almejaram não o estão, como bem demonstra os itens ao final do texto, dando os créditos dos objetos que aparecem na foto ilustrativa dum yuppie (com os telefones, inclusive, donde adquiri-los). 


\section{O Noivo}

O Noivo foi na Antiguidade o sujeito que, em vez de raptar a namorada, preferia pedir aos pais da moça a mão da pretendida. Com o Noivo, portanto, o homem das cavernas ganhou um neto ajuizado, movido por boas intenções e dotado de um verniz de civilização a recobrir-lhes as disposições bárbaras. A evolução dos tempos fez do Noivo aquele sujeito que, acossado pela absoluta impossibilidade de extrair da namorada mais que assustados abraços no som da sala, sob a zelosa supervisão da futura sogra, sucumbia ao ritual do noivado para avançar alguns milímetros em seus objetivos expansionistas. $\mathrm{O}$ anel da mão direita tinha um nome - Romeu e Julieta - e se compunha de uma pérola e um brilhante, sempre juntinhos. Era o instrumento para a anexação de duas colinas, ou para incursões no mais cobiçado dos vales.

Noivar, explicam os dicionários, sempre quis dizer "contratar casamento" - e muitos povos codificaram pesadas punições para quem se atrevesse a romper tal compromisso sem justificativas convincentes. No Brasil, historicamente, os dois tipos de Noivos - o bom e o mau, ambos em acelerado processo de extinção raramente optam por rupturas. O Noivo bom mantém o compromisso porque efetivamente deseja casar-se, e só descumpre a promessa quando se apaixona por outra (com quem logo trata de noivar). Noivo mau (também chamado de Noivo eterno) é o que nunca pensou em casamento. Só pensa naquilo, compulsão que acaba por transformá-lo num profissional do sofá.

Um Noivo dos bons tempos exigia a movimentação de um elenco mínimo de coadjuvantes (além da moça) num cenário minuciosamente construído. O pai severo e a mãe alternadamente desconfiada e confiante ocupavam a sala maior. Uma porta entreaberta dava para a sala equipada com um único som - o som do Noivo. A irmã mais nova se encarregava de transmitir à moça sinais de perigo. Hoje, não é preciso noivar para fazer muito mais do que faz um Noivo ortodoxo. Melhor que usar anel na mão direita é usar camisinha.

Traz-se, agora, a tônica das extinções para a dinâmica familiar. Façamos - como podemos fazer para todas as outras espécies em extinção - a seguinte pergunta: Será que, realmente, o noivo está em extinção? Podemos admitir que as normas morais rígidas das relações homem-mulher e familiares afrouxaram-se um pouco das últimas décadas até hoje, e, com isso, os modos de transcorrer um noivado também mudaram. Entretanto, a sociedade continua fundamentalmente patriarcal e machista. Assim, para o noivo conseguir o que realmente quer, como o texto subentende, seus objetivos expansionistas, ele não precisa mais usar anel na mão direita, mas sim, camisinha, aludindo-se, aqui, à AIDS. E o papel da mulher, nesse contexto, onde fica? Será ela apenas algo a ser conquistado, como antigamente, mudando apenas o fato de que agora a facilidade aumentou e de que a camisinha se faz necessária?

\section{O jovem comunista:}

Ainda existem garotões que acham possível misturar rebeldia com stalinismo, mas seus dias estão contados.

O jovem comunista é um triste anacronismo. Como um comunismo pode ser jovem? Como um jovem ainda pode ser comunista? É justamente pela incongruência, pela impossibilidade de associação entre o que é novo (ou deveria ser) com o que é definitivamente velho, gasto e ultrapassado, que o jovem comunista é uma espécie em acelerado processo de extinção. Ainda restam alguns zurrando por aí, é claro, pensando em alçar-se a cargos públicos, discursando de dedo em riste e - surpresa das surpresas - posando de rebeldes. Rebeldia e stalinismo de fato é uma mistura mais implausível do que Rambo e Gandhi, presuntada e arroz integral, Ruanda e Suécia. O jovem comunista finge que não sabe disso.

Durante o longo (e merecidíssimo) processo de execração do expresidente Fernando Collor, garotões de todo o Brasil pintaram as caras e saíram às ruas para exigir a derrubada do facínora. Concederam um outro - e muito mais louvável — sentido à palavra colorir. Só que, de repente, alguém decidiu decretar que o líder deles era um certo Lindbergh Farias Filho. Jeitão de bom moço, sorriso aparentemente franco, bonito, o menino virou muso do impeachment e muita gente foi atrás. Collor caiu (não tão fundo quanto gostaríamos), mas o tempo mostrou que, de certa forma, Lindbergh não era muito melhor do que ele.

Lindbergh, afinal, revelou-se a mais perfeita encarnação da contradição ambulante que é o "jovem comunista”. Ele venera João Amazonas - um "velho comunista" (espécie quase tão extinta quanto o pássaro Dodô das Ilhas Maurício). Ele é a favor da 
estatização como cura para todos os males. Ele acha que $O$ Capital serve para alguma outra coisa que não seja permanência na estante. Julga Fidel Castro um cara legal e, de vez em quando, escuta Prá Não Dizer que Não Falei de Flores, de Geraldo Vandré. Um caso grave, portanto.

É melhor desconfiar de quem tem 18 anos e não possui ideais mais ou menos socialistas, sonhos utópicos e vertigens ecumênicas. Mas entre possuí-los e tornar-se um "jovem comunista" não existe apenas uma grande diferença: existe uma contradição inteiramente insuplantável.

Esse texto traz, como exemplo ideal da espécie em questão, uma pessoa específica (o então presidente da União Nacional dos Estudantes UNE), que aparece, na foto ilustrativa, num comício, com a legenda: "No púlpito: Lindbergh Farias Filho, o muso do impeachment, posando de rebelde numa manifestação em Porto Alegre, em 1992”. O ponto central é o comunismo, o socialismo, as estatizações, o papel político da juventude... São colocados como "anacronismos", "sonhos utópicos", incongruentes e associados à imaturidade. A direcionalização do texto é grosseira, ofensiva e ridicularizadora, com os tons jocosos da série intensificados. Na visão do texto, o jovem pode — o que até é "normal" — possuir, por imaturidade, "ideais mais ou menos socialistas, sonhos utópicos e vertigens ecumênicas", mas não exercê-los, pois isso o remete a uma "contradição insuplantável", colocando-o nesse rol de figuras altamente execráveis. Aqui, o jornal exerce seu poder sobre uma pessoa específica, que, obviamente, generaliza-se; com isso, atinge, ao mesmo tempo, tanto a pessoa referida quanto o grupo em que é colocado como representante (os "jovens comunistas"). Poder-seia concluir, com isso, que o jornal em pauta defende, pela ridicularização de tal exercício político e de pontos de vista que não sejam compatíveis com os seus, o sistema político e social do capitalismo (por exemplo, quando esse texto diz que a "espécie" em questão "é a favor da estatização como cura para todos os males").

\section{4 "O bicho-grilo}

O "ripongus doidus", um remanescente de outras e malucas eras, luta para não desaparecer da face da terra.

O bicho-grilo (ripongus doidus) é indubitavelmente uma espécie em extinção, embora já tenha praticamente nascido assim. De qualquer forma, os estudiosos ainda não chegaram sequer a uma conclusão sobre a correta notação científica: bicho-grilo, com hífen, ou bicho grilo, sem hífen? Fiquemos com bicho-grilo com hífen, por enquanto.

A pelagem do bicho-grilo é inconfundível. As manchas, harmonicamente distribuídas, simulam rostos de Che Guevara, Janis Joplin, Jimi Hendrix, símbolos do PV ou capas de discos de bandas como Led Zeppelin. Os habitats naturais do bicho-grilo são as feiras de artesanato, o Brique da Redenção, grêmios estudantis, shows de música folclórica latino-americana e quitinetes de fundos, penumbrosas, decoradas com pôsteres de Charles Chaplin e uma samambaia - que é a mais perfeita representação do que se pode chamar de natureza morta. Nesses cubículos, o ar apresenta a densidade ideal de incenso necessária à sobrevivência do bicho-grilo. Em Porto Alegre, a maior colônia de bichos-grilos, naturalmente está na rua Silva Sóóóó. O burro zurra, o gato mia, o cachorro late, a galinha cacareja. E o bicho-grilo balbucia. Alguns de seus sons já foram traduzidos. Exemplos: bicho (pessoa), baia (casa), careta (cigarro), picho (dinheiro). O bicho-grilo tem hábitos higiênicos, digamos, peculiares - levemos em conta o relativismo cultural como demonstra a característica oleosidade das longas cabeleiras.

As causas da extinção do bicho-grilo ainda não foram determinadas. Alguns cientistas atribuem-na à falta de novas músicas de Raul Seixas; outros, à baixa taxa proteica de sua dieta, exclusivamente à base de pão de queijo. Na época da reprodução, os bichos-grilos repetem um ritual milenar de acasalamento. Refugiam-se em acampamentos na Serra Gaúcha, sob alimentação especial macarrão com sardinha - e fumam longos e grossos cigarros de uma erva mística, que chama de coisa. Os resultados são filhos com nomes de Cachoeira, Pedra, Melado, Capim, por aí.

Mesmo à beira da extinção, os bichos-grilos apresentam capacidade de regeneração impressionante. Sobrevivem, como as lagartixas e as estrelas-do-mar, até à extirpação de membros importantes, como Jim Morrison e, recentemente, Kurt Cobain. E, ao contrário dos golfinhos, das baleais e dos lemingues, não costumam cometer suicídio coletivo.

Embora torcida não falte para isso.

Passamos, aqui, para o estilo e opção de vida, opção essa que se dá, é claro, dentro de limites e não é, de forma alguma, livre, pois está inserida 
em todo um contexto sócio-histórico (que, se não está em primeiro plano, tem de estar ao menos, como pano de fundo em qualquer estudo em Psicologia Social). Fala-se, aqui, do estilo hippie. A jocosidade se intensifica ao ponto do desrespeito pelas pessoas, tratando-os como desprezíveis animais, bichos mesmo, cujo habitat são "feiras de artesanato, grêmios estudantis, shows de música latino-americana e quitinetes de fundos, penumbrosas (...)", “(...) nesses cubículos, o ar (...) de incenso (...)”. Como todo bicho tem uma linguagem, a desses é o "balbuciar", e sua dieta é de baixo valor proteico, talvez um dos fatores envolvidos em seu processo de extinção. Acampam para acasalar, onde fumam "longos e grossos cigarros duma erva mística" (alusão à maconha), e, daí, resultam filhos "com nomes de Cachoeira, Pedra, Melado, Capim, por aî". Têm grande capacidade de regeneração, sobrevivendo “(...) até a extirpação de membros importantes, como Jim Morrison e, recentemente, Kurt Cobain”. Esses "extirpados", entretanto, sequer foram "hippies", o que talvez ateste, provavelmente, mais a falta de conhecimento desse fato por parte do autor - fazendo-o, assim, menos "maldoso" — do que o uso consciente dum outro artifício manipulatório (a estratégia de generalização, que podemos constatar em toda a série). Jim Morrison, poeta e vocalista da banda de rock americana The Doors, entre 1966 e 1971 (ano de sua morte), foi considerado inimigo público $\mathrm{n}^{\circ} 1$, após sua prisão, durante um show, por ter se extremado em seu comportamento, considerado, na época, como demasiadamente lascivo e irreverente e que ocasionou a "Cruzada pela Decência", apoiada pelo então presidente Richard Nixon, em 1969. Era, portanto, uma figura contestatória e política, e, como tal, indesejável à sociedade dita civilizada. Kurt Cobain, líder da também americana banda Nirvana, que se suicidou em 8 de abril de 1994, tragado pela era da MTV Music Television, foi o representante-mor do mundialmente conhecido "movimento grunge" (sobre o qual a voraz indústria da moda rapidamente lançou suas garras), em Seatle, EUA. Ambos têm sua morte comemorada por pessoas do tipo do jornalista do texto em questão, que torce pelo "suicídio coletivo" desse tipo de gente, ou, melhor dizendo, desse tipo de "bicho", desajustados e marginais além do tolerável. O recado é o seguinte: Quem não se adapta ao sistema precisa ser extirpado!

\section{O jornalista boêmio}

A espécie está virtualmente extinta, mas um pequeno vestígio, o paletó, mostra que ela ainda sobrevive.

Muitos historiadores da imprensa brasileira defendem a tese de que o jornalista boêmio já não é uma espécie em extinção: está tão extinto quanto um glipdonte - aquele tatu pré-histórico que parecia um fusca. Um detalhe, porém, intriga os mesmos historiadores: o paletó do jornalista boêmio. Se ele (o paletó) continua ali, onde sempre esteve, nas costas da cadeira atrás da mesa reservada ao jornalista boêmio, não estaria comprovado que ele o (jornalista boêmio) pode voltar à ativa a qualquer hora? A pergunta estimula a teoria de que o jornalista boêmio não está inteiramente extinto. Sobrevive, embalsamado em álcool.

Tanto sobrevive que aparece bissextamente na redação onde seu nome consta da relação de funcionários. Quem conseguiu avistar um jornalista boêmio durante o expediente - uma raridade, quase uma benção - sabe que, embora nunca saia de casa sem o paletó, jamais o veste. Quem o veste é justamente a cadeira do jornalista boêmio para quem o traje é um truque e uma senha. $\mathrm{O}$ paletó na cadeira informa não apenas que seu dono ainda não está extinto como, também, que embora não esteja lá, esteve e voltará a estar. Talvez, em breve. No momento, deve estar no banco, fechando durante o dia sempre curto buracos abertos por noites sempre longas. Ou, quem sabe, em algum de seus outros empregos.

O jornalista boêmio, enquanto profissional, a nível de companheiro, está sempre optando. Opta entre um emprego e outro. Opta entre uma frase iracunda de Brecht e uma citação agressiva de Brecht. Opta entre uma noitada inadiável e uma matéria inadiável - essa é, sempre, a opção mais fácil. Nesse caso, o jornalista boêmio alerta prontamente: "Optei!".

O jornalista boêmio também sempre sabe mais do que publica. Ou porque não escreve bem -“mas apura muito bem”, ressalvam colegas e parentes - ou porque a fonte transmitiu a informação não ao repórter, mas ao amigo. Para saber tudo o que o jornalista boêmio sabe, os leitores não devem procurar a página onde escreve (ou deveria escrever). Deve procurar o bar que frequenta.

Outra espécie de desajustados. Temos, nesse texto, uma alusão ao funcionário fantasma, aquele que não cumpre com seus deveres, presente especialmente, de acordo com o que muito se tem acusado, no serviço 
público (o qual sempre teve suas ineficiências realçadas pela imprensa, e seus funcionários, generalizadamente, tipificados como fantasmas). Indiretamente, ocultamente, o texto faz, com isso, propaganda das privatizações. O jornalista boêmio é alguém que vive, como repetidamente ressalta o texto, optando: "Optei!". Ora, "Optei" é um dos slogans, relativamente bem conhecido pelo público, do Partido dos Trabalhadores, o PT, oposicionista e favorito para as eleições de outubro de 1994. Por associação, então, liga-se a figura dessa mais uma abominável espécie em extinção ao referido partido (e, obviamente, aos seus partidários). Mais uma vez, o poderio ideológico utilizado num de seus meios prediletos (o que mais dá conta das relações de dominação social): o político. - "Não" às alternativas políticas!

\section{Síntese interpretativa}

Voltando a Thompson, ele nos diz que

interpretar a ideologia é explicitar a conexão entre sentido mobilizado pelas formas simbólicas e as relações de dominação que esse sentido ajuda a estabelecer e sustentar. (...) é um processo de síntese criativa (1, p.293)

Sintetizadamente, podemos identificar, nos textos estudados, todos os modos e estratégias da ideologia, além daquela estratégia que mais apontamos, que é a jocosidade e a ridicularização, às quais podemos agregar no modo dissimulação ("Brincando, brincando, a linguiça vai entrando") e, talvez, ainda num modo que poderíamos chamar de deslegitimação (baseado na descreditação e desclassificação de seus alvos). Além desses, há uma outra estratégia, também bastante usada nos textos, fundida com a jocosidade, que é o que podemos chamar de cientificização, que seria a colocação do que se está expondo como se fosse um conhecimento fundado cientificamente (por ex.: "Segundo cientistas...", "Pesquisas afirmam que..."); esta estratégia se enquadra na legitimação. Há, também, a rotulação ("labeling"), uma outra estratégia da reificação, atuando, conjuntamente, com a generalização (simbolização da unidade, servindo ao modo unificação). Outra estratégia ainda - se é que a podemos colocar como estratégia, mais do que como traço de caráter - seria a pretensão, que também se enquadraria na legitimação. Em tudo isso, procura-se uma cumplicidade com o leitor, colocando-se, direta ou indiretamente, no grupo do nós, um nós englobante, generalizador, quase que anônimo.

O título da série, Espécies em Extinção, é bastante explicitador e significativo. Nela, o expurgo do outro é mais que uma estratégia, mas quase uma lei geral no que concerne aos indesejados de fato (pois, na série, há, a um nível de certa dissimulação, a apresentação de pseudo-indesejados, isto é, fracamente indesejados, como é o caso do "yuppie" e do "noivo", onde o que realmente representam não é indesejado). Pensamos que, dentre os cinco textos, o do "jovem comunista" e o do "bicho-grilo" são os que mais trazem uma carga ideológica. O segundo texto, o do "noivo", é quase como uma dissimulação, uma amenização da série, buscando, com a tentativa de conquista da simpatia e confiança do público, legitimidade e consenso acerca da mesma. Após o texto do "noivo", a sequência vem com toda a força ideológica (o "Jovem comunista").

Um ponto central é que todos eles são postos como sendo, essencialmente, anacrônicos, e, como tal, devendo ser abandonados a um passado esquecido. São, assim, coisas ultrapassadas, que não tem mais lugar na sociedade atual, pós-moderna. Têm um caráter extremamente normatizador, ditando o que deve ser extirpado e, por conseguinte, o que deve ser cultivado. Exercem, duma posição absolutista e de dona da verdade, o julgamento sobre o que é bom e o que é mau. Sonham com um juízo final em que esses maus sejam condenados, livrando os bons de seu incômodo convívio, e, na medida do possível (e dos limites máximos do admissivel), não poupam esforços para adiantá-lo e concretizá-lo.

\section{A dimensão ética}

Tendo em vista o lugar de importância e de poder que ocupam os meios de comunicação de massa, não se pode deixar de lado a problemática ética. Uma das características dos meios de comunicação de massa, como mediadores da cultura, é que se inseriu, com eles, uma ruptura entre a produção/transmissão e a recepção/apropriação de formas simbólicas (1). Nessa ruptura, temos uma relação basicamente unidirecional, onde as pessoas que recebem tais meios ficam bastante restritas à passividade. De fato, sendo os meios de comunicação de massa privados, a liberdade de expressão (a liberdade de imprensa, por ex.) é muito limitada. Quem determina o que, 
como e quando algo deve ser produzido/transmitido é, em última instância (e, muitas vezes, em primeira), quem detém a propriedade do meio de comunicação. E, se quem trabalha nessa produção/transmissão já está subordinado aos grandes ditames, quem unicamente os recebe está quase numa posição de subjugação, pois, caso se sinta ultrajado e indignado com algo, muito pouco pode fazer (pode, no máximo, rasgar, pisotear e queimar o jornal, ou dar um tiro na televisão, ou ainda mandar surdas cartas de protesto, que, talvez, possam até servir de chacota na redação ou de material para uma outra publicação do gênero). A série de textos em questão, repetindo o que muito se faz nos meios de comunicação de massa, afirma valores sem os pronunciar (muitas vezes, dizendo que algo é ruim, deixa implícito o que é bom - ou nem tão implícito assim: o que é bom é o que não é ruim como isso) e, praticamente, não permite pronunciamento de defesa. Eticamente falando, comunicação é um serviço público, isto é, deve estar a serviço da comunidade. A comunicação privatizada, como é o caso do Brasil, onde a comunicação é um bem irrestritamente particular, fere esse direito humano à comunicação, pois só algumas podem dizer sua palavra, mostrar o que pensam, dar suas versões da realidade... Constitui-se, desse modo, em relações antiéticas, despejando, pelo poderio que compreende, produções manipulatórias, visões de mundo, tendenciosidades etc.

Tais produtos ganham significância na medida em que são apropriados no quotidiano, entrando, então, no permanente processo de constituição da identidade (inseparavelmente pessoal e social). A responsabilidade ética dos meios de comunicação de massa, por isso, é muito grande. O jornal do tipo do que está em questão é, em nossa sociedade, um bem de consumo de elite, cujo consumo depende de critérios econômicos e culturais; dentro do referido jornal, a seção em que foi publicada é a mais elitizada. Resultado: atinge, basicamente, a elite, que, constitutiva da parte favorecida e dominante da sociedade, tem o conservadorismo incentivado e alimentado.

O potencial crítico da HP (1) leva, para além dos conflitos de interpretação, à questão da justiça social. Nas palavras de Thompson, a reflexão crítica “(...) está interessada não com a pergunta 'Essa interpretação é correta?', mas, antes, com a pergunta 'Essas relações sociais são justas?"” (1, p.325). Leva, portanto, também a uma dimensão ética e política. Está implicada com a conscientização e com o agir relativos às situações e condições de vida das pessoas. Além disso, é inerente ao viver o compreender e o interpretar, constituintes do existir humanamente (inclusive, como diz Ciampa (2), a interpretação do que vale ou não a pena ser vivido). As pessoas que vivem em condições subumanas, a "categoria dos excluídos" (3), em alarmante número, é que estão, hoje e agora mesmo, extinguindo-se, sucumbindo a tais condições. Ao invés de desejar e buscar a execração do marginal e do indesejado ao status quo, esperamos que a estrutura que mantém tal situação é que se extinga, e, aqui, incluo atitudes como as descritas nos textos estudados, definitivamente incongruentes e anacrônicas (além de nauseantes, indignantes e fascistóides). Podemos traduzir a mensagem geral da série, que colabora com a construção e reforçamento de preconceitos, como um prenúncio - e um desejo - dos poderosos (que talvez se julguem deuses divinos e onipotentes): - O juízo final está chegando!

God save the people.

\section{Notas}

1. Quando da elaboração deste trabalho, a série dominical "Espécies em Extinção" estava em pleno curso, e assim continuou por um bom tempo - até a matéria suprema do domingo de 23/04/95, assinada pelo Sr. Eduardo Bueno, pondo fim à mesma após um ano de seu início e fazendo um balanço, esbanjando o característico ritmo despreocupadamente eufórico (para não dizermos, por exemplo, oligofrênico) e debochado, das 45 "espécies em extinção" honradas por tal iniciativa e das reações de protesto (incluindo ameaças) que chegaram à redação (e até das reações que eram esperadas, mas que, lá, não chegaram). Citemos algum trecho: "Durante 47 semanas, os leitores da Revista $Z H$ se depararam, todo domingo, com o diagnóstico de um grupelho, uma seita, uma tendência ou uma tribo - algumas francamente inofensivas, outras decididamente perigosas (...) E 'extinção é para sempre' - felizmente, no caso da maioria das espécies selecionadas por Zero Hora. (...) Disposta a ser politicamente incorreta - justamente porque, apesar de sincera, jamais deixou de ser cínica - a sessão nunca fugiu da polêmica" (A título de curiosidade, a matéria traz uma lista com 45 espécies - ou isso foi por lapso na lista, ou a ânsia de proclamar e pregar tais extinções fez com que saísse "47 semanas", 
a não ser que duas delas [ou uma, por duas vezes] tenham sido privilegiadas em mais duma semana). Deveras inteligente.

2. A sequência escolhida da série foi a correspondente às cinco semanas exatamente anteriores àquela em que este trabalho foi elaborado.

Referências bibliográficas:

1. THOMPSON, John B. (1990): Ideology and modern culture: Critical Social Theory in the Era of Mass Communication. California, Stanford University Press, 362p. (a tradução, feita pelo grupo de pesquisa em Ideologia, Comunicação e Representações Sociais, PUCRS, com coordenação do Prof. Pedrinha A. Guareschi - PhD, deverá ser lançada pela Editora Vozes em meados de 1995).

2. CIAMPA, Antônio da Costa. (1987): A estória do Severino e a história da Severina. São Paulo, Brasiliense, 246p.

3. GUARESCHI, Pedrinho A. (1992): A categoria 'excluído'. Psicologia Ciência e Profissão, Brasília, Ano 12, n. 3 e 4.

4. PIRES, Luiz Zirú. Yuppies. Revista ZH, Zero Hora, Porto Alegre, 08/5/94.

5. BUENO, Eduardo. O noivo. Revista ZH, Zero Hora, Porto Alegre, $15 / 5 / 94$.

6. BUENO, Eduardo. O jovem comunista. Revista ZH, Zero Hora, Porto Alegre, 22/5/94

7. MARTINS F ${ }^{o}$, Cyro Silveira. O bicho-grilo. Revista ZH, Zero Hora, Porto Alegre, 29/5/94.

8. BUENO, Eduardo. O jornalista boêmio. Revista ZH, Zero Hora, Porto Alegre, 05/6/94.

\section{IURD: religião, poder e dominação}

Fátima O. de Oliveira

PUCRS

Graziela C. Werba

PUCRS

Introdução

O tema deste estudo liga-se ao projeto de pesquisa "A palavra como dominação: o uso da comunicação - verbal e eletrônica - nas práticas de diversos grupos religiosos", do professor Pedrinho Guareschi, do qual somos bolsistas de iniciação científica.

A principal motivação em realizar este trabalho relaciona-se ao conceito "território de fantasia", que será discutido e analisado sob dois enfoques - psicossocial e psicanalítico. A interação entre estes dois campos não só mostrou-se possível, como necessária, para se começar a entender este fenômeno social que é o movimento religioso neopentecostal no Brasil, em particular, a IURD (Igreja Universal do Reino de Deus).

Entendemos que este estudo assume especial relevância num momento histórico em que vemos uma sociedade confusa, com paradigmas sociais, políticos, econômicos e religiosos contraditórios. É neste contexto histórico da pós-modernidade que iremos encontrar um crescimento da tensão social e um ambiente propício ao incremento de necessidades humanas diferentes e talvez por isso, um aumento do surgimento de instituições religiosas e místicas que tentam oferecer uma resposta a este espaço místico, a esta dimensão transcendental do ser humano.

Este estudo se compõe de três capítulos: I) Elementos históricos e metodológicos; II) Discussão de alguns elementos teóricos e III) Análise interpretativa dos dados.

\section{Elementos históricos e metodológicos}

É investigada a comunicação dos pastores da IURD nas igrejas e nos programas de TV por ela veiculados no canal 10, TV Bandeirantes, RS, 
Brasil. Privilegiamos, no estudo, a dimensão ideológica. Entendemos a ideologia como o uso de formas simbólicas para criar e manter relações de dominação (Thompson, 1990).

O trabalho a princípio, iria basear-se em entrevistas e aplicação de questionário tanto para os pastores quanto para os fiéis da IURD. No entanto, não foi possível concretizar tal plano, uma vez que ao chegarmos ao local das entrevistas, o pastor da IURD desprezou a carta de apresentação da Universidade, negou-se a responder e não permitiu que tivéssemos acesso aos fiéis dentro da igreja.

Diante desta dificuldade, usamos uma metodologia de estudo exploratório e observações participativas, seguindo uma abordagem qualitativa. A quantidade de observações que conseguimos, fruto do trabalho de mais de um ano, ajudou a esclarecer as seguintes questões norteadoras que formulamos, sem com isto esgotar este instigante estudo:

- Quais os mecanismos de comunicação usados para captar e manter adeptos e se entre estes mecanismos é utilizado algum tipo de persuasão no sentido de criar ou reproduzir a dominação?

- De que forma a igreja penetra no "território de fantasia" do ser humano e que uso é feito dele?

- O que a igreja entende por beneficio? Esta realidade coincide com o que os fiéis esperam da instituição?

- Como é utilizado o processo de identificação, entendido dentro do referencial psicanalítico?

- Qual a imagem que a igreja transmite de Deus? Esta imagem é cerceadora ou incentivadora das qualidades criativas e libertadoras do ser humano? Esta imagem é trabalhada em um nível concreto e/ou simbólico?

Foram realizadas três observações participativas e entrevistas de caráter informal.

Foi feito também um acompanhamento diário do programa eletrônico — "O Despertar da Fé", da IURD, que foi registrado em fitas de vídeo cassete. A observação diária do referido programa, ocorreu do período de maio de 1992 até novembro de 1993.
O programa, de forma geral, se compunha de três partes, sendo desenvolvido por três comunicadores que se autodenominavam pastores. Antes da primeira parte, e depois da última, entrava uma vinheta com o logotipo do programa "O Despertar da Fé” com fundo musical específico.

A partir de setembro de 1992, houve uma mudança, na estrutura do programa. Foram introduzidas imagens dos cultos ao vivo. Eram flashes com depoimentos de fiéis, na própria igreja. Surgia um novo pastor que lia e respondia as cartas enviadas ao programa. Elas eram lidas, respondidas e o remetente convidado a ir até a igreja. Outro elemento novo introduzido foi o pedido do dízimo, que a partir destes programas passou a ser solicitado através de textos da Bíblia.

A primeira parte iniciava com um dos pastores dando o "bom dia" e falando sobre os sofrimentos humanos. Era escolhido um tema como por exemplo: problemas conjugais, doença, falta de dinheiro. O pastor iniciava então um "bombardeio verbal" e terminava apontando a IURD como a solução infalível para aquele determinado problema. A fala era rápida e sem pausa.

$\mathrm{Na}$ segunda parte do programa outro pastor era convidado pelo primeiro a entrevistar uma terceira pessoa que estava ali para dar o seu "testemunho da fé". Enquanto um pastor ia induzindo a pessoa a falar, ou melhor, a contar seus problemas revelando os mais' íntimos detalhes, o outro fazia intervenções.

Frases como "agora tenho Jesus no coração"; "agora sou feliz"; "tudo em minha vida mudou"; e o chavão "graças a Deus" eram ditas massivamente durante os 30 minutos do programa. Esta parte terminava com o pastor analisando a experiência do entrevistado, reforçando como a igreja fora a solução do problema e como a pessoa estava agora feliz.

A terceira parte do programa iniciava com um dos pastores segurando um copo de água e ao fundo imagens superpostas sucessivamente. Eram imagens de elementos da natureza em close. O pastor erguia o copo, fechava os olhos e começava uma oração. Este ritual devia ser repetido pelo telespectador e a água devia ser tomada ao final da oração. O pastor dizia: "beba desta água sagrada e diga graças a Deus", a água era milagrosa, segundo ele. Depois de tomar alguns goles da água, o pastor se despedia, convidando o telespectador a ir à igreja e a assistir ao próximo programa. 
As pessoas chamadas a testemunhar nos programas, eram geralmente praticantes de outras religiões, que não a católica, que se tinham convertido à IURD. Em geral eram pessoas cujo histórico continha experiências com familiares próximos alcoolistas, com maus tratos, drogas, prostituição, dificuldades no relacionamento familiar, social, problemas econômicos e de saúde.

Em relação aos problemas de saúde, havia relatos de cura de câncer, epilepsia, depressão, drogas, infertilidade e até AIDS.

Quanto à comunicação não verbal, além das imagens, slides com elementos da natureza, é importante frisar que os pastores eram todos jovens, aparentando idade entre 30 e 40 anos, bem vestidos, estilo jovem executivo. As pessoas entrevistadas no programa, geralmente não fugiam a esta regra. Durante todo o programa piscava no vídeo o endereço e telefone das igrejas em Porto Alegre, Novo Hamburgo, Canoas, Sapiranga e S. Leopoldo. As vinhetas eram muito bem elaboradas e o logotipo frequentemente apresentado.

A comunicação verbal era explorada em vários aspectos: o ritmo das palavras dos pastores muito intenso, sem quase se perceber as pausas; as mensagens repetitivas e reiteradas; a linguagem simples e identificada com o público alvo - classe popular; a entonação de voz era de pregação.

Discutiremos a seguir no capítulo II, alguns conceitos teóricos que nos auxiliarão na análise interpretativa dos dados, que faremos no capítulo III.

\section{Discussão de alguns elementos teóricos}

Para melhor compreensão e interpretação dos dados, discutimos aqui alguns conceitos teóricos que se mostraram úteis e até necessários para esse empreendimento.

\section{A Psicanálise e os grupos}

Freud, (1959) em A Psicologia das Massas e Análise do Ego classifica a Igreja e o Exército como massa artificial. As massas artificiais são as que necessitam de coesão exterior. São duradouras e altamente organizadas. A coesão externa tem como objetivo preservar e evitar modificações na sua estrutura.
Para Freud, tanto a Igreja quanto o Exército têm em comum a ilusão da presença visível ou não de um chefe que ama a todos os membros do coletivo com o mesmo amor. Esta ilusão, seria a principal fonte de manutenção da massa, e não apenas a sugestão, como pensava Le Bon e outros autores anteriores a Freud. De acordo com Freud, o indivíduo dentro da massa, encontra-se unido duplamente por laços libidinosos: por amor ao chefe e por amor aos membros da coletividade.

Em A Massa e a Horda Primitiva (1959), Freud parte da hipótese de Darwin, da horda sob o domínio de um poderoso macho e tenta demonstrar que aquela organização primitiva deixou traços na história da humanidade. Seria desta horda com seu líder absolutista que iriam evoluir a religião e a moral, como as conhecemos hoje. Os indivíduos estariam ligados por laços libidinosos da mesma forma que hoje, mas o chefe estaria ligado sobretudo a si mesmo, de uma forma narcisista, amando aos outros apenas enquanto estes serviam para satisfação de suas necessidades. Enquanto os indivíduos da coletividade acreditam que o chefe ama igualmente a todos, o chefe, por sua, vez não precisa amar a ninguém e mantém-se narcisista. $\mathrm{O}$ narcisismo limita o amor e torna-se, então, um importante fator de civilização.

Baseado nestas ideias sobre a horda primitiva, Freud demonstra como ocorrem os fenômenos da hipnose e sugestão. A hipnose traria à tona um elemento reprimido, antigo e familiar, despojando o sujeito de sua vontade. Trata-se de uma força misteriosa que os primitivos acreditavam emanar dos chefes e representava um tabu. Para estes primitivos, o hipnotizador era um chefe dotado do poder de dominar através do olhar, da mesma forma que, o crente vê, mais tarde, a Deus.

Segundo esse autor, a hipnose pode ser provocada também por outros meios, inclusive pelo som. Na verdade, são processos que têm como objetivo, desviar e fixar a atenção consciente em alguém, no caso, o hipnotizador, com quem o hipnotizado entra em estado de transferência. A transferência, então, pode estabelecer-se de acordo com a "imagem do pai", como disse Jung (1984), ou com a imagem da mãe ou irmão, através de representações libidinais conscientes e inconscientes. Para Freud (1959), a transferência é um fenômeno que pode ocorrer tanto na psicanálise como fora dela, podendo, no último caso chegar até a submissão mais absoluta, demonstrando que este processo ocorre não por causa da psicanálise e sim em função da própria neurose. 
Segundo Zimerman (1992), em qualquer grupo, seja terapêutico ou não, ocorrem manifestações transferênciais. Nas grupoterapias, o autor identifica quatro níveis desta manifestação; 1) transferência parental, de cada indivíduo para a figura do grupo terapeuta; 2) transferência grupal, do grupo como um todo em relação a figura central; 3) transferência fraternal, de cada individuo em relação a outro indivíduo; 4) transferência de pertença, de cada indivíduo em relação ao grupo como entidade abstrata. Os quatro níveis de transferência podem se processar simultaneamente, embora em alguns momentos um possa prevalecer com maior nitidez.

Ferenczi (in Freud, 1959), conclui que o hipnotizador ao ordenar que o hipnotizado durma, coloca-se no lugar dos pais deste. Outra ideia é que existem duas classes de hipnose; uma "acariciante, apaziguadora" que seria a maternal e outra "ameaçadora" que seria a hipnose paternal. Para Ferenczi, a ordem de dormir significa um convite para que o hipnotizado dirija seu interesse exclusivamente ao hipnotizador, desviando a atenção do mundo externo da mesma forma que ocorre com o sono, quando a pessoa desliga-se do mundo exterior. Desta maneira o hipnotizador desperta algo da herança arcaica do hipnotizado "relembrando-o" do pai onipotente para quem só poderia colocar-se em atitude passiva/masoquista.

Outro conceito importante para a compreensão do estudo em questão, é o de catarse. ${ }^{1}$ Freud, em Estudos sobre a Histeria, desenvolveu a teoria de que "os afetos que não conseguiram encontrar o caminho para a descarga ficam presos, exercendo então efeitos patogênicos"(Freud in Laplanche, 1992: 60-62). No princípio, o método catártico estava ligado à hipnose, reservando a catarse para uma classe de menor importância dentro da psicanálise. Porém, a catarse permanece um conceito significativo dentro da psicoterapia analítica, sendo utilizada inclusive por outras técnicas, como o psicodrama, na liberação dos conflitos interiores por meio da representação dramática.

\section{A psicossociologia dos grupos}

Em “Sociologia da Comunicação”, Gabriel Cohn (1973) define o termo "massa" como "uma coletividade de grande extensão, heterogênea,

\footnotetext{
${ }^{1} \mathrm{O}$ termo Catharsis vem do grego e significa purificação, purgação. Foi usado por Aristóteles para designar o efeito produzido pela tragédia.
}

quanto à origem social e geográfica dos seus membros e desestruturada socialmente" (Cohn, 1973 p 17).

Segundo ele, o fenômeno social "massa" passa a ser objeto de estudo no pensamento político conservador do sec. IX e como reação à Revolução Francesa, tendo assumido portanto uma conotação reacionária contrária ao conceito de massa utilizado por Marx: ao analisar o golpe de Luís Bonaparte. (1973: 19) diz que

Em 1895, Gustave Le Bon, em sua obra "Psicologia das Massas"

o mais singular dos fenômenos apresentados por uma massa psicológica é o seguinte: quaisquer que sejam os indivíduos que a compõem e por diversos ou semelhantes que possam ser seus gêneros de vida, suas ocupações, seu caráter ou sua inteligência, o fato exclusivo de se acharem transformados numa multidão torna-os possuidores de uma espécie de alma coletiva. Esta alma fá-los sentir, pensar e agir de uma maneira inteiramente diferente de como sentiria cada um deles isoladamente. (Le Bon in Freud, 1959: 8).

A análise de Le Bon apresenta a massa desprovida de racionalidade, dotada de impulsividade e atitudes regressivas. Le Bon utiliza os termos massa e multidão alternadamente não diferenciando especificamente nenhum agrupamento humano. A classificação de Le Bon refere-se a multidões heterogêneas e homogêneas. As heterogêneas podem ser anônimas (como agrupamentos de rua). Homogêneas, não anônimas, como júris, assembleias, seitas (políticas e religiosas), castas (militares e religiosas), trabalhadores e classes sociais.

Cohn faz uma distinção entre Freud e Le Bon no que se refere ao entendimento da massa. Le Bon apresenta a massa ou multidão propensa à explosão de impulsos associais contrariamente a Freud, que entende a massa como uma forma básica de constituição de vínculos sociais, o que em última análise, sustenta o aparecimento da cultura. Cohn diz ainda que a noção de cultura de Freud, construída sobre a coerção e renúncia dos impulsos individuais, antissociais e anticulturais, denota um matiz conservador cujo tema subjacente é a dominação.

\section{O processo de identificação nos grupos}


Para Freud, identificação seria um gênero de ligação afetiva que nos permite compreender o processo de fixação a um determinado objeto, mecanismo pelo qual os indivíduos se ligam a um chefe e entre si.

De acordo com Guareschi (1992:178)

(...) pode-se dizer que há na subjetividade de uma pessoa duas dimensões. A dimensão individual, que se pode chamar de egoideologia; e a dimensão social, que se poderia chamar de alteroideologia. Assim a interpelação do sujeito se daria em duas direções: interpelação com respeito à posição do sujeito como tal, ao papel que ele desempenha: identidade, consciência de si, ego-ideologia; e interpelação do sujeito com respeito aos outros da posição: consciência social de classe, altero ideologia.

A segunda dimensão refere-se a forma de perceber e relacionar-se com os outros, com outras identidades. E assim que se dão as relações de poder e dominação. Guareschi cita Freire: "os oprimidos introjetam a imagem do opressor" (Guareschi, 1992: 179), bem como seus valores, crenças e visão do mundo, inclusive sua identidade quanto ao modo de produção capitalista.

Segundo Oro (1992), uma prática usual na IURD é a identificação das pessoas que já foram de alguma forma agraciadas pela religião. É comum durante os cultos os pastores solicitarem que levantem a mão aqueles que já alcançaram alguma graça, e a maioria das pessoas se manifesta.

Segundo Zimerman (1992:88), a igreja foi utilizada por Freud como um modelo de liderança que se processa através do fenômeno introjetivo; de acordo com o autor, a palavra religião se forma a partir de "re" e "ligare", ou seja, como uma nova tentativa de ficar ligado, fundido com Deus, o que por sua vez, é uma fusão simbólica da mãe primitiva e do pai todo poderoso.

O líder carismático de uma massa primitiva corresponde a uma fase evolutiva muito regressiva, de natureza narcisista-simbiótica, em que ainda não se processou a diferenciação entre o eu e outro.

Bion, através de estudos, provou que qualquer grupo tem uma necessidade implícita de que haja uma liderança. Ele fundamentou a postulação de que o líder é um emergente do grupo, diferente de Freud, que considerava o grupo como um emergente do líder.

Diz Zimerman, que num sistema familiar, institucional ou social os grupos podem se comportar como uma estrutura onde ocorre uma distribuição de papéis e posições que se complementam. "Podemos dizer que em cada papel se condensam as expectativas, necessidades e crenças irracionais de cada um e que compõem a fantasia básica inconsciente comum ao grupo todo" (Zimerman, 1992:86).

Elliot Jaques, (1969) levanta a hipótese de que um dos elementos coesivos primários que reúnem pessoas em associações institucionalizadas, é o da defesa contra a ansiedade psicótica. Ocorre que os indivíduos projetam para o exterior os impulsos e objetos internos que de outra forma se transformariam em ansiedade psicótica e os associam à vida das instituições às quais se agregaram (Jaques in Melanie Klein et alii, 1969). Por isto é comum encontrar-se nas relações grupais manifestações e comportamentos desadaptados, da mesma forma que nos indivíduos se observam sintomas psicóticos. Desta maneira, os indivíduos usam as instituições e inconscientemente reforçam suas defesas contra a ansiedade e culpa; entre estes mecanismos destaca-se a dissociação, que permite ao indivíduo separar os bons objetos dos maus objetos em diferentes espaços. 


\section{A persuasão como técnica de dominação através da comunicação}

Vivemos na era da persuasão. Os progressos da técnica tem favorecido esta forma de ação do homem sobre o homem. Bousquié (1961) diz que, há muito se tem estudado as formas de persuasão para satisfazer as exigências da arte da oratória, tão comumente usada por vendedores, advogados, políticos e religiosos. A persuasão pode ser uma arma formidável se bem empregada, além da conversação, conta ainda com a imprensa, rádio, TV que auxiliam na persuasão das massas. Para este autor, a informação é um domínio estéril se não for acompanhada da persuasão. Pode-se dizer que persuadir é o triunfo da palavra. A persuasão não utiliza somente a linguagem falada, mas esta é sua forma mais eficaz.

A persuasão não deve ser um meio de exercer pressão para enganar o indivíduo, embora às vezes seja mal empregada.

Porém, como dizia um antigo filósofo: Quando uma coisa pode igualmente prejudicar e favorecer não deve-se considerá-la má, e sim que sua bondade eu maldade depende do uso que dela se faça (1961: 7).

Ainda conforme esse autor, deve-se distinguir a diferença entre convencer e persuadir. A convicção age sobre o entendimento; a persuasão sobre a vontade.

Ao tratar de comunicação, é necessário considerar três elementos: $o$ emissor, a mensagem emitida e o receptor da mesma. Quanto ao emissor, deve-se considerar suas qualidades físicas, seus dons, seu carisma e seus gestos no momento da ação persuasiva, pois isto é fundamental para seduzir o receptor. Uma boa tática é o emissor falar de si mesmo e do próprio grupo que lhe escuta, assim surge o interesse, identificação e amor próprio, proporcionando um movimento voluntário de reflexão acerca do que se trata. O persuasor induz os demais a saírem do seu mundo fechado individual, para solidarizar-se com ele. Esta harmonia conseguida prepara uma imitação ativa.

Bousquié entende que a persuasão, como esforço de criação de um campo de influência, supõe três condições: 1) o conhecimento do espírito humano; 2) o que faz mover o homem (sentimento ou razão); 3) o conhecimento das diferentes formas de falar aos diferentes grupos. $\mathrm{O}$ pensamento deve ser exposto de maneira simples e acessível e se necessário recorrer a imagens ou gestos. Na prática da persuasão, alguns elementos físicos também devem ser considerados, por exemplo, a voz, os gestos e a aparência do persuasor. Quanto aos gestos, pode-se garantir que são tão importantes quanto a voz; estes por sua vez devem estar de acordo com as palavras.

Bousquié finaliza dizendo que a TV é um excelente meio para se persuadir. O telespectador geralmente se encontra comodamente sentado e passivo, e a cadência das imagens levam-no a um estado de relaxamento. Neste momento o telespectador, isto é, o receptor se concentra num espetáculo audiovisual e se deixa guiar. Quanto à mensagem, discutir-se-á mais adiante.

\section{Ideologia e religião}

Para Guareschi (1989), toda sociedade necessita garantir sua sobrevivência, permanência e reprodução. A produção garante a sobrevivência e os diversos aparelhos, ou instituições, são mecanismos que garantem a permanência e reprodução dessa sociedade. Os aparelhos de reprodução podem ser classificados em repressivos e ideológicos. Os aparelhos ideológicos são aqueles que na sua função de reprodução das relações numa sociedade, fazem uso da persuasão e da ideologia. Entre estes, pode-se citar: a escola, a família, as igrejas, os meios de comunicação e outros.

É importante, para compreender melhor o estudo a ser realizado, distinguir com precisão, poder e dominação (Guareschi, 1992: 56-59; 125129). Pode se definir poder como sendo a capacidade de uma pessoa, ou de um grupo, para executar qualquer ação ou exercer qualquer prática. Nesse sentido todos têm algum poder, à medida em que podem fazer alguma coisa. Já a dominação é definida como sendo uma relação entre pessoas ou grupos, onde alguém expropria, rouba, se apodera de algum poder de outro; ou, por extensão, onde alguém, a pretexto de o outro possuir determinadas qualidades ou características (como o fato de ser mulher, ser de outra raça, de outra etnia, etc.), se apropria de seus poderes (capacidades) e passa a tratá-lo de maneira desigual. Na dominação, portanto, existe sempre uma relação assimétrica e desigual. 
Para se compreender como surge a dominação, é útil discutir um outro conceito importante: o conceito de Ideologia. Pode-se definir ideologia, como sendo o uso, o emprego de formas simbólicas para criar, sustentar e reproduzir determinados tipos de relações. Ideologia é o que vai dar sentido, significado às coisas, sua dimensão valorativa, podendo servir para criar e sustentar relações justas, éticas, de fraternidade, ou também para criar e sustentar relações assimétricas e injustas. Thompson (1990), usa o termo ideologia para designar apenas relações desiguais, injustas. É a acepção que também empregamos nesse estudo.

Guareschi (1985: 21-25 e 1985: 85-89), ao falar das igrejas como aparelhos ideológicos, situa os agentes religiosos (pastores, ministros, etc.), como situados num contexto histórico particular, mostrando a impossibilidade de neutralidade. Conforme este autor, há igrejas que muitas vezes servem aos interesses dos donos do poder e não denunciam a absolutização deste, não possuem uma postura critica diante do social e não mostram a dominação e repressão: são de tipo superestrutural, na conceituação de Enrique Dussel (1980). Neste caso, não causam incômodo a um regime dominador e é provável que estejam servindo a este. E no caso de igrejas que atribuem aos deuses a explicação do universo e a raiz de todos os males, ou colocam a solução de todos os problemas na entrega total a Jesus, deve-se questionar a quais interesses estes grupos estão servindo. (Dussel, 1980:86) Mas lembra também Guareschi (1989), que todos os aparelhos ideológicos, apresentam contradições: verifica-se através da história, igrejas a serviço do poder e a serviço da libertação.

\section{O território de fantasia}

Vimos a necessidade de buscar um outro conceito para poder explicar nossos dados. Decidimos chamá-lo de "território de fantasia", inspiradas numa crônica de Moacir Seliar (1991). Analisamos essa "realidade" em alguns autores.

Para Viktor Frankl (1987), encontrar um significado e um sentido de responsabilidade para a existência é imprescindível. $\mathrm{O}$ autor distingue várias formas de neurose e atribui algumas delas (as neuroses noogênicas) à incapacidade do indivíduo encontrar este sentido para a vida. Enquanto Freud acentua as frustrações da vida sexual; Frankl aponta a frustração do desejo de sentido e significado (1987: 8). Segundo ele, é necessário acreditar e carregar sempre alguém ou alguma coisa, sejam pessoas amadas, obras, sentimentos religiosos ou perspectivas de futuro para se vencer dificuldades. Ele cita várias vezes uma frase de Nietzsche: "quem tem por que viver pode suportar quase qualquer como". Acredita na capacidade humana de transcender sua situação difícil e descobrir uma adequada verdade orientadora (Frankl, 1987: 9-10). Afirma: "A liberdade interior do ser humano, a qual não se lhe pode tirar, permite-lhe até o último suspiro configurar a sua vida de modo que tenha sentido" (1987: 85). A angústia existencial, segundo ele, provém da preocupação da pessoa saber se sua vida tem ou não sentido, isto é, se vale a pena ser vivida. Para ele a vida realmente tem sentido quando conseguimos transformar criativamente os aspectos negativos em algo positivo. $\mathrm{O}$ ser humano não é alguém em busca da felicidade, mas sim alguém em busca de uma razão para ser feliz.

A busca de sentido pela vida deve partir de cada um; não se pode esperar que este sentido venha de fora para dentro, assim como a esperança, o amor e a fé não podem ser impostos ou exigidos.

Para Jung (1984), a religião constitui uma das expressões mais antigas e universais da alma por isso ao se estudar a estrutura psicológica da personalidade humana, deve-se considerar que a religião é um assunto importante para as pessoas, além de se tratar de um fenômeno sociológico e histórico. Segundo ele, a posição científica de um psicólogo não deve considerar o credo religioso como possuidor da verdade exclusiva e eterna, mas deve concentrar sua atenção no aspecto humano do problema religioso, abstraindo o que as confissões religiosas fizeram com ele.

Ainda segundo Jung (1984), o dogma constitui uma expressão da alma muito mais completa do que uma teoria científica, pois esta última só é formulada pela consciência, enquanto o dogma é como um sonho que reflete a atividade espontânea e autônoma da psique objetiva, isto é, do inconsciente. A religião que se instala na história de um povo, conforme Jung, é fruto da permissão deste, assim como do contexto sócio-histórico que este está inserido. A religião é uma relação voluntária ou involuntária com o valor supremo, seja ele positivo ou negativo, e esta relação pode estar em alguém que a tenha adotado consciente ou até mesmo inconscientemente. 
Denominamos a essa realidade específica de "território de fantasia", um espaço que se mostra real e necessário na vida das pessoas e grupos. Nossa análise assume a existência desse espaço, quer mostrar como ele pode ser usado não para beneficio das pessoas, mas em seu prejuízo.

\section{Análise interpretativa dos dados}

Discutiremos, primeiramente, o programa televisivo "O Despertar da Fé", para depois fazer uma análise global dos dados.

\section{Discussão do programa televisivo Despertar da Fé}

O programa inicia com um dos pastores falando sobre os sofrimentos humanos, como por exemplo, problemas conjugais, doença, falta de dinheiro, em estilo de pregação e usando como base de seu discurso o processo de identificação no que se refere ao conteúdo e na forma da mensagem. Os problemas são levados ao grau máximo de tolerância e a IURD é apontada como a solução infalível para aquele determinado problema.

Nas entrevistas com fiéis, percebe-se que os pastores mantêm a fala do convidado dentro de um limiar de controle da ansiedade; se esta aumentar, ameaçando a eficácia da mensagem, um dos pastores intervém e retoma a comunicação, desviando-a ou modificando-a conforme a situação.

Quanto ao público alvo do programa, a IURD busca invariavelmente atingir e sensibilizar pessoas praticantes das religiões afro-brasileiras. A tática usada é o reconhecimento da existência dos elementos destas religiões, como por exemplo: pomba-gira, espíritos malignos, pai de santo, macumba, e muitos outros, associados ao diabo. Com esta tática, os pastores permitem ao público uma identificação com toda uma linguagem muito familiar, "afrouxando" desta forma suas defesas, através de um pseudorreconhecimento de seus simbolismos, para sensibilizar a pessoa e cooptá-la para a igreja.

Uma técnica facilmente observável é o bombardeio exaustivo, quase que uma lavagem cerebral na pessoa, de que a crença praticada anteriormente é falsa e errada, pois nela a pessoa não prosperou. Fica implícito, nesta mensagem, que o sucesso financeiro de uma pessoa está diretamente vinculado à religião que pratica.

A comunicação é feita com um tom de intimidade, como se todos fossem conhecidos, pastores e telespectadores: "meu amigo, minha amiga, você que está em casa agora, deprimida..." O estilo de comunicação é de programa de entrevista popular, mesclado com marketing comercial e sensacionalismo.

Os aspectos psicológicos estão presentes em toda a estrutura do programa, desde a vinheta de abertura até o final. Há um clima de mistério, imagens cósmicas, visual atraente, música de fundo, apelo ao místico. Os comunicadores parecem ter recebido um treinamento específico para atuarem, pois todos trabalham da mesma forma, usando a mesma entonação de voz, o mesmo discurso. A própria estrutura do programa, muito bem elaborada e organizada, indica uma preocupação com o aspecto psicológico.

No desenvolvimento do programa, inicia-se com a pregação, depois passa para o momento de maior ansiedade, onde ocorre o processo de identificação do telespectador com o entrevistado. Ao final da entrevista há uma "devolução" com a "solução" do problema. A finalização do programa acontece com um salmo, que tem sua locução feita pelo jornalista Cid Moreira, ${ }^{2}$ ficando sempre como última imagem uma mensagem positiva. Pode-se perceber aqui alguma semelhança com a técnica utilizada pela seita Seicho-No-Iê.

Pelas observações realizadas na IURD, foi possível constatar que o público frequentador é na sua maioria de nível educacional baixo, sem uma definição política clara. Estas características, por vezes acrescidas de um baixo rendimento intelectivo, produzem a vítima fácil das igrejas eletrônicas. De uma forma geral, observa-se por parte dos frequentadores da IURD, um comportamento ligado a ideias onipotentes e todo um pensamento mágico. 


\section{Análise geral da investigação}

Os elementos teóricos dão-nos uma base suficientemente sólida para iniciar uma discussão, sem entretanto pretender esgotar um tema tão complexo. Uma das características do ser humano é sua dimensão transcendental, sua abertura ao mistério. A espécie humana tem, comprovadamente, uma necessidade psicobiológica de um espaço em sua vida mental que chamamos de "território de fantasia". Desde que se reconhece como ser vivo, o homem expressa, de alguma maneira, seu sentimento, sua espiritualidade ou religiosidade. Esta capacidade de transcendência dota a humanidade de uma característica criativa. Da caverna ao mais moderno conjunto arquitetônico, a história faz o registro do encontro do homem com seu misticismo.

A sociologia, antropologia, psicologia e a medicina demonstram que o ser humano precisa, em algum momento, ceder à racionalidade e deixarse perder em algum paraíso misterioso, em um território de fantasia. Esta necessidade tão humana de fantasiar, crer e ter fé está profundamente vinculada ao sentimento religioso das pessoas. Alguns têm fé em totens, como no início da história da humanidade, outros têm fé em ideias e há aqueles que incondicionalmente devotam-se à crença no lucro econômico.

A questão que se coloca a partir do conjunto destes elementos é de que forma o homem trabalha seu território de fantasia? Que recursos internos e externos utiliza para alcançá-lo?

A fé e o sonho, contudo, tão importantes na manutenção da saúde física e mental, precisam da companhia da consciência política. Sem estas ferramentas, a pessoa passa a ser objeto de manipulação, pois deixa de exercer seu poder. Neste momento começa a ocorrer a dominação. Quando dominado, o homem torna-se infeliz, pois deixou de se pertencer. Esta desapropriação, esta alienação da consciência ao outro, também é uma patologia, é uma doença social.

Em um país politicamente desestruturado, economicamente desestabilizado, ideológica e eticamente deturpado, encontra-se um terreno fértil para a alienação. É neste contexto que constatamos a proliferação de uma forma especial de dominação: a exercida pelas igrejas neopentecostais. Após dois anos de pesquisa diária, seja através da observação dos programas eletrônicos, como indo a campo colhendo dados e materiais (enxofre, sal grosso, água e material gráfico), seja através da revisão bibliográfica, pretendemos aprofundar à luz da psicologia social, o fenômeno das igrejas neopentecostais, especificamente a IURD.

\section{Em O Futuro de uma Ilusão, Freud afirma:}

Admite-se que até agora, a ciência ainda não conseguiu muita coisa, mas mesmo que progredisse mais, não bastaria para o homem. Este possui necessidades imperiosas de outro tipo, que jamais poderiam ser satisfeitas pela frígida ciência sendo muito estranho na verdade, o auge da incoerência, que um psicólogo que sempre insistiu em que a inteligência, quando comparada à vida dos instintos, desempenha apenas um papel de menor vulto nos assuntos humanos, tente agora despojar a humanidade de uma preciosa realização e proponha compensá-la disso com um alimento intelectual (1927-1931: 48).

Podemos depreender destas palavras, que o pai da psicanálise já havia percebido no ser humano a necessidade de alguma coisa que a ciência não pode explicar. Através da poesia, das artes, em geral, e também da psicanálise, encontramos a expressão deste desejo, deste anseio por um espaço místico. Perguntamo-nos anteriormente, de que forma a igreja penetra no território de fantasia do ser humano e se o uso que faz deste território é direcionado para a saúde, enquanto espaço de liberdade e criatividade, ou para reforçar a alienação em seus vários sentidos.

Muitos elementos nos indicam que a resposta para a interrogação que levantamos, caminha no sentido de que o território de fantasia é direcionado, pela IURD, para reforçar a alienação, em seus vários sentidos. Apoiadas no material teórico levantado, iniciando pela psicanálise, encontramos no estudo desses grupos sociais, formados por pessoas desfavorecidas, mas dentro de uma instituição forte e organizada, a compreensão de determinados fenômenos grupais que nos permitiram entender a dinâmica das relações coletivas, onde ocorre um fenômeno que consideramos fundamental para o entendimento destas relações: trata-se do mecanismo de identificação, através do qual pode-se visualizar grande parte do processo e da história dos grupos dentro da IURD.

Diz Freud que o indivíduo, duplamente ligado à massa por laços afetivos, carece de liberdade. Entendemos que a liberdade à qual Freud se refere, é aquela liberdade de que goza o homem em seu território de fantasia. Ao assistirmos aos cultos, pudemos perceber com clareza a total 
falta de iniciativa e autonomia do público fiel. Na observação realizada numa reunião-culto chamada "Corrente da Família", por exemplo, vimos um grupo de mulheres que passa 50 minutos, aproximadamente, repetindo exclusivamente a palavra "Amém". Em outras observações, chama a atenção, o fato das pessoas se manterem limitadas em sua linguagem, ao ponto de ficarem apenas repetindo as frases, palavras e gestos dos pastores. Os movimentos são mecânicos e também repetitivos.

Consideramos que o exercício da iniciativa, autonomia e criatividade, são funções essenciais à realização do ser humano. Isso é impedido nas práticas da IURD e direcionado no sentido de captar e manter fiéis dentro dos limites "territoriais" por ela definidos. De forma geral, em nossas observações, não detectamos nenhum elemento que apontasse participação e crescimento dos fiéis. Por outro lado, a IURD tem demonstrado "prosperidade", palavra usada massivamente pelos pastores quando se preparam para pedir o dízimo. Comparando a estagnação dos fiéis com o desenvolvimento da IURD, verificamos a existência de uma relação assimétrica de poder, o que de acordo com Guareschi (1992), configura a dominação de uma pessoa ou grupo sobre outra pessoa ou grupo.

Os dados colhidos sugerem que a tendência geral das práticas da IURD é penetrar no território de fantasia da pessoa através da persuasão para dominar e explorar seus fiéis em seus conteúdos psicológicos, políticos e econômicos. A persuasão demonstrou ser uma das técnicas de dominação mais usadas pela IURD. A atitude primordial do persuasor é atrair, captar, sugerir e entusiasmar. Estes elementos estão claramente configurados na relação do pastor com seus fiéis nas observações que realizamos.

Destacamos de uma observação, alguns trechos em que a mulher do pastor (MP) fala ao grupo:

(...) Então fale com Deus agora, não perquem (sic) esta oportunidade. Deus te trouxe aqui. Deus te trouxe aqui, por que ele não quer que nenhum mar afogue a tua família (...). Fale comigo: Meu Deus (Meu Deus), eu já sou (eu já sou), uma benção (uma benção). Levante as mãos para o céu. Meu Deus (Meu Deus) eu já sou (eu já sou), e aonde (e aonde) eu colocar meus pés (eu colocar meus pés), o senhor é comigo, (segue em eco). O senhor é com minha família, o senhor é com meus filhos. Em nome de Jesus (3x). E uma salva de palmas para o Espírito-Santo (todo mundo bate palmas). Amém pessoal (Amém!)

Nesse trecho, MP convida as pessoas a falar junto com ela, o que está entre parênteses é o "eco" das mulheres. Este texto foi falado com um tom cada vez mais elevado de voz, até que ao final já estavam gritando. Percebe-se que o líder do culto faz uso desta técnica para manter os fiéis. No exemplo citado acima, fica evidente o entusiasmo provocado por este.

A interação do pastor com o grupo baseia-se fundamentalmente na prioridade dos sentimentos sobre a razão. Dentro desta perspectiva, ele consegue manter um canal de comunicação que de forma direta vem satisfazer às necessidades destas pessoas. O discurso dos líderes da IURD é de apelo sentimental. De todas as observações de campo e dos programas de TV, percebemos que o alvo deles é a família, a solidão, o desemprego e os relacionamentos. Parecem aproveitar-se da susceptibilidade que estes temas oferecem e infiltram-se na intimidade de cada um, provocando um estado de sensibilidade vulnerável, onde o discurso é desprovido de qualquer conteúdo racional, lógico ou coerente. Por exemplo:

(...) Quando Jesus, ele tava naquele barco, (...) ora, levantou-se grande temporal de vento e as ondas se arremataram contra o barco de modo que o mesmo já estava enchendo d'água. Talvez na sua casa deva estar enchendo de "poblema", de olho grande, de inveja, de macumba, de briga, de de vício, de doença, de mal tratos, de solidão.(...) E esta água hoje na tua casa, não precisa ser água de beber (...) água de "poblema", mesmo.

O persuasor é uma pessoa de espírito penetrante e cria a melhor forma de agir. Uma boa tática é o emissor falar de si mesmo e do próprio grupo que escuta, fazendo desta forma surgir o interesse, ou seja, identificação. Na corrente da família, a oradora diz: "quando o meu marido chega em casa, ele gosta de me ver sorridente e bem animada e o de vocês hein, gente? Amém?".

Os pastores são mestres na arte da persuasão e usam com perspicácia o processo de identificação para atingir seus objetivos. A palavra é o instrumento mais utilizado, mas também elementos físicos (voz, gestos, apresentação) citados por Bousquié, são maciçamente utilizados. A entonação de voz dos pastores segue um mesmo padrão, e a plasticidade desta é por demais explorada. Como podemos observar nos dois cultos da 
corrente da família, MP consegue passar do choro ao riso em pequenos intervalos de tempo.

Os gestos são também utilizados, inclusive de maneira teatral, interpretando por exemplo as letras das músicas. Estes são repetidos pelos fiéis, que não criam seus próprios movimentos, apenas reproduzem enquanto cantam. A MP diz para colocarem a mão no coração - música: “eu vim buscar minha felicidade (...) só Jesus me satisfaz (...) eu quero mais do seu poder (...)", depois manda erguerem os braços para segurarem nas mãos de Deus enquanto cantam: “(...) se as águas do mar da vida, quiserem te afogar, segura nas mãos de Deus e vai (...) pois elas, elas te sustentará (...)". Todas as pessoas obedecem as solicitações e colocam a mão no coração e após erguem os braços (inclusive nós).

No que diz respeito à apresentação, seguem o padrão indicado por Bousquié, ou seja, nem muito rebuscado e tão pouco negligente. A simpatia e o carisma são outras armas utilizadas, a postura de bem-estar do pastor e sua descontração atraem e envolvem o público, deixando-o à vontade e livre de tensão, parecendo entorpecido por este ser "iluminado" que lhes fala.

Os pastores têm o desempenho dos animadores de programa de showmen. Desta forma conduzem o culto dando várias ordens ao público como: "de pé gente", digam "Amém", "sentem”, "levantem, caminhem até aqui", "levantem as mãos"; "levantem o saquinho de sal com a mão direita"; "mostrem a mão aberta" etc.

Estas ordens são obedecidas prontamente, sem questionamento e com uma alegria patética. Também é patético o modo como os fiéis são induzidos a pagar o dízimo, depois de aproximadamente 60 minutos de culto, com vários movimentos que vão desde o relaxamento até a exaltação, terminando em catarse coletiva.

Podemos distinguir cinco níveis diferentes da comunicação verbal nos cultos da IURD

— entre os membros do grupo (apenas antes de iniciar e na saída);

- entre o líder e o grupo;

— entre o líder e os obreiros;

— entre os membros do grupo e Deus (solilóquio);
- e em um último nível que se expressa pelo imaginário, que consiste na mediação que o pastor faz entre o grupo e Deus.

A comunicação utilizada pelos pastores ocorre em sentido unidirecional, ou seja, o orador fala e o grupo (receptor) apenas responde aos estímulos dados por este. "Vocês estão felizes aqui gente? Amém pessoal?". Todos respondem: “Amém”"

As respostas limitam-se a "sim" ou "Amém" e as perguntas são direcionadas e induzidas, como por exemplo: "sentiram a presença de Deus?", “Sim", responde o grupo.

Oro (1992) salienta que esta é uma prática comum na IURD, ou seja, a identificação das pessoas que já foram de alguma forma "agraciadas" pela religião, o que, em psicanálise, significa induzir à identificação em grupo. Percebe-se que com esta situação, além da identificação, há um exercício de dominação, pois todas as respostas sutilmente induzi das pelos pastores, reforçam o poder da igreja como instituição divina.

Os discursos dos líderes da IURD são também carregados de sentido ideológico, uma vez que identificam os problemas das pessoas e atribuem sua origem e solução a uma explicação transcendental. Isto vem ao encontro da definição de Enrique Dussel (1980) de religião superestrutural, pois serve aos interesses do poder, sem ter uma postura crítica diante do social, e atribuindo todas as explicações e soluções dos males, aos deuses. É assim que a IURD se comporta. Todas as respostas estão na fé, tanto a cura como a felicidade e até mesmo o dinheiro. Qualquer necessidade espiritual ou material pode ser suprida com a fé e a entrega ao Espírito Santo. Esta mensagem de conformismo e falta de incentivo ao espírito crítico, configura um tipo de dominação, pois mantém seu público resignado à vontade divina.

O discurso dos pastores é também desprovido de lógica. Muitas vezes há dificuldade de entender o significado de determinadas palavras ditas com eloquência, mas o público permanece preso ao discurso do pastor, respondendo a seus clamores com uma subserviência total. Em nenhum dos cinco níveis mencionados se verifica o uso do diálogo. Esse movimento unidirecional na comunicação revela uma relação de dominação subjacente, onde quem detém a comunicação termina por apropriar-se da identidade do grupo. Neste caso, o receptor da mensagem, é desapropriado de sua ego e 
altero-ideologia, e fica exposto à dominação que se dá em nível psicológico e ideológico.

A técnica da persuasão auxilia na compreensão do fenômeno da identificação, talvez o mais importante de todos os que se dão nas relações da IURD com seus fiéis. Já em nossas primeiras observações informais, indagávamo-nos sobre como o processo de identificação, entendido psicanaliticamente era usado como meio de manipulação. Parecia ser difícil demonstrar empiricamente como os pastores se apropriavam de um processo mental espontâneo em nossa vida psíquica, para captar e condicionar fiéis.

Para nossa surpresa, não foi difícil constatar o que Freud, já dizia: "identificação é a manifestação mais precoce de uma ligação afetiva a outra pessoa, desempenha um papel importante na pré-história do complexo de Édipo"(1959:47). Verificamos em nossas observações, que o processo de identificação está sempre e massivamente presente.

Os pastores têm uma capacidade de comunicação, sedução e persuasão que não deixam dúvida quanto às suas qualidades carismáticas. Estas características são comuns aos pastores e são observadas tanto nos cultos, como no programa "O Despertar da Fé", sendo que nos cultos os pastores são mais eloquentes e exuberantes que nos programas de TV. Constata-se que a IURD promove algum tipo de preparação para seus pastores, pois eles agem e atuam de forma idêntica, atingindo com extrema competência seus alvos. Sua capacidade de absorver a atenção do público é tão grande que somos levados a pensar na hipótese de Freud sobre a hipnose. Não basta o conceito de duplo laço afetivo entre o indivíduo e a massa para dar conta da relação dos pastores da IURD e seus fiéis.

Parece evidente que forças mais profundas do que o convencimento puro e simples são invocadas. Se fossemos crentes, poderíamos pensar que são "forças demoníacas". Mas como estudantes de psicologia, procuramos buscar nas contribuições de Freud sobre a hipnose e sugestão, bem como sobre a transferência, uma explicação dessas práticas. Freud descreve o fenômeno da hipnose em sua obra A Psicologia das Massas e Análise do Ego (1959), e afirma que a transferência pode ocorrer fora da psicanálise, não por causa dela e sim pela neurose. Através das observações, verificamos fenômenos que podem ser relacionados com hipnose e transferência nos cultos da IURD. Na "corrente da família", por exemplo obedecendo à ordem da oradora: "falem com Deus agora" as mulheres se concentram e começam a falar com Deus. Inicia-se uma cena impressionante, onde em transe hipnótico falam com Deus ou com Jesus, contando e confessando seus dramas. Algumas murmuram, outras gritam, todas choram. Uma das mulheres se ajoelha no chão e chora com a cabeça debruçada no banco de madeira. A oradora inicia então o retorno do grupo ao estado anterior, usando a mesma técnica: o canto de músicas religiosas. É assim que se iniciam e terminam as sessões de catarse do grupo.

De igual modo o uso da música, conduz à mesma "sintonia". Todos são colocados em um mesmo nível de concentração e relaxamento. Numa ocasião, logo após o canto, a MP, no papel de mediadora de Deus, faz suas pregações e proporciona um espaço para o grupo realizar sua catarse, ficar em estado de alívio e também de vulnerabilidade. Segue-se sempre outra música, que tira o grupo desse estado e o traz a uma nova "sintonia".

Em nossas observações, percebemos que invariavelmente os cultos iniciam com esta técnica grupal de descontração através da música. Em todos os nossos registros se pode verificar o uso de som desde os mais suaves (para relaxamento) até os mais empolgantes (momento da catarse). Com a utilização de música, linguagem verbal e não verbal, o público vai sendo induzido pelo pastor a um estado de hipnose. Como já foi dito, não se observa nenhuma manifestação espontânea ou criativa do público. Apenas verificamos gestos e linguagem repetitiva.

Gostaríamos de retomar ao tema do "território de fantasia". Muitos outros escritores, psicanalistas, músicos e poetas, trazem em suas obras, ideias que nos remetem a este território. Porém, é em Viktor Frankl que vamos encontrar as palavras mais adequadas para conceituar o território de fantasia; quando diz que é importante

acreditar e carregar sempre alguém ou alguma coisa, seja pessoas amadas, uma obra, um sentimento religioso ou uma perspectiva de futuro para se vencer dificuldades, fome, humilhações, injustiças ou outro obstáculo que a vida pode apresentar (1987:9).

Diz ainda que acredita na capacidade humana de transcendência em um momento difícil e a partir daí descobrir uma adequada verdade orientadora (1987:10). São precisamente tais capacidades, ao nosso ver, que 
parecem faltar aos fiéis da IURD. Paradoxalmente, lhes é oferecido como um objeto de consumo, um mundo interior que está sendo roubado.

Para Frankl, "a liberdade interior do ser humano, a qual não se lhe pode tirar, permite-lhe até o último suspiro configurar a sua vida de modo que tenha sentido"(1987: 85). Constatamos situações em que a liberdade interior, de que fala Frankl, infelizmente pode ser retirada de uma pessoa. Quando existe uma relação de dominação econômica, ainda pode restar ao dominado, uma consciência que lhe permita compreender sua condição e agir sobre ela a fim de transformá-la. Mas quando falamos de dominação psicológica, falamos de desapropriação do "território de fantasia". Neste caso, a consciência está alienada de tal forma que sonhar passa a ser um ato subversivo Nas práticas da IURD, o que sonha é alguém com "espírito maligno", que deve e precisa ser exorcizado. Frankl afirma que a vida só tem sentido se conseguimos transformar criativamente os aspectos negativos em algo positivo. Transformar e criar são palavras chave da saúde mental humana. Para ele, a busca de sentido da vida deve ser uma ação livre e baseada em motivos internos, não externos; a esperança,. o amor e a fé não podem ser impostos ou exigidos.

É impressionante observar a forma como os elementos acima referidos são utilizados pela IURD, para reforçar a dependência dos fiéis à igreja. A IURD surge no Brasil exatamente em 1977, ironicamente no "Bairro da Abolição", no Rio de Janeiro, em plena ditadura militar. O pensamento político sufocado, reprimido e torturado. A classe operária, bem longe do "paraíso". A educação em franca decadência. Infelizmente, muito pouco se alterou neste cenário, e realmente só "prosperaram" desde então, aqueles que de alguma forma se beneficiaram com a situação do país. Foi neste contexto, que a IURD cresceu e proliferou enormemente. É difícil compreender como uma instituição que se diz a serviço do povo, em nome de "Jesus", pode ir tão bem quando seus fiéis vão tão mal.

Guareschi afirma que "quando um grupo, religioso não causa incômodo à um regime dominador, é provável que esteja servindo a este regime"'(1989: 86). É a impressão que temos da prática exercida por essa igreja. Enquanto os fiéis ficam na IURD realizando intermináveis rituais para resolver seus problemas, suas vidas permanecem estagnadas, paralisadas social, psicológica e politicamente, deixando adormecido o poder de transformação, que cada ser humano guarda em seu "território de fantasia". A IURD ensina seus fiéis a buscar no além o que eles encontrariam na busca da cidadania.

Podemos ainda perguntar: que benefícios a IURD traz a seu fiéis? A partir das nossas observações e estudos de materiais já existentes sobre a IURD, constatamos que os benefícios prestados por esta instituição são principalmente de cura de doenças (dor de estômago, cefaleia, câncer, AIDS), alcoolismo, homossexualismo, conduta antissocial e o exorcismo. Os depoimentos de curas que constam nos livros do "bispo" Edir Macedo são, no mínimo suspeitos, e os prestados no programa "O Despertar da Fé" não merecem confiança, pois pode-se duvidar da sinceridade dos mesmos. As situações em que um fiel oferece o dízimo em proporção ao que deseja receber de Jesus, ou Deus, ocorrem com muita frequência em função de um forte apelo da IURD. Nos programas de TV, temos vários exemplos de "testemunhas" contando as graças recebidas após terem "ofertado o dizimo". Segundo Oro (1992), a principal motivação para a doação financeira é a ideia de que o dinheiro é o bem mais significativo para selar uma aliança com Deus. E partindo do pressuposto de que nada é de graça, no mundo sobrenatural não seria diferente, a oferta força a divindade a atender sua demanda.

Gostaríamos de discutir, finalmente, uma questão levantada ao início de nossa pesquisa: que tipo de imagem a IURD passa de Deus? Simbólica ou concreta? Incentivadora ou cerceadora? Encontramos em Freud (1959) a hipótese do poderoso macho, líder absolutista, um pai primitivo que não permitia a satisfação sexual dos filhos, exigindo destes abstinência e submissão. Os filhos, por sua vez, temiam e idealizavam o pai (Freud, 1959, p.34). Ferenczi (in Freud, 1959, p.74) demonstra a submissão do hipnotizado em relação ao hipnotizador, representante do pai primitivo onipotente, relação que só permite ao hipnotizado colocar-se em atitude passiva masoquista. É em situações semelhantes que encontramos o público da IURD. A passividade e o conformismo patéticos podem ser entendidos por nós como uma postura masoquista dos fiéis em relação ao sadismo disfarçado de religiosidade dos pastores.

Como já dissemos, não registramos em nenhuma de nossas observações, qualquer atitude que indicasse iniciativa, criatividade e espontaneidade dos fiéis. Com base nestes dados entendemos que a imagem de Deus, transmitida aos fiéis da IURD, é uma imagem concreta, totêmica e 
cerceadora. O material gráfico coletado é um bom exemplo desta imagem, pois estabelece uma hierarquia entre Deus e as pessoas. Nesta hierarquia temos então um primeiro nível, Deus, abaixo dele o marido, depois a mulher e por último os filhos. A comunicação se estabelece nesta ordem linear e rígida. Deus só se comunica, na verdade com o homem, e a mulher poderá falar com Deus através deste.

Esta situação é bastante contraditória pois acontece exatamente na "corrente da família", que é conduzida pela mulher do pastor. Ela diz ao grupo de mulheres: "agora podem falar com Deus, ele já está te ouvindo". No caso, ela anunciava que a "ligação direta para Deus" havia se completando através de sua própria pessoa. Esta é apenas uma amostra da comunicação baseada na dupla mensagem, que a IURD estabelece com os fiéis.

Poder-se-ia finalmente perguntar por que as crianças não têm ascendência na comunicação com Deus? Seria porque as crianças não produzem, não ganham salários e não pagam o dízimo? Os dados parecem sugerir uma resposta positiva.

\section{Considerações finais}

Foi com muita dedicação, prazer e algum sofrimento, que realizamos este trabalho. Desta pequena, mas importante experiência, chegamos a algumas conclusões, que julgamos relativamente justificadas:

É função também do psicólogo procurar entender o fenômeno religioso, uma vez que se chega a compreender que a religiosidade é uma necessidade psicológica do ser humano. Não é mais possível, como já pensava Freud, fazer "vistas grossas" a isto, agarrando-se a um ceticismo estéril, enquanto a sociedade cada vez mais absorve este produto. Parecenos que a questão da relação IURD/fiéis, deve ser analisada e trabalhada no campo da psicologia social.

Fica evidente a necessidade humana de um espaço mental livre da objetividade. Esta imperiosa demanda se expressa de inúmeras formas, seja através da arte, da criatividade, do misticismo, religiosidade, etc. Denominamos a isso "território de fantasia".

Parece que a forma como é usado este território tem estreita relação com a condição social da pessoa. Assim, o consumismo pode preencher esse espaço. Em populações pobres e exploradas, o "território de fantasia" pode ser apropriado e usado pela alienação, exploração e dominação.

Historicamente, a classe menos favorecida, constituída em sua maioria por trabalhadores informais e operários, tem buscado conforto nas religiões não católicas como espiritismo e religiões afro-brasileiras.

A Igreja Católica tradicional, enquanto aparelho ideológico de estado, cumpriu seu papel permanecendo fiel as estratificações sociais, não questionando o modo de produção, nem a ausência da classe operária em suas igrejas. Esta, por sua vez, ansiosa por dar vazão a sua subjetividade e preencher seu território de fantasia com algum alimento emocional, já que muito pouco lhe resta a almejar na área do capital, foi em busca de alguma instituição. As Igrejas Neopentecostais, especialmente a IURD, se organizaram e estão aí. Captaram perfeitamente este anseio e carência social, oferecendo para aquela faixa da população um bem de consumo espiritual alienante. Dentro desta lógica, é fácil entender a proliferação destas igrejas.

O que se questiona e se pretende alertar, é a forma como esta relação está se dando. O território de fantasia está sendo ilegitimamente "ocupado" pela IURD, com a finalidade de dominar e explorar seus fiéis. Conclui-se que, de modo geral, a IURD é uma instituição ideológica que tem por objetivo dominar através da persuasão, para explorar economicamente seus fiéis. A dominação se dá através da invasão e apropriação do território de fantasia. A postura até certo ponto paranoide, institucionalizada na IURD, refletiu-se em vários momentos de nosso trabalho, confirmando nossa hipótese inicial de que aquela instituição legitima relações de dominação e exploração com seus fiéis.

Dar conta de nossa proposta inicial foi um trabalho bastante pesado, mas a cada linha escrita, outra ia brotando, florescendo pensamentos. $\mathrm{Na}$ verdade pesquisamos muito mais do que a ideologia de uma religião: pesquisamos nosso próprio "território de fantasia", de onde certamente garimpamos as ideias que resultaram neste trabalho. Afinal, aprendemos mais do que nunca que sonhar é preciso e que a utopia é o primeiro passo no caminho da liberdade, passaporte do território de fantasia. 


\section{Referências bibliográficas}

BOUSQUIÉ, Georges (1961). Psicologia practica de la persuasión. Barcelona: Hispano Europea.

CORN, Gabriel (1973). Sociologia da Comunicação. São Paulo: Pioneira.

DUSSEL, Enrique (1980). Religión. México: Edicol.

FRANKL, Viktor (1987). Em busca de sentido: um psicólogo no campo de concentração. Porto Alegre: Sulina.

FREUD, Sigmund. (1959). "A Psicologia das Massas e Análise do Ego". In: Obras Completas. Rio de Janeiro: Delta, vol. VI.

GUARESCHI, Pedrinho A. (1985) A cruz e o poder. Petrópolis: Vozes.

(1991) Sociologia Crítica: alternativas de mudança. 37 ed. Porto Alegre: Mundo Jovem.

. (1992) Sociologia da Prática Social. Petrópolis: Vozes.

JAQUES, Elliot "La Defensa Contra La Ansiedad in KIEIN, Melanie et alii, Temas De Psicanálise Aplicada. Rio de Janeiro: Zahar.

JUNG, Carl G. (1984) "Psicologia e Religião" in: Obras Completas. vol. XI. Petrópolis: Vozes.

LAPLANCHE, Jean. (1992) Vocabulário da Psicanálise / Laplanche e Pontalis. São Paulo: Martins Fontes.

SCLIAR, Moacir (1991) "O Apelo do Oculto". Wonderfull, III, n. 15, pg. 19-22.

THOMPSON, John B. (1990) Ideology and Modern Culture, Cambridge: Polity Press.

ZIMERMAN, David. (1993) Fundamentos Básicos dos Grupoterapias. Porto Alegre: Artes Médicas.

\section{Apontamentos para uma análise institucional da universidade}

Paulo Roberto de Carvalho Universidade Estadual de Londrina

Dedico este texto a todos os colegas de trabalho que voluntária ou involuntariamente contribuíram para sua realização.

A ascensão da produção e prática na área da Análise Institucional, tal como acontece hoje, coloca-nos a permanente necessidade de retomar, a cada vez que aí retomarmos, as práticas e campos teóricos compreendidos por esta área. Retomada necessariamente parcial, que a cada vez que ocorre acrescenta uma perspectiva, um novo ângulo de abordagem no conjunto daqueles já anteriormente colocados.

Talvez fosse útil, num primeiro momento, assinalar os objetos da produção teórica e prática da Análise Institucional, aquilo que se pretende apreender no contexto institucional, bem como aquilo que se pretende aí transformar: as relações de poder (RODRIGUEZ E SOUZA ${ }^{1}$ ) contribuem, neste sentido, ao localizarem o objeto da atenção na análise institucional: "A análise institucional tem um conteúdo quase exclusivamente POLÍTICO". Aqui talvez coubesse um questionamento sobre as relações entre a Análise Institucional e a psicologia: como um procedimento que objetiva a apreensão das implicações políticas (relações de poder) colocadas num contexto institucional pode ser amplamente aceito pelos profissionais da psicologia? E as especificidades de tal ciência, como ficam? Sem pretender aqui aprofundar um debate que atravessa a psicologia, podemos assinalar que a concepção de subjetividade proposta por Deleuze e Guattari resgata justamente a noção de "campo de forças" para uma compreensão dos processos psíquicos. A relação entre as diversas forças, ou impulsos vitais, toda uma multiplicidade de desejos e vontades, que ora se aliam, ora se enfrentam mutuamente já é, ela própria, política. O resultado deste processo micropolítico, infraindividual, é a ocorrência sempre precária de uma nova configuração de forças, um novo estado subjetivo (por vezes consciente) e assim sucessivamente. Desaparecem desta forma as distinções

${ }^{1}$ RODRIGUEZ, H.B.C., e SOUZA, V.L.B., in Análise Institucional no Brasil. Kamkhagi, V.R. et all (org.), Editora Rosa dos Tempos, 1991. 
entre o psicólogo e o político. A subjetividade já é, nesta concepção imanentemente política, o que possibilita a proximidade de uma vertente da psicologia com a Análise Institucional. A problemática política, colocada pela Análise Institucional resgata de modo unificado a objetividade e a subjetividade implicadas nas relações de poder e pode, portanto ser retomada pela Psicologia Social, como alternativa de intervenção.

Entre aqueles que se destacam na produção teórica sobre as instituições, Michel Foucault foi um dos que mais incisivamente apontou para as relações de poder, a ponto de definir a própria posição do intelectual contemporâneo como comprometido com a transformação neste campo. Ao intelectual cabe levantar a diante a "Luta contra o poder, luta para fazê-lo aparecer e feri-lo onde ele é mais invisível e mais insidioso". ${ }^{2}$ Como, no entanto, realizar tal projeto? Como iniciar o enfrentamento, nos diversos contextos institucionais localizados? O que seria previamente necessário, para tanto? O autor nos coloca que "seria necessário saber até onde se exerce o poder, através de que revezamentos e até que instâncias, frequentemente ínfimas, de controle, de vigilância, de proibições, de coerções. Onde há poder, ele se exerce". Tais colocações refletem, entre instituições que se superpõem em nosso cotidiano. Isto não impede, no entanto, que Foucault, aponte alguns campos estrategicamente privilegiados para a subversão das relações de poder. Assim, cabe ao intelectual contemporâneo promover o enfrentamento lá onde "ele (o poder) é, ao mesmo tempo, o objeto e o instrumento: na ordem do saber, da 'verdade', da 'consciência', do 'discurso"'. ${ }^{4}$ Esta observação é particularmente significativa para os propósitos deste texto, por apontar elementos para uma análise da instituição universitária. A ordem do saber e da verdade seguramente aí se encontram.

No entanto, o questionamento ainda uma vez mais se coloca: como atacar as formações de um saber-poder na Universidade? Como conduzir a luta para fazê-lo (o poder) aparecer? Aonde poderíamos encontrar os signos da visibilidade do poder, aos quais o próprio Foucault se reportou? Sem dúvida, seriam muitas as respostas possíveis. Optamos aqui por uma análise de dois fragmentos do discurso usualmente utilizado no meio

\footnotetext{
${ }^{2}$ FOUCAULT, M. — Microfísica do Poder. Editora Graal, 1984. 4 a Ed., São Paulo, p. 71.

${ }^{3}$ Idem, p. 75.
}

${ }^{4}$ Idem, p. 71 universitário. O nosso interesse sobre estas duas expressões decorre do fato de que elas designam justamente posições de poder formal e informalmente atribuídos no meio ambiente universitário. Elas são parte daquilo que $(\text { GOFFMAN })^{5}$ qualificou como "gíria institucional", um discurso codificado segundo as especificidades do contexto no qual ele é produzido. Há porém uma dúvida: poderia a Universidade ser analisada, neste aspecto, a partir de uma referência a um texto que se dedica exclusivamente às instituições totais ou fechadas? A resposta é no mínimo incômoda e incide diretamente sobre a problemática das relações de poder na Universidade, que buscamos analisar. É o próprio Goffman que conclui sua análise das instituições totais se referindo à Universidade, sugerindo assim uma possível aproximação. Possivelmente, porém, a gíria Institucional adquire, no caso da Universidade, características próprias. Vamos, de qualquer forma, às referidas expressões, que aqui apresentamos como um signo das relações de poder cristalizadas no cotidiano da Universidade. São expressões bastante conhecidas e utilizadas em diversas universidades, geralmente associadas ao professor universitário, mas eventualmente também ao candidato à professor. São elas a cobra-criada e a cria. Esta última é muitas vezes também identificada através da expressão "peixinho".

\section{A "cobra criada" e sua" cria"}

O prosseguimento de nossa análise requer uma exposição dos conteúdos cotidianamente associados a cada uma destas personagens nas mais diversas universidades brasileiras. A cobra-criada é quase um professor com muitos anos de trabalho na instituição. A expressão cobra, ao que parece, se reporta ao caráter agressivo, perigoso, normalmente atribuído ao réptil. Já a expressão criada parece indicar que a cobra em questão já é bem desenvolvida, sugerindo uma relação de boa adaptação ao meio. Conhecida de todos, a cobra-criada tem como prática política mais evidente a demarcação de um território no interior da instituição, enquanto área de sua influência, onde incidem as determinações de poder que ela pessoalmente encarna. É importante observar que tal poder é de natureza mista. Trata-se de uma composição que incorpora um aspecto formal, marcado pelas honrarias e distinções recebidas, bem como pelos cargos ocupados na hierarquia institucional e um outro aspecto informal, marcado

${ }^{5}$ GOFFMAN, E. Manicômios, Prisões e Conventos. Editora Perspectiva, 1986, p. 51. 
pelo medo que a personagem inspira aos demais, ao se fazer presente, enquanto cobra-criada no imaginário institucional. DE BRASI, ${ }^{6}$ ao sistematizar a questão da violência nas relações sociais e institucionais, assinala justamente a criação de território, que ele qualifica de "sagrado" no interior das instituições de produção do conhecimento. As práticas pelas quais o território se instaura, bem como aquelas executadas no seu interior serão agora o objeto de nossa atenção. Entendemos que tais práticas são fundadas na heteronomia, na relação autoritária, e fundantes desta. São resultantes de um saber-poder, que no contexto do território delimitado aparece como sendo a verdade científica. Toda e qualquer proposição ou concepção que escapar ao saber oficial, aquele adotado pela cobra-criada, está destinado a ser desqualificado e a ser banido do território delimitado. De Brasi ressalta que no interior do território as questões colocadas a partir da dita "verdade científica" implicam "antes de tudo formas de impor o que pode ser aceito, incluído, como critério de cientificidade por excelência e o que se deve proibir ou excluir por falta desta prerrogativa". ${ }^{7} \mathrm{E}$, com base proibir ou excluir por falta desta prerrogativa". E, com base nesta prática, a discriminação arbitrária sobre as vertentes do conhecimento em uma determinada área é sistematicamente realizada. Práticas, que no entender de De Brasi, implicam em considerável dose de violência. E "é sobre a marca de tal violência que se instala e aceita como normal o terrorismo epistemológico". 8 É ele o "terrorismo epistemológico", a expressão mais direta, mais sistemática e visível do saber-poder. Toda a prática do terrorismo se organiza em função da exclusão, seja de um modo de saber, articulado em um discurso, seja do portador do mesmo.

O autor resgata, no entanto, que semelhantes práticas só são possíveis à medida que estão inscritas e mesmo legitimadas pelo contexto institucional, particularmente pelas suas estratificações hierárquicas. "Prestígio, ascensões bruscas ou graduais, progresso econômico, etc. (...) indicam como certos sujeitos tem sido "'emplumados', carregados com distintivos cujo objetivo é distinguir umas pessoas das outras dentro do meio igualitário". " Assim é que a ritualização do saber, ao resultar na

${ }^{6}$ DE BRASI, J.C. in Lo Grupal, $\mathrm{n}^{\circ} 3$ - Pavlovski, E. (org.) - Ediciones Busqueda, Buenos Aires, $1^{\text {a }}$ Ed. 1986, p. 50

${ }^{7}$ Idem, p. 50

${ }^{8}$ Idem, p. 50

${ }^{9}$ Idem, p. 51 hierarquia institucional, torna-se tributária do terrorismo epistemológico. Passemos agora à uma análise dos aspectos mais informais do exercício de um poder-saber.

Situamos ao plano informalidade por exemplo os comentários e conversas que acontecem no cotidiano institucional, um dos campos de atuação da cobra-criada. De Brasi, resgata a ocorrência dos rumores na instituição como parte dos procedimentos de exclusão que aí se instalam. "A informalidade de um rumor ou extrapolação deformante, não por sua ligeireza escapam à efetividade, que buscam produzir. (...) Então, essas formações cumprem basicamente o fim de solidificar um papel específico, controlar o acesso institucional de certos elementos relativamente independentes, de manejar os possíveis desviados do sacralizado" . Assim a exclusão ou então o controle sistemático daquele que diverge, de forma a neutralizá-lo, eis as possibilidades de atuação colocadas para a cobracriada. De qualquer forma, finaliza o autor, trata-se de "uma poderosa pressão à conformidade" $" 11$ que aqui se revela.

Exploremos agora segunda personagem, presente nos fatos cotidianos das mais diversas instituições, mas sem dúvida muito frequente na Universidade, a cria. Esta, como dissemos, por vezes é chamada de peixinho. Novamente somos levados a um ingresso momentâneo no discurso do cotidiano universitário. Este nos apresenta a cria como sendo o candidato à ocupação de um cargo, no mais das vezes de professor, e que usa como estratégia para conseguir o ingresso no quadro institucional justamente a relação que mantém com as cobras-criadas de um determinado segmento. Esta relação pessoal com os detentores do saberpoder se reveste então de implicações políticas.

Em contrapartida à sua aceitação, a cria vai oferecer uma série de provas de submissão, servilismo e lealdade, bem como uma adesão incondicional à quaisquer posições ou práticas adotadas pela sua protetora, a cobra-criada em questão. Personagem muito conhecida, ainda que pouco estudada, as crias fazem parte do cotidiano institucional no Brasil e, ao que parece, também em outros países. Goffman, por exemplo, no texto já citado, se aproxima bastante deste tipo de relação estabelecida nas

\section{${ }^{10}$ Idem, p. 53}

${ }^{11}$ Idem, p. 54 
instituições universitárias onde, segundo ele, "encontramos o sistema dos 'velhos amigos' nas escolas particulares e universidades, que funcionam como comunidades optativas para a distribuição de oportunidades". ${ }^{12}$ Seja na fala de Goffman, seja na relação estabelecida entre a cobra-criada e sua cria, encontramos a prevalência do privado sobre o público. Na situação específica dos procedimentos de seleção para o cargo de professor podemos assinalar que o público está representado pela própria organização do concurso (aberto a todos) que foi, no entanto, sobredeterminada pela relação privada.

Tal como vimos, De Brasi, ao analisar as honrarias, láureas e distinções no contexto institucional, resgata sua importância para a negação do "mito igualitário", a ideia de que perante a estrutura da instituição somos todos iguais, portadores dos mesmos direitos e prerrogativas. Qual é a posição da cria, quando vista sob o ângulo do "mito igualitário" institucional? Como sua admissão se deu sob o égide do privado e em condições de uma heteronomia explícita, o "mito igualitário" ocupa a posição inexistente, não apenas como mito, mas fundamentalmente como qualquer forma de relação que se aproxime do igualitário. À cria só resta reproduzir ad infinitum as condições heterônomas que lhe deram origem. Ela carece, ontologicamente de outro que seja sua cria confirmando-a, agora, como cobra-criada.

A cobra-criada e sua cria, enfim, aparecem como posições complementares de uma estrutura que se perpetua na heteronomia. São ambas elementos da já assinalada pressão à conformidade, e consequentemente atuam no sentido da exclusão das diferenças.

A prática adotada por ambas as personagens, por vezes conjuntamente, diante dos desviantes é reveladora. Entre outros, podemos assinalar aqui, a título de sugestão para futuras investigações, o procedimento da exclusão informal do desviante. Suas palavras e atos são sistematicamente esvaziados da significação num determinado contexto localizado. Ele não é tomado em consideração. Esta neutralização tem objetivos táticos bem delimitados de criar condições para que o sujeito tido como desviante introjete a exclusão que lhe é dirigida, subjetivando-se como excluído e por vezes excluindo-se, de forma aparentemente voluntária da instituição.

A leitura que aqui propusemos sobre as relações de poder na Universidade traz consigo uma certa propriedade. Tomemo-la pelo que ela é de fato: um conjunto de apontamentos, o que, num sentido rigoroso implica na explicitação de certos objetos a serem analisados, bem como na afirmação de uma determinada perspectiva, singular e parcial, de abordagem destas questões. Toda e qualquer conclusão sobre o caráter verdadeiro do que aqui foi colocado, fica desde já em suspenso, dada nossa definição do que é um apontamento. 


\section{Uma abordagem estratégica no planejamento de grupos: o Método Altadir de Planejamento Popular — MAPP}

Jáckson De Toni Guilene Salerno Lúcia Bertini

\section{Introdução}

É comum observar-se em diversos grupos organizados da Sociedade Civil (sindicatos, partidos, associações profissionais, etc.) e também em âmbito estatal, a quase permanente frustração em relação ao cumprimento de seus objetivos; as metas traçadas pelo próprio grupo quase sempre não são atingidas na sua integralidade. Das atividades mais simples até as mais complexas, há um predomínio generalizado da improvisação, as práticas de planejamento e gestão interna das organizações sociais deixam-se conduzir pelos acontecimentos do dia-a-dia e os resultados nem sempre são os esperados.

Isto acontece principalmente porque os métodos de planejamento possuem baixa eficiência (desperdício de recursos) e baixa eficácia (não atingem os resultados); além disso a forma tradicional de planejar e conduzir organizações é quase sempre dirigida pela visão normativa, linear e mecânica de analisar a realidade e como consequência na direção dos próprios grupos.

Para tentar corrigir estas deficiências propõe-se um método alternativo de planejamento estratégico conhecido como "Método Altadir de Planejamento Popular" (MAPP). Este enfoque metodológico foi constituído a partir das reflexões originais do ex-ministro do Governo Allende, o Econ. chileno Carlos Matus, no decorrer dos anos setenta e oitenta. ${ }^{1}$ O MAPP tem sido utilizado no contexto brasileiro principalmente nos sindicatos de trabalhadores e entidades dos movimentos sociais populares e vem se constituindo uma importante ferramenta para a

${ }^{1}$ Matus dirige atualmente uma fundação na Venezuela denominada Fundação Altadir (de Alta Direção) de onde deriva o nome do método. O MAPP é uma "versão simplificada" do método PES (Planejamento Estratégico e Situacional), como é conhecido no Brasil, destinado originalmente ao trabalho com grupos populares. organização de grupos, melhoria dos níveis de gestão interna das organizações e clarificação do seu Projeto Político de mais longo prazo.

Nas próximas páginas serão desenvolvidas as principais características deste método dentro do espaço disponível e a natureza deste trabalho.

\section{A crítica ao planejamento normativo}

A tradição de planejamento é uma tradição normativa, isto é, determinística, atua-se sobre a realidade linearmente, sem conceber a existência de outros Atores Sociais ${ }^{2}$ ou da multiplicidade de recursos disponíveis e necessários para execução das ações planejadas. O enfoque normativo de planejamento, fortemente enraizado na cultura estatal, pode ser caracterizado pelos seguintes pressupostos (Rivera, 1992):

1) a planificação supõe um objeto e um sujeito independentes, o sujeito está colocado fora e acima da realidade, que é um sistema incontrolável;

2) a planificação procura conhecer a realidade através do "diagnóstico", orienta-se pela busca da "verdade objetiva", "científica", só há uma "verdadeira explicação" para fatos e acontecimentos, um único diagnóstico;

3) a realidade apresenta comportamentos sociais estáveis e previsíveis, passíveis de serem estudados através de modelos analíticos ou de causalidade das ciências naturais (existe uma "realidade objetiva");

4) como a realidade é "objetiva", a única normatividade possível é a econômica, o elemento político é um dado exógeno ou, no máximo, uma mera restrição;

5) o Planejamento Normativo trabalha com a noção de sistema com final fechado, só há uma chegada e uma única possível trajetória.

O Planejamento Estratégico (MAPP) faz uma crítica radical a estes pressupostos, afirmando exatamente o oposto:

\footnotetext{
${ }^{2}$ Os requisitos para considerar-se um "Ator Social" são: ter organização estável, ter um Projeto Político próprio, ter capacidade de acumular ou desacumular força e ter participação no "jogo social" no qual insere-se o Ator que Planeja.
} 
1) o sujeito (ator social) está dentro do objeto e existe "o outro" que participa com ele do sistema, há uma relação entre atores sociais;

2) toda explicação é dita por alguém a partir de uma situação específica, há mais de uma explicação verdadeira sobre a mesma realidade, não há uma "verdade objetiva". Um explicação situacional é a apreciação de uma situação estando-se consciente da explicação dos outros atores;

3) explicar (ao invés do diagnóstico normativo) implica em compreender como os outros atores sociais criam suas possibilidades num sistema criativo (a vida social). Nem sempre há leis para descobrir, a capacidade de prever é limitada pelo universo de variáveis conhecidas, há a necessidade de trabalhar com cenários;

4) o poder é sempre um recurso escasso porque os outros atores sociais também o possuem e o utilizam. Esta utilização pelos outros estabelece limites à viabilidade do "dever ser" de um ator;

5) o Plano é fundamentalmente um "sistema de apostas" bem fundamentadas, combinando apostas difusas com grande incerteza, o final é sempre aberto, é um sistema probabilístico e não determinista;

6) a normatividade econômica não é a única, a viabilidade política passa a ser um elemento endógeno ao Plano e à sua execução.

Para utilizar o enfoque estratégico de Planejamento é necessário, portanto, reconhecer a existência de outros atores sociais de modo que a eficácia do meu plano depende da eficácia do plano dos demais atores. $\mathrm{O}$ planejamento de organizações sociais sempre é um planejamento de Sistemas Complexos, ou seja, é preciso lidar com forte incerteza, com a diversidade de recursos, com as surpresas e o desconhecido. O MAPP pressupõe a análise da realidade social como um jogo criativo, dinâmico e de final aberto.

\section{Os momentos do MAPP}

Antes de ser um método pronto e acabado o MAPP deve ser visto muito mais como um "enfoque metodológico" a ser adaptado em cada organização, cada "jogo social" determinado. Os "momentos" deste enfoque não são "etapas" independentes, mas fazem parte de um processo constante de permanente aprendizagem, cálculo e recálculo diante da incerteza, eles podem se repetir incessantemente no processo de planejamento mudando de contexto e lugar no tempo. São quatro os momentos do MAPP: 1) Momento Explicativo ("a hora da verdade"); 2) Momento Normativo ("a hora do desejo"); 3) Momento Estratégico ("a hora do poder") e 4) Momento Tático-Operacional ("a hora de fazer"). Serão abordados a seguir.

1) Momento Explicativo: equivale ao "diagnóstico" do enfoque normativo-tradicional. Parte-se da compreensão de que um Ator Social possui "problemas" e é a partir deles que deve explicar situacionalmente a realidade. Deve-se montar um "fluxograma" onde o(s) problema(s) selecionado(s) é (são) decomposto(s) em suas causas, descritores e consequências para o Ator Social que o está explicando, segundo seus valores, objetivos e conduta. As causas dos problemas podem ser decompostas em toda sua complexidade, constituindo elas mesmas subproblemas. Explicar significa, neste caso, manifestar uma intencionalidade concreta, "explico para mudar as causas". A identificação das causas é essencial, pois não atua-se sobre as consequências ou descritores (sintomas) de um problema. O principal produto deste momento é o que denomina-se "Árvore do Problema" onde todos podem visualizar (em tarjetas ou cartelas) toda a rede causal que envolve determinado problema e quais são aquelas causas fundamentais sobre as quais será fundamentada a vontade de mudança, as operações e ações do Plano. Estas causas fundamentais do problema são denominadas de "Nós Críticos". Há duas diferenças com relação ao enfoque normativo do "diagnóstico" tradicional: evita-se o costume de simplesmente descrever e listar problemas confundindo causas, consequências e sintomas; a outra, é a continuidade do momento explicativo que não cessa nunca (é situacional), já que a realidade, os atores e os próprios planos estão sempre em mutação no "jogo social". Neste momento o Ator define também uma Situaçãoobjetivo, onde quer chegar situacionalmente, lembrando que na vida concreta de fato não "resolvemos" problemas, apenas os intercambiamos por problemas menores e menos complexos. A Situação-objetivo é o inverso da situação-inicial, isto é, ao invés da Árvore do Problema, construímos uma Árvore de Resultados, onde, a partir dos objetivos centrais (problema visto como solução), define-se a rede de objetivos 
complementares necessários para atingi-lo (as causas vistas como objetivos/soluções parciais em relação ao problema).

2) Momento Normativo: é o desenho do "dever ser" do Plano. Este é o aspecto principal do Planejamento tradicional, agora ele passa a ser apenas mais um momento no enfoque estratégico. Enquanto o Momento Explicativo é o momento do "foi", do "é" e do "tende a ser", este momento é o do "deve ser", isto é, da manifestação da intencionalidade do Ator Social, de sua vontade de mudar as coisas, atuando sobre a raiz dos seus problemas (os "Nós Críticos"). Quando se desenha as Operações para enfrentar e "desatar" os Nós Críticos, deve-se interrogar sobre a eficácia direcional do que está se fazendo. Isto implica em desenhar Operações com poucos recursos (políticos, econômicos, cognitivos, humanos, etc.), considerar o produto e o resultado de cada operação, detalhá-la em ações coerentes e compatíveis, analisar a eficiência (relação entre Recursos e Produto) e a eficácia (relação entre Produto e Resultado) de cada operação. Desenhar estrategicamente requer um "cálculo interativo" que concebe o resultado dos processos sociais como produto do conflito entre os diversos planos, requer uma apreciação situacional. Esta apreciação pode ser entendida como um "texto" explicativo situado num "contexto"explícito que completa seu significado. Os diversos atores sociais escolhem seus planos, mas não as condições nas quais são feitos e executados, dai a importância de trabalhar com diversos cenários e submeter o conjunto das operações a cada um deles readequando sua eficiência e eficácia, analisando o comportamento dos outros (técnica de jogos, simulações), e enumerando possíveis surpresas (nem todas podem ser imaginadas). O Programa Direcional (conjunto de Operações) "deve" conduzir (não deterministicamente) à Situação-Objetivo definida pela grupo, para isso, deve-se ainda hierarquizar as Operações, analisar seus múltiplos impactos no Problema (a realidade sempre é multidimensional), verificar sua vulnerabilidade (os pressupostos 'de cada uma), considerar as limitações de tempo, recursos, etc.

3) Momento Estratégico: é o momento do "pode ser", do "dever ser". É o momento onde deve-se construir viabilidade estratégica para a execução do Programa Direcional, é o momento do poder, de analisar a possível reação de cada Ator social diante do nosso plano, prever estratégias de cooperação, cooptação, conflito, negociação ou confronto. Para isso é necessário identificar quais são os reais interesses dos demais atores sociais (grupos, organizações, etc.) em nosso problema para identificar possíveis aliados, oponentes e aqueles que são indiferentes. Para cada um serão necessárias estratégias diferenciadas. A estratégia é sempre uma questão de Poder, de acúmulo de forças para impedir ou diminuir a força dos oponentes ao meu Plano. Neste momento deve-se responder a quatro questões básicas: Com quem? (política de alianças), Para quê? (quais operações e que resultados devem ser obtidos com a estratégia), Como? (quais combinações de estratégias serão adotadas: autoridade, negociação, confrontação...) e Com que possibilidade de êxito? (analisar os riscos envolvidos em cada opção e balancear as trajetórias de menor perda).

4) Momento Tático-Operacional: é o momento do "fazer", onde tudo se decide, pois o Plano só se completa na ação concreta. É o momento onde duas poderosas forças se encontram: de um lado a força "dos fatos", a "correnteza" do dia-a-dia, as urgências, o reino da improvisação; do outro lado, o cálculo interativo que precede e preside a ação, o planejamento consciente, a apreciação situacional. É neste embate criativo e dinâmico que são gerados os fatos sociais (intrinsecamente políticos). Enquanto os momentos anteriores constituem análises, desenhos e simulações que não perturbam a realidade, este momento incide diretamente sobre ela como parte dela mesma. Distinguem-se agora várias tarefas: apreciação da situação conjuntural: avaliar a realidade, a direção do planejamento, fatos e processos novos; pré-avaliação das decisões possíveis: confrontar o desenho das operações e ações e verificar quais são, naquele momento, mais eficazes; tomada de decisões e execução: através de meios de gestão e direção organizacional apropriadas, de critérios econômicos e políticos, executar o planejado de acordo com cada cenário analisado e pós-avaliação das decisões tomadas: é a comparação entre os efeitos esperados e os realizados sobre o Problema e em relação à Situação-Objetivo. Estas tarefas estão permanentemente se retroalimentando, isto é, juntas constituem uma dinâmica (como numa espiral) incessante em direção aos objetivos traçados. Este momento pode ser comparado à direção de um automóvel. Planejar não é só calcular sobre o futuro, mas dominar a arte e a ciência de conduzir, de governar, aumentando progressivamente a governabilidade sobre os fatos sociais nos quais o Ator Social que planeja está completamente imerso. Quando alguém guia um automóvel para atingir determinado destino, sua casa, por exemplo, tem a visão focalizada imediatamente à frente, mas deve observar mais adiante também para evitar 
surpresas no itinerário, deve também olhar para trás, pois há outro motorista. Entretanto isto não basta para decidir o melhor itinerário, calcular o tempo gasto e outros detalhes; deve imaginar sua situação de destino (que não vê), mentalizando sua casa e os itinerários possíveis até ela. No momento tático-operacional e no Planejamento Estratégico é assim também. Deve-se concentrar nossa atenção no presente, para ter racionalidade hoje; deve-se, contudo, imaginar objetivos situados a um ou cinco anos no futuro. Entretanto "olhar para frente" não é suficiente, devese aprender com o passado, "olhar para trás" com frequência para melhorar o cálculo sobre o presente em direção aos objetivos futuros.

Neste momento são analisados junto ao grupo quais são os sistemas de direção existentes. São de baixa ou alta responsabilidade? O MAPP requer direções com alta responsabilidade, isto significa, organizações que tem sistema de Pedido e Prestação de Contas de alto a baixo (ninguém fica sem pedir ou prestar contas nos diversos níveis), controle da agenda da direção onde as "urgências" deem lugar às "importâncias" e onde o planejamento seja feito através do processamento técnico-político de problemas (gerência por Operações). A maioria das organizações têm sistemas de baixa responsabilidade, ninguém presta contas a ninguém, planejar significa meramente controlaras rubricas do orçamento, não há processamento (enfrentamento) de problemas que se tomam elementos da "paisagem" (acomodação), as agendas das lideranças e direções estão submetidas às "urgências" que "não têm hora" enquanto as "importâncias" têm que "fazer fila", etc. O momento tático-operacional não termina enquanto o grupo não definir um calendário de atividades, as responsabilidades de cada um diante do Plano (compromisso coletivo), os procedimentos para a Prestação de Contas, analisar as mudanças nas rotinas internas e definir quais entre os participantes serão os responsáveis pela Coordenação Geral do Plano.

Uma direção dominada pelo imediatismo, clientelismo, espontaneísmo e outros atributos dificilmente demandará planejamento estratégico, e ao mesmo tempo, terá como suporte um tipo de organização com estas mesmas "qualidades". E por isso que este enfoque de planejamento requer um outro tipo de organização para ser plenamente eficaz e, ao mesmo tempo, ajuda a resolver tais deficiências, comuns nos movimentos sociais e populares. O MAPP constitui-se, portanto, num potente instrumento metodológico para modernizar a cultura gerencial e administrativa; aliás, os resultados mais efetivos de sua aplicação aparecem quando ele deixa de ser um método simplesmente (com suas regras e nomenclatura) para ser "digerido" culturalmente e incorporado à vida dos grupos que o utilizam. Outra característica, dada sua grande capacidade de flexibilização e adaptação, é a aplicação universal de seus princípios, na íntegra ou parcialmente. O MAPP pode ser utilizado desde uma Secretaria de Governo de um Município (onde os problemas gerenciais são evidentemente mais complexos), até um Sindicado de trabalhadores rurais, uma associação de moradores ou para organização do orçamento doméstico. É um instrumento para enfrentar e diluir problemas, reduzindo sua complexidade e facilitando seu enfrentamento.

\section{O MAPP na prática}

Normalmente um Seminário de Planejamento em MAPP requer por volta de 40 horas para sua execução, a depender da complexidade do grupo e dos problemas selecionados para serem trabalhados. É importante ressaltar que nesta metodologia "planeja quem governa e governa quem planeja", isto é, todos os componentes de uma direção sindical, por exemplo, devem estar presentes e assumir responsabilidade pelo Planejamento (pelas Operações), bem como, pelas mudanças organizacionais necessárias ao gerenciamento do Plano. Não deve existir uma divisão entre os que "pensam e planejam" e os que "obedecem e executam" Outra dimensão é a participação e integração de técnicos e políticos em igual nível no processo.

A execução do Seminário de Planejamento pode ser feita por um ou dois monitores, dependendo dos fatores já mencionados em relação à duração da atividade. O papel do monitor é ser um "facilitador" de situações, do desenvolvimento do grupo, utilizando, se for necessário, diversas técnicas de animação e dinâmicas de grupo compatíveis com cada momento do método.

Um momento essencial do método diz respeito ao que acontece antes de sua utilização pelo grupo assessorado, ou seja, o momento de Sensibilização ou Preparação do Ator. Ele consiste no primeiro contato do grupo (ou de uma comissão representativa), com o método, suas características, os materiais necessários à sua execução, o tempo requerido, 
etc. Todos os momentos e debates dentro do Seminário de Planejamento Estratégico são visualizados permanentemente por todo o grupo através do uso de tarjetas (cartelas de papel) feitas pelos próprios participantes segundo as indicações do Monitor: o roteiro metodológico. A visualização permanente facilita o debate, permite recuperar argumentos ou conceitos já discutidos, ajuda no processo de compreensão e objetiva significativamente as "longas" discussões comuns nos movimentos sociais. Além disso, facilita e agiliza a confecção do relatório, que é um instrumento indispensável para todos os participantes no gerenciamento e acompanhamento do plano elaborado.

\section{Uma experiência concreta}

Nos meses de junho à setembro de 1994, o Centro de Assessoria Multiprofissional desenvolveu o MAPP junto a um conjunto de entidades relacionadas ao tema da infância e juventude, tendo como objetivo organizar o grupo para a realização da I Conferência Municipal de Políticas para a Infância e Juventude/Pacto pela Infância em Porto Alegre, Rio Grande do Sul.

O primeiro momento se constituiu na identificação do Ator Social que estava disposto a planejar a Conferência. Este momento consistiu no debate em tomo de três questões: "Quem somos? O que temos? O que fazemos?". Os recursos foram analisados em relação ao tempo disponível, aos recursos financeiros e materiais, recursos de conhecimento e recursos políticos. Este momento ajudou a criar uma identidade política inicial entre o grupo e certa homogeneização de objetivos quanto ao tipo de Conferência que se queria realizar.

A seguir, desenvolveu-se o momento explicativo, onde foi selecionado um problema central do grupo: "A criança e o adolescente não são considerados sujeitos de direitos e prioridade pela sociedade e governos, na esfera municipal, estadual e federal". A seguir o grupo construiu a "Árvore Explicativa do Problema", identificando três descritores do problema: 1) "os direitos da criança e adolescente não são assegurados e são violados cotidianamente em Porto Alegre (educação, saúde, moradia, lazer e cultura)"; 2) "na destinação dos recursos financeiros, os governos não priorizam as políticas voltadas para a criança e o adolescente" e 3) "no orçamento participativo a população não prioriza a criança e o adolescente". Estes descritores foram explicados por cinco causas fundamentais do problema (Nós Críticos): "(NC1) desigualdade de condições de acesso aos direitos, (NC2) falência das políticas públicas básicas locais, (NC3) desconhecimento do Estatuto da Criança e Adolescente e de sua aplicação pela Sociedade e Governos, (NC4) não temos usado força política para pressionar na destinação das verbas do orçamento público e (NC5) falta de conscientização da sociedade civil frente à questão da criança e adolescente".

O objetivo definido pelo grupo ficou assim estabelecido: "o estabelecimento de parcerias entre parcelas significativas e representativas da população, poder público e pessoas que detém poder, possibilitará que a Criança e Adolescente sejam considerados prioridade e sujeito de direitos" No momento seguinte (normativo), a partir da análise das causas do problema e do objetivos a ser obtido com a realização da Conferência, foram desenhadas 15 Operações com suas respectivas atividades; elas foram agrupadas em quatro grandes projetos: Mídia e Divulgação, Regionalização, Programação e Organização do Evento e Atividades Culturais e de Mobilização. Cada operação foi analisada segundo os recursos necessários para executá-la, seu produto, resultado, prazo e responsável.

A seguir o grupo avaliou o interesse de outros atores sociais de modo a subsidiar a discussão de estratégia de viabilização do plano, ou seja, da conferência. Os Atores selecionados foram classificados quanto à sua posição contrária, favorável ou indiferente em relação ao enfrentamento do problema selecionado. A elaboração de cenários ficou a cargo da Coordenação do Plano durante o processo de gerenciamento.

No quarto momento (Tático-Operacional) desenvolveu-se o debate e as resoluções sobre a divisão de papéis e responsabilidades, a coordenação dos Projetos e do Plano, um Cronograma de Atividades, o mecanismo de prestação de contas e a forma de acompanhamento da assessoria durante a execução das operações.

Algumas conclusões deste trabalho de planejamento que utilizou o MAPP podem ser sintetizadas nos seguintes pontos:

1) O método original foi adaptado segundo a natureza do grupo e as limitações impostas, principalmente pelo pouco tempo disponível. Estas adaptações não prejudicaram o método, mas diminuíram o peso do momento estratégico em relação ao aprofundamento coletivo das estratégias do grupo; 
2) Como se tratava de um grupo relativamente heterogêneo, a pesar da ligação de todas as entidades com o tema da Conferência, uma das maiores dificuldades, anteriores aos problemas colocados pelo uso do MAPP, foi o pouco tempo dado para o debate acerca da identidade do grupo, seu Projeto comum (ou não). Avalia-se que muitas dificuldades encontradas na execução concreta das atividades deve-se a este problema;

3) Considerando as dificuldades encontradas (método novo para a maioria e pouco tempo de trabalho conjunto), a utilização deste enfoque metodológico ajudou o grupo a "organizar suas ideias", discernindo melhor os objetivos de uma conferência desta natureza, os problemas a serem superados para sua execução e as formas organizativas a serem adotadas para viabilizar os resultados esperados.

\section{Referências bibliográficas}

MATUS, C. Política, Planificación y Gobierno. Fundação Altadir, Caracas, 1987.

MATUS, C. Curso de Planificação e Governo - Guia de Análise teórica — Projeto Gestão, Florianópolis, 1991.

PIANEJAMENTO SINDICAL, Cartilha do Monitor, Escola Sul de Formação da CUT, Florianópolis, 1994.

RIVERA, U. (organizador). Planejamento e Programação em Saúde: um enfoque estratégico. Ed. Cortez/Abrasco, São Paulo, 1992.

\section{Psicodramatizando a construção da cidadania: o ser criança e adolescente em um centro de comunidade}

\section{Sissi Malta Neves} $P U C / R S$

As realidades brasileira e latino-americana enfrentam uma profunda crise sociopolítico-econômica, agonizando em seus valores éticos e morais.

O período precioso da infância está sendo suprimido, resultando em seu abandono e extermínio. Milhões de crianças e adolescentes sofrem uma socialização mutiladora nas ruas, nas instituições que as abrigam, nas próprias casas.

Vivemos em um território do paradoxo, sendo o Brasil o primeiro país do mundo em violação dos direitos humanos, conforme relatório da Anistia Internacional, ao mesmo tempo que possui a legislação mais avançada na área da Infância e Juventude representada pelo Estatuto da Criança e do Adolescente (Dalló, 1991)

É urgente que o Estado e a sociedade civil organizada assumam iniciativas reparadoras para a construção da cidadania desses membros.

A presente pesquisa, cujo objeto de estudo é uma proposta de Intervenção Psicossocial por meio de Oficinas de Psicodrama, se justifica pela urgente necessidade de se viabilizar estratégias de atuação junto a crianças e adolescentes no sentido de oferecer possibilidades de legitimação de suas cidadanias.

A metodologia psicológica empregada neste estudo, coloca a ênfase na conscientização dos papéis sociais aprendidos pelos sujeitos. Visa, desse modo, um processo de transformação social possível ao facilitar uma troca de posições dos agentes sociais.

Aquele que, antes, passiva e inconscientemente colocado como reprodutor de papéis demarcados pelo sistema vigente, encontraria um lugar seu, o seu estar no mundo consciente e ativo, forma singular de modificação desse cotidiano. 


\section{O Projeto Jovem Cidadão}

Como política de atendimento a crianças e adolescentes com base no Estatuto da Criança e do Adolescente se desenvolve, em Porto Alegre, o Projeto Jovem Cidadão, desde agosto de 1993. Este é um Projeto de Ampliação e Qualificação do Atendimento à Crianças e Adolescentes em situação de risco social implantado em sete Centros de Comunidade da FESC — Fundação de Educação Social e Comunitária.

Conforme Adorno (apud Rizzini, 1993) entende-se por jovens em situação de risco aqueles pertencentes a segmentos populacionais cujas características de vida - trabalho e profissionalização, saúde, habitação, escolarização, lazer — os colocam entre as fronteiras da legalidade e da ilegalidade, em situação de dependência face às instituições de amparo assistencial e de intervenção legal.

Os Centros de Comunidade atuam como retaguarda a encaminhamentos, feitos pelo Conselho Tutelar da região, de crianças ou adolescentes com envolvimento em furto, drogradição ou que sofrem violência.

Como objetivos deste atendimento se encontram:

1. Ampliar e qualificar o trabalho socioeducativo já existente nos Centros de Comunidade com crianças e adolescentes oriundas de classes populares, para que possam ser referência e retaguarda aos Conselhos Tutelares nas suas regiões;

2. Oportunizar às crianças e adolescentes vivências que possibilitem o resgate da sua história de vida, a constatação e desenvolvimento de suas capacidades individuais e sociais, assim como a elaboração da sua identidade e autoestima;

3. Resgatar ou fortalecer os vínculos familiares, comunitários e escolares, através de um trabalho junto à família e escola, se possível, visando também a integração nas atividades da comunidade;

4. Encaminhar e acompanhar os adolescentes para oficinas profissionalizantes, selecionadas conforme o nível de desenvolvimento de cada um;
5. Possibilitar a construção de conhecimentos referentes à alfabetização quando a reintegração escolar imediata não é possível.

A equipe interdisciplinar que atua com crianças e adolescentes é composta por: duas psicólogas, uma assistente social, duas pedagogas e três professores de educação física. Além dessa equipe específica do Projeto Jovem Cidadão da FESC estão trabalhando conjuntamente alguns oficineiros da SMC na organização de oficinas de criação e expressão cultural e artística.

As ações programadas do referido projeto compreendem os contatos e intercâmbios permanentes com os Conselhos Tutelares, escolas, postos de saúde, associações de moradores e outras instituições que atuam na área da infância e juventude.

$\mathrm{O}$ atendimento obedece à uma rotina que consiste no ingresso de crianças e adolescentes em um turno oposto ao que estão na escola. Quando chegam, fazem o lanche, recebem noções de higienização e, após, o reforço escolar das pedagogas. Durante a semana frequentam as oficinas de psicodrama, artes plásticas, capoeira, jogos e recreação.

Semanalmente, ocorrem assembleias das crianças e adolescentes do Projeto, onde discutem questões referentes ao atendimento, constroem limites na relação com a equipe, tomando decisões coletivas e democráticas quanto à programação de passeios, vídeos, visitas culturais e de lazer.

Quem são crianças e adolescentes das classes populares?

Serão objeto deste trabalho crianças pertencentes a famílias de classes populares. Para isso se faz necessário compreender a estrutura e o funcionamento do grupo familiar dessa camada da população.

A situação da criança e do adolescente é um reflexo das condições em que se encontram suas famílias. Como no Brasil, o Estado não oferece políticas sociais básicas necessárias para o seu desenvolvimento, a desigualdade social compromete, não somente o futuro das populações mais carentes, mas também o da sociedade como um todo.

Como demonstra Ribeiro e Sabóia (apud Rizzini, 1993), a desnutrição, o analfabetismo, a evasão escolar, a entrada precoce no mundo 
do trabalho estão fundamentalmente associados à situação socioeconômica da família.

Condições econômicas extremamente desfavoráveis fazem desses grupos familiares, grupos de sobrevivência, mais do que grupos de vida.

Segundo Lopes (1985), a insuficiência de sistemas sociais de assistência à saúde e à velhice parece estar na origem de uma forte interdependência entre os membros dessas famílias, ocasionando dependência psicológica ligada à dependência econômica.

Essas famílias são frequentemente marcadas pelo abandono ou a morte de um dos cônjuges. Assim, as crianças tem a experiência do grupo familiar como fragmentada - salvo nos casos onde existem parentes que se encarregam de sua educação. O que ocorre somente se houvera contatos entre essas crianças e a grande família no passado para que tenha restado uma espécie de história familiar.

Sugere o autor que, as crianças não acolhidas pelo grupo familiar sejam encaminhadas às instituições de ajuda à infância quando não conseguem um lar substituto (vizinhos ou parentes distantes), permanecendo internas nas instituições em questão.

Devido a condições de vida desfavoráveis, criam-se situações críticas responsáveis pela separação dessas crianças de seu grupo familiar, caracterizando-se, a partir daí, pela ausência de autênticos laços.

Fonseca (apud Rizzini 1993) esclarece as diferenças de atitude frente às crianças entre a classe média e classe trabalhadora. À criança da classe média é atribuída uma série de fases de desenvolvimento emocional e intelectual que exigem cuidados especialmente adaptados e ministrados por adultos específicos.

Esta é a visão da infância reforçada pelas ciências "modernas" da psicologia e da pedagogia, ligadas a um contexto material onde a escola e a família nuclear desempenham os papéis principais de socialização. Para esta criança existe toda uma estratégia familiar de ascensão socioeconômica a ser seguida.

Para a criança da classe trabalhadora, ao contrário das crenças com base na psicologia, próprias das classes médias, o papel de pai ou de mãe responsável não é o de manter uma relação emocional apropriada com seu filho, mas sim o de assegurar que certas necessidades "objetivas" sejam atendidas.

As pesquisas de Fonseca (apud Rizzini, 1993) demonstram que decisões envolvendo crianças, como criá-las, escolarizá-las, seu destino após morte ou divórcio dos pais, não estão confinadas ao casal. O que ocorre comumente é que avós, tios, padrinhos tomam a guarda dos parentes menores diante de situações limites.

Afirma a autora que a instabilidade conjugal, seja por morte, migração ou simplesmente divórcio, é uma constante na história dos grupos populares do Brasil. Se não houvesse a circulação de crianças entre vários adultos como fluxo da "coletivização" da responsabilidade de todo o grupo de parentesco seria mais difícil ainda a sobrevivência desta população.

Atualmente a degradação da família como consequência do momento socioeconômico pelo qual passa a sociedade, viabiliza a seus membros, cada vez mais, experimentarem o estreito e próximo limite entre a vivência familiar de baixa renda e o real abandono das crianças, determinando em alguns casos a experiência institucional das mesmas. É sobre este fenômeno que pretende a presente pesquisa refletir.

\section{Caracterização do Estudo}

Como desafio, no campo da Psicologia Social, surge a necessidade de atuar junto a esta parcela da população e a indagação de como o Psicodrama poderia ser utilizado. Para isso, exige-se um nova linguagem profícua, com uma abordagem corporal adequada, que atinja e permita o desenvolvimento de tal trabalho.

Conforme Patto(1982), a formação que o psicólogo recebe nos cursos de Psicologia contribui para sua atuação alienada e alienante junto às camadas populares.

Coloca a autora que uma verdadeira psicologia popular se configura à partir de estudos realizados por Freire $(1970,1971,1977)$, a respeito da cognição de operários, Moffat (1974), desenvolvendo a psicoterapia do oprimido, e Rodrigues (1978) sobre a representação do mundo e de si mesmos num grupo de operários de ambos os sexos. Todas essas pesquisas são apontadas como ricas fontes teóricas e metodológicas que 
provam ser possível entender e interagir com as populações ditas "marginais" sem os estereótipos e preconceitos existentes na revisão de literatura realizada por ela.

Entretanto, ainda está por ser feita a formulação de um corpo de conhecimentos sobre a dimensão psicológica dos integrantes destes segmentos sociais.

O presente estudo visa compreender a socialização enquanto processo de aquisição de valores, crenças, atitudes e padrões de comportamento de crianças e adolescentes de classes populares, através da vivência grupal destas, em oficinas de psicodrama, num Centro de Comunidade de uma vila de Porto Alegre.

As oficinas de psicodrama ocorrem uma vez por semana, durante uma hora, com grupos cuja faixa etária varia de 7 a 12 anos, no turno da manhã, e de 11 a 14 anos no turno da tarde.

O Psicodrama, desenvolvido por Moreno, coloca os papéis como destaque de sua investigação. O método psicodramático visa apreender, nos vínculos estabelecidos entre indivíduos, as conexões entre papéis e contrapapéis.

Moreno (1978) define papel como a forma real e tangível que o eu adota; expressão objetiva do eu na realidade social. Contrapapel é, pois, uma das pontas na inter-relação entre indivíduos desempenhando papéis.

Outro argumento muito claro encontramos na identificação entre o psíquico e o papel. O papel existe por definição social. O ego procede e se identifica com o papel, sendo lógico concluir que a dimensão social do indivíduo se confunde com seu próprio ego. O homem é um ser social por necessidade.

Os aspectos tangíveis do que é conhecido como ego são os papéis em que este opera. (Garrido Martin, 1978, p. 17).

Assim, desde o primeiro momento de vida, o indivíduo está inserido num contexto histórico, pois as relações entre o adulto e a criança recémnascida seguem um modelo ou padrão que cada sociedade veio desenvolvendo e que considera correta (Lane, 1981).
A socialização realiza-se sempre no contexto de uma estrutura social específica. Logo, a análise microssociológica ou sócio-psicológica dos fenômenos de interiorização deve ter sempre por fundamento a compreensão macrossociológica de seus aspectos estruturais.

Os papéis sociais, com sua estrutura e dinâmicas próprias, repetem e concretizam, num âmbito microssociológico, a estrutura de contradição e oposição básicas que se realizam num âmbito maior entre papéis históricos constituída pela relação dominador-dominado. Nesse sentido a noção de papel aparece necessitando uma complementaridade: o contrapapel, com o qual existe uma relação estrutural, bipolar e de intermediação recíproca (Naffah Neto, 1979).

Enquanto pesquisa do Átomo-social de crianças e adolescentes que utilizam a rua para o seu próprio sustento e daquelas que não necessitam desse locus de sobrevivência, busca-se averiguar como elas percebem seu mundo de relações interpessoais e o consequente aprendizado e desempenho de papéis sociais.

Segundo Moreno (1978), qualquer que seja a psique, originalmente foi formada pelo grupo.

Ao conjunto de vínculos que constituem o campo relacional de cada pessoa se chama Átomo Social (Bustos, 1985). O conceito de átomo social como a mínima e indivisível partícula social representa o núcleo de todos os indivíduos com quem uma pessoa está relacionada emocionalmente.

O átomo social chega a determinar, com sua multiplicidade de critérios, todas as coordenadas de inserção e de aceitação do eu no grupo e pelo grupo. Portanto, o átomo social de um indivíduo diferentemente combinado e inter-relacionado com outros átomos explica a sociedade.

Uma vez constituído o átomo social tem-se que matizar seu caráter através de qualidades ou aspectos que o afetam mais diretamente. A presente pesquisa pretende enfocar essas variações estudando através do átomo social a intensidade com que a criança é aceita ou rechaçada averiguando, também, as variações no átomo por determinações socioeconômicas. 
Como a imagem que o indivíduo tem de si mesmo, além de suas crenças e convicções são mutáveis, pode-se pensar que a transformação da sua autoimagem é passível de alterar o átomo social e vice-versa.

\section{Procedimentos}

No momento atual esta pesquisa encontra-se em fase de coleta de dados.

Os sujeitos em questão se organizam em dois grupos por gênero, na faixa de 7 a 17 anos de idade. Os grupos são constituídos pelos já participantes do Centro de Comunidade e por aqueles convidados a frequentá-lo, através de abordagens na rua.

Os procedimentos para a coleta de dados compreendem o psicodrama, entrevistas, observação com registros cursivos e por meio de vídeo. Os resultados poderão ser obtidos, futuramente, pela análise dos papéis sociais e a análise compreensiva.

Entretanto, algumas observações preliminares já se delineiam no que se refere ao modo como as crianças e adolescentes se vinculam ao Centro de Comunidade. Em sua maioria veem o Centro como um prolongamento da sua casa, e parecem lidar com o espaço físico de maneira a depredá-lo geralmente.

É comum esperarem pelo atendimento de suas solicitações, numa tentativa de que a instituição tenha uma postura assistencialista.

Outros estabelecem com algumas atividades uma relação mais próxima, passando a ser esta a referência do Centro.

\section{Métodos e objetivos}

As oficinas de psicodrama visam desenvolver a expressão corporal e dramática de crianças e adolescentes, utilizando técnicas de sensibilização, trabalho de fantasia dirigi da, a linguagem do teatro espontâneo, jogos dramáticos, recursos gráficos como desenho e pintura, além de materiais como argila, marionetes e brinquedos.

As atividades propostas nas oficinas tentam basicamente resgatar o potencial criativo e espontâneo através de temas a serem trabalhados, tais como, a construção da temporalidade e do projeto de vida, questões relacionadas à identidade de gênero, sexo e raça, e à vivência familiar, escolar e no próprio Centro de Comunidade dos membros do grupo.

Avalia-se a sociometria grupal, ou seja, as relações de atração e rechaço entre os participantes, objetivando uma maior integração de todos.

\section{Referências bibliográficas}

ADORNO, S. "Criança: A Lei e a Cidadania" in I. Rizzini, A Criança no Brasil Hoje. Desafio para o Terceiro Milênio. Rio de Janeiro, Ed. Universidade Santa Úrsula, 1993.

BUSTOS, D. Nuevos Rumbos en Psicoterapia Psicodramática. Buenos Aires, Momento Ed., 1985.

DALló, R. Considerações Acerca da Problemática da Infância e Juventude no Brasil. Palestra do Movimento Nacional de Meninos e Meninas de Rua. Porto Alegre, 1992.

FONSECA, C. "Criança, Família e Desigualdade Social” in I. Rizzini, A Criança no Brasil Hoje. Desafio para o Terceiro Milênio. Rio de Janeiro, Ed. Universidade Santa Úrsula, 1993.

FREIRE, Paulo. Pedagogia do Oprimido. RJ, Paz e Terra, 1970.

FREIRE, Paulo. Educação com Prática da Liberdade. RJ, Paz e Terra, 1971

FREIRE, Paulo. Ação Cultural pela Liberdade. RJ, Paz e Terra, 1978.

GANIDO-MARTIN, E. Jacob Levi Moreno, Psicologia do Encontro. Madrid, Ed. Atenas, 1978.

LANE, S. Psicologia Social. São Paulo, Brasiliense, 1981.

LOPES, V. L. A Família e o Processo de Interiorização. Três exemplos. Arquivos Brasileiros de psicologia, Vol. 37, Julho/setembro, 1985. 106-111.

MOFFAT, A. Psicoterapia del Oprimido. Buenos Aires, Ed. Eca, 1974.

MORENO, J.L. Psicodrama. São Paulo, Cultrix, 1978. 
NAFFAH NETO, A Psicodrama, Descolonizando o Imaginário. São Paulo, Brasiliense, 1979.

PARTO, Maria. Introdução à Psicologia Escolar. São Paulo, Queiroz Ed., 1982.

Porto Alegre. Prefeitura Municipal. Projeto Jovem Cidadão. Porto Alegre, 1993.

RIZZINI, I. A Criança no Brasil Hoje. Desafio para o Terceiro Milênio. Rio de Janeiro, Ed. Universidade Santa Úrsula, 1993.

RODRIGUES, A. Operário, Operária. São Paulo, Ed. Símbolo, 1978.

SABÓIA, A e Ribeiro, R. Crianças e Adolescentes na Década de 80: Condições de Vida e Perspectivas para o Terceiro Milênio. In I. Rizzini, A Criança no Brasil Hoje. Desafio para o Terceiro Milênio. Rio de Janeiro, Ed. Universidade Santa Ursula, 1993.

\section{Pedagogia materna e relações sociais}

Silvia Zanatta Da Ros ${ }^{l}$

UFSC

Começo trazendo uma questão que está presente, hoje, na prática pedagógica e que dela derivam aproximações a um novo referencial teórico e aportes metodológicos que redirecionam as nossas trajetórias profissionais. Esta questão poderia ser formulada inicialmente assim:

— Que relação educativa estabelecem os homens nesta sociedade?

Ou assim:

- O que expressa das relações sociais, a forma de educação, hoje?

Ou ainda:

- Como lidar, no âmbito educacional, com a relação social, individual? Com aquilo que é chamado de realidade interna e de realidade externa? Com a relação conhecimento, afeto e o intelecto?

Objetivando compreendê-las, realizei uma investigação que tomou como objeto de estudo a relação educativa entre mãe-filho, enquanto forma primeira na qual o social é mediado e significado pela figura materna.

$\mathrm{O}$ trabalho não se ateve a pautas metodológicas que processam generalizações a partir da análise da pesquisa. Vai à generalidade para, a partir dela, compreender o discurso das mães, sem a intenção de que esta particularidade explique o geral; ao contrário, tento compreender de que maneira as tendências que movimentam o real, movimentam ou estão presentes, também, na dinâmica que envolve a relação educativa entre mãe e filho.

O trabalho foi realizado a partir do convívio e de entrevistas com mães da chamada classe subalterna, direta e indiretamente relacionadas ao trabalho produtivo, seguidos de discussões aprofundadas com profissionais envolvidos em programas de educação infantil de quatro municípios do Estado de Santa Catarina. Teve como fonte minha dissertação de Mestrado

${ }^{1}$ Professora do Departamento de Estudos Especializados em Educações. Centro de Ciências da Educação. Universidade Federal de Santa Catarina. 
em Educação realizado no Centro de Ciências da Educação da Universidade Federal de Santa Catarina.

A investigação permitiu destacar algumas mediações, cujo conteúdo é histórico e está colado à materialidade, bem como apreender o significado das mesmas, na sociedade capitalista.

Possibilitou compreender a forma que a mediação toma na relação pedagógica do grupo familiar, cuja síntese se vê expressa no discurso e no repertório educacional materno. Traz, assim, os resultados e, ao mesmo tempo, os pressupostos das relações sociais caracterizando os processos naturais de educação materna como processos social e culturalmente determinados. Permitiu apreender, também, na pedagogia materna, os elementos de resistência aos mandos do movimento que reedita as formas que afirmam a organização social atual.

Este movimento foi possível porque pude desprender-me do referencial teórico presente até então em minha prática pedagógica no que se refere à dinâmica das relações humanas. Tinha como ponto de partida o que é considerado realidade interna, isto é, a dinâmica dos processos mentais individuais através dos quais a compreensão do indivíduo baseavase na forma como ele organiza internamente suas vivências.

Numa outra perspectiva, vislumbrando não o individual, não a realidade interna mas o histórico cultural, colocando nele o determinante da dinâmica das interações que se processam nas relações humanas, é possível compreender que, já no primeiro elo afetivo e educativo se vê presente o social, o cultural. Neste sentido, os expedientes que não considerados naturais na infância, são isto sim, sociais - possuem a marca deste social. Cada um deles traz uma expectativa, uma forma concreta de existência, de relacionamento humano, marcado pela classe social a que pertence. Trago a fala de uma mãe (Morro da Cruz Porto Alegre), que, como resposta à solicitação de colo por parte de seu filho, lhe diz: "Tá doido, neguinho, tá pensando que tu é rico!". Várias interpretações caberiam a esta fala, mas cabe, também, e especificamente a de que ela expressa, sem dúvidas, as relações sociais.

Das muitas tentativas, na procura de um método de pesquisa que contemplasse estas questões, relato três, basicamente.
Faço uma breve exposição de cada uma delas no sentido de mostrar que podem ser feitas diferentes leituras da realidade sem que elas nos permitam compreender a totalidade da relação homem e sociedade.

1. A primeira tentativa resultou na explicação da aparência pela aparência, na qual o ritual da pesquisa fez com que eu perdesse meu lugar de sujeito da investigação para os instrumentos da pesquisa. Nem eu nem as mães nem seus filhos eram sujeitos.

Éramos, sim, formas autônomas, dicotomizadas. Fazer ciência, neste momento, passou a ser um ato mecânico, uma relação de fatos que transformava a doxa em episteme, a opinião em conhecimento, pelo simples fato de trazer em si aquilo que eu considerava verdade do cotidiano materno.

A história de Ibirama, cidade onde iniciei este trabalho, a vida das mães e as relações educativas apareciam dissociadas do social e as conclusões me permitiam ver que a industrialização brusca, pela qual Ibirama havia passado, tinha roubado a identidade das mães, e que por isto a relação educativa com seus filhos era tão pobre.

Fato óbvio, não precisava pesquisa para concluir isto. Era uma aproximação que apenas descrevia fatos, retratava um fenômeno, longe de aproximar-me à totalidade do social. Era a parte explicada pela parte.

2. Na segunda tentativa, abandono o material já produzido e vou às relações sociais, à evolução das relações dos homens na produção de suas existências, dos fatos mais simples aos mais complexos. Vejo, depois da tarefa cumprida, que eu apenas havia sequenciado os fatos históricos, cronologizado a transformação que sofreram no tempo e que tinha sido privilegiada a natureza destes fatos sem que fosse possível compreender as necessidades que motivaram a produção destas transformações.

Ficou privilegiada a ideia de natureza humana inata, do pressuposto de necessidades humanas inatas, de que as coisas aconteciam e evoluíam porque era da essência dos homens fazer acontecer. Conclusão final: a realidade é assim, porque é. Eu me perguntava: Cadê a ciência?

3. Depois de ter visto a categoria totalidade se esfacelar pela descrição isolada das partes ou pelo evolucionismo, tomando como natural aquilo que é social, pude redirecionar a investigação e partir para uma terceira e última forma. 
Neste momento da pesquisa, tive oportunidade de participar de uma reunião com pais e mães envolvidos no programa de Creches Domiciliares que discutia fundamentalmente problemas no desenvolvimento infantil. Aí uma das mães receitou para uma criança de 18 meses, que não caminhava: "É bom dar banho com água de suor do trabalho do pai”.

Fui ao contexto popular para ver que relação a receita tinha com a maternagem, com a educação, com a industrialização, com as flores das casas alemãs, polacas, italianas, com o desenvolvimento neuropsicomotor...

Ensaiei algumas compreensões: de que o trabalho dignifica, que faz os homens crescerem e que portanto a mensagem afetiva que estava sendo passada, a de crescer e caminhar, era a responsável pelo sucesso do ritual. Ou então: de que o trabalho produz o homem, e o ritual transfere para o filho a mensagem de que ele se faça um homem que caminhe, a partir da identificação com o pai.

Aí começaram a aparecer contradições que feriam as premissas teóricas adotadas. O homem e a sociedade se mostravam como formas dicotomizadas, dissociadas. Aparece neste ritual uma definição de trabalho na qual o trabalho faz o homem e não o homem se faz pelo trabalho, e que frente a qualquer falha na vida deste homem basta que se corrija com algo externo a ele para que ele continue se desenvolvendo de acordo com sua tendência natural.

Era uma visão fetichizada. Negadora de que os homens organizam sua vida pelo trabalho, mas não pelo trabalho natural, e sim por aquele da sociedade capitalista que universaliza a relação entre os homens pelo Trabalho Humano Abstrato substância social que equipara todos os produtos do trabalho do homem. Negadora, também, de que mesmo que fosse somente uma mensagem afetiva, o afeto possui formas históricas e que existe relação entre o desenvolvimento psicológico da criança e os aspectos culturais, entre a evolução das funções psíquicas e a "assimilação individual da experiência histórica”, como aponta Leontiev (1978).

As referências teóricas que delinearam, a partir de então, as relações do específico com a totalidade tiveram como base duas ideias fundamentais, na tentativa de compreender a natureza sócio-histórica do psiquismo humano:
- que compreende o homem como síntese das relações sociais, em Marx e Angels (1977);

— a de que todos os homens são filósofos, em Gramsci (1981).

A primeira marca uma concepção materialista de homem, portanto não idealista e nem aquela mecanicista que condiciona o homem reflexa e passivamente às relações sociais. O homem é síntese das relações sociais e traz em si, em sua individualidade, todas as contradições deste momento histórico e, se a sociedade é fetichizada, o homem traz em si o fetiche.

A segunda premissa - todos os homens são filósofos — permitiu apreender da representação do senso comum, da filosofia espontânea posta no discurso materno, que esta representação do mundo expressa, da totalidade, uma face do social que organiza os homens na sociedade e que organiza os homens em sua individualidade.

Assim, nesta relação homem e sociedade, não podemos falar de mundo interno e mundo externo de forma estanque mas sim que o pensamento em qualquer de suas formas é expressão da realidade. Como na sociedade da mercadoria, o trabalho coletivo retirou o homem, enquanto indivíduo, de cena, e a mercadoria não é uma mesa, um livro, é apenas uma coisa, porque traduz valor; as pessoas também manifestam em seus atos e pensamento a coisificação que se universaliza.

Que educação emana destas condições e como é expressa? O que a consciência permite intuir desta realidade, uma vez que, segundo Vygotsky (1979), a consciência é a vida tornada consciente? E, o que estas relações coisificadas escondem atrás de si? Uma relação entre coisas, entre mercadorias, uma relação humana?

Do discurso materno que se mostrou obscuro no primeiro momento como se estivesse envolto numa penumbra epistemológica, encontramos o fetiche, os segredos.

O discurso foi obtido através do convívio com as mães, do diálogo espontâneo, das visitas, das reuniões e das entrevistas realizadas mediante um roteiro previamente estabelecido sobre os temas: Sociedade, Trabalho e Educação.

Foi possível perceber que, nesta sociedade na qual a realidade está encoberta e não se mostra de forma clara, nesta sociedade do paradoxo, o 
discurso tece uma malha de mensagens e contramensagens que cinde o homem, que o paralisa. Os discursos maternos trazem conteúdos com 200 anos de atraso, reeditando preceitos de uma história passada, de um momento já acabado, a-historicizando o homem, e propondo um recuo com reedição, justamente, de uma identidade que já não é mais a sua.

O discurso traz a forma negadora que afirma que não há diferença entre homens, que não há classes sociais.

Lúcia, uma das mães entrevistadas, me dizia que "nesta história de pobre e rico, de preto e branco, tem um mistério que não dá para compreender". Já Elena me dizia que tem muitos segredos na sociedade. Que "eles" fazem tudo na calada da noite e que, se estes segredos forem descobertos, desmontaria tudo. Elena não pode me dizer que o desmontar de tudo não acontecerá somente com as ideias dos homens, esqueceu que a materialidade tem seu movimento e que homem e sociedade não estão desgrudados. O discurso cultua o indivíduo, como se dele, de seu esforço para crescer, fosse possível ascender socialmente. Traz as máximas do liberalismo. Traz a negação de que, neste modo de produção de vida, o homem não é sujeito.

Neste contexto social do homem sujeito/não sujeito, se aninham as pedagogias que preparam as crianças para a vida nas relações educativas do seio familiar.

Apareceram repetidas vezes as projeções paternas, nas quais as mães definem a vontade dos filhos, representando um papel de agentes externos, confirmando que na sociedade de homens não históricos, as definições são externas a eles, são das coisas, das mercadorias e não da relação dos homens entre si. As duplas mensagens supervalorizam o indivíduo para esconder que ele não importa nesta sociedade.

Reeditam-se preceitos do passado, são chamadas da história roupagens de um outro tempo... "para, com este disfarce de velhice venerável e esta linguagem emprestada, representar a nova cena histórica", como dizem Marx e Engels(1982), no Dezoito de Brumário.

Mas o discurso expressa também uma teimosia. É assim que Janete diz para o filho: "Cai e levanta. A comida eu boto na mão dele, mas é ele quem tem que comer".
Os discursos revelam também que é possível romper com a pedagogia do natural, com a pedagogia do recuo. O discurso materno é um discurso criador da "zona de desenvolvimento proximal" (Vygotski, 1979).

Paradoxalmente, ao discurso a-historicizante, cujo modelo de identidade é aquele não pessoal, mas coisificado pelas mercadorias, há também discursos voltados ao vir-a-ser. A identidade aqui parece ainda não palpável, no sentido de que não possui contorno completamente delineado, mas contém em si algo que vislumbra o novo. E à espera do novo corresponde a zona de desenvolvimento proximal, mediada pela possibilidade de que o viver dos homens seja marcado por uma síntese qualitamente mais humana do que aquela que organiza o viver neste modo de produção.

É do enfrentamento dialético com esta realidade que brotam pedagogias que podem afirmar ou negar esta realidade. À pedagogia materna, em determinadas situações, cabe cumprir com o papel dissimulador de negação, tomando natural tudo aquilo que é social onde:

- o antagonismo das classes é tido como algo natural;

- a luta pela propriedade das coisas, na conquista da cidadania, se efetiva no fato de possuir mercadorias;

— é do indivíduo, e somente dele, a responsabilidade de crescer na vida;

- o fetiche faz com que o indivíduo pense o organismo coletivo como uma entidade estranha a si, transformando-o num fantasma que impõe relações duralistas, paradoxais com este social, no qual o indivíduo não compõe com ele uma totalidade orgânica. Assim, os indivíduos são estranhos um aos outros. Não possuem uma identidade social - daí contemplarem o coletivo como se dele não fizessem parte. Dali a "lei do Gerson" (Costa, 1988).

— há negação da infância na forma de desvalia ou de hipervalorização da criança. A mesma desvalia que uma das mães caracteriza, em seu discurso, os pobres, os trabalhadores, os pequenos. "Pobre mesmo não faz nada, só trabalha". Esta desvalia que está traduzida no discurso da mãe não é somente uma opinião dela, não é uma atitude de rejeição. É antes de tudo, uma verdade do capital que a mãe expressa no seu discurso, como se o capital se apropriasse da sua boca falasse com a sua voz. 
Fica posto, também, que a família não existe mais, que a mãe não existe mais, e que, os papéis naturais dos membros que compõe a família estão vazios, uma vez que o capital ocupou-se em institucionalizar, colocando fora da família, os encargos que seriam dela: implementou num determinado sentido a escola, a pré-escola, os especialistas, os postos de puericultura.

A escola aparece no discurso das mães como a "instituição que ensina as primeiras letras" (conforme disse Janete) e que "dependendo do tanto que estuda poderá ser mandante, poderá ser o dono". Fala da escola para situar hierarquicamente o indivíduo na produção A escola é, também, a saída possível para a ascensão social, para que se construa enquanto cidadão para "ser da sociedade".

A escola ensina e a família educa. A educação da família tem a ver com valores pessoais. É natural para Elena que nem todos estudem. "Se todos tivessem estudo, não existia operário". É o princípio educativo da subserviência ao social que lhe aponta o caminho da classe social a que pertence.

No entanto, um modo de transgressão é aquele apontado por vó Aida que as crianças precisam gozar a infância, que assim podem se tomar independentes.

Os meus filhos não gozaram a infância. São trabalhadores, honestos, direitos, mas são bobos, não compram uma camisa sozinhos. Eu fiz eles ficarem assim. Os meus netos, que são os meus filhos agora, vão ser trabalhadores, mas vão ser inteligentes. Vê o pequeno, ele vê uma coisa e já associa com outra - vê uma lata de óleo e já diz carro.

O que expressa esta intuição? Que nesta malha de mensagens e contramensagens, na obscuridade com a qual as forças produtivas se mostram, uma ruptura poderá mostrar um homem novo? Que é possível romper com a pedagogia do natural, com a pedagogia do recuo? Que definições, que caminhos se abrem?

Não elaborei definições sobre o papel da mãe, sobre a educação, sobre o ser criança e nem cheguei a conclusões absolutas sobre a relação educativa. Pude apreender sim, a forma que a totalidade das relações sociais aparece nesta relação e a aparência que toma diante da história. A busca foi de apreender no primeiro vínculo humano sua face educativa e como a apropriação do social, pelo pensamento, manifesta a consciência do novo ou apenas reproduz o velho.

Busquei ver as leis que brotam da relação que faz o velho aparecer como novo, a relação da mudança com a não mudança, tendo como ponto central o social, o cultural e a maneira como isto se transforma em pautas educativas que norteiam comportamentos, exigências, expectativas, qualidade de investimentos afetivos, com frustrações ou gratificações que se encontram com relações sociais que privilegiam uns e outros destes aspectos acima citados, de acordo com o movimento da materialidade, na luta que ela realiza por afirmar-se ou negar-se.

Pude compreender que toda relação humana é educativa, entremeando aspectos intelectuais e afetivos que tem como base, como conteúdo a relação material que organiza os homens. Cada individualidade expressa as leis de funcionamento do social, revesti das de características fetichizadas que aparecem sempre, no fetiche, como relações materiais, relações entre coisas.

Este processo esconde os mecanismos que os engendram. É do enfrentamento dialético com esta realidade que brotam as formas de consciência e da educação que poderão afirmar ou negar esta realidade. A pedagogia materna, em determinadas situações, cumpre, somente, com o papel dissimulador de negação da realidade social. Aí, são introduzidos novos papéis relacionados a uma nova normalidade com imposição contradições em sua base:

- a de educar indivíduos para não serem indivíduos; a de superindividualizar para negar que existem classes sociais; a do deslocamento da identificação com as figuras paternas para a identificação com a autoridade idealizada ao trabalho assalariado ou, em outro extremo, com figuras que representam determinadas formas de enfrentamento característica dos chamados marginais.

O não enfrentamento dos conflitos também manifesta este condicionamento contraditório, aparecendo sob a forma da educação da falsa moral. Elena retira sua filha das brigas da rua com outros colegas da escola porque é feio brigar - talvez, na verdade, a mensagem fosse: é feio enfrentar. Afinal, enfrentar o quê, se neste sociedade não existe conflito? 
Mas a pedagogia materna impõe também uma teimosia: a de que o homem teime em continuar sonhando.

É assim que as mães e avós que participaram da construção deste trabalho apostam no desenvolvimento potencial (Vygotski, 1979) das crianças. É assim que as próprias crianças desafiam a si mesmas...

O trabalho pesado (na roça, na lavação de carros do estacionamento), a responsabilidade prematura na lida da casa ou com o cuidado dos irmãos mais novos, caleja suas infâncias mas prepara-os para o enfrentamento de coisas também pesadas... A mãe que nega colo ao filho sabe que o preparo para enfrentar oito ou mais horas de trabalho ao sol e mal alimentado, requer exercício desde cedo.

É deste exercício, associado ao que vó Aida chama de inteligente, quando seu neto dá mostras de enfrentar a realidade, passando por relações, e da expectativa de que eles rompam com a educação da dependência, da sobrevivência (que faz com que seus filhos não comprem uma camisa sozinhos), que nasce a zona de desenvolvimento proximal que aponta, talvez, para novos rumos..

Que este homem não venha tão devagar! Ele mesmo é propriedade de si. Que, frente à máxima da a-historicidade, prevaleça o homem historicamente situado e alerta. Caso contrário vingará o espectro, e a pedagogia do recuo ganhará vida, retardará o encontro do homem consigo mesmo.

\section{Referências Bibliográficas}

COSTA, Jurandir Freire. “A lei do Gerson”. Revista Isto é / Senhor. São Paulo: Três, nº 982, 1988, pág. 3-7.

GRAMSCI, Antonio. Concepção dialética da história. Rio de Janeiro: Civilização Brasileira, 1981.

MARX, K., ENGELS, F. A ideologia alemã. São Paulo: Grijalbo, 1977.

. Obras escolhidas. Moscou: Edições Progresso, 1982.

VYGOTSKY, L.S. El desarrollo de los procesos psicologicos superiores. Barcelona: Grijalbo, 1979.

\section{Revisitando a educação popular a partir das mulheres Papeleiras}

Nilton Bueno Fischer

$N E P$

Alcindo Antônio Feria

$N E P$ - UFRGS/PMPA

\section{Introdução}

Educação Popular, hoje, pode parecer uma temática antiga e nostálgica para aqueles que, nos anos 60, estiveram envolvidos nos projetos militantes orientados por intelectuais e educadores populares. Passados mais de 30 anos, as mudanças ocorridas na sociedade brasileira trouxeram consigo a demanda de revisitação aos referenciais teóricos e metodológicos usados por educadores populares da época, especialmente em seus novos campos de atuação.

Assim, diferentemente do discurso homogenizador que se apresentava há três décadas, o movimento possível para os intelectuais e educadores, atualmente, é a reconstrução da cidadania dignificada, da qualificação da vida e da escolha de futuro. Passando, essa reconstrução, pelo reconhecimento das especificidades das trajetórias e da diversidade das condições de vida dos trabalhadores (gênero, desenraizamento, ocupações, representações, histórias de vida, subjetividades, etc.).

Temos tido uma possibilidade privilegiada de conviver com um espectro bastante extenso dessas diferenças através de projetos agenciados pelo Núcleo de Estudos, Pesquisas e Assessoria em Educação Popular NEP. Nesse Núcleo, localizado junto ao Programa de Pós-Graduação em Educação da UFRGS, estão abrigadas diversas pesquisas na área da Educação Popular e projetos de assessoramento em educação, saúde e assistência (na perspectiva das políticas públicas), o trabalho educativo e a comunicação popular.

É exatamente do projeto que acompanha a ação desse Núcleo desde seu início, que se fará a reflexão que organiza este texto: o assessoramento aos educadores populares que atuam junto às mulheres papeleiras da periferia de Porto Alegre e região metropolitana. 
Desde 1987, no entardecer de todas as quartas-feiras. reúnem-se educadores, mulheres papeleiras (inicialmente dos galpões da Ilha Grande dos Marinheiros, depois da Vila Santíssima Trindade e da Wenceslau Fontoura), representantes do Governo Municipal, pesquisadores, técnicos e outros representantes de Entidades Não Governamentais.

A dinâmica das reuniões se faz através de uma pauta construída para cada encontro. Existem variadas temáticas envolvendo o funcionamento técnico dos galpões das mulheres papeleiras (problemas de produção, estragos nos equipamentos. pesagem do lixo, etc.); as questões econômicas (comercialização. sistema de pagamentos. programação de investimentos. etc.); as relações interpessoais (entre as trabalhadoras. com os representantes do poder público, com os agentes de Educação Popular); e as questões políticos (organização de cada galpão. entre os diversos galpões, organização e participação em eventos. elaboração de estratégias e propostas de ação frente as políticas públicas do governo municipal: coleta seletiva e projetos de geração de renda, saúde, educação e assistência social).

Sinalizando uma face do papel de mediação o qual caracterizaremos posteriormente, uma das observações mais precoces nesse processo foi a diversidade das maneiras de atuar de cada um dos educadores em relação às mulheres papeleiras nos diferentes galpões. Existem pessoas com experiências variadas em trabalhos com classes populares de periferia urbana e outros com maior formação profissional ou acadêmica. A plural presença de educadores com diferentes orientações religiosas também favorece um debate muito respeitoso e com explicitação dessas diferenças.

A constatação da pluralidade apontou a necessidade de um aprendizado dos educadores para o agenciamento de uma saída da esfera da experiência e do voluntariado, que são insuficientes para a ultrapassagem dos padrões de qualidade do trabalho (gerador da renda para as mulheres).

Em outras palavras, o aperfeiçoamento dos educadores populares também foi, e está sendo, concomitante com a necessidade de melhorar as condições de trabalho, saindo do exótico de trabalhar com o lixo, reciclando-o para uma instância organizativa (tipo cooperativa) mais eficiente técnica-econômica e socialmente.

Para isso, é decisiva a explicitação das relações entre os diferentes sujeitos do trabalho (pesquisadores, educadores e trabalhadoras), o desvelamento de como se processam os conhecimentos a respeito do trabalho e da exploração que se estatui na nossa sociedade e como essas questões podem colaborar para o entendimento da totalidade social.

Um breve passeio pela construção e localização do lixo no cotidiano das cidades e na cultura e a definição da categoria mediação contribuirão para nossa reflexão.

\section{Dos fragmentos do lixo à globalidade da economia}

$\mathrm{O}$ entendimento da questão do lixo urbano não pode se restringir à lixeira onde o depositamos ou aos locais em que é desprezado após a coleta. Novamente, aqui é necessária uma mediação entre alguns valores da cultura e o resgate de processos sociais para sua compreensão.

No trabalho intitulado $A$ inserção do trabalho de reciclagem do lixo urbano no sistema social de produção como um processo educativo, a pesquisadora Russel da Rosa (1994) reconstruiu, através de uma complexa reflexão teórica, "o processo de desodorização progressiva das pessoas e dos ambientes, guiado por um discurso médico-sanitarista associado à crescente privatização da vida e controle dos 'instintos', primeiramente dos membros da família burguesa em ascensão, como forma de distinção social, e progressivamente da sociedade em geral como valor", que se verificou com o advento da Revolução Industrial. Assim, o lugar de segregação se constituiu tanto para o lixo, que "deve sair do alcance dos olhos e do nariz, perdendo a visibilidade", como para as catadoras (mulheres, migrantes, excluídas do sistema formal de produção e consumo como consequência do processo de desenvolvimento social, marginalizadas no território da cidade, inseridas no sistema informal de produção e, ainda mais, trabalhando com o lixo - objeto desprezado pela cidade).

O processo social de exclusão das classes populares no Brasil, orientado pelas políticas econômicas recessivas, também intervém em qualquer análise mais aprofundada sobre os processos de trabalho a partir do lixo urbano. A presença do catador de papel no cenário urbano brasileiro, das migrações internas e da periferização nas grandes cidades são o lado avesso da industrialização predatória e da concentração de riquezas e propriedades. 
Por outro lado, também as criativas teias do sistema informal de produção e consumo têm origem nesse processo. Destes, interessa-nos destacar a complexidade do processo de reciclagem de lixo urbano, enquanto um processo de trabalho que permite a reentrada de materiais no ciclo da produção e consumo.

Esse processo vai desde a catação de restos nos lixões urbanos, para a alimentação, à "complexa rede de relações sociais e procedimentos técnicos para o reaproveitamento de materiais que em algum momento foram considerados inúteis e descartados sob a forma de lixo" (ROSA, 1994) que se processa na reciclagem de lixo urbano. O processo de reciclagem compreende, primeiro, a separação e classificação dos diferentes tipos de materiais e, posteriormente, o armazenamento, o transporte e a comercialização desses materiais, que serão utilizados como matériasprimas por fábricas, indústrias ou usinas de reciclagem.

Como se vê, existe um contexto de diferença e segregação bastante particular nos espaços do lixo que, tão verdadeiro como é o potencial educativo e de inclusão social que têm, implica em mediações de diversas ordens para ser compreendido e potencializado.

\section{Educação popular e mediação}

A construção da categoria mediação na trajetória da Educação Popular vem sendo gestada desde que, principalmente a partir da década de 60, esteve impregnada pela perspectiva de "libertação para as classes subalternas". Nessa época, partindo da lacuna criada pela temática da modernização ("transição de uma sociedade pobre, atrasada e desigual para uma sociedade industrializada, urbana e universal"), fértil na década anterior, foi sendo preparado o espaço para a ação de fora e de cima, especialmente do Estado e dos partidos políticos, para a "ordenação" das classes populares (FISCHER, 1995).

As análises acadêmicas desse período, centradas nos trabalhadores urbanos e fabris, reforçam a imagem da negatividade nas classes trabalhadoras, obstaculizadas para a constituição de uma classe real por serem consideradas "imaturas, heterogêneas, sem vocação para a solidariedade e para a universalidade" (imagem sugerida por SADER \& PAOLI, 1986). Associando-se a essa imagem, o atrasado processo de modernização do setor produtivo, reforça a necessidade da presença do Estado para a sua tarefa de disciplinamento das relações sociais. Como reflexo da necessidade de mudanças sociais mais imediatas, um certo nacionalismo estimulou, também, a migração de setores de vanguarda intelectual para o convívio com as populações periféricas para educá-las com suas iluminadas mensagens, via de regra, deslocadas e estranhas às realidades em que se inseriam.

Segundo Brandão (1985), nessa época não existiam "projetos de transformação global de estruturas, mesmo culturais, onde o povo fosse chamado a ser não apenas um beneficiário marginal dos efeitos da luta, mas também e principalmente um de seus sujeitos participantes". Para esse autor, por ingenuidade ou colonialismo disfarçado, esses projetos reduziram as classes populares a consumidores do que lhes era oferecido.

Aos poucos, surge uma reflexão questionadora da centralidade do Estado como exclusiva instância organizadora da ordem numa sociedade desigual e atrasada. A sociedade civil, diversa e plural, é indagada sobre como ela pode também gerar transformações, "transformações históricas em direção à liberdade e à democracia" (SADER \& PAOLI, 1986). Esses questionamentos partem principalmente de pesquisadores dispostos a "realizar uma produção científica através da combinação harmônica (e ao mesmo tempo dinâmica) entre a experiência (...) junto aos movimentos populares e aos referenciais teóricos de sustentação do seu trabalho" (FISCHER, 1995). É assim que, desde os olhares de diferentes áreas do conhecimento, vão sendo identificadas em meio às, supostamente homogêneas, massas de operários, movimentos históricos do operariado, experiências e modos de vida na constituição dos lugares simbólicos nas relações e nos conflitos do âmbito do trabalho, espaços de enfrentamento onde se constitui a classe na especificidade de cada situação e, finalmente, versões da história que resgatam não apenas o lugar oficial dos vencedores, mas também a história dos vencidos. Assim, vão se constituindo enfoques teóricos potentes na demonstração da quase totalidade das manifestações sociais e no resgate dos cidadãos das classes trabalhadoras.

Mesmo enquanto surgem proposições descontrutivistas no cenário da produção acadêmica, anunciando o fim das metateorias e utopias, emerge nesse tempo da história o revigoramento do sonho de uma sociedade mais humana, justa e vitalizada. Há um projeto de liberdade humana se 
construindo a partir de caminhos que continuam a reflexão advinda de práticas diversas e, com isso, ressignificando categorias teóricas, sem caírem no relativismo. Essa revitalização potencializa o trabalho de estudos, pesquisas e assessoria, particularmente na área da Educação Popular, porque a sensibilidade ao diferente, ao outro, enquanto expressa com sinais vivos de troca, pode tomar permanente o movimento de qualificação de referenciais dos envolvidos - trabalhadores, operários, educadores e pesquisadores - e, mais ainda, transformá-lo num ato prazeroso. Está aí anunciado, no trânsito entre as diversas instituições sociais (partidos, grupos religiosos, classes populares, Estado, gêneros, ocupações, etc.) o papel de mediação dos educadores populares. A esses se soma, e certamente merece destaque, uma outra face necessária dessa mediação: aquela referente aos conhecimentos, particularmente quando um dos lados da relação representa a academia. Para essa mediação são necessários, além dos trânsitos entre as diferentes disciplinas de âmbito formal - cujo percurso teórico já foi apropriado pelas formulações da inter/transdisciplinaridade - mas, igualmente, entre estas e o concreto vivido, as representações e os saberes informais dos cidadãos das classes trabalhadoras. Nessa perspectiva relacional entre sujeitos de classes sociais diferentes, são criadas instâncias de construção e apropriação de conhecimentos, num processo efetivamente educativo e transformador para todos os envolvidos.

E nessa perspectiva também, a experiência com as mulheres papeleiras é desafiadora.

\section{Mediações como método de trabalho}

Cabe, então, retomar algumas das faces da mediação descrita preliminarmente para, com um intuito mais didático do que generalizador, avançar na sua descrição. Vale retomar que até aqui essa mediação foi proposta como uma espécie de trânsito, de troca, de complementaridade através da produção de novos conhecimentos entre os sujeitos do processo educativo, visando a reconstrução de uma sociedade mais justa e vitalizada, através do desenvolvimento de uma ética voltada para a defesa e qualificação da vida e da construção de futuro.

Para reforçar o papel da mediação, também se destacaram as diferenças entre os mundos que coexistem nos espaços da reciclagem e no seu entorno: as diferentes religiões, as formas de se constituírem famílias, as relações com o mundo do trabalho, as etnias, as violências do mundo da droga e de seu tráfico, as presenças de múltiplas assessorias (universidades com projetos de pesquisa e extensão, partidos políticos na formação de quadros, projetos de educação popular diferenciados, poder público municipal e estadual), as diferentes ofertas de serviços e equipamentos públicos: escolas, creches, serviços de saúde etc.

Dizíamos que uma das faces desse processo era a mediação entre os diferentes conhecimentos dos sujeitos envolvidos. Isso significa, de um lado, a socialização de representações, isto é, imagens, conceitos, categorias, teorias e componentes cognitivos, segundo SPINK (1993), acerca do trabalho, da realidade e da militância, de forma a possibilitarem uma verdadeira comunicação entre os sujeitos. Tendo o cuidado de observar que, no tempo da convivência, o que não é compreendido de modo imediato não significa inexistência de conhecimento.

Está aí presente a mediação na perspectiva epistemológica na qual, através da práxis humana, se realiza a consciência e seu objeto. Nesse sentido, nessa relação entre sujeito cognocente e mundo vivido, há um movimento permanente o qual não deixa o pensamento petrificarse (FISCHER, 1995).

De outro lado, essa socialização também significa o compartilhamento dos conhecimentos que permitem identificar como se processam socialmente os mecanismos de exploração, como circulam os produtos e as diversas valorações sociais que transitam pela cultura, incluídas as diferentes perspectivas de realização dos saberes dos assessores.

Está aí apontada uma outra face, a mediação entre as diferentes culturas. E, aqui, mais do que reiterar os trânsitos descritos queremos incluir as formulações de Ecléa Bosi (1987) sobre a cultura popular. Para essa autora, ao invés de pensar na ausência de cultura pela condição de migrante associada pelo processo social às classes trabalhadoras (migração geográfica e social), "seria mais justo pensar a cultura (...) em termos de desenraizamento. Não buscar o que se perdeu: as raízes já foram arrancadas, mas procurar o que pode renascer nessa terra de erosão". O trânsito com a cultura urbana, com o lugar do lixo na cultura, com as divisões sexuais, com os credos e com os rituais são pistas para pensar no espectro dessa mediação. 
A mediação com as diversas entidades que atuam no mesmo espaço, para além de evitar a duplicidade de esforços, auxilia na construção de efetivas possibilidades de atuar sobre as condições de vida, prevenindo conflitos e sobreposições, além de acenar com uma possibilidade efetivamente coletiva de ação. Assim, no entorno dos galpões, os diversos serviços assistenciais, em particular de saúde e educação, os postos de polícia e as ONGs representam uma possibilidade de articulação que precisa ser construída pela convivência. A articulação com o Poder Público no que se refere ao gerenciamento dos resíduos sólidos urbanos representa um desafio adicional na manutenção de projetos de reciclagem. Para além dos papéis de fiscalização e normalização que geralmente desempenha, pode ter uma função parceira na incidência na cultura da coleta doméstica, no encaminhamento de materiais aos galpões de reciclagem e na estruturação e manutenção de projetos de implantação de unidades industriais de produção de matérias-primas - com maior valorização e competitividade no mercado. Essa é uma parceria que está se desenvolvendo positivamente, com percalços e retrocessos, nos galpões em Porto Alegre.

Um último destaque: a mediação entre as instâncias de produção $e$ consumo dos materiais reciclados. Para além da mediação homem/natureza que é a possibilidade clássica de entendimento do trabalho, aqui reforçada pelo caráter ecológico que está associado à reciclagem de lixo urbano, tratase de reiterar a possibilidade educativa de qualificação do trabalho possível com a ampliação das informações técnicas apropriadas pelos trabalhadores. A qualidade de vida, na parcela obtida através da remuneração pelo trabalho realizado, tem avanços na medida da qualificação e profissionalização do processo de produção. E para isso já existem disponíveis tecnologias e conhecimentos que precisam ser acessados e utilizados, certamente de maior facilidade para os educadores populares.

Essa reflexão sobre as diversas mediações possíveis tenderia a prolongar-se por um espaço não disponível. Então, é preciso reafirmar nossa convicção de que cabe aos projetos de Educação Popular, hoje, não a normalização para a libertação adestradora/homogenizadora mas, ao contrário, o reconhecimento das diferenças e a militância na conquista de padrões maiores de cidadania para todos, por diferentes que sejam. E, mais uma vez, é necessária uma mediação entre os discursos/paradigmas idealistas e hipócritas da direita e o azedume e a generalização dos discursos da esquerda, assim como pela miopia dos que ainda veem o mundo assim polarizado. Como mediação, também por dentro desses discursos e dessa condição. Trata-se de implementar, efetivamente, a intenção de fortalecimento de uma sociedade civil para construir hegemonias e definir espaços públicos, mesmo não sendo Estado.

\section{Referências Bibliográficas}

BOSI, Ecléa. Cultura e enraizamento. In: BOSI, Alfredo (org.) Cultura brasileira. São Paulo: Ática, 1987, p. 16-41.

BRANDÃO, Carlos R. A educação como cultura. São Paulo: Brasiliense, 1985.

FISCHER, Nilton B. A história de Rose: classes populares, mulheres e cidadania Petrópolis: Revista de Cultura Vozes, nov./dez. 1992. p. $38-45$.

Mulheres papeleiras: trajetórias e mediações (dos fragmentos do lixo à globalidade da economia). Projeto de pesquisa apresentado no Concurso para Professor Titular em Fundamentos da Educação (DEBAS-FACED-UFRGS). Porto Alegre: março de 1995. 35p. (mimeo)

ROSA, Russel T.D. A Inserção do trabalho de reciclagem do lixo urbano no sistema social de produção como um processo educativo. Oficinas Educacionais: Dessegregação e Heterogênese. Porto Alegre: Programa de Pós-graduação em Educação/UFRGS, set. 1994. 17p. (mimeo).

SADER, Éder \& PAOLI, Maria C. Sobre "classes populares" no pensamento sociológico brasileiro. In: CARDOSO, Ruth (org.). A aventura antropológica. Rio de Janeiro: Paz e Terra, 1986. p.39-69.

SPINK, Mary Jane P. O conceito de representação social na abordagem psicossocial. Rio de Janeiro: Cadernos de Saúde, 9(3): 300-308, jul./set. 1993. 


\section{Das crises e dos desafios}

Nilza da Rosa Silva

No ponto em que nos encontramos, a definição provisória mais englobante que eu proporia da subjetividade é: "o conjunto das condições que torna possível que instâncias individuais e/ou coletivas estejam em posição de emergir como território existencial autorreferencial, em adjacência ou em relação de delimitação com uma alteridade ela mesma subjetiva." GUATTARI

A vida, como um elemento multicomponencial do real, se produz num processo que se faz entrelaçado à constituição do mundo e adjacente a esta. É o processo de objetivação copenetrado ao processo de subjetivação, em que a modificação da exterioridade e a modificação da interioridade se realizam ativa, simultânea e permanentemente sob as sínteses autopoiéticas do inconsciente. Torna-se, assim, tarefa inútil e impossível a demarcação da fronteira entre estas dimensões da subjetividade. Limite este elidido em todos os níveis, em todas as direções, em todos os sentidos, pelo desejo que, como fluxo mutante desterritorializante, tende a sair - do sujeito, da linha, do assunto, do codificado - a derivar, produzindo novos territórios.

Com tais considerações preliminares, apresento um resumo da análise de elos semióticos, que intercedem na dimensão processual da subjetividade, partindo do discurso e do repertório conceitual, perceptivo e afetivo de quatro pessoas aposentadas, com idades entre 56 a 69 anos, em Porto Alegre, no período de 1992 a 1993.

Utilizando o método cartográfico da esquizo-análise — cujo conjunto teórico provisório aproveita todas as oportunidades de fazer funcionar todo o acontecimento como desvelador do processo de subjetivação, de modo a tornar possível a reapropriação pelo desejo dos meios de produção da subjetividade - questionam-se: Com o que e como se conectam os acontecimentos para funcionarem? Quais pedagogias produzem os repertórios? Como se compõem as territorialidades histórico-geográfico- existenciais? Que linhas e movimentos criam e/ou mobilizam os universos de referência existenciais/enunciativos/incorporais?

Fábio, Ester, Antônia e João, entre 1992 e 1993, participam de grupos diversificados que, enquanto agenciamentos (e por isso mesmo em conexão com outros agenciamentos), fazem uma espécie de organismo, de totalidade e que, simultaneamente, desfazem este mesmo organismo em multiplicidades.

Recorto aqui algumas experiências de vida, relatadas por cada um, como traços de intensidade que implicam num certo estado substantivo dos enunciados.

\section{Do processo de subjetivação}

O processo de subjetivação tem funcionamento rizomático - isto é, comparável a um rizoma - sob mais variadas funções, maneiras, extensão, componentes, movimentos, fluxos, sínteses.

Os elos semióticos - linguísticos, perceptivos, mímicos, gestuais, econômicos, urbanísticos, pedagógicos — as organizações de poder, as ocorrências científicas, as lutas sociais em conexão com a micropolítica do campo social (que me foram sendo desvelados por Fábio, Ester, Antônia e João) foram analisados sob quatro caracteres do funcionamento rizomático: 1) multiplicidade; 2) heterogeneidade; 3) cartografia e 4) ruptura assignificante.

Pela multiplicidade rizomática no processo de subjetivação, as linhas de fuga - as saídas realizadas - engrenando-se umas às outras, produzem dimensões, determinações e grandezas que mudam necessariamente de natureza à medida que aumentam suas conexões. Ao mesmo tempo, também se realizam linhas de segmentaridade (linhas de integração) pelas quais se efetuam as estratificações, a reterritorialização, a organização, a significação (que dá poder ao significante), as atribuições (que reconstituem um sujeito ou um objeto). Fábio, Ester, Antônia e João se inscrevem em diferentes relações de produção, formações de poder, disciplinas capilares e nem tanto, núcleos de parentesco, de aliança, de convivência, locais de moradia e de trabalho, cartografando o corpo pelo exterior. $\mathrm{O}$ universo referendal do corpo foi e continua sendo o trabalho. Através do trabalho 
acrescenta-se, alarga-se o território geográfico-histórico-existencial de cada um por desterritorialização, quebrando o instituído por linhas de fuga instituintes, mas, por segmentarização, estratificando e reterritorializando por linhas de integração. Mas sempre corpo-máquina.

Em Fábio, o corpo, conectado com a terra (um minifúndio), seus ciclos de produção, seus ritmos, sua sazonalidade, sua superfície de registro, seu consumo material e energético (que é também produção da produção), torna-se instrumento de produção/reprodução e objeto parcial de máquinas cada vez mais sofisticadas e precisas da indústria metalúrgica. Inicia seu devir-urbano, quando se processam simultaneamente quatro pedagogias principais: 1) fazer metalúrgico de uma linha de montagem; 2) trabalho assalariado; 3) língua portuguesa rebatida sobre o dialeto de origem; 4) vida conjugal e paternidade. Durante o processo de metropolização, que se faz há 43 anos, o corpo se torna suporte do desejo criador de máquinas simples, baratas, eficientes, engendradas durante as horas de lazer, nos diagramas que antecedem à montagem, desenhadas nas fibras nervosas do córtex cerebral e derramados sobre a mesa de desenho rudimentar. Máquinas submetidas aos maquinismos econômicos que as viabilizam ou não.

Em Ester, o corpo, disjunto da terra natal, acrescenta por desterritorialização outro território, ao qual se conecta na pedagogia do devir-imigrante naturalizado. Inicia, em Porto Alegre, seu processo de metropolização com, simultaneamente, seis pedagogias principais: 1) fazer de professora de rede pública de ensino; 2) burocracia estatal; (3) trabalho assalariado; (4) língua portuguesa rebatida sobre a língua de origem; (5) imigrante; (6) vida conjugal e maternidade. Corpo, instrumento de produção/reprodução e objeto parcial da burocracia do Poder Executivo e suporte do desejo criador de roteiros turísticos, traçados desde as fibras nervosas do córtex cerebral e estendidos sobre os mapas, os orçamentos, as programações e os procedimentos organizativos. Viagens submetidas aos maquinismos econômicos que os viabilizam ou não.

Em Antônia, o corpo, conectado à produção de consumo da terra (um latifúndio), torna-se instrumento de produção/reprodução e objeto parcial da burocracia do Poder Judiciário para a aplicação dos instrumentos legais às ações humanas. Seu processo de metropolização se faz há 39 anos, quando simultaneamente iniciam-se quatro pedagogias principais: 1) formação acadêmica; 2) exercício de profissão liberal; 3) burocracia estatal; 4) vida conjugal e maternidade. Corpo que se torna também suporte do desejo criador de versos enunciados desde as fibras nervosas do córtex cerebral e compostos sobre o papel, versos escritos primeiramente à mão. Enunciações cujas dimensões de alcance estão submetidas aos maquinismos econômicos que as viabilizam ou não.

Em João, o corpo, conectado à fábrica, seus ritmos, sua escalada de produzir por produzir (antiprodução), sua superfície de registro, seu consumo material e energético, torna-se instrumento de produção/reprodução e objeto parcial — como Fábio - de máquinas cada vez mais sofisticadas e precisas da indústria petroquímica. Nascido em Porto Alegre, seu processo de metropolização é simultâneo ao seu processo de vida, com as inúmeras pedagogias implicadas. Corpo também suporte do desejo criador de empresas comerciais, engendradas nas fibras nervosas do córtex cerebral e estruturadas através de dispositivos físicos, jurídicos e relacionais. Empreendimentos submetidos aos maquinismos econômicos que os viabilizam ou não.

Pela heterogeneidade rizomática no processo de subjetivação, os elos semióticos de qualquer natureza são conectados a modos de codificação muito diversos. Para essa multiplicidade de conexões, que informam a heterogênese das sínteses, concorrem também as línguas, os dialetos, as gírias, o jargão, com o que se produzem as falas, os discursos, os enunciados, as enunciações. O movimento, as velocidades, as trajetórias e os deslocamentos desses fluxos se realizam por imigração, êxodo rural, linhas rodoviárias, linhas ferroviárias, rotas turísticas, linhas fluviais, organizações de poder e midiáticas, lutas sociais, industrialização, linhas marítimas. Pulveriza-se assim, a ideia de domínio universal do significante e historiciza-se a hegemonia de uma língua, sua tomada de poder. A análise da linguagem carece, portanto, do seu descentramento sobre outras dimensões e outros registros. Neste processo, as linhas de fuga e/ou as linhas de integração se constroem permanentemente, sem fixar uma extremidade, uma ordem, já que qualquer ponto desse processo pode e deve estar conectado com qualquer outro ponto.

Em Fábio e Ester, o sotaque acentuado e/ou a miscigenação linguística constitui-se índices de resistência e/ou de despotencialização da língua de origem, pela tomada de poder da língua portuguesa. 
Em Antônia e João, o jargão reterritorializa as relações de produção, de distribuição e de consumo, implicando na segmentarização e atribuições

Em todos eles, os elos semióticos cartografam a heterogeneidade do processo.

Pela cartografia rizomática, o processo de subjetivação traça um mapa aberto, conectável em todas as suas dimensões, todos os seus níveis, todas as suas direções e todos os seus sentidos, desmontável, transformável, inteiramente voltado sobre uma experimentação sobre o real.

Pode-se desenhá-lo sobre uma parede, concebê-lo como uma obra de arte, construí-lo como uma ação política ou como uma meditação. (Deleuze, Guattari, 1989, p. 20)

Este processo é estranho a toda a ideia de eixo genético (no qual se organizam os estágios sucessivos filo e ontogenéticos) e de estrutura profunda (no qual se invocam as essências que constituem a identidade e o sujeito), universalizados e unificados e, por isso, reproduzíveis ao infinito.

O devir-metropolitano, em Fábio, Ester, Antônia e João se produz numa dura e fascinante pedagogia, na qual a simultaneidade dos processos, a rapidez dos fluxos de produção, de distribuição e de consumo, a aridez dos processos de segmentarização imprimem à existência a marca do desgaste, da perda, da exaustão, da obsolescência (obsolescência programada da antiprodução?), vividas etapisticamente. Assim, o desejo é capturado pelas máquinas abstratas (maquinismos), as que são regidas pela lógica do capital, como superfície encantada de inscrição da produção, da vida, do mundo e como movimento objetivo aparente, gerador de todas as coisas, a quase-causa.

Fábio, Ester, Antônia e João funcionam dentro das atribuições matrizadas principalmente pelo gênero, classe, estrato socioeconômico, idade. É o estabelecimento da competência.

Pela ruptura assignificante rizomática, a aposentadoria de Fábio, Ester, Antônia e João concretiza a perda de consistência de vários agenciamentos, como a fábrica, a escola, o escritório, os colegas de trabalho, as organizações classistas, os sindicatos, o recorte e a estratificação das horas do dia e/ou da noite. São dentro desses agenciamentos que funcionam diretamente os agenciamentos coletivos de enunciação. Pela aposentadoria realiza-se a perda de consistência dos universos de referências públicos. Mobilizam-se novos universos de referência existenciais e/ou enunciativos e/ou incorporais, onde todos os campos de possíveis se abrem para o mundo privado. Fábio, Ester, Antônia e João executam ou não um movimento de resistência.

Fábio não se sente atraído pelo mundo privado e sobre o qual sua mulher exerce o pleno domínio. Correlação desvantajosa para ele que, no âmbito público, consegue relativa autonomia. Limitado por atribuições e estratificações, ele reterritorializa suas ações sobre o cultivo do quintal (uma horta), a reforma e ampliação da casa e a prestação de serviços aos filhos e ao neto. Mas é território de esgotamento rápido. Suas incursões sobre o espaço das atribuições ditas femininas produzem embates frequentes com a mulher que intensifica e amplia seu território privado o mais que pode, impulsionada pela perda de consistência do universo familiar, que se dá com a saída dos filhos para constituírem os seus próprios universos familiares. Território pequeno para o investimento de ambos. Zonas de atrito, de aprisionamento e de mágoas criam-se em torno de tarefas cotidianas, nas quais os excessos de economia, de desperdício, de cuidado, de esmero e de dedicação se sobrecodificam como mesquinharia, falta de zelo, perda de tempo e sufocamento.

Ester, resistindo a reterritorialização sobre a moradia e seu cotidiano de solidão, realiza linhas de fuga para o exterior da casa, para o interior do trabalho, para o interior da família ascendente (viagens, volta ao trabalho remunerado, visita a parentes), desinvestindo do seu âmbito particular.

Antônia oscila ainda entre os dois mundos, sobrecodifica-se avó, com todas as atribuições do cargo e o estende à esfera pública no eixo da caridade.

João, tal como Fábio, realiza um investimento fragmentado na esfera privada, na qual se sente intruso, mundo do qual esteve ausente grande parte do tempo. Revela-se inútil a tentativa de organização e de hierarquização desse espaço e seus fluxos à sua imagem e semelhança. Extraído de um universo de referência público, não consegue intervir no universo de referência privado, pleno dos filhos adolescentes e da mulher. E se mobilizam afetos de sofrimento.

Os desafios colocados às quatro pessoas - e nem sempre sustentados por elas — movimentam eixos imanentes entre si: 1) rupturas 
autonomizantes; 2) ressignificação da vida; 3) criação de novos universos de referência e novas modalidades de subjetivação singularizantes. Tais desafios estendidos também aos pesquisadores e/ou animadores de grupo e nem sempre sustentados por eles — requerem a tenacidade e a delicadeza que a reinvenção do cotidiano exige.

\section{Referências Bibliográficas}

DELEUZE, Gilles, GUATIARI, Félix. Mille Plateaux. Capitalisme et Schizophrénie. Paris: Les Éditions de Minuit, 1989. \& Alvim, s.d. O Anti-Édipo. Capitalismo e Esquizofrenia. Lisboa: Assirio

GUATARRI, Félix. Caosmose. Um novo paradigma estético. Rio de Janeiro: Edições 34, 1992.

\section{Ser mulher, ser homem: significações construídas por crianças de classes populares}

Nara M.G. Bernardes PUCRS

Helena Beatriz Scarparo PUCRS

Ana Helena P. do Amarante PUCRS

Volnei S. Matias PUCRS

\section{Introdução}

Este trabalho ${ }^{1}$ examina aspectos das imagens de ser mulher/ser homem construídas por crianças negras e não negras de classes populares, focalizando-as na perspectiva das relações de gênero.

O gênero, como um conceito teórico, tenta dar conta da construção social do sexo, apontando para o caráter relacional e histórico desse processo (Joan Scott, 1990). Ele questiona a naturalização das características definidas sócio-culturalmente como femininas ou masculinas e coloca novos desafios para o estudo de temas da Psicologia Social que aparentemente já estariam esgotados em sua compreensão, como por exemplo, as imagens sobre mulheres e homens presentes em nossa realidade social. Não se trata apenas de identificar semelhanças ou diferenças entre homens e mulheres mas de entendê-las como produtos das relações de desigualdade (gênero, raça/etnia, classe social, idade) que constituem a sociedade (Nara Bernardes, 1993).

Constituído por e constituinte de relações sociais, o gênero manifesta-se nos símbolos culturais, nos conceitos normativos, na política,

${ }^{1}$ Este trabalho foi desenvolvido pelo Grupo de Estudo de Educação, Subjetividade e Gênero, coordenado pela Profa. Nara M. G. Bernardes, o qual tem recebido apoio do CNPq, da FAPERGS e da PUCRS. 
nas instituições e organizações sociais e nas identidades subjetivas (Joan Scott, 1990).

As subjetividades femininas ou masculinas entendidas como o modo próprio de o ser humano se pôr e se expressar no mundo (Hanna Arendt, 1989) apresentam configurações múltiplas numa mesma sociedade. Isto porque o desenvolvimento do gênero de homens e mulheres é um processo que envolve não só recepção passiva mas também resposta ativa às situações conflituosas (Jean Anyon, 1990). Ao se defrontarem com expectativas sociais e culturais que são divergentes, opostas, mulheres e homens são capazes de aceitar, de adaptar-se ou de negar, de transformar, são, portanto, capazes de acomodações e de resistências em diferentes planos (subjetivo, intersubjetivo e coletivo). As construções de sujeitos masculinos e femininos "se fazem de acordo com diferentes modelos, ideais, imagens que têm as diferentes classes sociais, raças, religiões, etc. sobre mulher e sobre homem" (Dagmar Meyer, Guacira Louro, 1993, p.3).

O presente estudo buscou compreender como se mostravam as imagens de ser mulher/ser homem em crianças (de 9 a 12 anos de idade) negras e não negras, pertencentes a segmentos das classes populares que habitam a periferia urbana da região metropolitana de Porto Alegre (RS). Essas crianças pertenciam a grupos familiares que se organizavam de forma diversificada: família conjugal, família conjugal recomposta e família chefiada por mulher. Eram moradores da mesma vila e frequentavam a mesma escola de primeiro grau (na terceira e quarta série).

Tendo como ponto de partida empírico a experiência vivida desses sujeitos foram estudadas, por meio de uma análise compreensiva de base fenomenológica, as vivências e significações de um grupo de 28 crianças, bem como de adultos significativos que fazem parte de seu mundo da vida (mãe, pai, outros familiares, professoras). Os dados foram coletados em 1987.

\section{Desvelamento das imagens}

A análise das vivências e significações permitiu captar imagens do ser mulher/ser homem que estão sendo construídas por essas crianças e que envolvem múltiplas esferas de experiência: família, trabalho no espaço doméstico, trabalho e movimento em outros espaços.

\section{Família}

A família foi focalizada pelas crianças no âmbito da relação conjugal, entendida como uma situação de convivência mais permanente, independentemente de existirem vínculos legais entre os cônjuges. Ela implica relações de poder e relações de amor.

A maioria das crianças considera que o esposo e a esposa devem obediência mútua, de forma idêntica. A obediência, contudo, não é incondicional mas depende de a ação ser considerada correta.

Algumas das ações que são avaliadas como corretas são:

- quando um dos cônjuges ausenta-se da casa deve avisar ao outro para evitar preocupações, embora não seja necessário pedir autorização para fazê-lo;

- se a esposa discorda de decisões do esposo está dispensada de seguir suas determinações;

- a esposa deve exigir que o esposo se responsabilize pelo sustento da casa mesmo que este não queira trabalhar e deseje que ela assuma tal responsabilidade;

- o esposo deve insistir para que sua esposa exerça um trabalho remunerado quando isto for necessário, mesmo que ela não o deseje;

- a esposa deve exigir que o esposo realize suas obrigações nos serviços da casa.

- o esposo deve chamar atenção de sua esposa quando esta realiza ações inconvenientes, tais como fazer compras supérfluas;

- o esposo deve obedecer sua esposa porque ela também possui autoridade na família;

- os desejos da esposa durante a gravidez devem ser atendidos;

Entre as ações do esposo que são consideradas incorretas e que, portanto, não devem ser obedecidas destacam-se:

- não permitir que a esposa conviva com pessoas externas à família como amigas, parentes, exigindo que ela permaneça em casa;

- mandar excessivamente na esposa como se fosse seu pai; 
- determinar que a esposa faça algo para o qual ela julga-se inepta;

- não permitir que a esposa trabalhe fora de casa; doméstico;

- cercear a circulação da esposa em outros espaços que não o

- determinar uma carga excessiva de serviços da casa para a esposa executar.

Algumas meninas, entretanto, acentuam que, em geral, a autoridade do esposo é mais saliente uma vez que nem todos os homens aceitam obedecer à mulher. Além disso, quando a esposa faz alguma ação avaliada como errada, o esposo julga-se no direito de chamar-lhe atenção.

A ideia da ação correta também aparece na reciprocidade do exercício do poder entre os cônjuges. Um menino não negro de família chefiada por mulher, por exemplo, considera que a esposa só deve aceitar determinações do esposo que ela julgar corretas e que este, por sua vez, deve também obedecê-la nas mesmas condições.

Divergindo desses sujeitos que consideram que a obediência na relação conjugal deve ser mútua, poucas crianças não negras afirmam que o esposo deve possuir maior poder e exercer maior autoridade do que sua esposa. Esta ideia mostra-se acompanhada das seguintes explicações:

- o esposo deve ter mais liberdade e não pode admitir a interferência de sua esposa a não ser quando se trata de alguma ação que venha a prejudicá-lo;

- o esposo tem mais competência para mandar em virtude de ser pai e dono da casa;

- a esposa deve obedecer para evitar o conflito;

- a esposa deve cumprir as determinações de seu esposo em relação aos serviços domésticos, uma vez que permanece mais tempo em casa do que ele;

Entre essas crianças não negras que consideram que a posse do poder e o exercício da autoridade são próprios do esposo, os meninos apresentam certa ambiguidade ao mencionarem algumas possibilidades eventuais de a esposa também compartilhar de tais atributos:
- em assuntos nos quais ela tem razão;

- no que concerne ao cuidado das crianças;

- para evitar que o esposo tenha prejuízos econômico-financeiros.

Numa posição diferente das anteriores, as crianças pertencentes a famílias chefiadas por mulher, por sua vez, acham que nem a esposa nem o esposo devem obediência mútua uma vez que são pessoas independentes e nenhum tem poder sobre o/a outro/a.

Essas significações mostram que as relações de poder entre homens e mulheres quando visualizadas na situação de uma união (legal ou consensual) mais permanente, são percebidas pela grande maioria das crianças (independentemente do gênero, raça ou tipo de família) como sendo igualitárias. Raras crianças consideram legítima a assimetria entre os gêneros, atribuindo maior poder/autoridade ao homem.

No que tange às relações de amor na família, algumas crianças não negras consideram que a convivência entre os cônjuges deve caracterizar-se pelo amor e pelo carinho. Outras crianças não negras bem como os meninos e as meninas negros/as agregam o respeito ao amor e ao carinho. Este se define pela negatividade e se expressa em ações que são comuns a ambos os cônjuges: não brigar, não se irritar, não maltratar, não repreender, não envolver-se com outro homem ou outra mulher. Aparece apenas uma ação específica do esposo: não beber. A necessidade do respeito, portanto, mostra padrão semelhante para a mulher e o homem pois inclui a negação de ações relativas à agressividade, à violência, ao controle e à infidelidade. O padrão masculino de respeito inclui, também, a negação do alcoolismo que parece ser mais comum à conduta dos homens.

Um menino de família conjugal recomposta acentua que o tratamento carinhoso e respeitoso da esposa em relação ao seu esposo requer reciprocidade.

Atributos associados à família colocam o homem em posição de vantagem quando este é avaliado comparativamente à mulher. Algumas crianças (meninas e meninos) não negras destacam que o homem:

- é mais capaz de cuidar da mulher e dos filhos; 
- representa um valor muito significativo para seus filhos, sua esposa e sua própria mãe.

Ao contrário, outros meninos não negros assim como meninas negras e não negras apontam vantagens da mulher:

- garante a reprodução dos homens e das mulheres;

- é capaz de assumir o cuidado e a educação das crianças.

A este respeito, um dos meninos (de família conjugal recomposta) chama atenção também para uma desvantagem da mulher que consiste na possibilidade de engravidar e ter de assumir sozinha a responsabilidade pelo/a filho/a no caso de o pai da criança não permanecer junto a ela.

\section{Trabalho no espaço doméstico}

Entendemos por trabalho no espaço doméstico atividades que se realizam de modo gratuito e isolado na privacidade da casa para manter a vida e promover o bem estar da família. Para as crianças, a responsabilidade por esse trabalho que engloba as atividades consideradas serviço da casa (limpeza, arrumação do espaço interior da casa ou do pátio, alimentação e higiene pessoal do membros da família) é essencialmente atribuída à mulher. Tal significação, contudo, não impede que a participação dos homens nessas tarefas, particularmente dos meninos, seja vista como adequada à conduta masculina. Apenas poucos meninos não negros de família conjugal entendem que tais tarefas são impróprias para os homens executarem.

De modo geral, as crianças valorizam a competência do homem para realizar tarefas atribuídas à mulher, especialmente em situações em que esta (adulta, adolescente ou criança) encontra-se ausente porque exerce um trabalho remunerado fora de casa; ou ainda, em situações emergenciais, por exemplo, devido à doença da mulher, ao puerpério. No cotidiano dessas famílias de classes populares não se encontra a figura da empregada doméstica que executa e, às vezes, até se responsabiliza por tais tarefas.

Para as crianças, a responsabilidade pelo trabalho no espaço doméstico passa a ser atribuição do homem quando se trata de tarefas que se destinam à conservação da casa e/ ou de seus equipamentos por meio de consertos diversos; ela se revela de modo especial em relação à construção da casa. Tais atividades são percebidas como um trabalho que foge da rotina e requer habilidades culturalmente consideradas como masculinas, inclusive porque algumas exigem mais força física.

Um dos trabalhos no espaço doméstico que raramente pode ser fracionado ou postergado - cuidar das crianças e dos idosos é considerado uma atribuição mais específica da mulher, seja ela adulta, adolescente ou criança. Nas sociedades capitalistas operou-se uma distinção mais nítida entre a produção de bens materiais e a reprodução de seres humanos. Os vínculos imediatos e diretos que a maternidade estabelece com os cuidados indispensáveis à sobrevivência do bebê são pensados como sendo naturais. Tais vínculos ampliam-se de forma a englobar tarefas que se destinam à manutenção (física e psicológica) e à educação das crianças durante seu desenvolvimento posterior. A atribuição histórica e cultural de tais tarefas ao gênero feminino perpassa raças e classes sociais, quer as próprias mulheres tenham gerado as crianças, quer estejam com as crianças por delegação de que as gerou.

\section{Trabalho em outros espaços}

$\mathrm{O}$ trabalho em outros espaços inclui o trabalho remunerado e realizações. As significações apresentadas pelas crianças demonstram uniformidades mas também ambiguidades.

A maioria das crianças aponta o trabalho remunerado como um dos valores mais relevantes na vida do homem e, também, da mulher. No caso do homem, esta valorização parece ser tácita uma vez que essas crianças não se preocupam em justificá-la. Em se tratando da mulher, contudo, algumas meninas e alguns meninos oferecem explicações:

- garante maior consumo para os filhos;

- permite um cuidado melhor da saúde dos filhos;

- permite buscar o atendimento dos interesses da mulher bem como a conquista do que deseja;

- garante a sobrevivência da família. Esta ideia foi expressada por uma menina e um menino cujas famílias são mantidas, basicamente, por meio do trabalho assalariado da mãe.

Tais significações, contudo, não impedem que, de modo geral, o trabalho remunerado da mulher seja concebido pelas crianças como sendo 
essencialmente uma ajuda ou colaboração prestada ao homem na sua função de responsável pela manutenção econômico-financeira da casa e da família.

Atributos concernentes ao trabalho em outros espaços colocam o homem em posição de vantagem em relação à mulher, conforme as significações construídas por crianças não negras (meninas e meninos) bem como por meninos negros:

- saber e saber fazer;

- ter acesso mais fácil ao mercado de trabalho à medida que é capaz de fazer trabalhos mais diversificados;

- não sofrer restrições no trabalho em decorrência da maternidade;

- poder ter uma profissão;

- trabalhar menos do que a mulher porque esta trabalha também em casa;

- trabalhar menos porque pode mandar outros executarem as tarefas;

- saber mandar;

- ser mais capaz de construir e inventar objetos;

- ter maior acesso a cargos de poder tanto políticos como profissionais.

Por outro lado, algumas crianças negras e não negras salientam atributos também concernentes ao trabalho em outros espaços os quais favorecem à mulher:

- ser mais esperta que o homem;

- saber pensar e argumentar melhor que o homem;

- ser mais capaz e ter mais habilidades do que o homem porque realiza atividades mais diversificadas (trabalha fora de casa, faz os serviços domésticos, cuida de crianças);

- poder ter uma profissão e trabalhar;

- realizar trabalhos mais leves e que exigem menos esforço.

Movimento em outros espaços
O movimento em outros espaços que não o doméstico consiste em sair dos limites da casa para circular, em lugares variados de trabalho e lazer, sem estar sob controle de outros.

Alguns meninos (família conjugal recomposta ou chefiada por mulher) bem como algumas meninas de família conjugal assinalam atributos ligados ao movimento em outros espaços, os quais colocam a mulher em posição de vantagem ou, pelo menos, de igualdade em relação ao homem:

- a mulher é independente e não necessita do homem para realizar seus desejos;

- corre menor risco de criar problemas para si, praticando ações socialmente indesejáveis;

- é capaz de se defender;

- tanto quanto o homem, a mulher possui liberdade.

Uma das meninas, por exemplo, enfatiza como um dos valores mais significativos na vida da mulher sua capacidade para defender-se e tomar conta de si, mesmo quando sozinha.

Ao contrário, outros meninos negros e não negros assim como outras meninas não negras chamam a atenção para condições que colocam o homem em posição de vantagem em relação à mulher:

- sabe defender-se melhor quando agredido na rua;

- pode ser mais independente em espaços diversos;

- sofre menor controle da família para movimentar-se em espaços que não o doméstico para atender a seus interesses;

- tem maior acesso ao lúdico fora do espaço doméstico;

- não necessita da permissão da mulher para fazer o que deseja;

- tem maiores possibilidades de satisfazer seus desejos;

- pode namorar mais precocemente e com mais intensidade;

Para algumas meninas, inclusive, a liberdade de movimentar-se em espaços diversos, sua capacidade para se defender no mundo e para afastar- 
se de casa sem precisar de ajuda consistem em valores muito significativos na vida dos homens.

Ao mesmo tempo, alguns desses meninos e essas meninas consideram a mulher mais incompetente, irresponsável ou sujeita a correr riscos quando está fora de sua casa. Uma das meninas, por exemplo, aponta a necessidade de a mulher cuidar-se e não se envolver com pessoas estranhas.

Representam exceções os poucos meninos para os quais tanto a mulher quanto o homem têm as mesmas possibilidades de ser livres no seu movimento em quaisquer espaços.

\section{Identificação com o gênero}

As meninas negras e poucas meninas não negras expressaram uma valorização muito nítida da mulher e foram enfáticas ao afirmarem o desejo de permanecerem mulher quando confrontadas com a possibilidade imaginária de nascerem novamente. Essa valorização diz respeito à esfera do trabalho no espaço doméstico e em outros espaços, como o do trabalho remunerado, à sua inteligência e competência para cuidar de si e às suas possibilidades de movimentar-se em espaços diversos.

Juntamente com os meninos negros e algumas crianças não negras, essas meninas negras repudiam qualquer relação de dominação entre homens e mulheres. Por outro lado, a concepção de ser mulher/ser homem dos meninos negros não se revela tão polarizada como em outras crianças, principalmente, em outros meninos.

Os meninos negros pertencem a famílias chefiadas por mulher. Esta modalidade de organização familiar não é restrita, mas faz parte do modo de as pessoas negras se constituírem como grupo social. Entre as famílias chefiadas por mulher aparece a família formada por pessoas agregadas que, às vezes, não possuem laços de parentesco ou este parentesco é distante. Nesta pesquisa, as famílias negras chefiadas por mulher caracterizavam-se por serem formadas por duas mulheres adultas e por incluírem pessoas sem laços de parentesco com elas, como adolescentes ou crianças adotadas (mesmo que por meios informais). Apesar de viverem em condições financeiras precárias (renda familiar mensal inferior a dois salários mínimos), essas mulheres exibiam um sentimento muito forte de solidariedade e de responsabilidade em relação a crianças que não foram geradas por elas. Neste aspecto diferem das famílias chefiadas por mulher não negras cujo modo de organização resultou da separação do casal ou da viuvez e que, embora morando na mesma casa ou no mesmo terreno do pai ou do sogro, entendem que sua família é formada por ela e seus filhos ou filhas.

Entre as crianças negras deste estudo, portanto, a figura feminina mostra uma presença marcante e se constitui num ponto de referência.

A maioria das meninas não negras mostrou uma postura oposta à das outras meninas não negras bem como das meninas negras que desejam permanecer mulher. Confrontadas com o ser mulher/ser homem que se constituem de modo assimétrico no sentido da valorização do homem, a maioria das meninas não negras manifestou o desejo de nascer homem caso isso pudesse ocorrer novamente. $\mathrm{O}$ cerne desta valorização, que se apresenta ou de forma muito explícita ou carregada de ambiguidades, diz respeito às possibilidades, à competência e à legitimidade para sair dos limites do espaço doméstico para outros espaços, por exemplo, para o mundo da rua. Essas meninas que desejariam mudar de gênero, mesmo que imaginariamente, visualizam o homem como alguém que possui maior liberdade e independência do que a mulher para movimentar-se em quaisquer espaços.

Tomando como referência, igualmente, as significações que atribuem ao ser homem uma valorização mais positiva do que ao ser mulher em diferentes esferas de experiência, os meninos, sem exceção, preferem continuar sendo homens. Explicitam, assim, uma identificação menos ambígua com seu gênero ao mesmo tempo em que assinalam claramente as assimetrias entre homens e mulheres.

Em suma, o desvelamento das imagens do ser mulher/ser homem de crianças negras e não negras de classes populares, sujeitos desta investigação, revela um universo complexo e múltiplo de significações que formam uma rede na qual aparecem uniformidades e consistências mas também variações e ambiguidades. A construção dessas subjetividades não se dá como um processo linear e homogêneo que pode ser generalizado de modo essencialista em identidade de homem ou de mulher. Ao contrário, tais imagens apontam múltiplas possibilidades de tecer significações que constituem subjetividades singulares nas diferentes articulações do gênero, da raça/etnia e da classe social. 
Referências Bibliográficas

ANYON, Jean. Intersecções de gênero e classe: acomodação e resistência de mulheres e meninas às ideologias de papéis sexuais. Cadernos de Pesquisa, São Paulo, n. 73, p. 25-47, maio 1990.

ARENDT, Hanna. A condição humana. $4^{\mathrm{a}}$ ed. Rio de Janeiro: Forense Universitária, 1989.

BERNARDES, Nara M. G. Autonomia/submissão do sujeito e identidade de gênero. Cadernos de Pesquisa, São Paulo, n.85, p. 43-53, maio 1993.

MEYER, Dagmar, LOURO, Guacira A escolarização do doméstico. A construção de uma escola técnica feminina (1946-1970). [1993]. Mimeo gr.

SCOTT, Joan. Gênero, uma categoria útil de análise histórica. Educação \& Realidade. Porto Alegre, v.16, n.2, p. 5-22, jul./dez 1990.

\section{Anotações sobre ética, movimentos sociais, pesquisas}

Petronilha Beatriz Gonçalves e Silva

UFSCar

$\mathrm{O}$ interesse de pesquisadores pelos movimentos sociais tem sido despertado pela busca de compreensão das ações humanas na construção das sociedades, pela simpatia por lutas destes movimentos, pelo engajamento em algumas delas. O curso de suas investigações é marcado, entre outras determinações e decisões, pela postura dos investigadores frente ao objeto de estudos, bem como aos integrantes dos grupos que criam condições para que possam decifrar o processo de enfrentamento entre sociedade e movimento social. Sobre esta problemática, pretendo, com algumas anotações, participar da discussão de tão importante questão de ordem ética.

Os movimentos sociais surgem de necessidades humanas não atendidas: terra, moradia, saúde, educação, respeito, cidadania. Todos eles lutam pela dignidade dos seres humanos, considerados, estes, nas suas diferenças, que são definidas por características étnicas, culturais, físicas, de comportamentos, de costumes, de escolhas, de participação na produção de bens. Lutam para que todos tenham liberdade de viver e de agir. Suas determinações, metas e ações assinalam que a liberdade buscada se constrói nas relações entre indivíduos, grupos e classe sociais, no interior da sociedade que os classifica conforme critérios e interesses ditados pelos que detêm o poder de governar.

Na luta vão tomando mais clara a consciência da realidade em que vivem. Dizendo de outra forma, com suas ações explicitam sua situação na sociedade, e esta com suas respostas indica o lugar que lhes reserva, como os situa. Assim, os índios reivindicam a posse das terras que tiveram usurpadas; os descendentes de africanos combatem o racismo e exigem reconhecimentos da decisiva participação dos seus antepassados escravizados e da sua própria na construção da nação brasileira; os camponeses destituídos de suas terras e os sem-teto nas zonas urbanas fazem propostas e exigências; os homossexuais exigem reconhecimento às suas escolhas sexuais; todos afirmam a importância de serem respeitados enquanto seres humanos, que reivindicam direito a uma cidadania negada. 
Diante das ações dos movimentos sociais, a sociedade reage, deixando, quase sempre mais evidente o lugar que destina aos por eles defendidos: à margem, fora do alcance dos direitos civis. A sociedade reconhece que são diferentes do que ela elegeu considerar humano, correto, bom e designa-lhes, numa atitude discriminatória, como povo, marginalizados, negros, pobres, primitivos, incapazes, doentes, portadores de desvios de comportamentos. Faz-lhes concessões, restrições, julgando na maior parte das oportunidades suas ações como inconvenientes.

A sociedade os exclui, os vê como estranhos, os humilha, ultraja e, desta forma, os impede de usufruir plenamente de seus direitos de cidadãos.

A exclusão que a sociedade faz dos grupos considerados minoritários, embora até mesmo sejam maioria numérica - é o caso, por exemplo, das mulheres que compõem mais de $50 \%$ da população brasileira e dos pretos e pardos que constituem em torno de $60 \%$ desta população aproxima os movimentos sociais em sua luta, embora o motivo primeiro de cada um difira. Fundamentalmente todos tem em mira justiça, equidade, respeito. Todos rejeitam a opressão, querem ser reconhecidos por seus méritos e não pelas carências, que, diga-se de passagem, eles próprios não cultivam. Todos, com suas ações, mostram que o relacionar-se com o outro, é sempre um momento ético.

Isto faz com que a sociedade seja obrigada a encará-los como outro, vivo, ativo. No entanto, teima em simplesmente tolerar sua presença, já que não pode eliminá-los, embora não deixe de tentar fazê-lo — lembremos as reiteradas tentativas de extermínio que sofrem as populações índia e negra, da chegada dos europeus, no século XVI, aos nossos dias - e busca acordos para acalmá-los, ou absorve algumas de suas produções, traços de suas culturas. É claro que a absorção de dados das culturas das classes que marginaliza, se dá também pelo fato de que grupos culturais diferentes ao se encontrarem, seja numa situação de diálogo ou de opressão, recebem sempre influência um do outro.

A sociedade não busca, pois, compreendê-los como seres humanos distintos (Dussel, s.d.), tolera-os já que as tentativas de eliminá-los não têm sucesso absoluto, reduzindo-os à cor da pele, à condição social. É a partir destas reduções que a sociedade mostra o entendimento que tem dos participantes dos movimentos sociais e daqueles cujos direitos visam a defender. Os significados a eles atribuídos vêm informado por preconceitos e por ideologias como as do racismo, do machismo, da incapacidade dos pobres, que produzem palavras, atitudes, posturas estereotipadas, instrumentos eficazes de violência explícita ou simbólica.

Esta violência é fruto, entre outras coisas, do que Sylvia Winter (1992) denomina distorção cognitiva, isto é, ignorância do que o outro realmente é, melhor dizendo, do que os outros realmente são, pois o outro são muitos, não apenas numericamente, mas em diversidade étnica, de classe, de gênero e também de situação dentro do seu próprio grupo social. É sabido que os grupos sociais não são monolíticos e que, em muitas circunstâncias, vivenciam também nas relações mantidas entre os pares aquelas que suportam no confronto com a sociedade mais ampla. Silva (1990) nos mostra isto, ao discorrer sobre as relações de mulheres negras letradas e não letradas, pertencentes à classe média e classe pobre no interior dos grupos do movimento negro ou do movimento de mulheres descendentes de africanos.

Os movimentos sociais não estão unicamente em busca de bens socioeconômicos. Ao desencadear suas reivindicações pressionam, para que todos, cidadão brasileiros, assumamos nossa história coletiva que tem mais de uma faceta; melhor dizendo, foi e é vivida a partir de diferentes pontos de vista. Pensemos na não coincidência de significados que têm para as classes poderosas, bem como para as desprezadas e sacrificadas, por exemplo, a escravidão, a abolição da escravatura, a colonização europeia e a asiática, as lutas designadas messiânicas como a de Canudos, dos Condestados, dos Mukers. Assim sendo, ao assumir nossa história estaremos criando condições para exercer nossa liberdade, o que implica engajamento na situação em que se encontram nossos grupos étnicos, nossa classe social, os grupos sociais a que nos integramos. Implica, pois, engajamento na ação.

Não engajamento aparente, simplesmente, no caso dos pesquisadores, para fazer nossos estudos. Trata-se de um engajamento que faz ver o outro, melhor dizendo, os outros, não com compaixão, pena, como pessoas a quem vamos caridosamente ajudar, tirar de uma situação de pobreza, humilhação. Trata-se de engajamento em que o outro distinto, na medida do nosso esforço para compreendê-lo, vai mostrando-nos: 
- o que investigar, valendo-nos de critérios que não abrangem unicamente nosso próprio interesse;

- como fazê-lo, para que não deixe de ser respeitada a dignidade, as especificidades dos grupos e das pessoas, todas elas, inclusive as do pesquisador;

- como e para quem devem ser encaminhados os resultados dos estudos que conjuntamente fazemos; ou que fazemos com a sua aquiescência.

Pesquisa seja nos meios populares, seja com grupos populares, entre eles os ligados a movimentos sociais, requer respeito às pessoas com quem trabalhamos, que se manifesta também quando suas posturas, entendimentos, avaliações não coincidem com os nossos. Não se trata de adotarmos suas ideias, opções, iniciativas, ou de concordarmos com tudo o que pensam ou fazem, como também não se trata de adotarem os nossos ou de com eles concordarem.

Então, pesquisadores realizamos trabalhos com e/ou sobre grupos dos movimentos sociais não a partir de representações que deles fazemos previamente, mas de trocas, em que cada um de nós tem a sua palavra a dizer e sua ação a executar.

Mas as questões éticas que surgem do encontro entre pesquisadores e movimentos sociais, com objetivos de investigação, não se restringem ao campo das relações entre pesquisador e pesquisados, entre pesquisador e objeto de investigação. Há outras esferas, dentre as quais gostaria de apontar: a da impregnação da linguagem científica por categorias do interesse dos movimentos sociais e a da globalização das culturas.

Ladriére (1977) assinala que:

hoje, a ciência não é mais simplesmente um método de conhecimento, tampouco apenas um corpo de saberes, é um fenômeno sociocultural de uma imensa amplitude que domina completamente o destino das sociedades modernas.

Interpretando suas palavras, podemos reconhecer que o produzido pelas ciências, entre outros reflexos, constitui-se em fonte de poder daqueles que têm acesso a esta produção. Ora, se os resultados de estudos relativos a grupos sociais são organizados, ignorando as peculiaridades ou desprezando-as, como poderão ser tomadas medidas que visem a realmente suprimir desigualdades que têm gerado a organização dos movimentos sociais? Cada vez se tem mais clareza da importância das categorias classe social, gênero, etnia nas ciências humanas. Quais outras serão do interesse dos movimentos sociais em geral e em particular? Nada mais do que pesquisas, num projeto conjunto com grupos dos movimentos sociais para situá-las e expressá-las.

Esta última afirmativa pode ensejar o entendimento de contraposição aos que entendem serem válidos os resultados de investigações somente se permitirem generalizações, bem como ao que se vem denominando mundialização das culturas, da vida diária. De um lado, isto sim, em se tratando de grupos dos movimentos sociais generalizações precisam ser cuidadosamente questionadas antes de qualquer aplicação. De outro lado, sem desconhecer os efeitos da globalização da economia, tampouco da agilização das comunicações no modo de pensar, de organizar a vida de povos e grupos sociais, convém ressaltar, como pondera Ortiz (1994), a existência cada vez mais difundida de uma cultural internacional não significa abolição das particularidades.

Com estes apontamentos, espero contribuir para que se continuem aprofundando o pensamento, as discussões, as escolhas, os critérios de análise, as motivações que engendram pesquisas junto a grupos dos movimentos sociais.

\section{Referências Bibliográficas}

DUSSEL, E. Para uma Ética da Libertação Latino-Americana. São Paulo: Loyola; Piracicaba: UNIMEP, s.d.

LADRIÈRE, J. Les enjeux de la rationalité. Paris: AubierMontainge/UNESCO,1977.

ORTIZ, R. Mundialização da Cultura. São Paulo: Brasiliense, 1994.

SILVA, P.B.G. e. Organização da Mulheres Negras, Hoje. Revista de Cultura Vozes, Petrópolis, Vozes, 84(2): 220-26.

WINTER, S. Do not call us negros. San Jose, CA: Basic Books, 1992. 


\section{Possíveis intervenções psicossociais em relação aos portadores de fissuras lábio-palatais}

Maria Lucia Tiellet Nunes PUCRS/UFRGS

Marcia Luconi Viana PUCRS/UNISINOS

Fissurado é a expressão que se usa para designar a pessoa portadora de fissura lábio-palatal (Cariola e Ferreira de Sá, 1987). Trata-se de uma "malformação estrutural que resulta de um erro morfogenético localizado" (Hopker, 1984, p.5). As fendas entre o processo nasomedial e os processos nasolaterais que todos os embriões humanos apresentam são normais até a sexta semana de vida. Diversos fatores podem impedir a fusão destes processos, tomando-se a fenda permanente - não se trata de corte ou de destruição, mas de ausência de fusão (Ely, 1980; Tureen e Tureen, 1986); atinge a região das vias aerodigestivas superiores: região anterior da face, boca, lábios, palato mole, palato duro e alvéolos dentários (Cariola e Ferreira de Sá, 1987). Dependendo do processo incompleto de fusão, a malformação pode se apresentar como fissura labial, fissura palatina ou fissura lábio-palatal (Ely, 1980; Borges-Osório e Robinson, 1993).

Trata-se de uma das malformações congênitas mais frequentes: um em cada 600 ou 700 nascimentos (Tureen e Tureen, 1986), ou um em cada 1000 (Ely, 1980; Resende, 1983) apresenta um sintoma desde o nascimento e é um estado de disfunção visível (Hopker, 1984), que pode ser diagnosticado por endoscopia (Rauskolb, 1984) e por ecografia (Hackloer, 1984), já na décima segunda semana de gestação.

Embora as causas de tal malformação ainda sejam discutíveis, segundo Tureen e Tureen (1986), sabe-se que podem estar associadas à mãe (desnutrição, alcoolismo, tumores uterinos, rubéola, etc.) ou à criança (falta de oxigênio durante o desenvolvimento embrionário, movimentos do feto com o dedo ou a mão na cavidade oral, etc.). A hereditariedade tem um papel definitivo, mas nem sempre verificável em muitos dos casos (Ely, 1980; Resende, 1983). Embora alguns estudos apontem para estresse emocional da mãe como possível causa, há pouca evidência para tal (Ely, 1980; Wolkind, 1983).
O nascimento de uma criança com uma mal formação costuma provocar uma crise na família (Tureen e Tureen, 1986) e pode prejudicar o desenvolvimento do vínculo entre mãe-pai-criança, embora este processo não seja bem compreendido até hoje (Klaus e Kennell, 1978). Aceitar um filho malformado requer um longo processo de luto pela perda do bebê idealizado (Solnit e Stark, 1962) e os pais atravessam conflitos que envolvem culpa, desesperança, medo, raiva (Tisza e Gumpertz, 1962). Especialmente, as mães, que estão mais próximas do bebê no seu penado inicial de vida, sentem-se temporariamente inábeis para lidar com seus filhos (Mercer, 1974). Tais sentimentos estão ligados à ideia de a mulher ser responsável por não ter cumprido a função reprodutora, prevista pela sociedade, de gerar crianças belas e perfeitas (Viana, Giacomoni e Rashid, 1994) As mães, então, se perguntam porque mereceram tal castigo (Viana, 1992).

Além destes sentimentos, no início, os pais se preocupam com a sobrevivência do bebê: como alimentá-lo, como se portar em relação às cirurgias funcionais e reparadoras; depois, a preocupação estará centrada na dentição, na fala, na aprendizagem e no desenvolvimento social da criança (Amaral, 1986). Apesar disso tudo, estes pais não devem ser vistos como fundamentalmente diferentes de quaisquer outros pais (McWilliams, 1982).

Certamente malformações congênitas são mobilizadoras de sentimentos intensos tanto nos seus portadores como naqueles que com eles convivem. Uma sociedade que tenha como grande valor a beleza e a perfeição físicas agravará a maneira como tais malformações são vivenciadas por seus portadores e percebidas pelos outros. E, muitas vezes, pessoas que possuem um atributo que é visto como perturbador são estigmatizados por causa de tal característica (Goffman, 1982). Assim, embora pesquisas apontem para a inexistência de uma personalidade de fissurado e mostrem que não é possível correlacionar psicopatologia à presença fissura (Clifford, 1983), o fissurado está marcado por um construto social, por um reflexo da própria cultura, que lhe cria descontinuidades ao longo de sua própria história - está marcado por um estigma.

Estigma é um conceito que nos remete aos significados de "cicatriz, marca ou sinal" (Ferreira, 1988, p.217). Através da estigmatizarão, "a sociedade estabelece meios para categorizar as pessoas... (Goffman, 1982, p.11) e as relações sociais são responsáveis pelo estabelecimento de critérios de inclusão/exclusão destas pessoas em várias circunstâncias de 
suas vidas em sociedade. E assim, qualquer alteração naquilo que é convencionado socialmente como estabelecido/esperado será alvo de estigmatização e o problema daqueles tidos como desviantes é remetido, ao nível do senso comum, à perspectiva da patologia. A ideia de estigmatização implícita ou explícita, que acompanha o indivíduo portador de uma malformação, implica necessariamente num quadro relacional, pois qualquer categoria conquistada ou atribuída não pode ser pensada isoladamente, mas no quadro do sistema de relações sociais (Goffman, 1982; Velho, 1985).

Em nosso meio, várias pesquisas acerca de crianças portadoras de fissuras lábio-palatais proporcionaram dados importantes para medidas de intervenção que permitem uma melhor compreensão de tais crianças e possibilitam trabalhar na direção de mudanças de atitude daqueles que convivem ou trabalham com elas.

Em entrevistas realizadas com setenta famílias de crianças fissuradas, ficam evidentes as cicatrizes sociais, impostas por forças de meio que buscam excluir, marginalizar essas crianças, como, por exemplo, quando a escola se recusa a receber uma menina até que ela tenha sua fissura corrigida cirurgicamente (Bauermann e Viana, 1993).

Meninas fissuradas são mais excluídas que meninos fissurados e são mais presas ao ambiente doméstico, pois tem menor número de amigos/as, podem, por determinação dos pais exercer menos atividades fora de casa e assumem mais responsabilidades por atividades domésticas, além do que é esperado em relação ao gênero feminino (Nunes e Viana, 1994).

Wiethaeuper (1993), estudando a questão da fissura pela perspectiva das percepções interpessoais e da teoria das representações sociais, obteve resultados preliminares que indicam que os próprios odontólogos são aqueles que se portam de forma mais crítica e estereotipada diante de fotos de crianças fissuradas e não fissuradas, alocando maior quantidade de adjetivos negativos às crianças fissuradas.

Muitos estudos sobre fissurados são criticados porque: a) comparam crianças fissuradas com não fissuradas; b) não separam fissurados sem evidência de psicopatologia daqueles com sinais e sintomas psicopatológicos; c) não utilizam uma teoria para analisar os dados achados. Assim, Viana (1992) projetou uma pesquisa para estudar somente fissurados, através da teoria psicanalítica, utilizando os conceitos de separação-individuação e do complexo de Édipo e excluindo da amostra casos com suspeita de retardamento mental e/ou outras psicopatologias graves. Resultados preliminares apontam para um desenvolvimento psicossocial de quarenta meninos e meninas, de 5 a 6 anos e 9 meses, conforme o previsto pela teoria para essa faixa etária. Portanto, essas crianças estão se desenvolvendo como qualquer outra criança (Viana, 1993).

No âmbito da PUCRS, o Serviço de Atendimento Integrado a Pacientes com Fissura Lábio-Palatal (SEFLAPA) da Faculdade de Odontologia e o Programa de Pós-Graduação de Psicologia do Instituto de Psicologia vêm se propondo a realizar vários trabalhos, com $\mathrm{O}$ objetivo de atendimento mais amplo dos fissurados e informação e modificação de atitudes em relação às pessoas portadoras de fissuras lábio-palatais, conforme descrição que se segue.

O Setor de Psicologia do SEFLAPA realiza psicodiagnóstico para a clientela que apresenta problemas psicológicos e encaminha para atendimento em instituições na comunidade quando um tratamento é indicado. Além disso, sempre que necessário, realiza atendimentos psicológicos na modalidade de terapia breve. Outra atividade de caráter terapêutico é a ludoterapia para preparar crianças muito ansiosas, fóbicas ou resistentes para aceitar os procedimentos médico-cirúrgicos-odontológicos.

Grupos de sala de espera oportunizam esclarecimentos e orientação para mães de crianças e adolescentes fissurados. Um grupo de sala de espera trabalha em conjunto com mães e seus filhos/as adolescentes.

Em relação a ensino e pesquisa, a produção e apresentação de resultados de pesquisa é um dos alvos principais das atividades. Uma série de trabalhos vem sendo apresentados em eventos científicos nacionais e internacionais e publicados em revistas de Odontologia e Psicologia. Foram produzidos dois trabalhos de conclusão de curso em Psicologia e uma monografia de conclusão de curso de especialização em Diagnóstico Psicológico. Estão em andamento duas dissertações de mestrado em Psicologia e uma tese de doutoramento em Odontologia com temáticas relativas a fissuras.

É estreita a relação de trabalho em equipe multidisciplinar para o atendimento dos fissurados e produção científica relativa ao tema. Fazem 
parte da equipe assistente social, psicólogos, cirurgiões-dentistas, médicos otorrino-laringologistas, e fonoaudiólogas.

O programa da disciplina de Psicologia nos cursos de pós-graduação em Odontologia foi modificado para dar mais atenção às necessidades especiais dos fissurados.

O SEFLAPA é local de pesquisa para diversas atividades do curso de Psicologia, como, por exemplo, trabalhos especiais das disciplinas de Psicologia Social e de Psicologia do Desenvolvimento, bem como trabalhos de bolsistas de iniciação científica.

Está em fase de produção um livro que reúne diversas pesquisas realizadas em nosso meio sobre fissurados, tendo como público-alvo, principalmente, estudantes e profissionais de Odontologia e Psicologia. Um folheto de esclarecimentos e orientação sobre fissuras está em planejamento para atender às perguntas que pais de fissurados constantemente formulam aos profissionais que atendem suas crianças no SEFLAPA.

Com tais atividades, pensamos contribuir para esclarecer e orientar sobre aspectos psicossociais do portador de fissuras a dois grupos de pessoas que estão mais próximas dos fissurados: estudantes e profissionais de Odontologia e de Psicologia e familiares. Estas são pessoas que, tanto quanto muitas outras, são pressionadas pela fórmula beleza/perfeição imposta por nossa sociedade centrada na corpolatria.

\section{Referências Bibliográficas}

AMARAL, V.L.A.R. (1986). Vivendo com uma face atípica: influência da deformidade facial, no auto e hetero conceitos e na realização acadêmica de crianças de 6 a 12 anos. São Paulo. Tese de Doutoramento em Psicologia. Instituto de Psicologia USP.

BAUERMARM, N. \& Viana, M.L. (1993). Cicatrizes sociais da família da criança fissurada. XXIV Congresso Interamericano de Psicologia. Santiago, Chile.

BORGES-OSÓRIO, M. R. \& Robinson, W. M. (1993). Genética Humana. Porto Alegre: Artes Médicas.
CARIOLA, T. C. \& Ferreira de Sá, A. E. (1987). Aspectos comparativos entre crianças "normais" e crianças portadoras de fissuras lábiopalatais através dos indicadores emocionais de Koppitz no desenho da figura humana. Pediatria Moderna, v.22, n.9, p.308-326.

CLIFFORD, E. (1983). Why are they so normal? Cleft palate J., v. 20, p.8383.

ELY, J.F. (1980). Cirurgia Plástica. Rio de Janeiro: Guanabara-Koogan.

FERREIRA, A.B. de H. (1988). Novo Dicionário da Língua Portuguesa. Rio de Janeiro: Nova Fronteira.

GOFFMAN, I. (1982). Estigma: notas sobre a manipulação da identidade deteriorada. Rio de Janeiro: Zahar.

HACKLÖER, J. F. (1984). Ultraschall. In: JW. Dudenhausen. (Hrsg.). Praxis der perinatal Medizin. Stuttgart: Klett.

HOPKER, W.W. (1984). Interpretationen, Assoziationen und diagnostische Validitäit. Berlin: Fisher.

KLAUS, M.H. \& Kennell, J.H. (1978). La relación madre-hijo. Buenos Aires: Panamericana.

MCWILLIAMS, B.J. (1982). Social and psychological problems associated with cleft palate. Clin. Plast. Surg., v. 9, p. 317-325.

MERCER, R. T. (1974). Mothers 'responses to their infants' defects. Nurs. Res., v. 23, p. 133-137.

NUNES, M.L.T. \& Viana, M.L. (1994). Social exclusion: effect of malformation, gender and income. 23rd International Congress of Applied Psychology. Madrid, Spain.

RAUSKOLB, R. (1984). Fetoskopie. In: J. W. Dudenhausen. (Hrsg.). Praxis der perinatal Medizin. Stuttgart: Klett.

RESENDE, J.H.C. (1983). 1000 perguntas em cirurgia plástica. Rio de Janeiro: Editora Rio.

SOLNIT, A.J. \& Stark, M H.(1962). Mourning and birth of a defective child. The Psychoanalytical Study of the Child. v. 16, p.523-537. 
TISZA, V. B. \& Gumpertz, E. (1962). The parent's reaction to the birth and early care of children with cleft palate. Pediatrics. v. 20, p.86-90.

TUREEN, P. \& Tureen, J. (1986). Childhood speech and language disorders. In: R. T. Brown \& C. E. Reynolds. (Eds.). Psychological perspectives on childhood exceptionality. New York: Basic Books.

VELHO, G. (1985). Desvio e divergência: uma crítica da patologia social. Rio de Janeiro: Zahar.

VIANA, M. L. (1992). Desenvolvimento psicossocial da criança préescolar com malformação congênita, em diferentes níveis sociais. Porto Alegre. Projeto de Dissertação de Mestrado em Psicologia Social e da Personalidade, Instituto de Psicologia, PUCRS.

VIANA, M. L. (1993) Aspectos psicossociais do portador de fissura lábiopalatal. Relatório de Pesquisa, Instituto de Psicologia, PUCRS.

VIANA, M. L.; Giacomoni, C. \& Rashid, L. (1994). O que fiz por merecer? Aspectos psicológicos da relação mãe-bebê malformado. Psico, v. 25, p. 91-99.

WIETHAEUPER, D. (1993). Atratividade física facial e estigmatização de fissurados. Relatório de Pesquisa em Psicologia, Instituto de Psicologia, PUCRS.

WOLKIND, S. (1983). Pre-natal emotional stress-effect on the foetus. In: S. Wolkind \& E. Zajicek. (Bis.) Pregnancy: a Psychological and Social Study. London: Routledge. 